$\begin{array}{ll}\text { Reference } & \begin{array}{l}\text { NBS } \\ \text { Pubil- } \\ \text { cations }\end{array}\end{array}$

NBSIR 80-1961

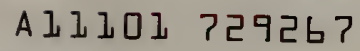

\begin{tabular}{l} 
Simplified Heating and Cooling \\
Energy Analysis Calculations for \\
Residential Applications \\
\hline
\end{tabular}

Tamami Kusuda

T. Saitoh

National Bureau of Standards

National Engineering Laboratory

Center for Building Technology

U.S. Department of Commerce

Washington, DC 20234

Sponsored by

U.S. DEPARTMENT OF ENERGY

Office of Building and Community Systems

Washington, D.C. 20585

July 1980

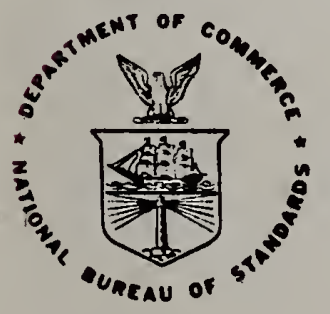

U.S. DEPARTMENT OF COMMERCE

NATIONAL BUREAU OF STANDARDS

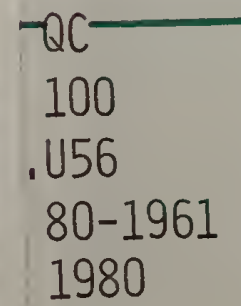





\section{Simplified Heating and Cooling Energy Analysis Calculations for Residential Applications}

Tamami Kusuda

T. Saitoh

National Bureau of Standards National Engineering Laboratory Center for Building Technology U.S. Department of Commerce Washington, DC 20234

Sponsored by

U.S. DEPARTMENT OF ENERGY

Office of Building and Community Systems

Washington, D.C. 20585

July 1980

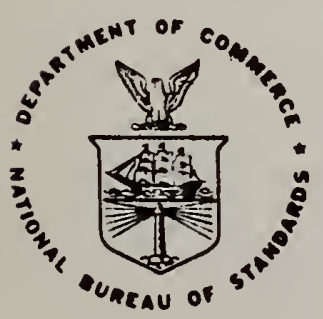

U.S. DEPARTMENT OF COMMERCE

NATIONAL BUREAU OF STANDARDS 



\section{SIMPLIFIED HEATING AND COOLING \\ ENERGY ANALYSIS CALCULATIONS FOR \\ RESIDENTIAL APPLICATIONS}

Tamami Kusuda

T. Saitoh

National Bureau of Standards

National Engineering Laboratory

Center for Building Technology

U.S. Department of Commerce

Washington, DC 20234

July 1980

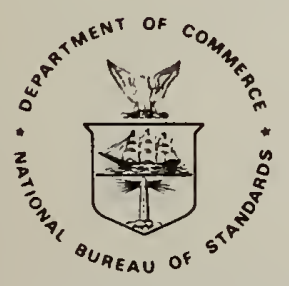

U.S. DEPARTMENT OF COMMERCE, Philip M. Klutznick, Secretary Luther H. Hodges, Jr., Deputy Secretary Jordan J. Baruch, Assistant Secretary for Productivity. Technology. and Innovation NATIONAL BUREAU OF STANDARDS, Ernest Ambler, Director 


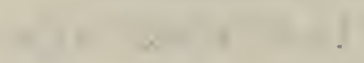

$+$ 


\title{
Simplified Heating and Cooling Energy Analysis \\ Calculation for Residential Applications
}

\author{
T. Kusuda and T. Saitoh* \\ Center for Building Technology \\ National Engineering Laboratory \\ National Bureau of Standards \\ Washington, D.C. 20234
}

\begin{abstract}
In order to reduce the lengthy computational labor and costs common to most existing hourly simulation computer programs, a simplified energy calculation procedure suitable for a handheld calculator was developed for the evaluation of home retrofitting with respect to energy conservation. The procedure utilizes monthly normal weather parameters such as temperature, humidity, wind data, and solar radiation, in lieu of the traditional degree-day procedure.
\end{abstract}

The thermal time constant was used to account for the effect of building thermal mass on seasonal heat transfer performance. In addition to standard retrofit procedures such as addition of thermal insulation, use of storm windows, and sealing of cracks, this calculation includes energy conservation effect due to the use of solar collectors, hot water tank insulation, and insulation around the heat distribution systems such as ducts and pipes.

Also included are comparative annual heating and cooling requirements determined by the simplified procedure and that calculated by the DOE-2 computer program for a typical residence.

Keywords: Energy analysis calculation; energy retrofit; home audit; thermal time constant.

* Guest worker from Ohbayashi-Gumi, Tokyo, Japan. 


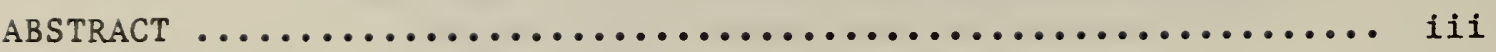

1. INTRODUCTION ................................. 1

2. OVERALL ALGORITHMIC STRUCTURE $\ldots \ldots \ldots \ldots \ldots \ldots \ldots \ldots \ldots \ldots \ldots \ldots \ldots \ldots$

3. THERMAL TIME CONSTANT, THTC ...................... 4

4. ENVELOPE DATA ................................ 4

4.1 Type Designation ............................. 4

4.2 Area, A ........................................ 4

4.3 Overall Heat Transfer Coefficient U ................ 4

4.4 Solar Absorptivity, ABS ....................... 6

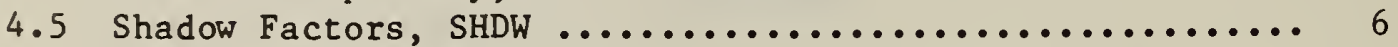

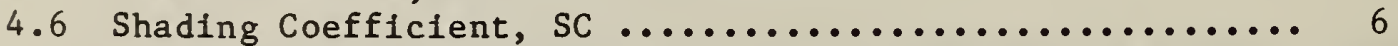

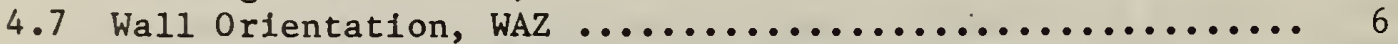

4.8 Wall Tilt Angle, WTLT ......................... 6

5. SUBROUTINE ALGORITHMS $\ldots \ldots \ldots \ldots \ldots \ldots \ldots \ldots \ldots \ldots \ldots \ldots \ldots \ldots \ldots \ldots . \ldots \ldots$

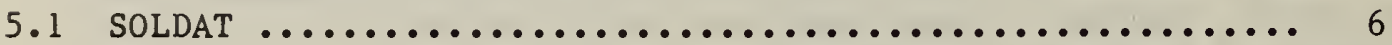

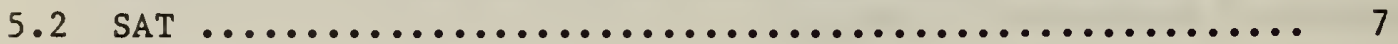

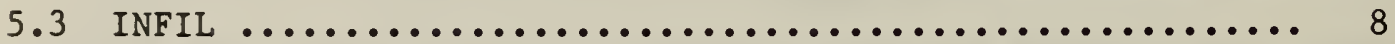

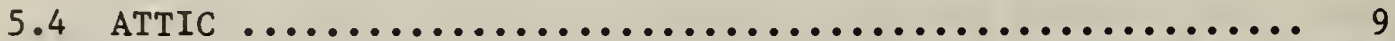

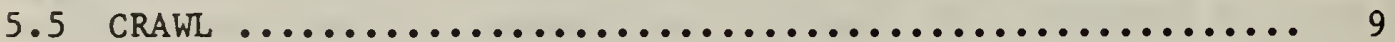

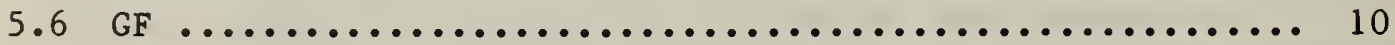

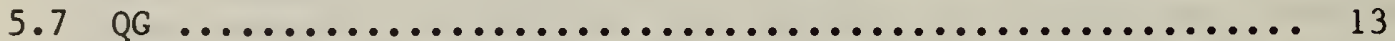

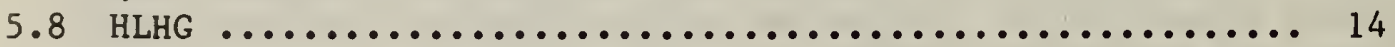

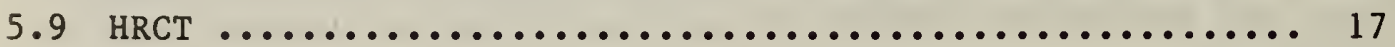

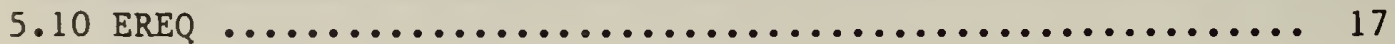

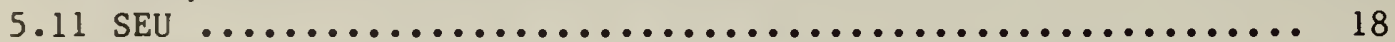

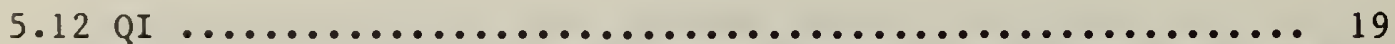

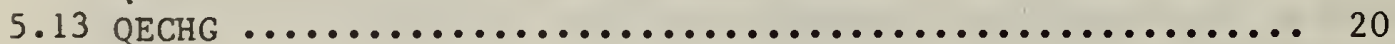

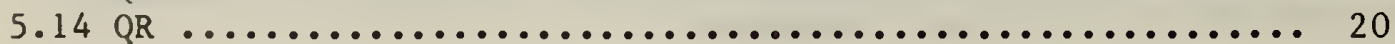

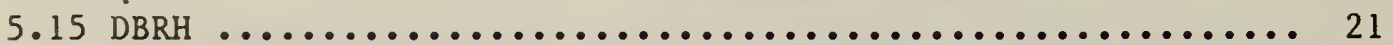

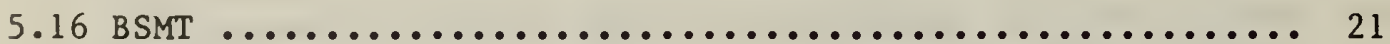

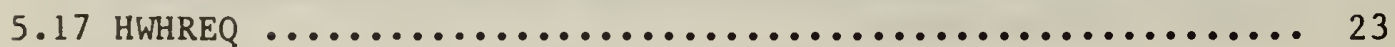

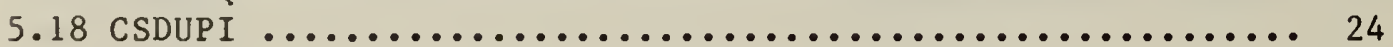

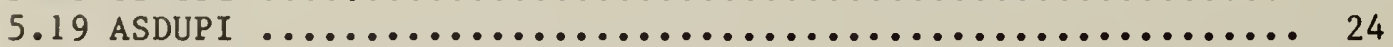

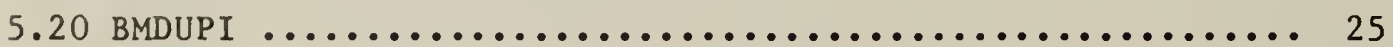

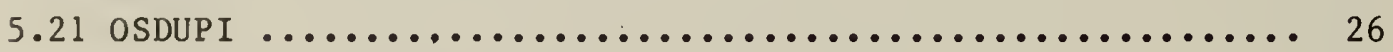

6. COMPARISON WITH DOE-2 RUNS $\ldots \ldots \ldots \ldots \ldots \ldots \ldots \ldots \ldots \ldots \ldots \ldots \ldots \ldots$

APPENDIX A: LIU-JORDAN SOLAR CALCULATION DATA .............. A-1 APPENDIX B: AVERAGE EARTH TEMPERATURE FOR UNDERGROUND HEAT

DISTRIBUTION SYSTEM ........................ B-1

APPENDIX $C$ : FORTRAN LISTING OF THE COMPUTER PROGRAM $\ldots \ldots \ldots \ldots \ldots . . .$. APPENDIX D: ELEMENTS OF DATA STATEMENT IN MAIN PROGRAM $\ldots \ldots \ldots \ldots . . .1$ APPENDIX E: THERMAL TIME CONSTANT AND ITS APPLICATION $\ldots \ldots \ldots \ldots . .$. E- 


\section{INTRODUCTION}

The purpose of this report is to describe detalled algorithm, data base and Fortran listing of a simplified home energy analysis procedure suitable for small computer or pocket calculator. This simplified procedure was originally developed for DOE to assist the state and local government energy officials who are making economic benefit analyses of various home improvement options, such as insulation, storm windows, hot water tank insulation, insulation around pipes and ducts, etc.

The procedure calculates the annual energy requirement calculations for heating and cooling of single-family residences in conjunction with the Department of Energy Project Home Energy Audit questionnaire and economic analysis. Since the Project Home Energy Audit Program mandated that the computation time, equivalent to the UNIVAC $1100 \mathrm{CPU}$ (Central Processing Unit) time, is to be within 3 seconds, it precluded the comprehensive hourly simulation procedures such as used in BLAST, DOE-2, and NBSLD.

A scheme adopted in the DoE Home Energy Audit calculation procedure is to develop a simplified yet relatively comprehensive heating and cooling load calculation routine where most of the major building heat transfer elements are addressed in an approximate manner. The results of the calculation obtaiked by this simplified routine are then compared against those obtained from a DOE- 2,27 the comprehensive hourly simulation computer program designated as the Standard Evaluation Technique for Building Energy Performance Standards, for a ranch house.

\section{OVERALL ALGORITHMIC STRUCTURE}

The flow chart for the simplified procedure is shown in Figure 1 , and detailed algorithms, including Fortran listing, for each of the subroutines are given in the following sections.

The basic scheme of the calculation is to detemine monthly normal values of daytime and nighttime heat gains (heat loss will be considered a negative heat gain) separately for all of the major heat exchange components, and to integrate them into monthly normal daytime and nighttime heating and cooling requirements.

In Figure 1, all of the major heat gain (loss) through various elements of building envelope is denoted with symbols ending with $D$ and $N$, indicating daytime heat gain and nighttime heat gain, respectively.

Although not described in detail in this report, a special subroutine, SOLDAT, was developed to generate daily total solar radiation data for the normal day for each of 12 months for any given orientation and tilt angle of the wall in a given locality, while a separate routine called SAT determines the normal daily average sol-air temperature to be applicable for the calculation of heat gain through walls, roofs, and doors. Detailed documentation for SOLDAT can be found in reference 2 . 


\section{NBS HOME ENERGY AUDIT CALCULATION}

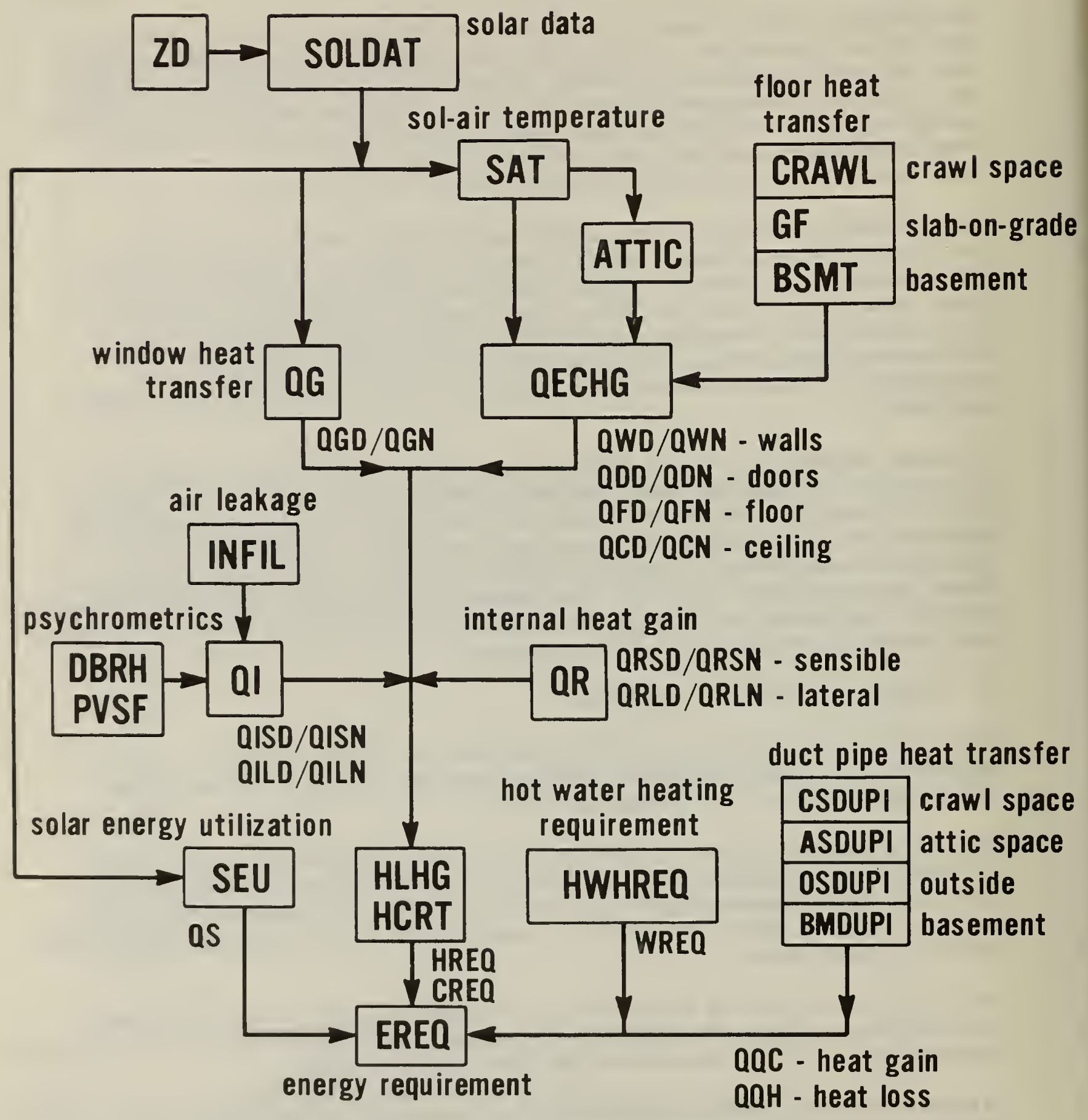


Where the roof has ventilated attic space, the program determines the attic space temperature based upon heat balance, which is in turn used to determine the heat gain through the ceiling.

The SOLDAT routine will also provide the solar radiation data for the solar collectors, which may be available in some of the eneryy conservation designs. The solar collector performance will be simulated by a simplified linear relationship between the collector efficiency and $\Delta \mathrm{T} / \mathrm{I}$, where $\Delta \mathrm{T}$ represents the average temperature difference between the outdoor air and collector inlet fluid temperatures, while I represents the dafly average of hourly solar insolation.

Heat gain from the floors is determined by the use of special algorithms to simulate the heat transfer process of basement, slab-on-grade, and crawl space under the floor, respectively.

In addition, there are several other subroutines in the calculation, such as INFIL to determine the air leakage rate, DBRH to determine the moist air properties, and subroutines to determine the energy loss from hot water tanks, ducts and pipes.

The major distinction of the present method from the existing degree-day or bin procedures is that the new method is based upon the monthly normal day data for each of the 12 months of the year. The monthly normal data needed are:
daytime average temperature nighttime average temperature total solar radiation upon horizontal surface average relative humidity (morning and afternoon) average wind speed ground temperature

for the normal days of the month.

Fortunately, these data are available in the existing literature for most of the major Weather Bureau stations throughout the United States. The Liu and Jordan paper, entitled, "Availability of Solar Energy for Flat-Plate Solar Collectors," ASHRAE Symposium on Low Temperature Engineering Applications of Solar Energy, 1967, provides the average daytime temperature and the solar radiation data for more than 80 stations in the United States (see Appendix A). A U.S. Weather Bureau publication called "Comparative Climatic Data Through 1976"* provides the long-period (30 years or more) normals and extremes of monthly average temperature, precipitation, relative humidity, and wind data.

Ground temperature data, previously developed by Kusuda and Achenbach, shown in Appendix B, are also employed for the heat transfer calculation for slab-on-grade floor, basement walls and basement floor.

‡ For sale by the National Climatic Center, Federal Bldg., Asheville, N.C., 28801 ( $\mathrm{Tel}$. 704-258-2850, X 683). \$1.50 copy. 


\section{THERMAL TIME CONSTANT, THTC}

Although the calculation methodology used in this procedure basically treats the building heat transfer process as a steady state problem, the thermal time constant concept is used to determine the heat capacity effect upon the transient temperature change after the heating and cooling system is shut off as well as upon the early morning hour pickup load when the system is started. Details of the thermal time constant concept are explained in Appendix E.

\section{ENVELOPE DATA}

Figure 2 indicates various types of physical characteristics needed to describe the thermal performance of various components of envelopes, most of which are commonly found in standard engineering building handbooks such as the ASHRAE Handbook of Fundamentals.

\subsection{TYPE DESIGNATION}

Envelope components, including the solar collector, are classified in eleven distinctive types such as follows:

Type No.

1. roof $=$ total roof area less solar collector and skylight

2. ceiling

3. end walls or gable walls of attic space

4. vertical walls, which are vertical envelopes less window and door area

5. windows

6. doors

7. slab-on-grade floor

8. basement-type floor

9. floor over crawl space

10. basement wall

11. solar collector.

\subsection{AREA, A}

Each envelope component must be assigned an appropriate area. Futhermore, this must be done separately for each wall orientation (see section 4.7) The orientation effects on gable-end walls and basement walls are ignored, and only the total area is to be considered. If a door is made of transparent material, it should be considered as a window.

\subsection{OVERALL HEAT TRANSFER COEFFICIENT U}

Overall heat transfer coefficients are to be provided as input for each envelope component. They are standard winter design values which can be found in the ASHRAE Handbook of Fundementals. In the case of solar collectors no heat transfer coefficient $U$ is needed since it is included in the basic efficiency curve data. 


\section{$\overline{B U} \overline{I L D I N G} \overline{N A M E}$ \\ $\overline{\text { TYPE }}$ \\ LOCATION, LATITUDE, ZIPCOUE ZONE}

Climatic Data (Monthly)

TOT: Daily average temp

TOD: Daytime average temp

RH: Relative humidity

WS: Wind speed

H: Dally total horizontal solar insolation

2T: Liu/Jordan Factor

RHO: Ground surface reflectance
Standard Air Leakage Lata ACHS: Room air change/hr

ACAT: Attic space air change/hr

ACCS: Crawl space air change/hr

ACNV: Natural ventilation air challos/thr

Building Mass Vata

THTC: Thernal Time Constant

\begin{tabular}{|c|c|c|c|c|c|c|c|c|c|}
\hline Envelope Nata & $\begin{array}{c}1 \\
\text { Type }\end{array}$ & $\begin{array}{c}\text { A } \\
\text { Area }\end{array}$ & $\mathbf{U}$ & $\begin{array}{l}\text { Ab } \\
\text { Solar }\end{array}$ & $\begin{array}{l}\text { SHUW } \\
\text { Shadow }\end{array}$ & $\begin{array}{c}\text { SC } \\
\text { Shading }\end{array}$ & $\begin{array}{c}\text { WAZ } \\
\text { Orien- }\end{array}$ & WTLT & Perimeter \\
\hline
\end{tabular}

\begin{tabular}{llll} 
Koof & 1 & 0 \\
\hline Ceiling & 2 & 90 \\
\hline Att1c End Walls & 3 & 90 \\
\hline & 1 & 4 & 90 \\
& 2 & 4 & 90 \\
Walls & 3 & 4 & 90 \\
& 4 & 4 & 9
\end{tabular}

\begin{tabular}{llll} 
& 1 & 5 & 90 \\
Windows & 2 & 5 & 90 \\
& 3 & 5 & 90 \\
& 4 & 5 & 90 \\
\hline
\end{tabular}

Doors $(4$

6

90

sides)

\begin{tabular}{ll} 
Slab on Grade & 7 \\
\hline Basement & 8 \\
\hline Crawl Space & 9
\end{tabular}

Basement Wall $\quad 10$

Solar Collector 11

0

Equipment Data (Seasonal average)

EG: Gas furnance efficiency

EB : Boiler efficiency

COP: Air conditioner COP

$\mathrm{SA}, \mathrm{SB}$ : Solar collector

efficiency factors

90

90

90

90

0

O

$\begin{array}{r}90 \\ \hline\end{array}$

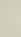




\subsection{SOLAR ABSORPTIVITY, ABS}

These data are used to determine the outside surface temperature of exterior walls as influenced by the solar radiation data. Typical values are:

$$
\begin{array}{ll}
\text { for very dark surface } & 0.95 \\
\text { medium dark surface } & 0.7 \\
\text { light surface } & 0.4
\end{array}
$$

\subsection{SHADOW FACTORS, SHDW}

This factor indicates how much of the exterior surface is shaded from direct sun by adjacent buildings, exterior shading devices, or by trees. Typical figures are:

$$
\begin{array}{ll}
\text { if completely shaded } & 1.0 \\
\text { if partially shaded } & 0.5 \\
\text { if not shaded at all } & 0 .
\end{array}
$$

\subsection{SHADING COEFFICIENT, SC}

This factor relates to the internal shading devices used for the windows. Typical values for a single glaze window are:

$$
\begin{array}{cc}
\text { for venetian blinds } & 0.5 \\
\text { roller shades } & 0.4 \\
\text { tinted films } & 0.3 .
\end{array}
$$

\subsection{WALL ORIENTATION, WAZ}

These data indicate the orientation of walls and windows, measured clockwise from the south. Thus, for example,

$$
\begin{aligned}
& \text { WAZ }=0 \text { for south-facing wall/window/door } \\
& W A Z=90 \text { for west } \\
& W A Z=180 \text { for north } \\
& W A Z=270 \text { for east. }
\end{aligned}
$$

\subsection{WALL TILT ANGLE, WTLT}

These data are for the slant angle of the walls or windows. For most construction, the value is $90^{\circ}$ for walls and windows and $0^{\circ}$ for roofs. For solar collectors, the actual tilt angle will be used and will usually be an angle other than $0^{\circ}$ or $90^{\circ}$.

\section{SUBROUTINE ALGORITHMS}

\subsection{SOLDAT}

Using the Liu/Jordan method 2/, this program generates 12 monthly values of total solar radiation over the roofs, floors, walls, windows, and solar 
collectors. The details of the calculation procedure are given in NBS Building Sciences Series 96 entitled "Hourly Solar Radiation Data for Vertical and Horizontal Surfaces on Average Days in the United States and Canada." This routine also includes the shadow effect of the roof overhang upon the direct radiation incident on a given vertical surface.

Input: $\quad \mathrm{XLAT}=$ latitude, degree

$\mathrm{WAZ}=$ wall azlmuth angle, degrees from south

WTLT = wall tilt angle, degree from horizontal surface

$\mathrm{ZKT}=\mathrm{Liu} / \mathrm{Jordan}$ constants $\begin{aligned} \mathrm{H}= & \text { daily normal solar radiation over a horizontal } \\ & \text { surface } \mathrm{Btu} / \mathrm{ft}^{2}\end{aligned}$

$\mathrm{RHO}=$ ground reflectance

TOWN $=$ zip code

OVHANG = roof overhang, $\mathrm{ft}$

WALLHT $=$ wall height, $\mathrm{ft}$

Output: XIDT = dally total solar radiation, Btu/hr $\mathrm{ft}^{2}$

$X I D D=$ dally total diffuse sky radiation, Btu/hr $\mathrm{ft}^{2}$

HRDAY = daytime hours, hr

HRNIT = nighttime hours, hr

\subsection{SAT}

Sol-air temperature routine

Input: $\quad$ WTLT $=$ tilt angle, degrees from horizontal surface

It = incident total solar insolation, Btu/day $\mathrm{ft}^{2}$

Id = incident sky Tadiation, Btu/day $\mathrm{ft}^{2}$

SHDW = shadow factor

0 = no shadow

$0.5=$ partial shadow

1.0 = complete show

$\mathrm{AB} \quad=$ surface absorptivity

FO = surface heat transfer coefficient, Btu/h $\mathrm{ft}^{2}{ }^{\circ} \mathrm{F}$

$=4$ for $\mathrm{J}, \mathrm{J}, \mathrm{A}$

$=5$ for $M, A, M, S, O, N$

$=6$ for $\mathrm{D}, \mathrm{J}, \mathrm{F}$

TOD = daytime temperature, ${ }^{\circ} \mathrm{F}$

TON = nighttime temperature, ${ }^{\circ} \mathrm{F}$

HRDAY = daytime hours, hr

Total radiation incident upon a surface

$\mathrm{I}=(\mathrm{It}-\mathrm{Id}) *(1-\mathrm{SHDW})+\mathrm{Id}$

Output: Sol-a1r temperature

Daytime $\quad \mathrm{SATD}=\mathrm{TOD}+\frac{\mathrm{AB} * \mathrm{I}}{\mathrm{HRDAY} * \mathrm{FO}} \quad \frac{10 * /}{\mathrm{FO}} * \cos$ (WTLT) 


$$
\text { N1ghttime SATN }=\text { TON }-\frac{10^{\star} /}{\text { FO }} * \cos (\text { WTLT })
$$

\subsection{INFIL}

Infiltration calculation, $\mathrm{cfm}$

$$
\begin{aligned}
& \text { Input: } \mathrm{V} \quad=\text { volume of the room, } \mathrm{ft}^{3} \\
& \text { ACHS = standard air change data, air change/hr } \\
& \text { TO = outdoor temperature, }{ }^{\circ} \mathrm{F}=(\mathrm{TOD}+\mathrm{TON}) / 2 \\
& \text { TI = indoor temperture, }{ }^{\circ} \mathrm{F}=(\mathrm{TID}+\mathrm{TIN}) / 2 \\
& \text { WS = wind speed, } \mathrm{mph} \\
& \text { AC }(\text { air leakage rate })=(\text { ACHS } / 0.695) *[0.15+0.013 * \text { WS } \\
& +0.005 * \mathrm{ABS}(\mathrm{TO}-\mathrm{TI})]^{ \pm 1}
\end{aligned}
$$

\section{Standard Air Leakage Data (ACHS)}

In lieu of the crack method, hourly air-change values are to be provided because there are more experimentally measured data reported by the use of He and $\mathrm{SF}_{6}$ tracer gas dilution technique. Recommended values are as follows:

Living space: 1.5 for leaky bullding

1.0 for standard building

0.5 for modern-type bullding

Attic space: mechanical ventilation $20 \mathrm{Ac} / \mathrm{hr}$ natural ventilation $6 \mathrm{Ac} / \mathrm{hr}$

Crawl space:

$3 \mathrm{Ac} / \mathrm{hr}$

Output: Air leakage rate

$$
\operatorname{RINFIL}=(V) * \frac{\mathrm{AC}}{60}, \mathrm{ft}^{3} / \mathrm{m}(\mathrm{cfm})
$$

*/ Assumed average sky heat 108s: $10 \mathrm{Btu} / \mathrm{hr}, \mathrm{ft}^{2}$.

$\pm /$ Modified Achenbach/Coblenz equation.

"Field Measurements of Air Infiltration in Ten Electrically Heated Houses" ASHRAE Trans. 69, 1963, pp. 358-365.

DOE - 2 program uses, however, different equations such as $\mathrm{AC}=0.252+0.0218$ * WS $+0.0084 * \mathrm{ABS}(\mathrm{TO}-\mathrm{TS})$ 


\subsection{ATTIC}

Attic temperature calculation

Input:

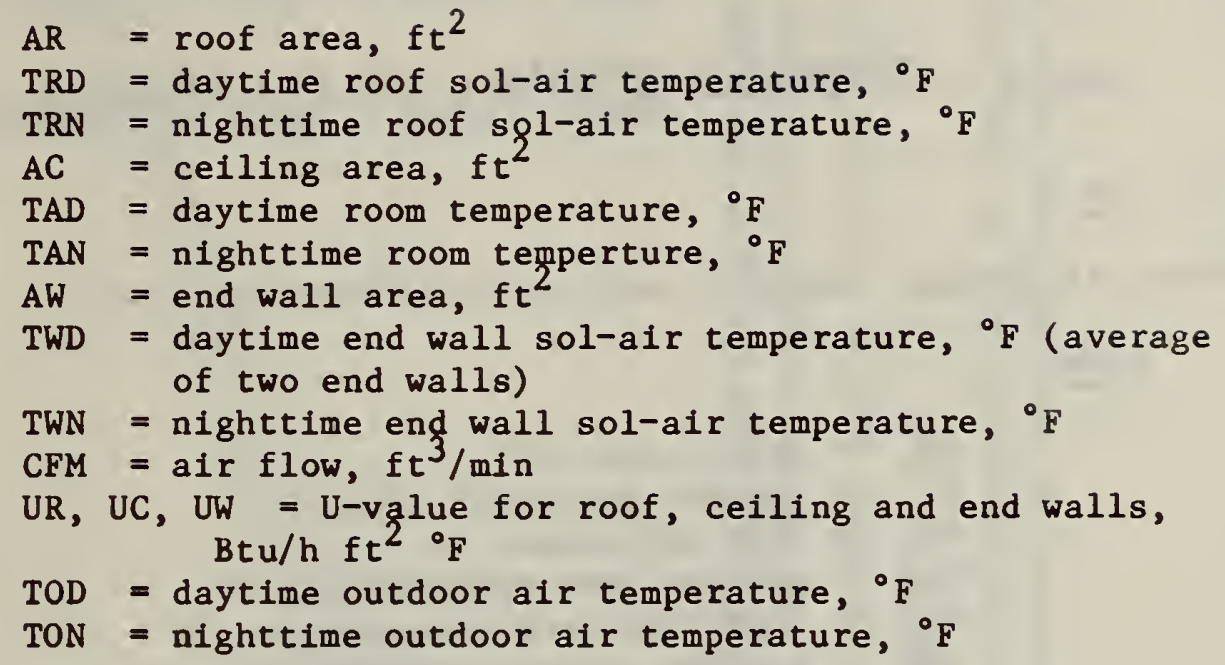

Output: Attic temperature (daytime and nighttime)

$A T T I C D=\frac{U{ }^{*} A R^{*} T R D+U W^{*} A W^{*} T W D+U C * A C * T A D+1.08 * C F M * T O D}{U R^{\star} A R+U W^{\star} A W+U C^{\star} A C+1.08 * C F M}$

$\operatorname{ATTICN}=\frac{U R * A R * T R N+U W * A W * T W N+U C * A C * T A N+1.08 * C F M * T O N}{U R * A R+U W^{*} A W+U C * A C+1.08 * C F M}$

ATTICD = TID if attic temperature is controlled

ATTICN $=$ TIN

5.5. CRAWL

Crawl space temperature routine

Input: Daytime and nighttime crawl space temperatures

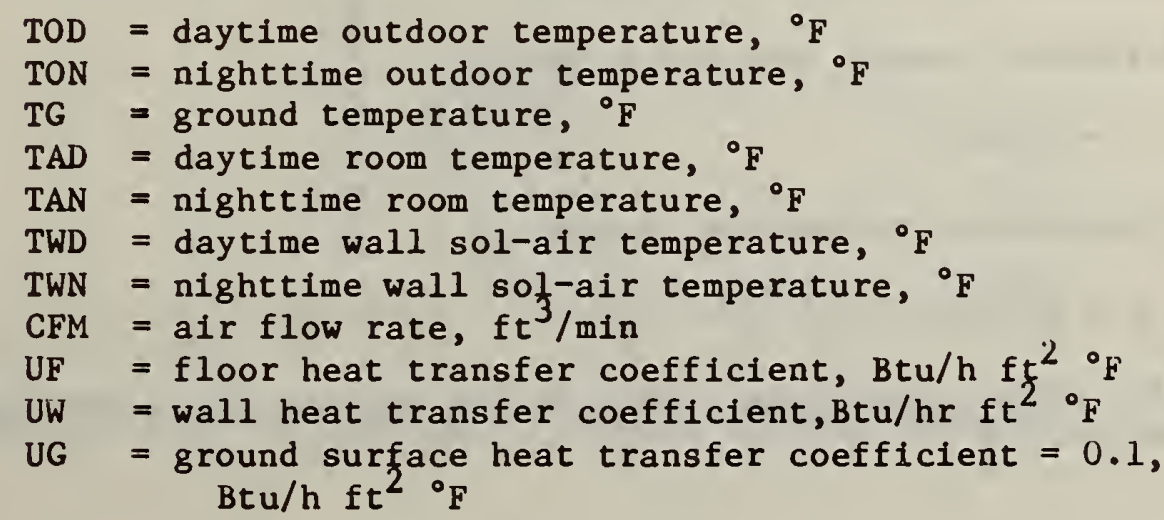




$$
\begin{aligned}
& \mathrm{AW}=\text { crawl space wall area, } \mathrm{ft}^{2} \\
& \mathrm{AF}=\text { floor area, } \mathrm{ft}^{2}
\end{aligned}
$$

Output:

$$
\begin{aligned}
& \text { CRAWLN }=\frac{U F * T A D * A F+U W * T W D * A W+U G *(T G+T O D) * A F / 2+1.08 * C F M * T O D}{U F * A F+U W * A W+U G * A F+1.08 * C F M} \\
& \mathrm{CRAWLN}=\frac{\mathrm{UF} * \mathrm{TAN} * \mathrm{AF}+\mathrm{UW}{ }^{*} \mathrm{TWN} * \mathrm{AW}+\mathrm{UG} *(\mathrm{TG}+\mathrm{TON}) * \mathrm{AF} / 2+1.08 * \mathrm{CFM}{ }^{*} \mathrm{TON}}{\mathrm{UF}{ }^{*} \mathrm{AF}+\mathrm{UW}{ }^{*} \mathrm{AW}+\mathrm{UG}{ }^{*} \mathrm{AF}+1.08 * \mathrm{CFM}}
\end{aligned}
$$

5.6. $\underline{\text { GF }}$

Ground floor heat transfer routine (slab-on-grade floor)

Input:

$$
\begin{aligned}
\mathrm{AF} & =\mathrm{floor} \text { area, } \mathrm{ft}^{2} \\
\mathrm{P} & =\text { exposed perimeter length, } \mathrm{ft} \\
\mathrm{WT} & =\text { wall thickness, ft } \\
\mathrm{TAD}= & \text { daytime room temperature, }{ }^{\circ} \mathrm{F} \\
\mathrm{TAN}= & \text { nighttime room temperature, }{ }^{\circ} \mathrm{F} \\
\mathrm{TOD}= & \text { daytime outdoor temperature, }{ }^{\circ} \mathrm{F} \\
\mathrm{TON}= & \text { nighttime outdoor temperature, }{ }^{\circ} \mathrm{F} \\
\mathrm{R}= & \text { Thermal resistance of hour layers, which is between } \\
& \text { the room air and the floor slab-ground } \text { flnterface, }^{2} \\
\mathrm{ZK}= & \text { Ground thermal conductivity Btu-in/h } \mathrm{ft}{ }^{\circ} \mathrm{F}
\end{aligned}
$$

\section{Calculation Procedure}

The slab-on-grade heat transfer calculation presented herein is based upon an exact solution of Muncey and Spencer ${ }^{3}$.

The Base Ground Thermal Resistance RS shown in Fig. 3 was precalculated for a square slab of $40 \mathrm{ft} \times 40 \mathrm{ft}$ over a ground of thermal conductivity $12 \mathrm{Btu}-\mathrm{in} / \mathrm{h} \mathrm{ft}{ }^{\circ} \mathrm{F}$.

In order to correct the value of RS for the specific slab under consideration, which would be different from the basic structure, the three correction factors $\alpha, \beta$ and FS are needed.

The Perimeter length correction factor

$$
\alpha=P / 160
$$

The Conductivity correction factor

$$
B=2 \mathrm{~K} / 12
$$

The slab shape correction factor FS can be determined from Fig. 4 by knowing $\mathrm{AF} / \mathrm{P}_{4}^{2}$ 


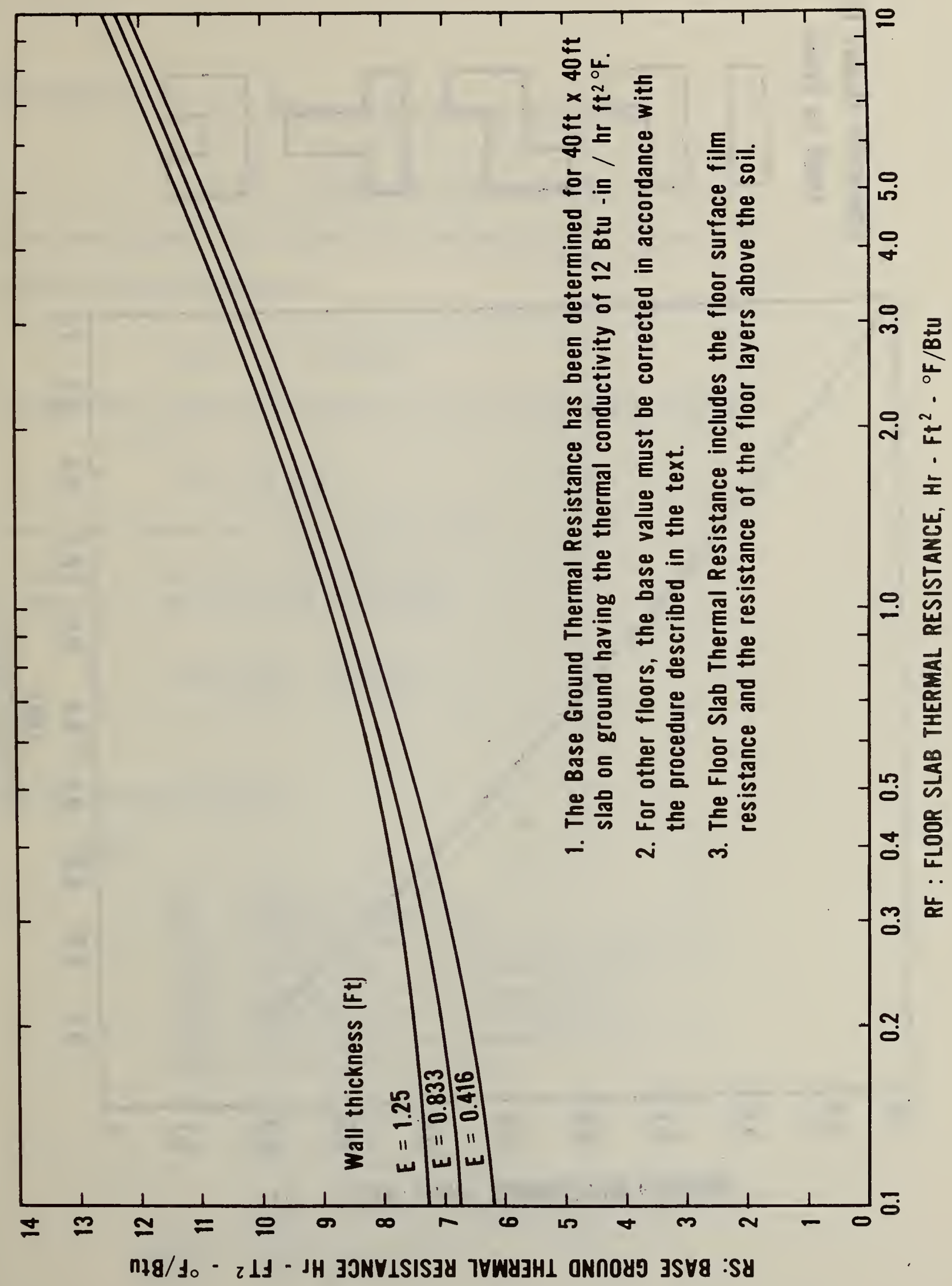

Figure 3. Thermal resistance of slab-on-grade floor. 

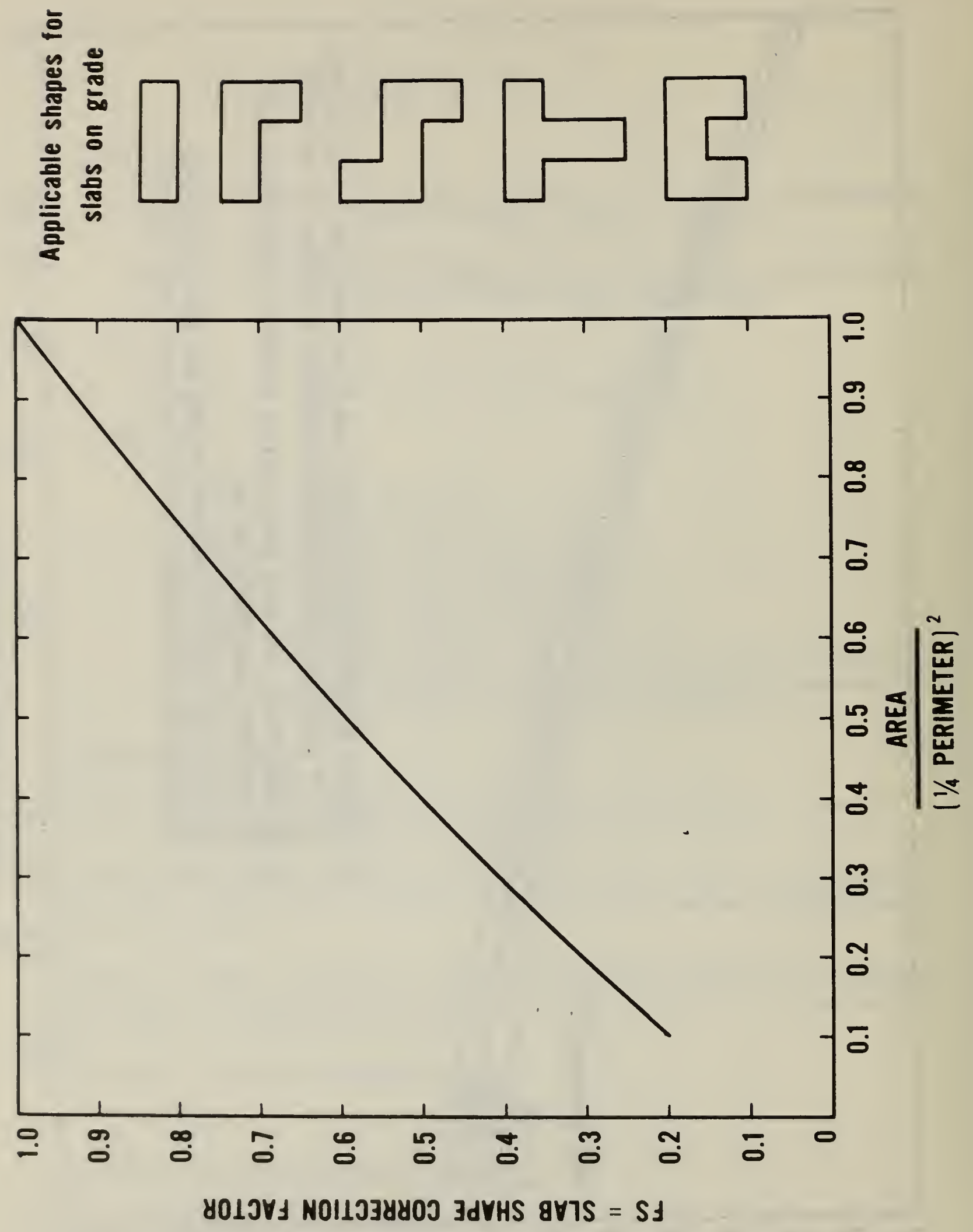

Figure 4. Shape correction factor for the slab-on-grade floor. 
Calculation

$$
\begin{aligned}
& R F=\frac{\beta}{\left(\alpha^{\star} U F\right)}: \text { adjusted floor resistance } \\
& E=\frac{W T}{\alpha} \quad \text { adjusted wall thickness }
\end{aligned}
$$

Read from Figure 2 the value of RS corresponding to these KF and E data.

Ground Thermal Resistance:

$$
\mathrm{RG}=\frac{\alpha}{B} \star \mathrm{RS} * \mathrm{FS}
$$

Overall heat transfer coefficient of the slab-on-grade floor:

$$
\mathrm{UF}=\frac{1}{(\mathrm{RG}+\mathrm{R})}
$$

Heat loss through the slab-on-grade floor:

daytime: $\quad \mathrm{QFD}=\mathrm{UF} * \mathrm{AF} *(\mathrm{TAD}-\mathrm{TO})$

nighttimes: $\quad \mathrm{QFN}=\mathrm{UF} * \mathrm{AF} *(\mathrm{TAN}-\mathrm{TO})$

$$
\text { where TO }=\frac{\text { TOD+TON }}{2}
$$

\subsection{QG}

Window heat gain routine

Input:

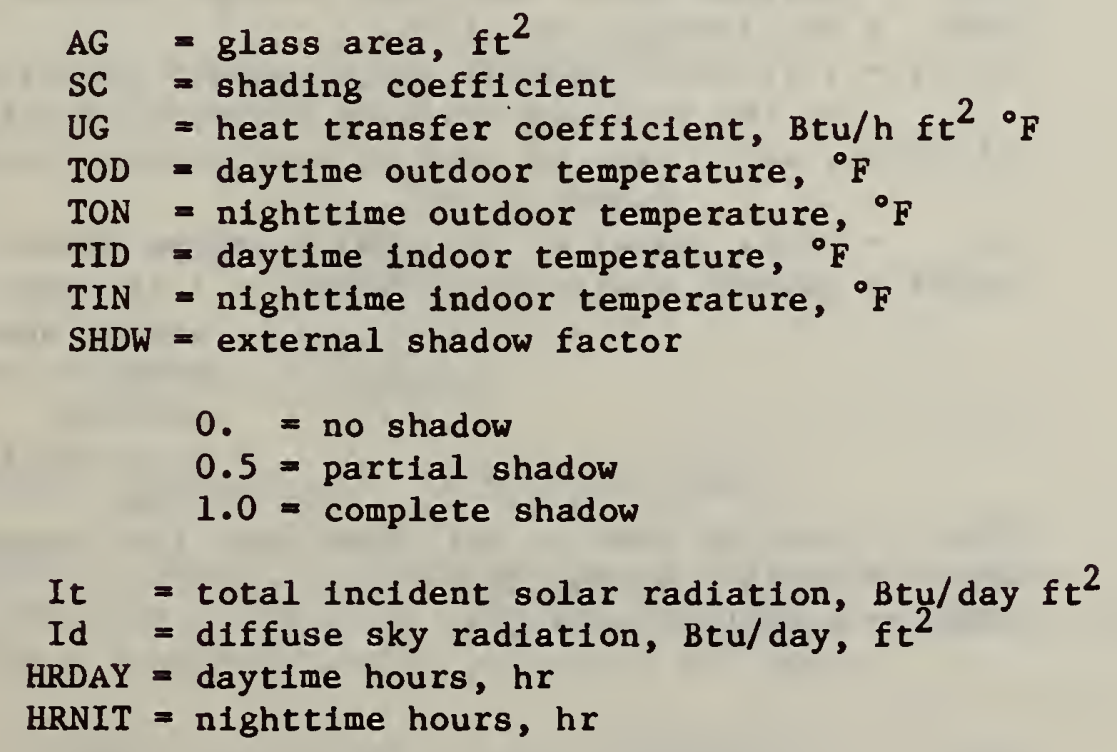


Output: Daytime and nighttime window heat gain

$$
\begin{aligned}
I= & (I t-I d) *(1-S H D W)+I d \\
& \text { Daytime } \quad Q G D=A G *[I *(S C) * 0.87+U G *(T O D-T I D) * \text { HRDY }] \\
& \text { Nighttime } \quad Q G N=A G *[U G *(T O N-T I N) * \text { HKNIT }]
\end{aligned}
$$

\subsection{HLHG}

Heat loss and heat gain calculations

Input:

$$
\begin{aligned}
& \text { QID = daytime infiltration heat gain, Btu/day } \\
& \text { QIN = nighttime infiltration heat gain, Btu/day } \\
& \text { QWD = daytime wall heat gain, Btu/day } \\
& \text { QWN = nighttime wall heat gain, Btu/day } \\
& \text { QDD = daytime door heat gain, Btu/day } \\
& \text { QDN = nighttime door heat gain, Btu/day } \\
& \text { QCD = daytime ceiling heat gain, Btu/day } \\
& \text { QCN = nighttime ceiling heat gain, Btu/day } \\
& \text { QGD = daytime window heat gain, Btu/day } \\
& \text { QGN = nighttime window heat gain, Btu/day } \\
& \text { QFD = daytime floor heat gain, Btu/day } \\
& \text { QFN = nighttime floor heat gain, Btu/day } \\
& \text { QRD = daytime internal heat gain, Btu/day } \\
& \text { QRN = nighttime internal heat gain, Btu/day }
\end{aligned}
$$

The above values will be negative if they are heat loss.

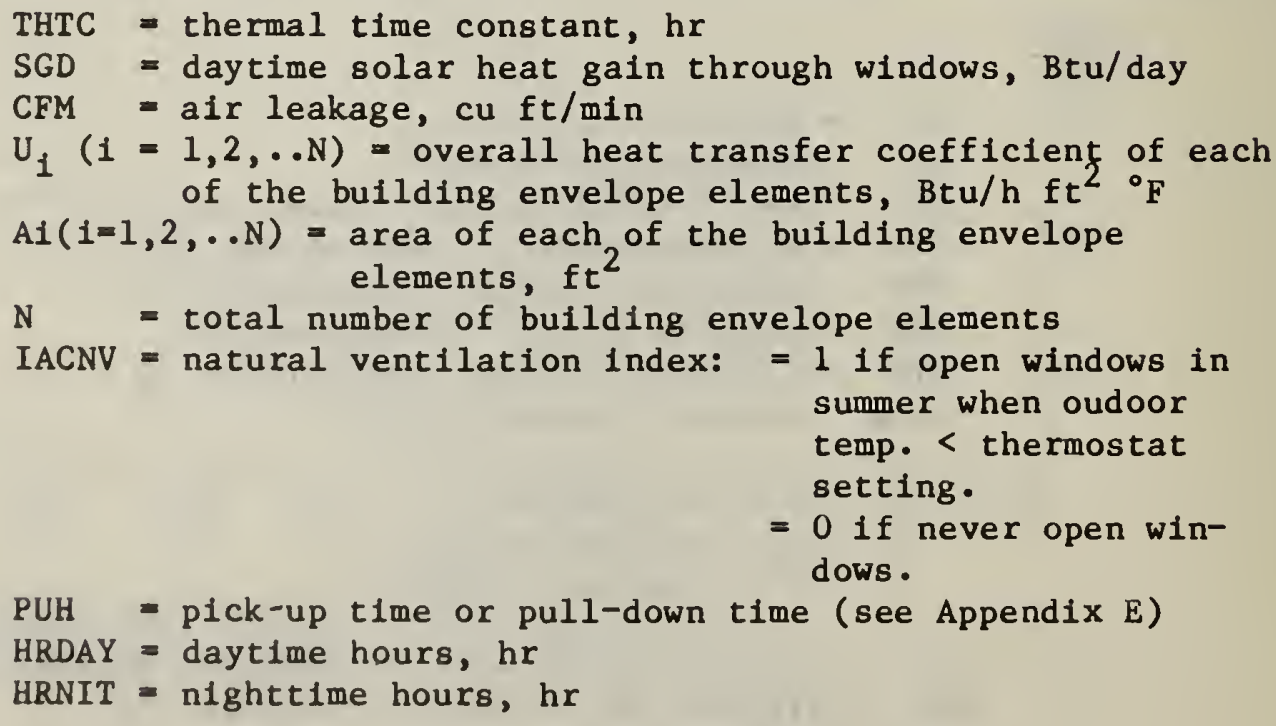


Output:

$$
\begin{aligned}
& \text { HLD = daytime sensible heating load, Btu/day } \\
& \text { HLN = nighttime sensible heating load, Btu/day } \\
& \text { CLD = daytime sensible cooling load, Btu/day } \\
& \text { CLN = nighttime sensible cooling load, Btu/day }
\end{aligned}
$$

\section{Calculation Procedure}

This routine uses the building thermal time constant (THTC) concept, detall of which is given in the Appendix E.

Total envelope heat gain

daytime

$$
\mathrm{QTD}=\mathrm{QID}+\mathrm{QWD}+\mathrm{QDD}+\mathrm{QGD}+\mathrm{QFD}+\mathrm{QRD}+\mathrm{QCD}
$$

nighttime

$$
\mathrm{QTN}=\mathrm{QIN}+\mathrm{QWN}+\mathrm{QDN}+\mathrm{QGN}+\mathrm{QFN}+\mathrm{QRN}+\mathrm{QCN}
$$

If $T I D=T I N$

$$
\begin{aligned}
& \text { HLD }=\text { QTD if } 0 T D<0 \\
& \text { HLN }=\text { QTN if QTN } \angle 0 \\
& C L D=\text { QTD if QTD }>0 \\
& C L N=\text { QTN if QTN }>0
\end{aligned}
$$

otherwise the following calculations are necessary

Envelope heat transfer factor

$$
\mathrm{ZK}=\sum_{i=1}^{N} \mathrm{U}_{1} \mathrm{~A}_{1}+1.08 * \mathrm{CFM}
$$

also let

$$
\begin{aligned}
& Z X=\operatorname{EXP}\left(\frac{-P U H}{T H T C}\right) \\
& Z Y=\operatorname{EXP}\left(\frac{-12+P U H}{T H T C}\right)
\end{aligned}
$$

Cooling season calculations: (QTD>0 and QTN $>0$ )

PULDWN: Evening pull-down cooling requirement necessary to lower the building temperature from TID of daytime to TIN of nighttime within a specified pickup period of PUH hours.

$$
\text { PULDWN }=Z K *\left(T O N-T I D+\frac{(T I D-T I N)}{1-Z X}\right) \quad * \text { PUH }
$$


$\mathrm{DH}=$ duration of morning warm-up hour during which the cooling is off

$$
\begin{aligned}
& \mathrm{DH}=\mathrm{THTC} * \ln \left(\frac{\mathrm{ZQ}-\mathrm{TIN}+\mathrm{TOD}+\mathrm{TD}}{\mathrm{ZQ}-\mathrm{TID}+\mathrm{TOD}}\right) \\
& \text { where } \mathrm{ZQ}=\frac{\mathrm{SGD}+\mathrm{QRD}}{\mathrm{HRDAY} \mathrm{Z}^{\star} \mathrm{KK}}
\end{aligned}
$$

CON: total daytime cooling hour

$$
\mathrm{CON}=\mathrm{HRDAY}-\mathrm{DH}
$$

daytime cooling load

$$
\mathrm{QTD}=\mathrm{QTD} * \mathrm{CON} / 12
$$

QTN: actual nighttime cooling requirement

$$
\mathrm{CLN}=\frac{\mathrm{QTN} *(\text { HRNIT }-\mathrm{PUH})}{\mathrm{HRNIT}}+\mathrm{PULDWN} * \mathrm{PUH}
$$

If the natural cooling is used as

$$
\text { if } \begin{aligned}
& \mathrm{IACNV}=1, \mathrm{CLD}=0 \text { for } \mathrm{TOD} \leq \mathrm{TID} \\
& \mathrm{CLN}=0 \text { for } \mathrm{TON} \leq \mathrm{TIN}
\end{aligned}
$$

Heating season calculations: $(Q T D<0$ and $Q T N<0)$

PICKUP: early morning pick-up heating requirement necessary to raise the building temperatures from TIN to TID within PUH hours

$$
\text { PICKUP }=2 \mathrm{~K} * \quad\left((\mathrm{TIN}-\mathrm{TOD})+\frac{(\mathrm{TID}-\mathrm{TIN})}{1-\mathrm{ZX}}\right) * \mathrm{PUH}
$$

$\mathrm{DH}$ : duration of evening cool-down hours during which the heating system is off

$$
\begin{aligned}
& \mathrm{DH}=\mathrm{THTC}^{*} \ln \quad\left(\frac{\mathrm{TID}+\mathrm{TD}-\mathrm{TON}-\mathrm{ZQ}}{\mathrm{TIN}-\mathrm{TON}-\mathrm{ZQ}}\right) \\
& \text { when } \mathrm{ZQ}=\frac{\mathrm{QRN}}{\mathrm{ZK^{ \star } \mathrm { HRNIT }}}
\end{aligned}
$$

CON: total heating hours

$$
\text { CON }=\text { HRNIT-DH }
$$

daytime heating load

$$
\text { HCD }=\frac{\text { QTD* }(\text { HRNIT }- \text { PUH })}{\text { HRNIT }}-\text { PICKUP * PUH }
$$


nighttime heating requirement

$$
\mathrm{HLN}=\mathrm{QTN} * \mathrm{CON} / \mathrm{HRNIT}
$$

5.9. HCRT: Heating and cooling requirement calculations

Input:

$$
\begin{aligned}
& \text { HLD = daytime sensible heating load, Btu/day } \\
& \text { HCN = nighttime sensible heating load, Btu/day } \\
& \text { CLD = daytime sensible cooling load, Btu/day } \\
& \text { CLN = nighttime sensible cooling load, Btu/day } \\
& \mathrm{HL} \quad=\text { daily sensible heat load = HLD + HLN } \\
& \text { HG = daily sensible cooling load = CLD + CLN } \\
& \text { RLGH = latent heat gain } \\
& \text { AIRLOS }=\text { air leakage through ducts = AIR LOSS } \times 100 \% \\
& \text { supply air }
\end{aligned}
$$

Heating requirement: $\mathrm{HREQ}=\mathrm{HL} *(1.0+\mathrm{AIRLOS} / 100)$

$$
\text { if cooling season, } H R E Q=0
$$

Cooling requirements: $\quad C R E Q=(H G+L H G) *(1.0+$ AIRLOS $/ 100)$

if open windows in summer when outdoor

temp. < thermostat setting, LHG $=0$

if heating season, $C R E Q=0$

\subsection{EREQ: Energy requirement}

Input :

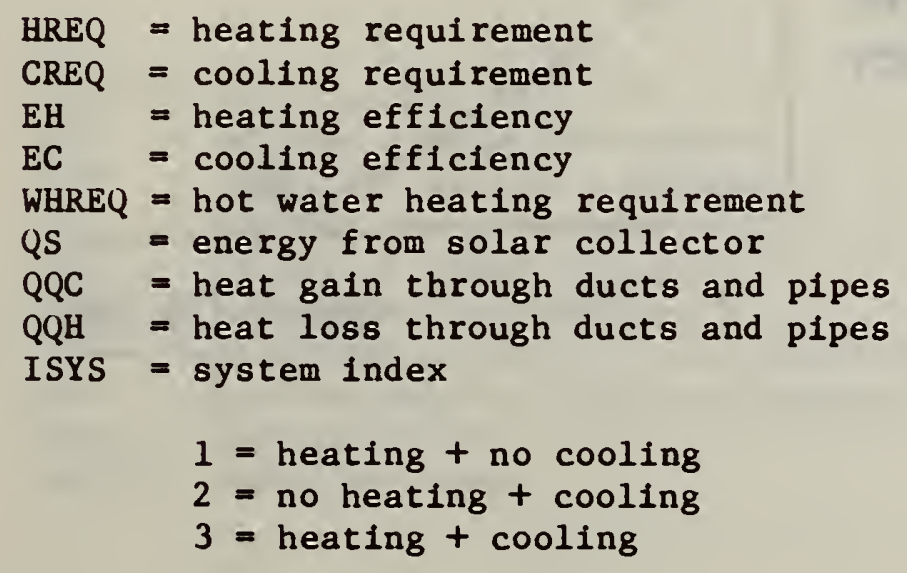


Output:

EREQ (Energy Requirement)

\begin{tabular}{ccc}
\hline System Index & $\begin{array}{c}\text { Heating Energy } \\
\text { Requirement }\end{array}$ & $\begin{array}{c}\text { Cooling Energy } \\
\text { Requi rement }\end{array}$ \\
\hline ISYS $=1$ & $(\mathrm{HREQ}+\mathrm{WHREQ}+\mathrm{QS}+\mathrm{QQH}) / \mathrm{EH}$ & 0 \\
2 & $($ WHREQ $+\mathrm{QS}+\mathrm{QQH}) / \mathrm{EH}$ & $(\mathrm{CREQ}+\mathrm{QQC})$ \\
& $(\mathrm{HREQ}+\mathrm{WHREQ}+\mathrm{QS}+\mathrm{QQH}) / \mathrm{EH}$ & $(\mathrm{CREQ}+\mathrm{QQC})$ \\
\hline
\end{tabular}

5.11. SEU: Solar collector heat gain

Input:

$\mathrm{SA}, \mathrm{SB}=$ Collector efficiency curve data

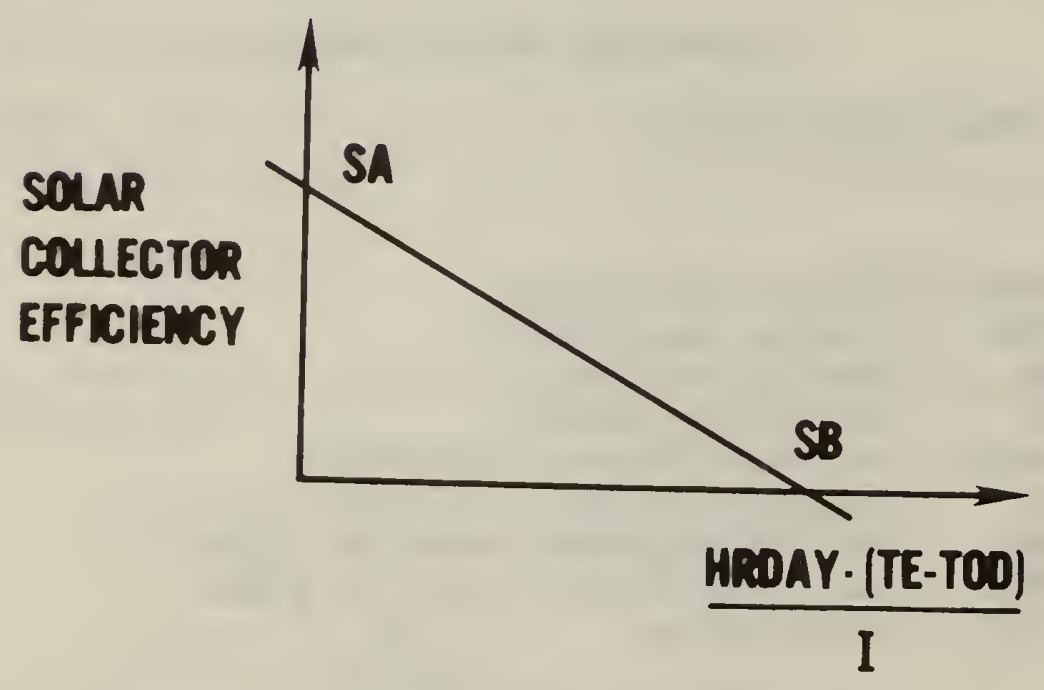

Typical solar collector performance. 
High Performance

0.8

1.2

(double glaze, selective surface)

Medium Performance

0.75

1.0

(double glaze, common black)

(single glaze, selective surface)

Low Performance

0.7

0.8

(single glaze, common black)

$\mathrm{TE}=$ inlet fluid temperature to the collector, ${ }^{\circ} \mathrm{F}$

TOD = daytime outdoor temperature, ${ }^{\circ} \mathrm{F}$

I $\quad$ daily total solar radiation, Btu/day

SUF = solar heat utilization factor

0.8 for large storage tank system

0.5 for small storage tank system

AS $=$ collector a rea, $\mathrm{ft}^{2}$

HRDAY = daytime hours, hr

Solar heat utilized

$$
\mathrm{QS}=\mathrm{AS} * \mathrm{SA} *\left(1-\frac{\mathrm{HRDAY} *(\mathrm{TE}-\mathrm{TOD})}{\mathrm{SB} * \mathrm{I}}\right) * \mathrm{SUF} * \mathrm{I}
$$

\subsection{QI: Infiltration heat gain}

\section{Input:}

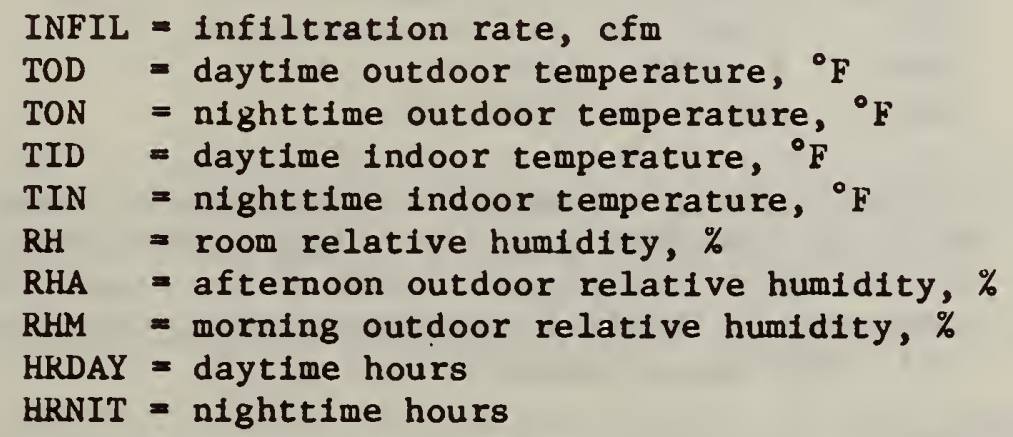

Output:

Daytime sensible heat gain

QID $=1.08 *$ INF IL* (TOD-TID)* HRDAY

Nighttime sensible heat gain

QIN $=1.08 *$ INF IL* $($ TON-TIN $) * H R N I T$ 
Latent heat

Determine the humidity ratio of indoor and outdoor air from psychrometric chart or by calling the psychrometric routine described in (5.15).

Calculate indoor humidity ratio WIN and WID by nighttime Call DBRH (TIN, RH, WIN) and daytime Call DBRH (TID, RH, WID).

Determine the daytime and nighttime humidity ratios of outdoor a1r, WOD and WON by

Cal1 DBRH (TOD, RHA, WOD)

Call DBRH (TON, RHM, WON)

Daytime latent heat gain:

QILD $=4.5 *$ INFIL* $($ WOD-WID $) * 1061 * \mathrm{HRDAY}$

Nighttime latent heat gain:

QILN $=4.5 * I N F I L *($ WON-WIN $) * 1061 *$ HRNIT

It is important to note that QID, QIN, QILD and QILN are

all zero when the natural cooling is used to minimize

or eliminate the need for mechanical cooling.

5.13. QECHG: Opaque envelope conduction heat gain (walls, doors, roofs and floors)

Input: For all the opaque envelope such as atticless roofs, walls and doors, the following input data should be provided:

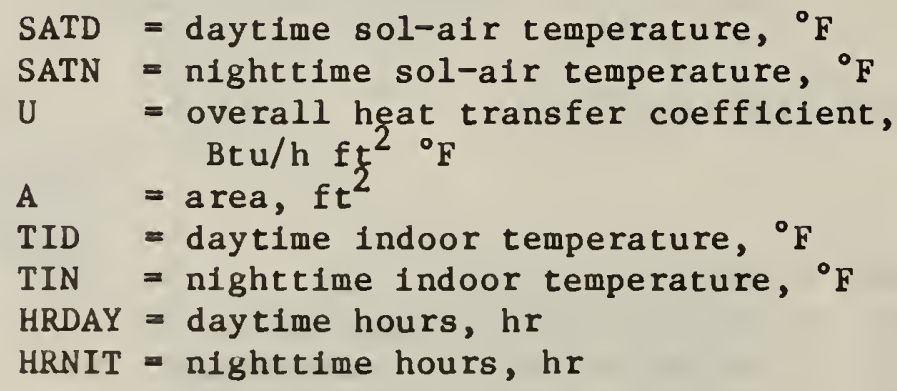

For daytime heat gain, $Q D=U^{*} A^{*}($ SATD-TID)*HRDAY Btu/day For nighttime heat gain, $Q N=U^{*} A^{*}($ SATN-TIN)*HRNIT Btu/day For the attic ceiling and crawl space floor, the sol-air temperature should be replaced by the attic temperature and craw1-space temperature.

\subsection{QR: Internal heat gain}

Input:

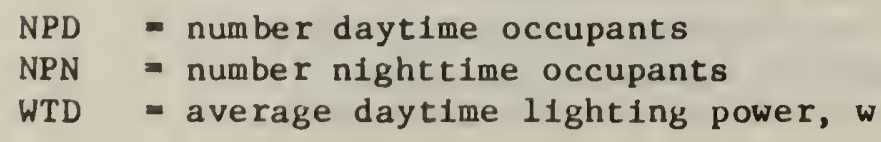




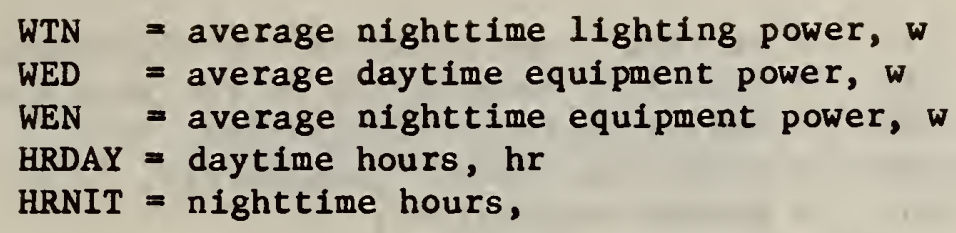

Sensible heat gain

It is assumed that $1 / 3$ of the equipment heat is used for the evaporation of water vapor such as from cooking.

$$
\begin{aligned}
& \text { Daytime: QRSD }=[\text { NPD*240+[WTD+(WED*0.66) }] * 3.413] * \mathrm{HRDAY} \\
& \text { Nighttime: } Q R S N=[\text { NPN*240+[WTN+(WEN*0.66) }] * 3.413] * \text { HRNIT }
\end{aligned}
$$

Latent heat gain

$$
\begin{aligned}
& \text { Daytime: } Q R L D=[N P D * 160+(\text { WED*0.34)*3.413]*HRDAY } \\
& \text { Nighttime: QRLN }=[\text { NPN*160+(WEN*0.34)*3.413]*HRNIT }
\end{aligned}
$$

5.15. DBRH: Relative humidity routine (see Appendix C-27)

Input :

$$
\begin{aligned}
& \mathrm{DB} \quad=\text { dry-bulb temperature, }{ }^{\circ} \mathrm{F} \\
& \mathrm{RH} \quad=\text { relative humidity, } \%
\end{aligned}
$$

Calculation algorithms for psychrometric routines are provided in reference [4].

Output:

$$
W \quad=\text { humidity ratio, } 1 \mathrm{~b} / 1 \mathrm{~b}
$$

5.16. BSMT: Basement temperature and heat loss calculation

Input :

$$
\begin{aligned}
& \mathrm{ZK}=\text { ground thermal conductivity Btu-in/hr } \mathrm{ft}^{2}{ }^{\circ} \mathrm{F} \\
& \mathrm{UBW}=\text { basement wall heat conductance, Btu/hr } \mathrm{ft}^{2}{ }^{\circ} \mathrm{F} \text { / } \\
& \mathrm{UBF}=\text { basement floor heat conductance, Btu/hr } \mathrm{ft}^{2}{ }^{\circ} \mathrm{F} \text { - } / \\
& \text { UFLRI = heat conduftance of floor above the basement, } \\
& \mathrm{Btu} / \mathrm{hr} \mathrm{ft}^{20} \mathrm{~F} \\
& \text { BWAEX = Area of the exposed section of the basement wall, } \mathrm{ft}^{2} \\
& \text { BWA = basement wall area, } \mathrm{ft}^{2} \\
& \text { BFA = basement floor a rea, } \mathrm{ft}^{2} \\
& \mathrm{~L} \quad=\text { height of the basement wall which is ground covered, } \mathrm{ft}
\end{aligned}
$$

* UBW and UBF are to be determined from the room air to the external surface of the wall/slab (soil interface). 


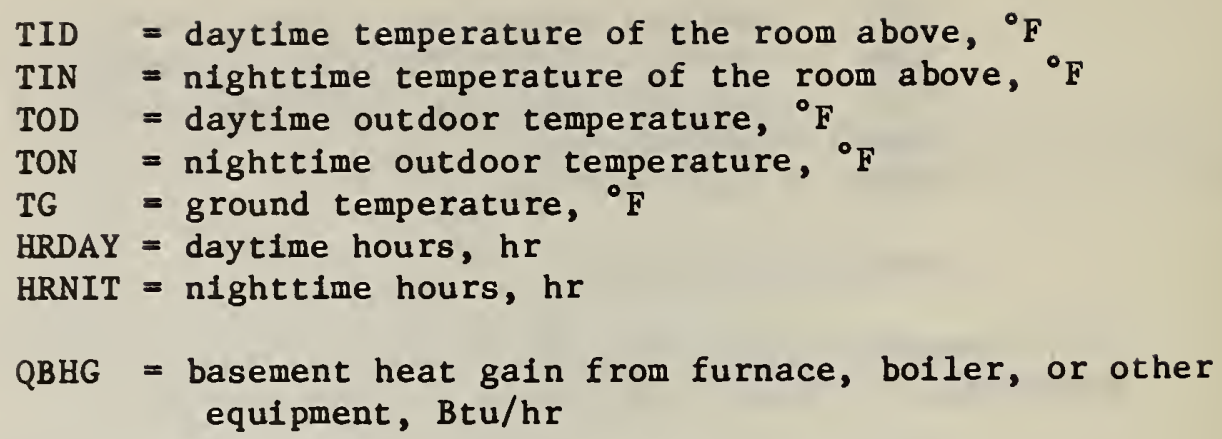

Output:

$$
\begin{aligned}
& \mathrm{BSMTD}=\text { daytime basement temperature, }{ }^{\circ} \mathrm{F} \\
& \text { BSMTN }=\text { nighttime basement temperature, }{ }^{\circ} \mathrm{F} \\
& \mathrm{BQFD}=\text { daytime basement heat loss, Btu/day } \\
& \mathrm{BQFN}=\text { nighttime basement heat loss, Btu/day } \\
& \mathrm{TO}=(\text { TOD }+ \text { TON } / 2.0
\end{aligned}
$$

There are no exact solutions, similar to those described in the slab-ongrade calculation, for the basement wall heat condition. An approximate value of UW may be obtained by the following equation.

$$
\begin{aligned}
& U W=\frac{1}{\frac{1}{U F W}+\frac{1}{\mathrm{HO}} \quad \text { for the exposed section. }} \\
& U W=\frac{2 * \mathrm{ZK}}{\left(\pi{ }^{\star} \mathrm{L}\right)} * \ln \left(1+\frac{\pi * \mathrm{UFW} * \mathrm{~L}}{2 * \mathrm{ZK}}\right) \begin{array}{l}
\text { for the ground-covered } \\
\text { section. }
\end{array}
\end{aligned}
$$

The latter equation was derived from the assumption that the heat flow path between the basement wall and the ground surface is a quarter circle. Basement flow heat transfer coefficient.

$$
\begin{aligned}
& \text { UF = The value should be determined by the same procedure }
\end{aligned}
$$

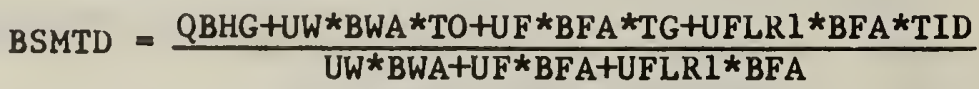

$$
\begin{aligned}
& \text { BSMTN }=\frac{Q B H G+U W{ }^{*} B W A{ }^{*} T O+U F * B F A * T G+U F L R 1 * B F A * T I N}{U W{ }^{*} B W A+U F * B F A+U F L R 1{ }^{*} B F A}
\end{aligned}
$$


If basement is heated

$$
\begin{aligned}
& \mathrm{BQFD}=(-\mathrm{UW} *(\mathrm{TID}-\mathrm{TO}) * \mathrm{BWA}-\mathrm{UF} *(\mathrm{TID}-\mathrm{TG}) * \mathrm{BFA}) * \mathrm{HRDAY} \\
& \mathrm{BQFN}=(-\mathrm{UW} *(\mathrm{TIN}-\mathrm{TO}) * \mathrm{BWA}-\mathrm{UF} *(\mathrm{TIN}-\mathrm{TG}) * \mathrm{BFA}) * \mathrm{HRNIT} \\
& \mathrm{BSMTD}=\mathrm{TID}, \mathrm{BSMTN}=\mathrm{TIN}
\end{aligned}
$$

If basement is not heated $B Q F D \& B Q F N$ are calculated by using Subroutine

QECHG (=7.13. Opaque envelope conduction heat

gain calculations) and the basement temperatures,

BSMTD and BSMTN above.

\subsection{HWHREQ: hot water heating requirement}

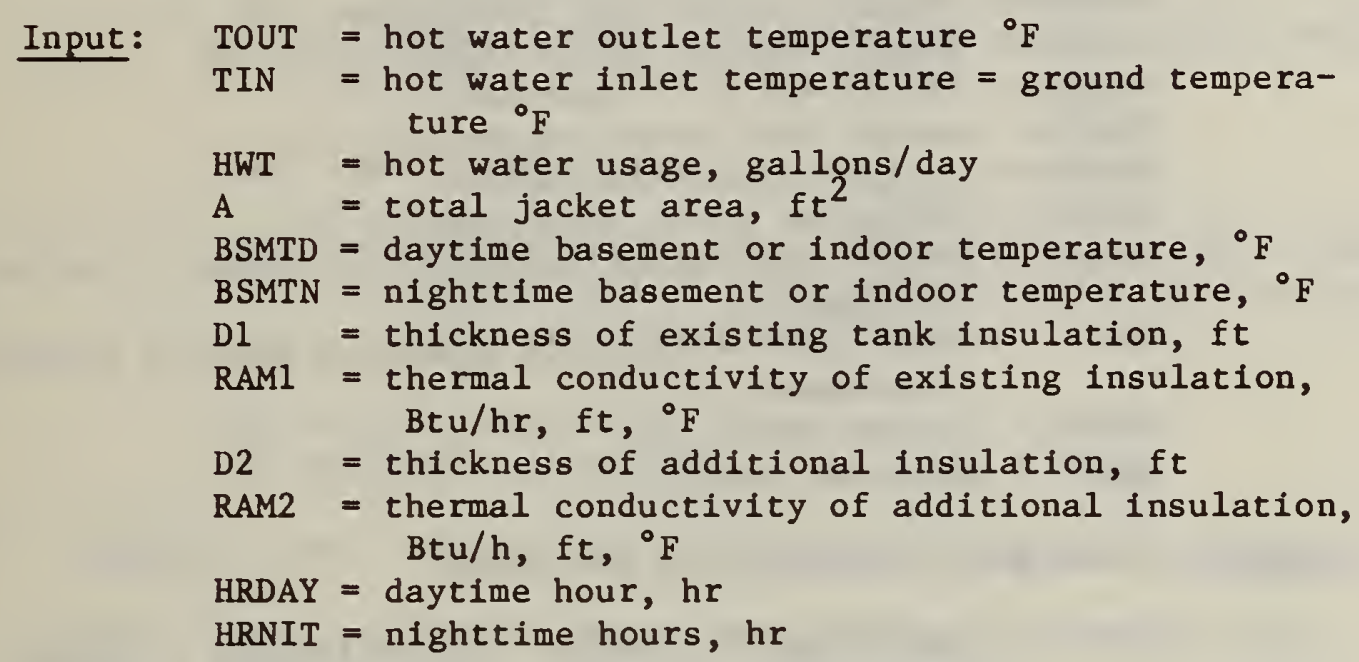

Output: Heat loss through existing jacket insulation a round the hot water tank

$$
\text { HLHWH } \left.1=\mathrm{U} 1{ }^{*} \mathrm{~A} *((\text { BSMTD }-\mathrm{TOUT}) * \mathrm{HRDAY})+(\text { BSMTN}-\mathrm{TOUT}) * \mathrm{HRNIT}\right)
$$

where

$\mathrm{U} 1=1.0 /(0.685+\mathrm{D} 1 / \mathrm{RAM1})$

Heat loss through additional jacket insulation of hot water tank

$$
\text { HLHWH2 } \left.=\mathrm{U} 2{ }^{*} \mathrm{~A} *((\text { BSMTD-TOUT }) * \text { HRDAY })+(\text { BSMTN-TOUT }) * \text { HRNIT }\right)
$$

where

$$
\mathrm{U} 2=1.0 /(0.685+\mathrm{D} 1 / \mathrm{RAM} 1+\mathrm{D} 2 / \mathrm{RAM} 2)
$$

Energy saving by additional insulation over the hot water tank

$$
\text { SAVE }=\text { HLHWH2-HLHWH1 }
$$

Hot water heating requirement, including jacket heat loss 
WHREQ $=500.0 / 60.0 *($ TIN-TOUT $) * H W T+$ HLHWH2

If WHREQ $>0$, WHREQ $=0$

Hot water heating requirement, excluding jacket heat loss WHREQ2 = WHREQ - HLHWH2

5.18. CSDUPI: heat loss and gain through ducts and pipes in crawl space

Input: $\mathrm{ADUCT}=$ total surface area of duct in crawl space, $\mathrm{ft}^{2}$ UDUCT $=\mathrm{U}$ value of duct, Btu/h $\mathrm{ft}^{2}{ }^{\circ} \mathrm{F}$

$\mathrm{APIPE}=$ total surface area of pipe in crawl space, $\mathrm{ft}^{2}$

UPIPE = U value of pipe, Btu/h $\mathrm{ft}^{2}{ }^{\circ} \mathrm{F}$

TCSUPA = supply chilled air temperature, ${ }^{\circ} \mathrm{F}$

TCSUPW = supply chilled water temperature, ${ }^{\circ} \mathrm{F}$

THSUPA = supply hot air temperature, ${ }^{\circ} \mathrm{F}$

THSUPW = supply hot water temperature, ${ }^{\circ} \mathrm{F}$

CRAWLD = daytime crawl temperature, ${ }^{\circ} \mathrm{F}$

CRAWLN $=$ nighttime crawl temperature, ${ }^{\circ} \mathrm{F}$

CFAC = factor for estimating operation time of cooling equipment

HFAC = factor for estimating operation time of heating equipment

HRDAY = daytime hours, hr

HRNIT = nighttime hours, hr

Output: Heat gain through ducts and pipes

QC = ADUCT*UDUCT* ( (CRAWLD - TCSUPA $) * H R D A Y+($ CRAWLN TCSUPA $) *$ HRNIT $) *$ CFAC + APIPE*UPIPE* ( CRAWLD TCSUPW $) *$ HRDAY $+($ CRAWLN - TCSUPW $) * H K N I T) * C F A C$

Heat loss through ducts and pipes

QH = ADUCT*UDUCT* ( (CRAWLD - THSUPA $) *$ HKDAY + (CKAWLN - THSUPA $)$ *HRNIT) *HFAC + APIPE*UPIPE* ( (CRAWLD - THSUPW $)$ *HRWAY + (CRAWLN - THSUPW) *HRNIT)*HFAC

If cooling season, $\mathrm{QH}=0$

If heating season, $Q C=0$

5.19. ASDUPI: heat loss and gain through ducts and pipes in attic space

Input: $\quad A D U C T=$ total surface area of duct in attic space, $\mathrm{ft}^{2}$ UDUCT $=U$ value of duct, Btu/h, $\mathrm{ft}^{2},{ }^{\circ} \mathrm{F}$

APIPE = total surface area of pipe in attic space, $\mathrm{ft}^{2}$ UPIPE = U value of pipe, Btu/h, $\mathrm{ft}^{2},{ }^{\circ} \mathrm{F}$

TCSUPA = supply chilled air temperature, ${ }^{\circ} \mathrm{F}$

TCSUPW = supply chilled water temperature, ${ }^{\circ} \mathrm{F}$

THSUPA $=$ supply hot air temperature, ${ }^{\circ} \mathrm{F}$ 


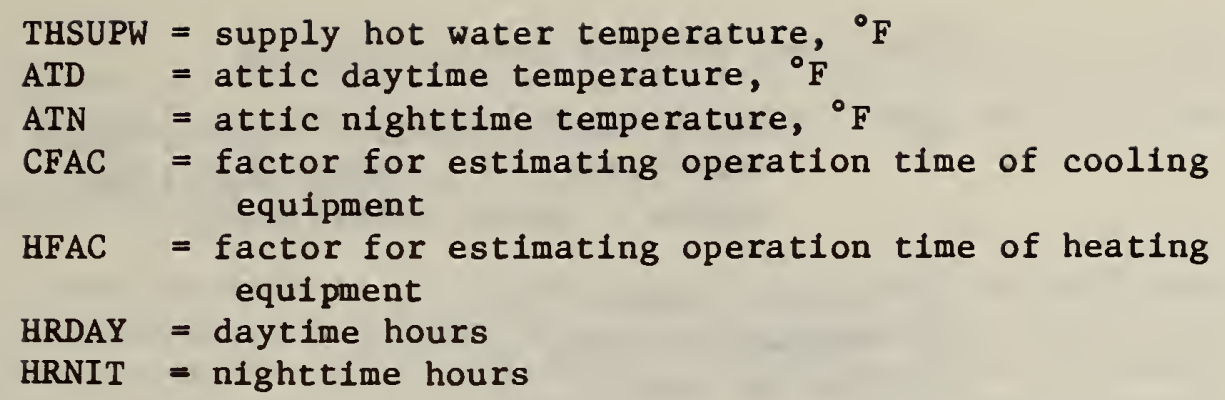

\section{Output:}

Heat gain through ducts and pipes

$$
\begin{aligned}
& \text { QC }=\text { ADUCT*UDUCT* ((ATD - TCSUPA } * \text { HRDAY + (ATN - TCSUPA) } \\
& \text { *HRNIT }) * C F A C+\text { APIPE*UPIPE* }((A T D-T C S U P W) * H R D A Y+ \\
& \text { (ATN - TCSUPW)*HRNIT)*CFAC }
\end{aligned}
$$

Heat loss through ducts and pipes

$$
\begin{aligned}
\mathrm{QH}= & \text { ADUCT*UDUCT* }((\text { ATD }- \text { THSUPA }) * H R D A Y+(\text { ATN }- \text { THSUPA }) \\
& \text { *HRNIT)*HFAC + APIPE*UPIPE* }((\text { ATD }- \text { THSUPW }) * H R D A Y ~+ \\
& (\text { ATN }- \text { THSUPW }) * H R N I T) * H F A C
\end{aligned}
$$

If cooling season, $\mathrm{QH}=0$

If heating season, $\mathrm{QC}=0$

5.20. BMDUPI: heat loss and gain through ducts and pipes in basement

Input: $A D U C T=$ total surface area of duct in basement, $\mathrm{ft}^{2}$

$$
\begin{aligned}
& \text { UDUCT }=\mathrm{U} \text { value of duct, Btu/h } \mathrm{ft}^{2}{ }^{\circ} \mathrm{F} \\
& \text { APIPE = total surface area of pipe in basement, } \mathrm{ft}^{2} \\
& \text { UPIPE = U value of } \mathrm{pipe}, \mathrm{Btu} / \mathrm{h} \mathrm{ft}^{2}{ }^{\circ} \mathrm{F} \\
& \text { TCSUPA = supply chilled air temperature, }{ }^{\circ} \mathrm{F} \\
& \text { TCSUPW = supply chilled water temperature, }{ }^{\circ} \mathrm{F} \\
& \text { THSUPA = supply hot air temperature, }{ }^{\circ} \mathrm{F} \\
& \text { THSUPW }=\text { supply hot water temperature, }{ }^{\circ} \mathrm{F} \\
& \text { BSMTD = basement daytime temperature, }{ }^{\circ} \mathrm{F} \\
& \text { BSMTN = basement nighttime temperature, }{ }^{\circ} \mathrm{F} \\
& \text { CFAC = factor for estimating operation time of } \\
& \text { cooling equipment } \\
& \text { HFAC = factor for estimating operation time of } \\
& \text { heating equipment } \\
& \text { HRDAY = daytime hours, } h r \\
& \text { HRNIT = nighttime hours, hr }
\end{aligned}
$$

Output:

Heat gain through ducts and pipes

$$
\begin{aligned}
& \text { QC } \quad=\text { ADUCT*UDUCT* }((B S M T D-T C S U P A) * H R D A Y+(B S M T N-T C S U P A) \\
& \text { *HRNIT }) * \text { CFAC + APIPE*UPIPE* ( (BSMTD - TCSUPW }) * H K D A Y+ \\
& (\text { BSMTN }- \text { TCSUPW }) * \text { HRNIT }) * C F A C
\end{aligned}
$$


Heat loss through ducts and pipes
QH $=$ ADUCT*UDUCT* ( *HRNIT)*HFAC + APIPE*UPIPE* ( (BSMTD - THSUPW $){ }^{*} H R D A Y+$ $(B S M T N-$ THSUPW $) * H R N I T) * H F A C$

If cooling season, $\mathrm{QH}=0$

If basement heated, $\mathrm{QH}=0$

If heating season, $\mathrm{QC}=0$

5.21. OSDUPI: heat loss and gain through outdoor ducts and pipes

Input: $A D U C T=$ total surface area of outdoor duct, $\mathrm{ft}^{2}$

UDUCT = U value of duct, Btu/h $\mathrm{ft}^{2}{ }^{\circ} \mathrm{F}$

APIPE = total surface area of outdoor pipe, $\mathrm{ft}^{2}$

UPIPE = U value of pipe, Btu/h $\mathrm{ft}^{2}{ }^{\circ} \mathrm{F}$

TCSUPA = supply chilled air temperature, ${ }^{\circ} \mathrm{F}$

TCSUPW = supply chilled water temperature, ${ }^{\circ} \mathrm{F}$

THSUPA = supply hot air temperature, ${ }^{\circ} \mathrm{F}$

THSUPW = supply hot water temperature, ${ }^{\circ} \mathrm{F}$

TOD = daytime outdoor temperature, ${ }^{\circ} \mathrm{F}$

TON = nighttime outdoor temperature, ${ }^{\circ} \mathrm{F}$

CFAC = factor for estimating operation time of cooling equipment

HFAC = factor for estimating operation time of heating equipment

HRDAY = daytime hours, hr

HRNIT = nighttime hours, hr

Output:

Heat gain through ducts and pipes

QC = ADUCT*UDUCT* ( $T O D-T C S U P A) * H R D A Y+(T O N-T C S U P A)$ *HRNIT $){ }^{*}$ CFAC + APIPE*UPIPE* ((TOD - TCSUPW $) * H R D A Y+$ $($ TON - TCSUPW $) \star H R N I T) * C F A C$

Heat 1088 through ducts and pipes

QH $=$ ADUCT*UDUCT* ( $($ TOD - THSUPA $) * H R D A Y+(T O N-T H S U P A)$ *HRNIT $)$ *HPAC + APIPE*UPIPE* ((TOD - THSUPW $) * H R D A Y+$ $($ TON - THSUPW $) \star$ HRNIT $) \star H F A C$

If cooling season, $\mathrm{QH}=0$

If heating season, $\mathrm{QC}=0$

(is)

The routines described above are incbrporated into a Fortran program,

listing of which is given in Appendix C. 
Appendix D presents a description of the data file and suggested default values to be used for the heating and cooling requirement calculations.

\section{COMPARISON WITH DOE-2 RUNS}

Figures 5 and 6 are comparisons of annual heating and cooling requirements obtained by the simplified procedure described herein with those obtained by DOE-2, a comprehensive hourly simulation program for building energy analysis, for ten cities and for a combination of several energy conservation options as shown in Table 1 . The basic building data used for these comparative calculations are described in a recent report of the Lawrence Berkeley Laboratory ${ }^{2}$.

As can be seen, the total annual heating and cooling requirements obtained by the simplified procedure do not agree well with those determined by the DOE-2.

Since the DOE-2 uses TRY (Typical Reference Year) weather data, a set of monthly normal day data were generated from the TRY weather data tape and used in the simplified calculation procedure. The infiltration routine was also modified to be consistent with the DOE-2 algorithm. Figures 7 and 8 show the improved relationships between the two calculations as the result of these two adjustments. 


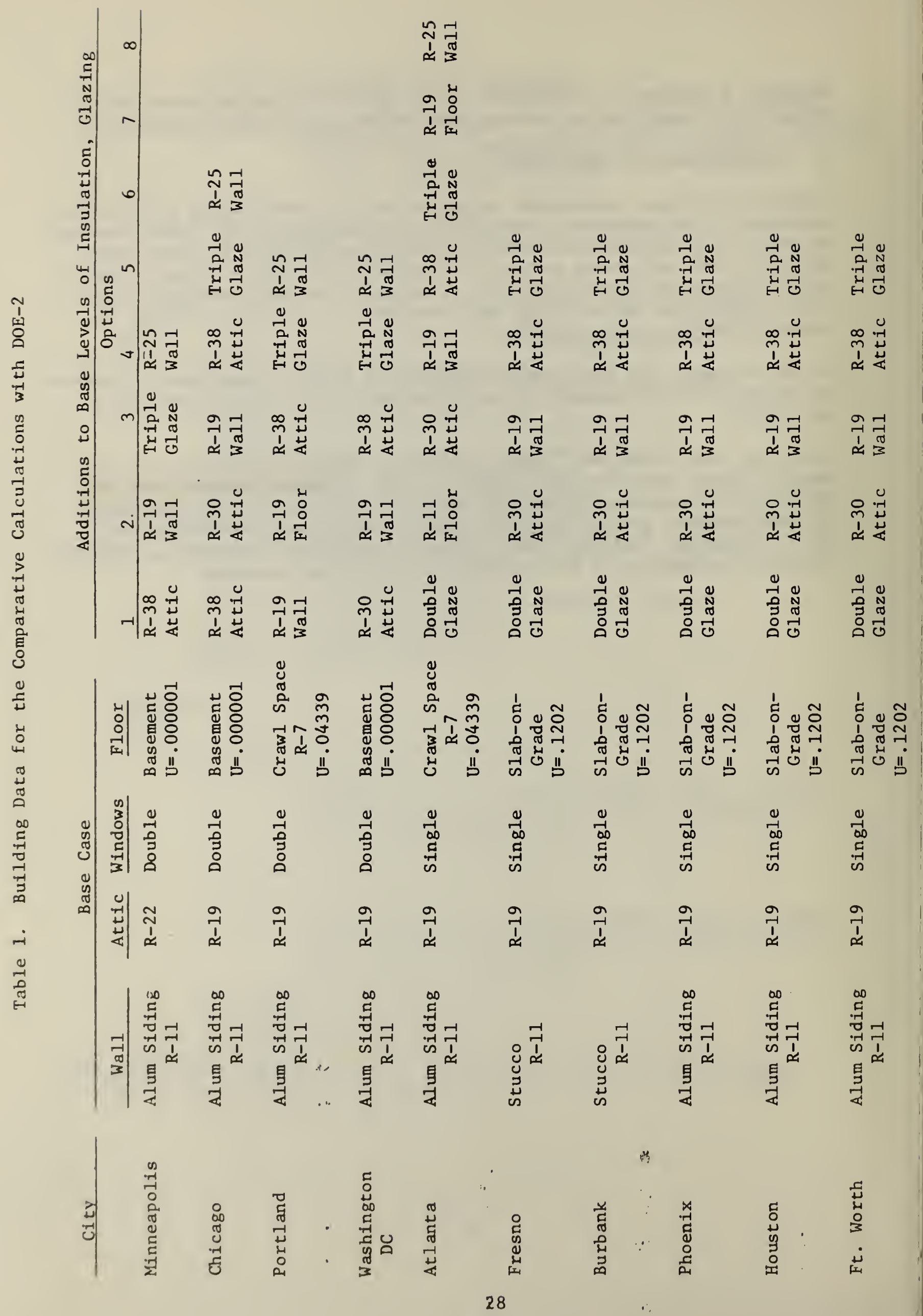




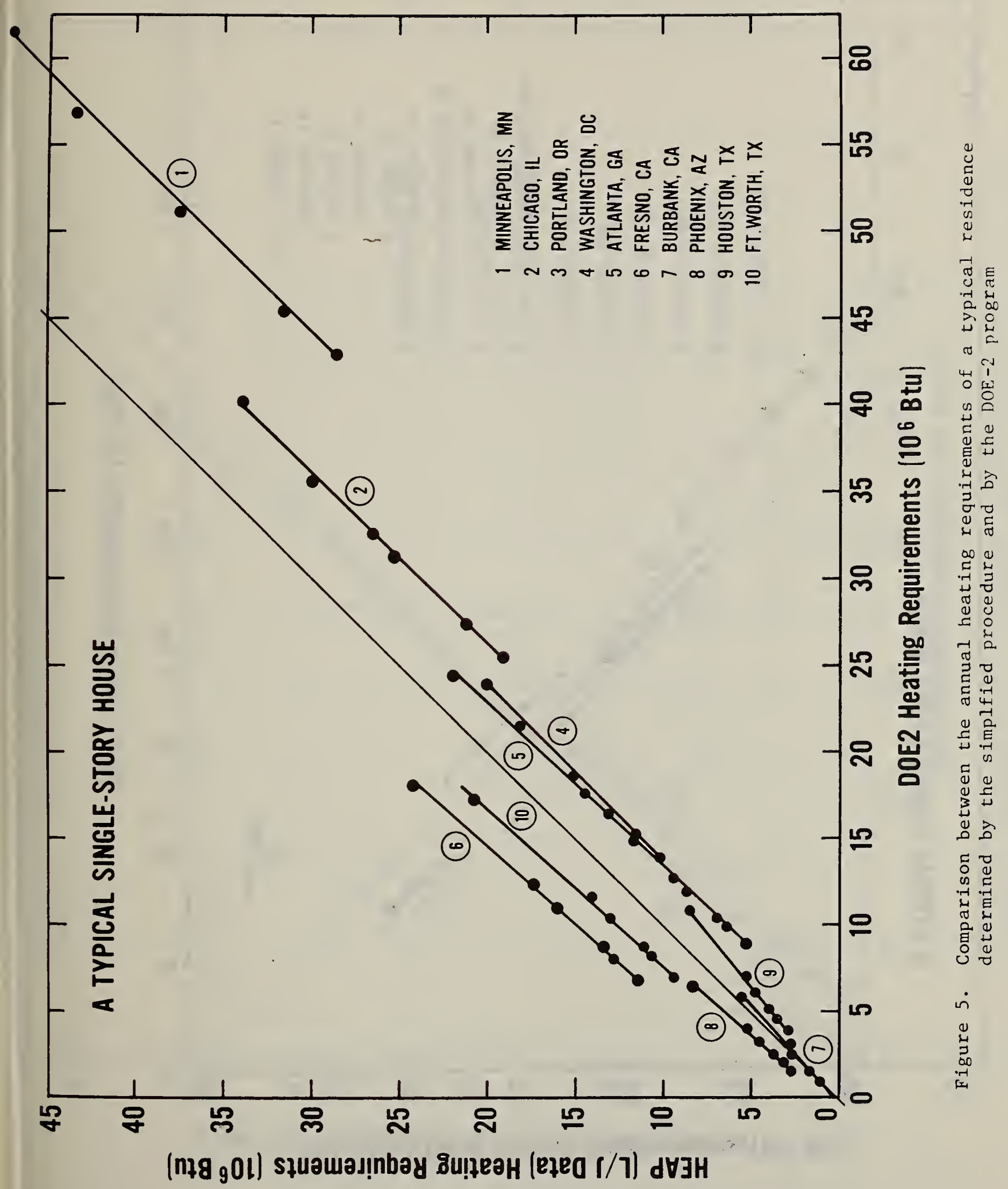




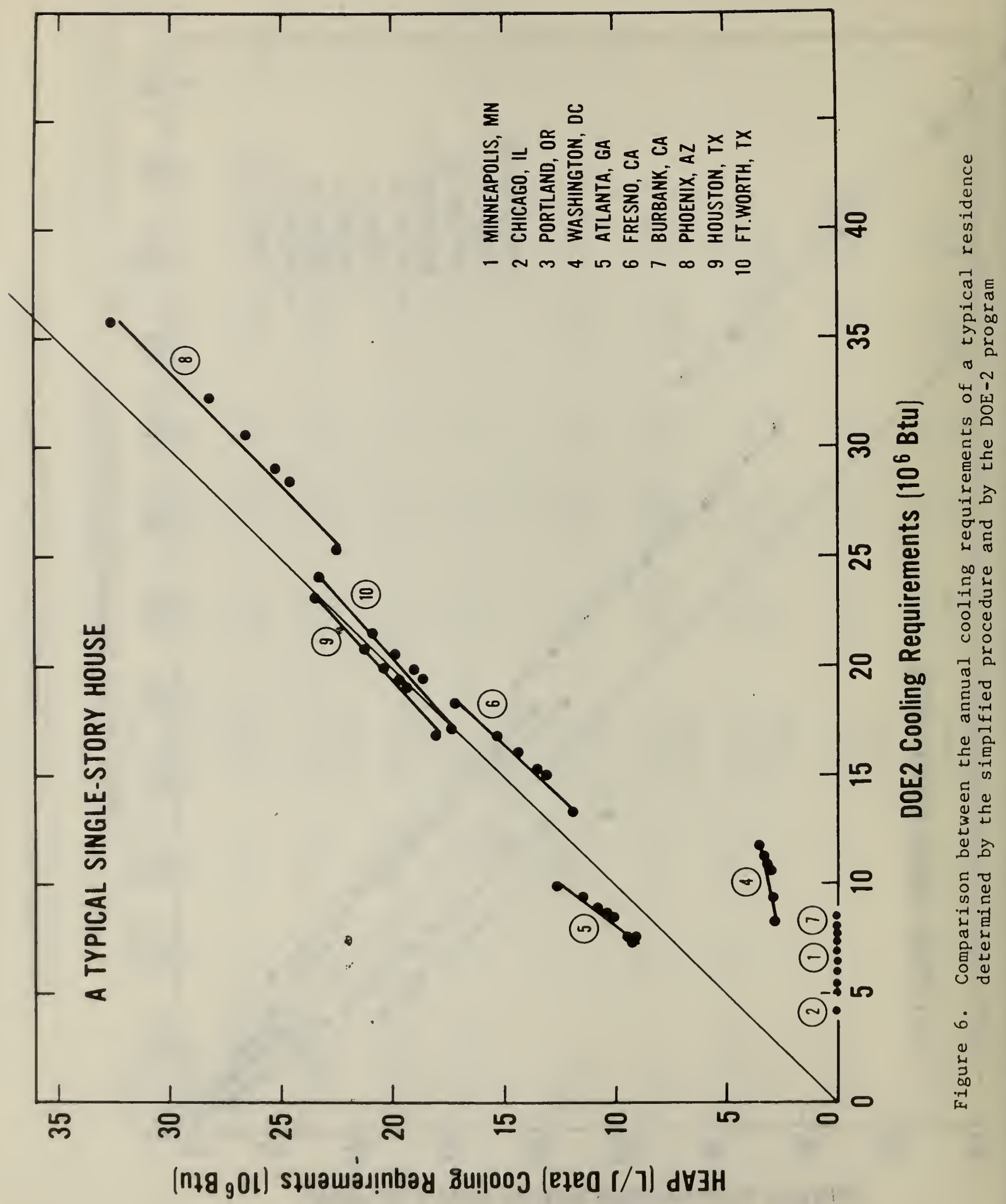




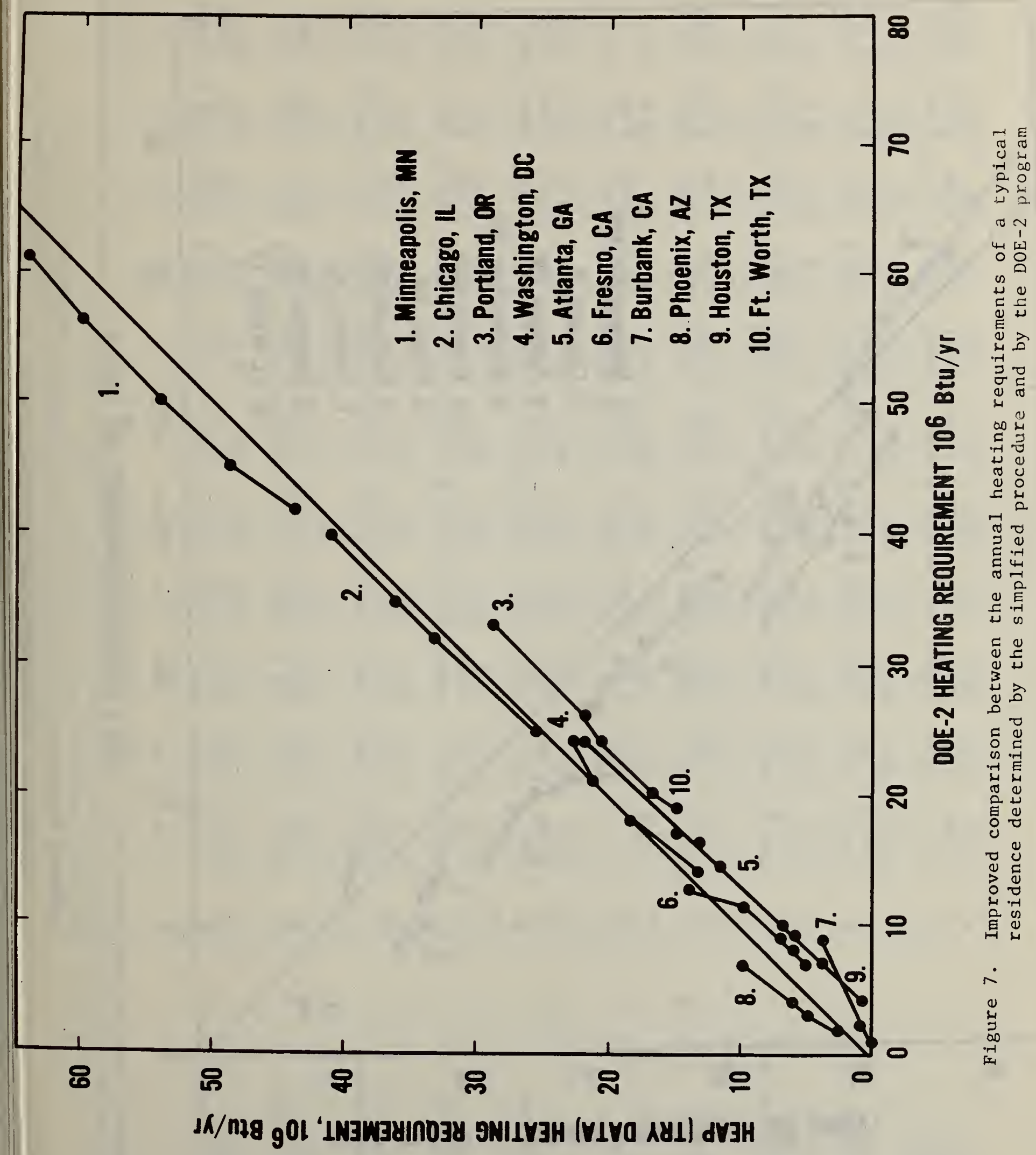




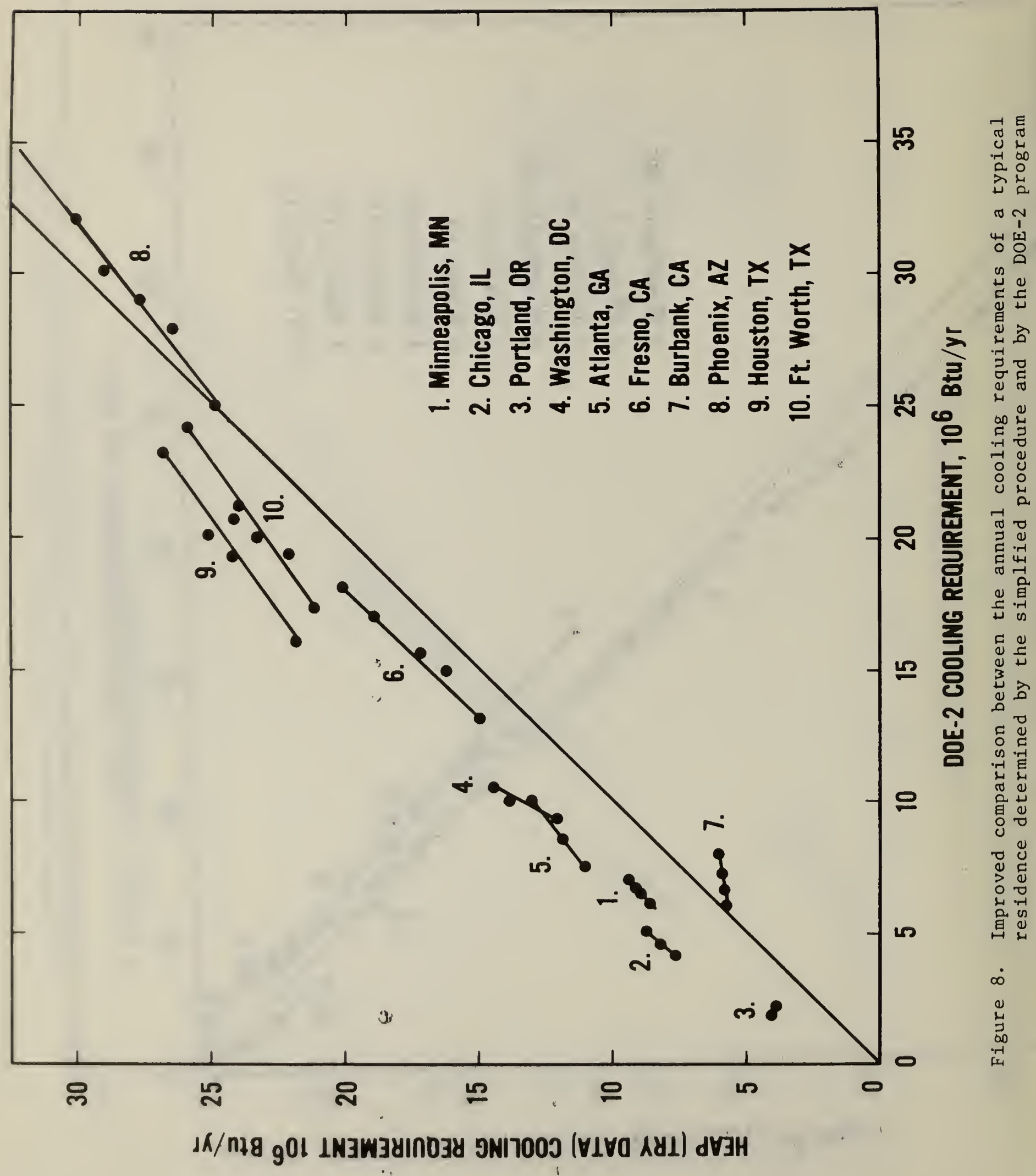




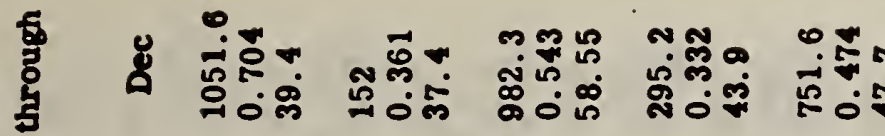

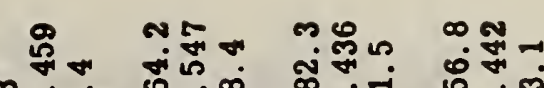

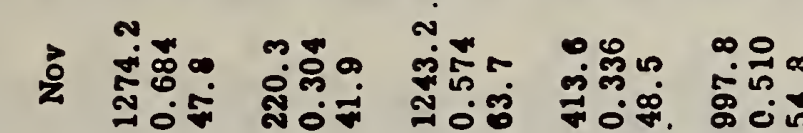

5

运-

ำ

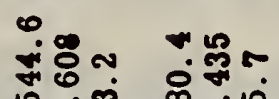

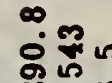

๘

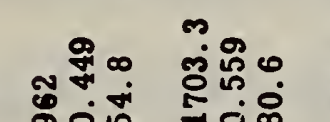

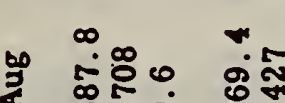

赵

กัं

吾.

ஸ்க

\section{$\infty$}

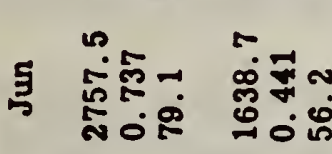

(1)

พี่

象通

đัष

กี่ กับ

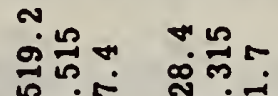

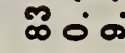

乌ீं

สं

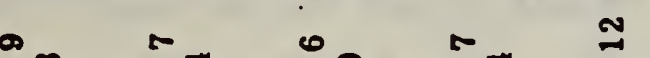

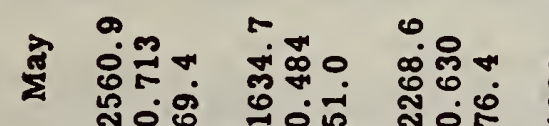

ใ

$\ln 2$

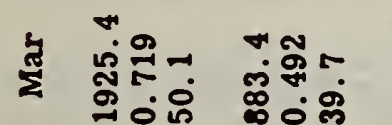

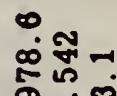

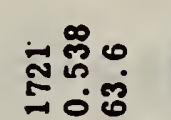

:

กิ่

○శ్

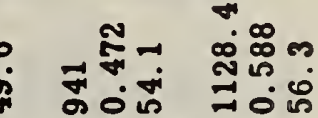

a

म

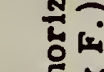

(5)

ธิ

50

实

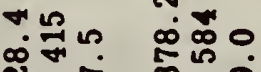

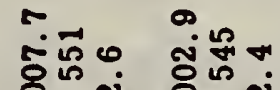

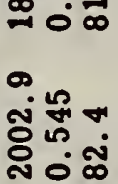

मह

भั

ร。요

น̊ํำ

\section{$m$}

ชั่

$\infty \quad \infty$

นึ

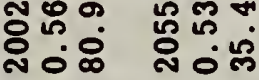

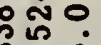

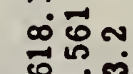

(4)

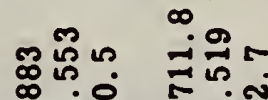

$\infty$

कृ

용 n

$\infty \infty$

จัฒ

2 50

ถึడ

茫范

귱

n.

เి

ํํㅇ 용

엉요 ลํㄴ

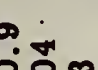

\section{ง}

in 00

政

กับ

承穴

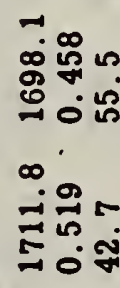

$\infty$

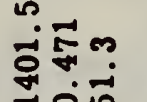

ธี้ํำ สํำ

กิ่

过

: 0

nom

๑ீ.

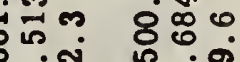




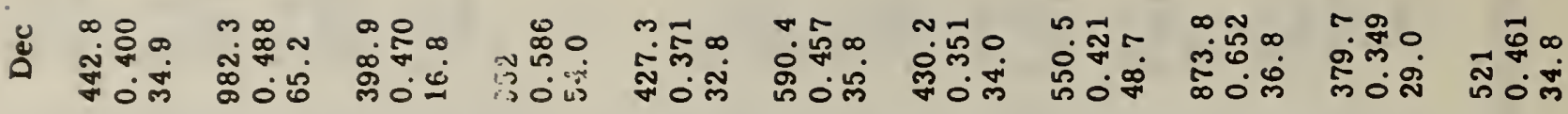

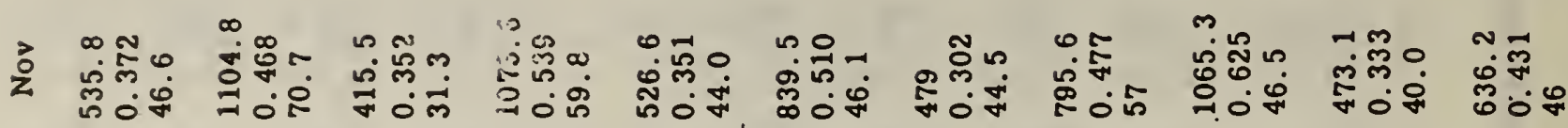

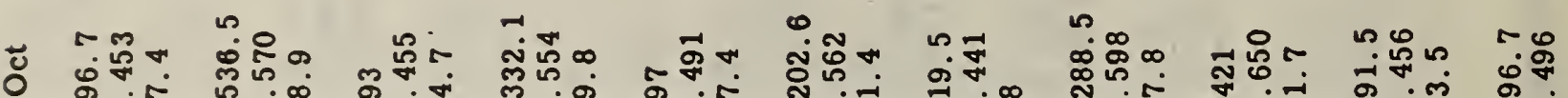
范

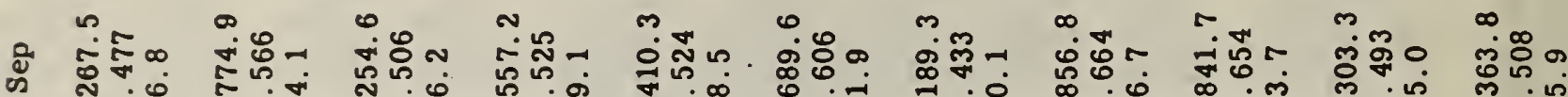
范 दै

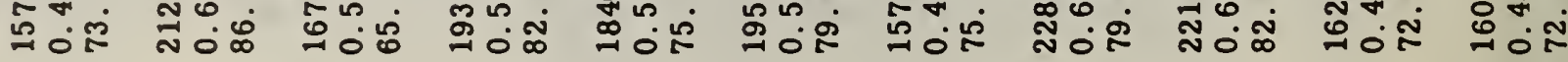

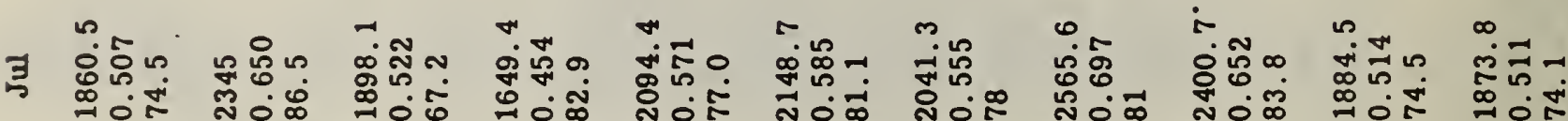
5 క

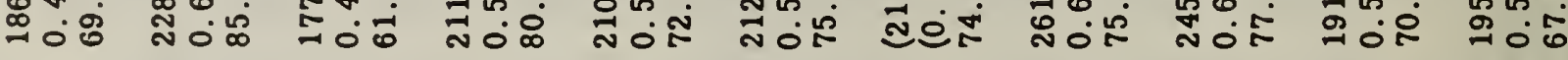

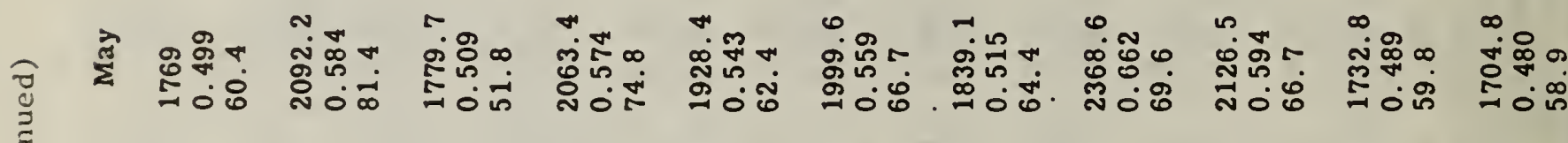

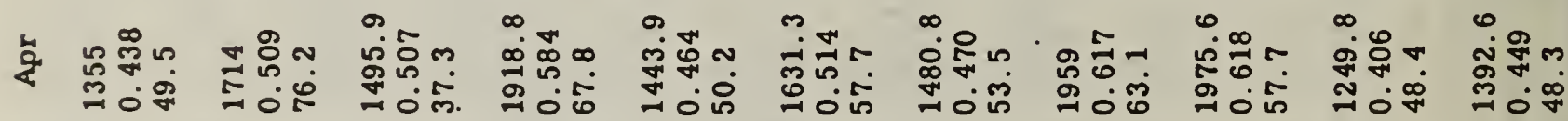

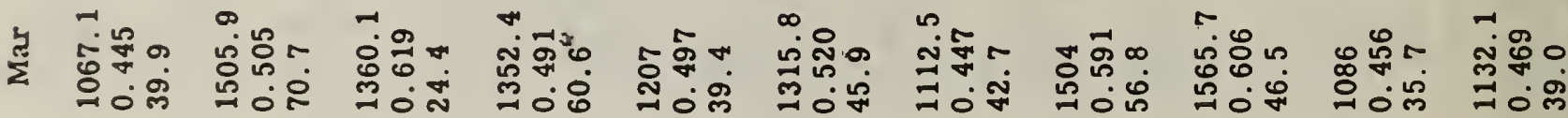

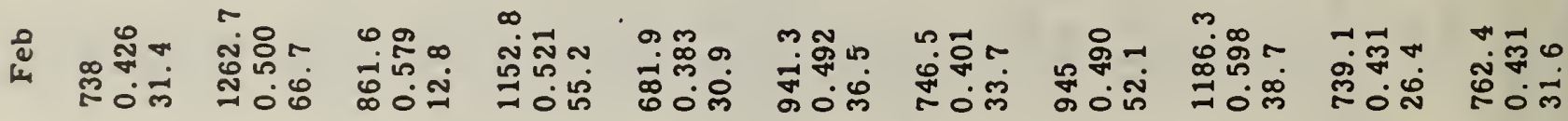

స్

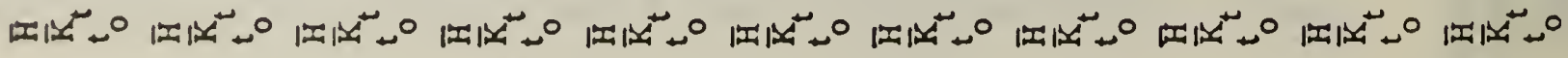

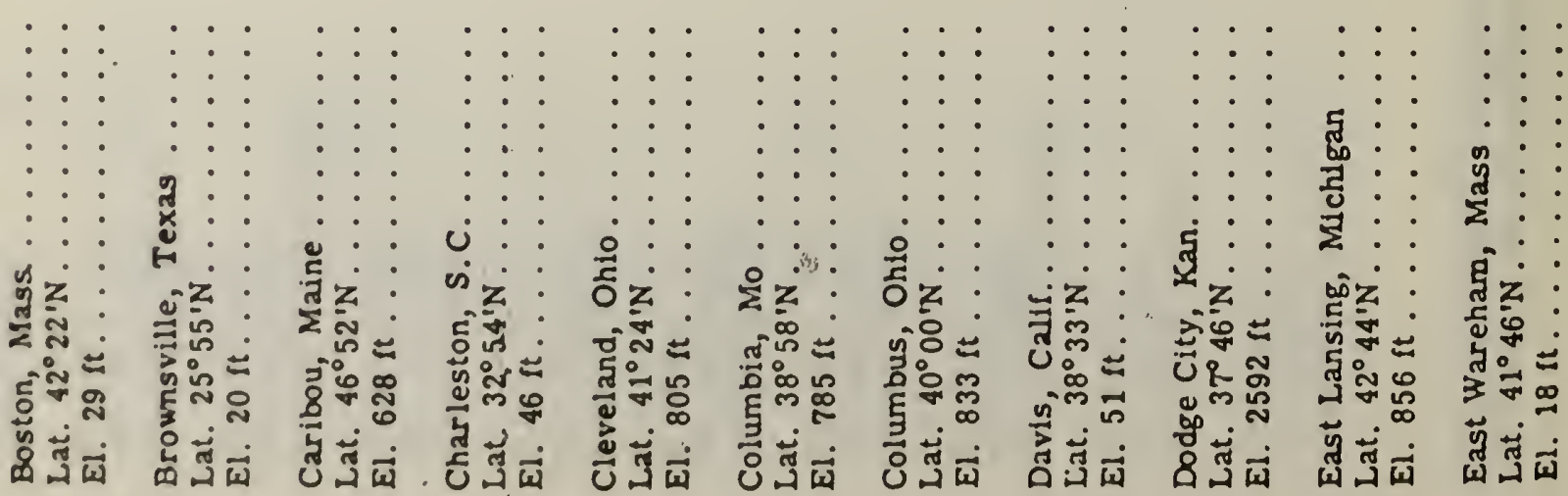




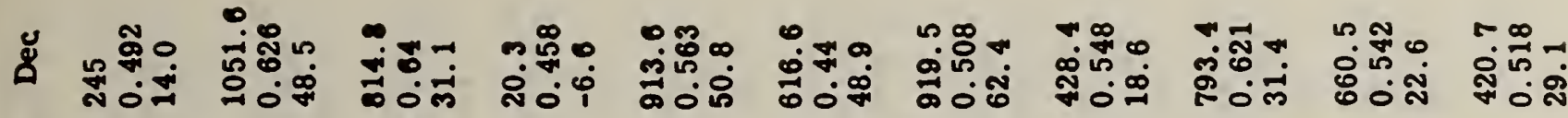

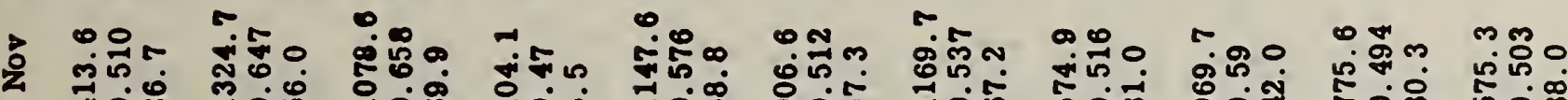

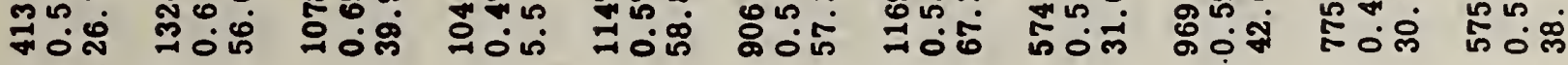

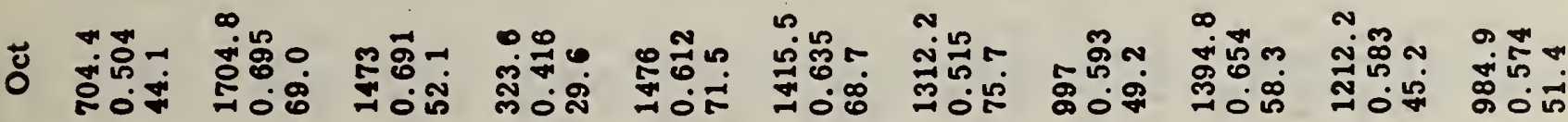

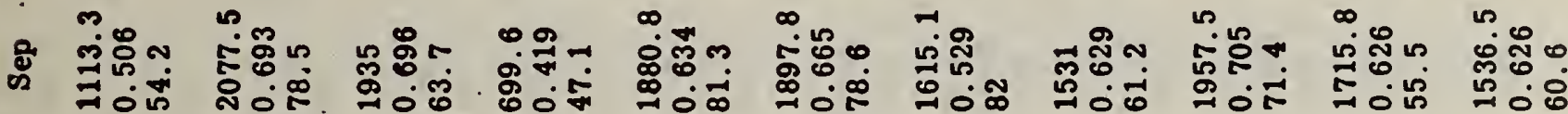

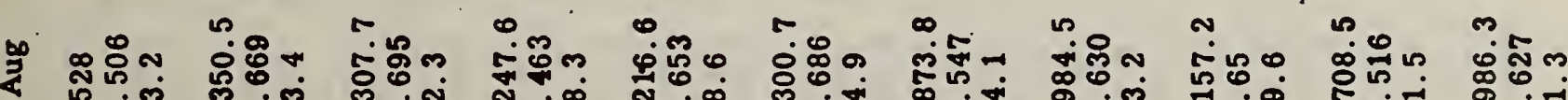
กี่

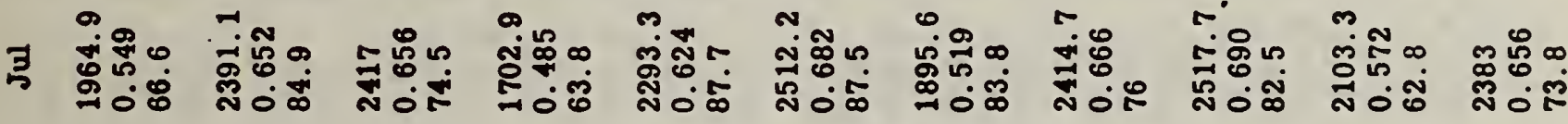

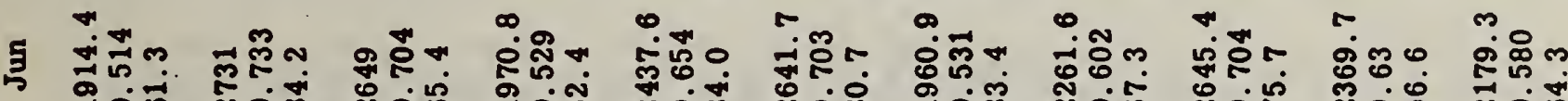
- 0 -

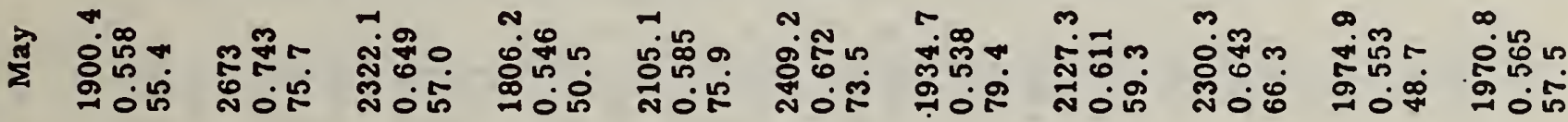

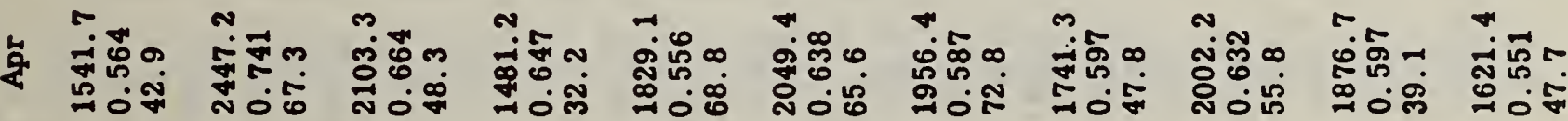

క

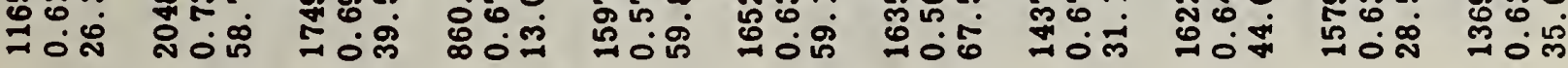
\& 话

స్

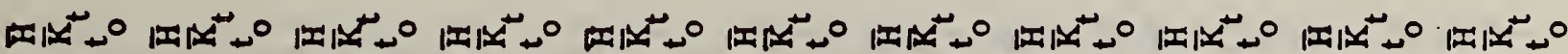

岁: : :

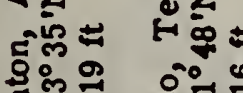

రํำ

文: 岁

Et

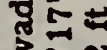

ก

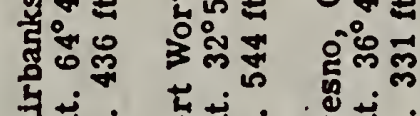

乙 ले

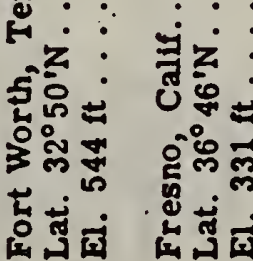

空:

类:

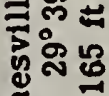

递

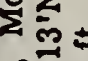

起客

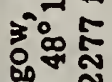

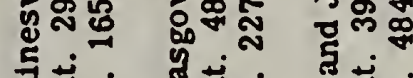

है

웅.

르: :

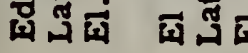

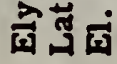
क्षाओ 


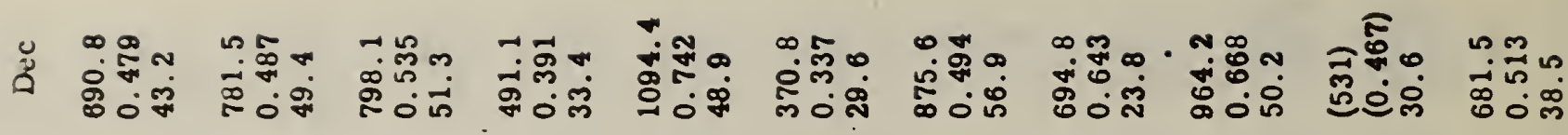

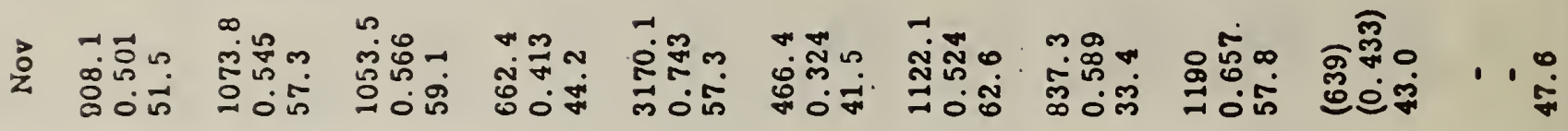

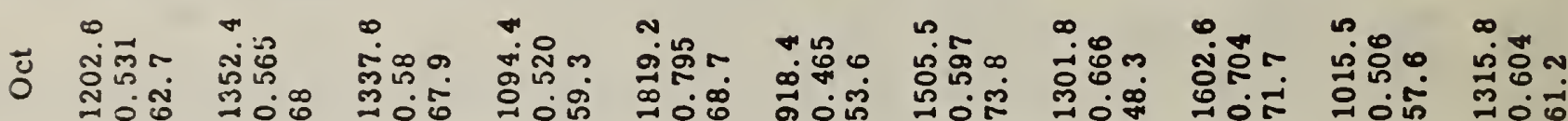
भ ॠ ๓ चั

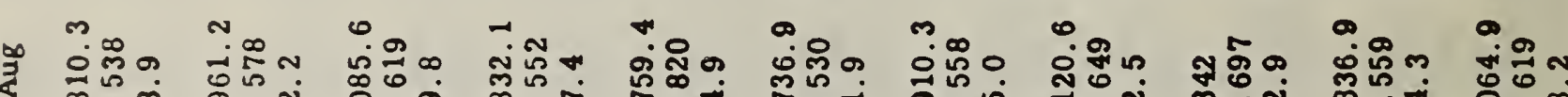
द క

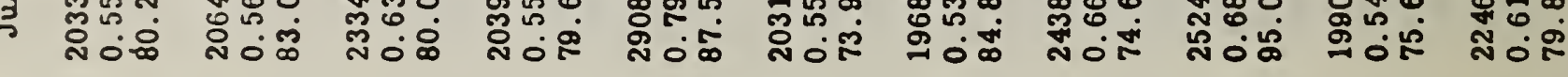

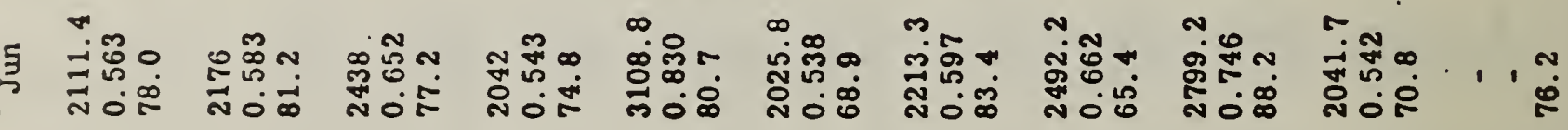

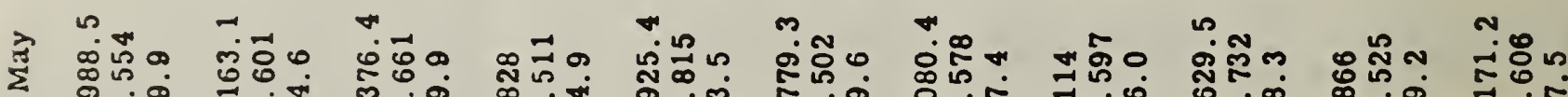

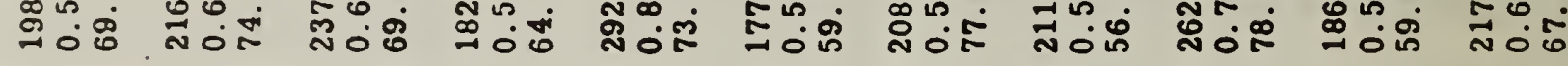

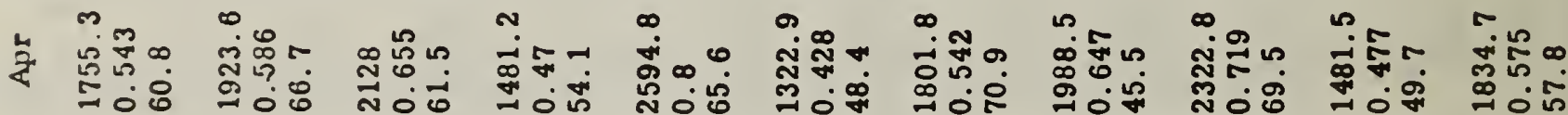

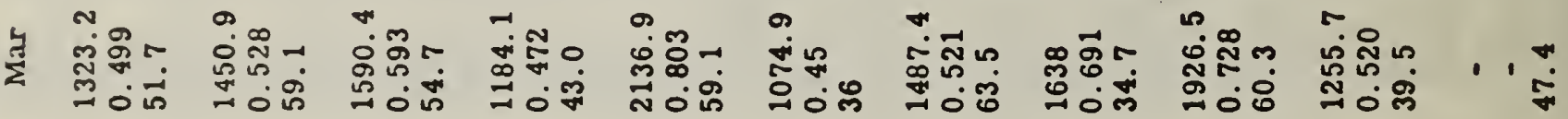

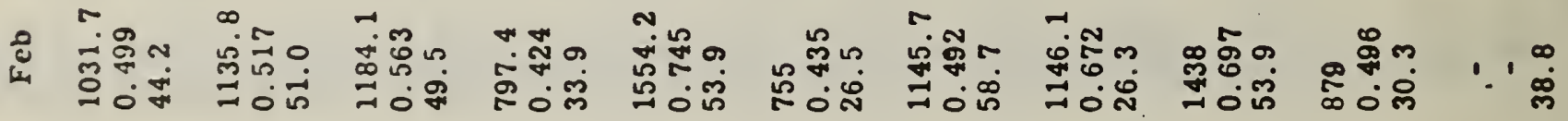

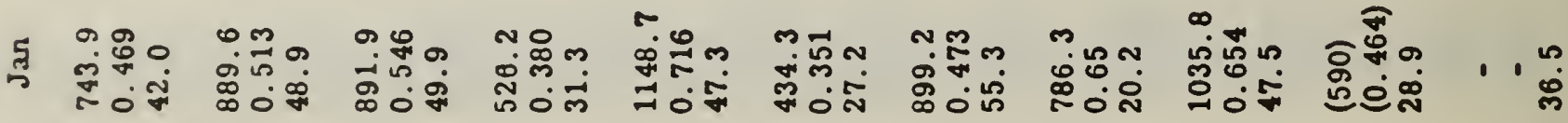

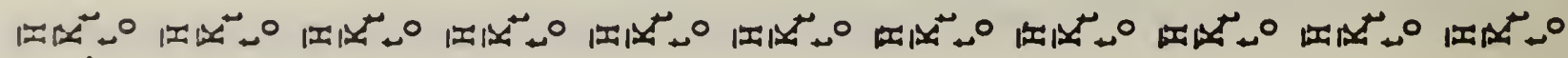
:
a
:

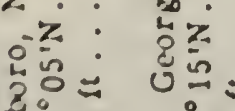
:
ษั
sic

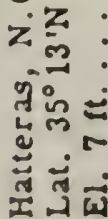

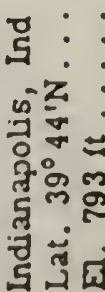

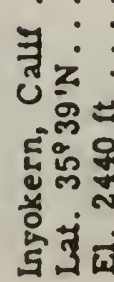

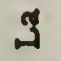
giz: : $\dot{z} z:$

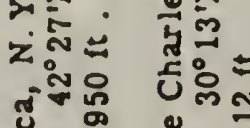
ํํำ

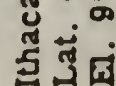

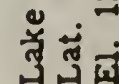

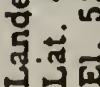
b:
z

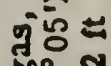

引实闵

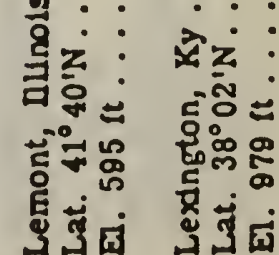




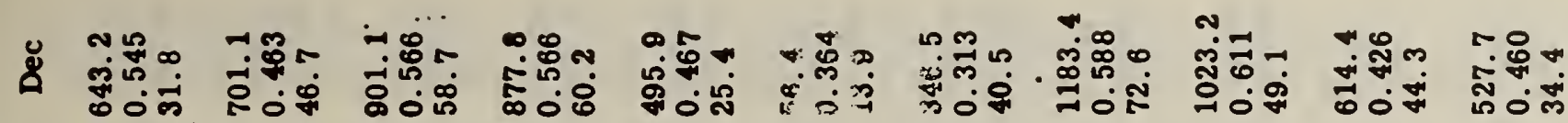
Z

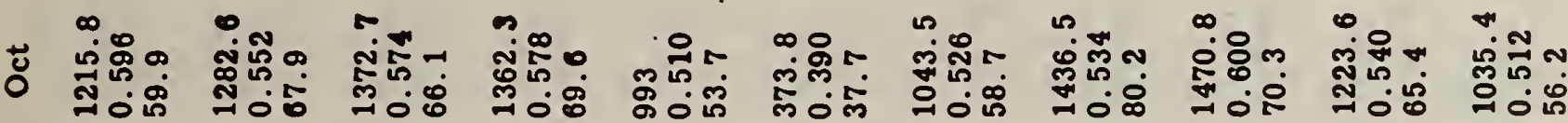

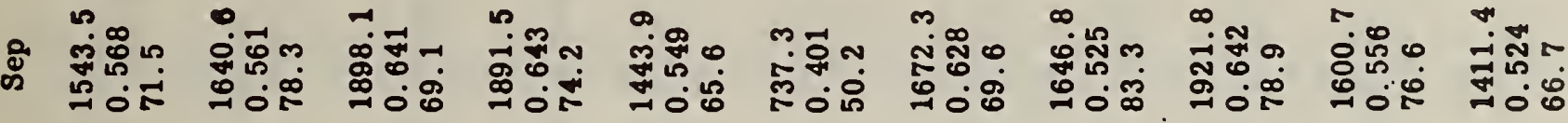

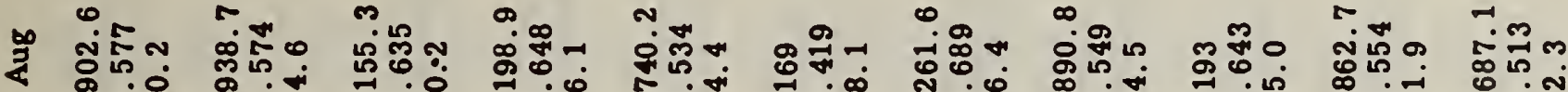

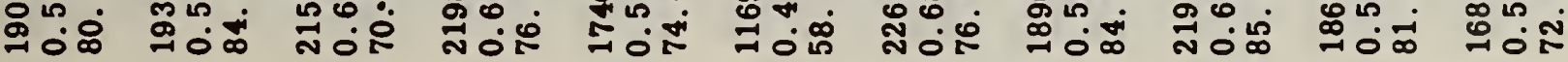

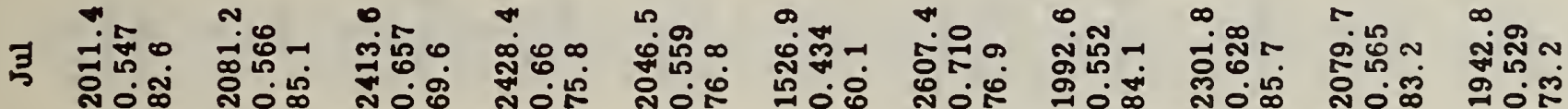

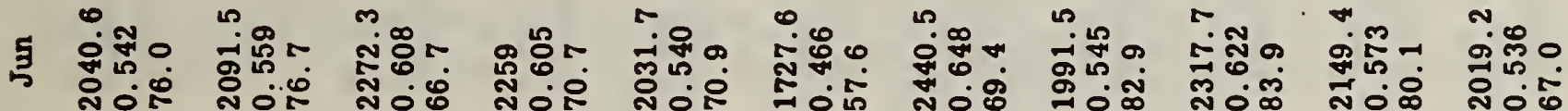

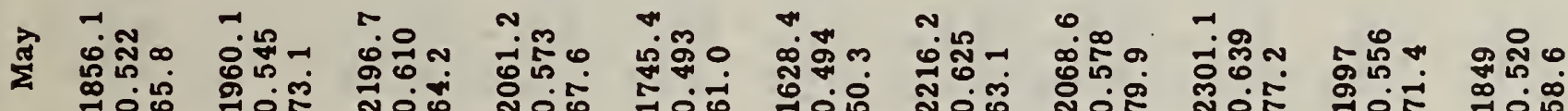

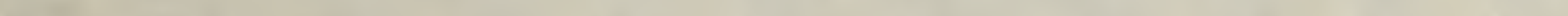

द 月ั

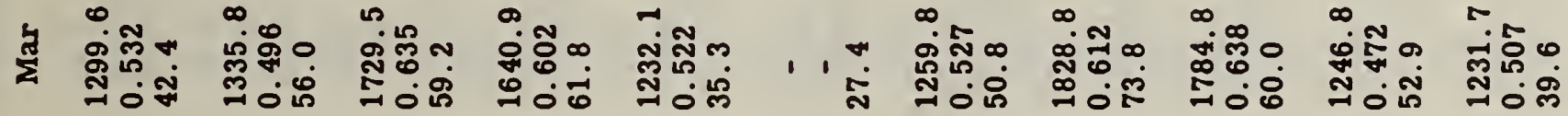

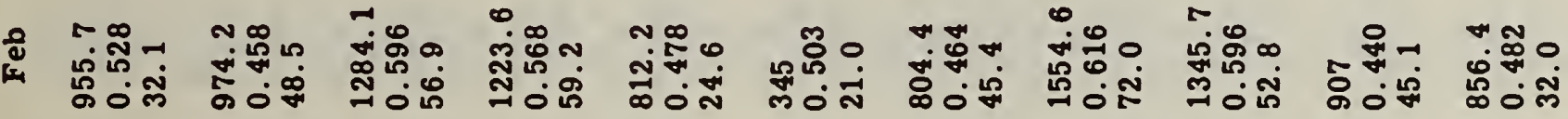

采

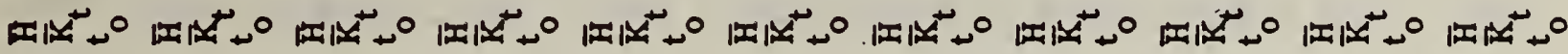

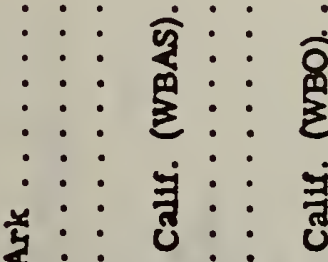

: $:$ 录:

远:

光

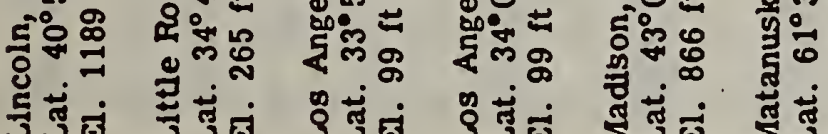

$:: \mathbb{8}_{0}:$

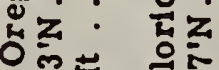

กับ

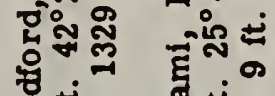

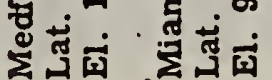

$::$

ख़े⿺

Fis

कृष्ठ

胥节四

\section{(1)}


ل Z ப

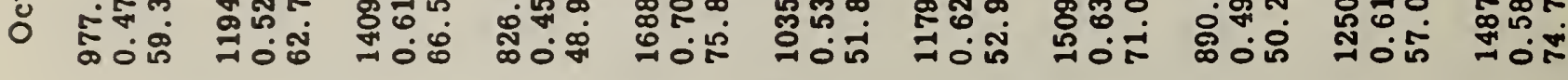
\%

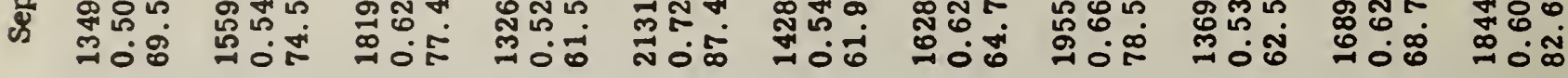

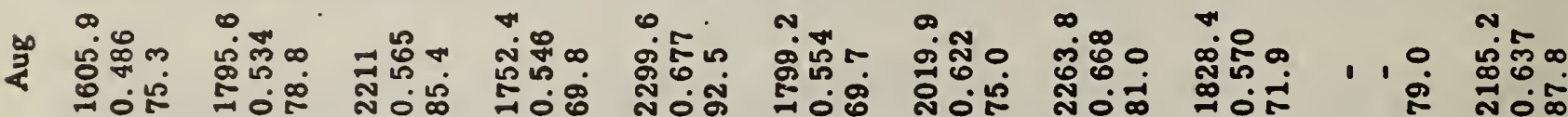

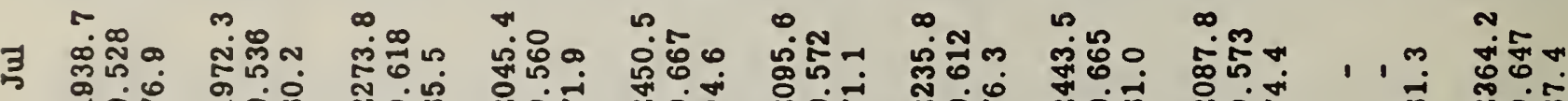

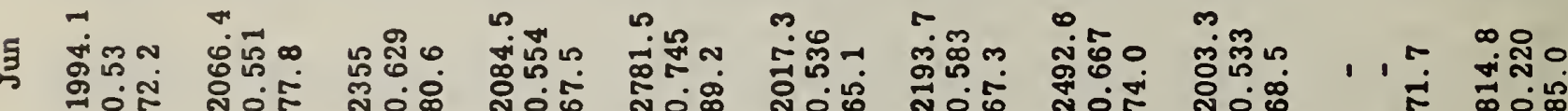

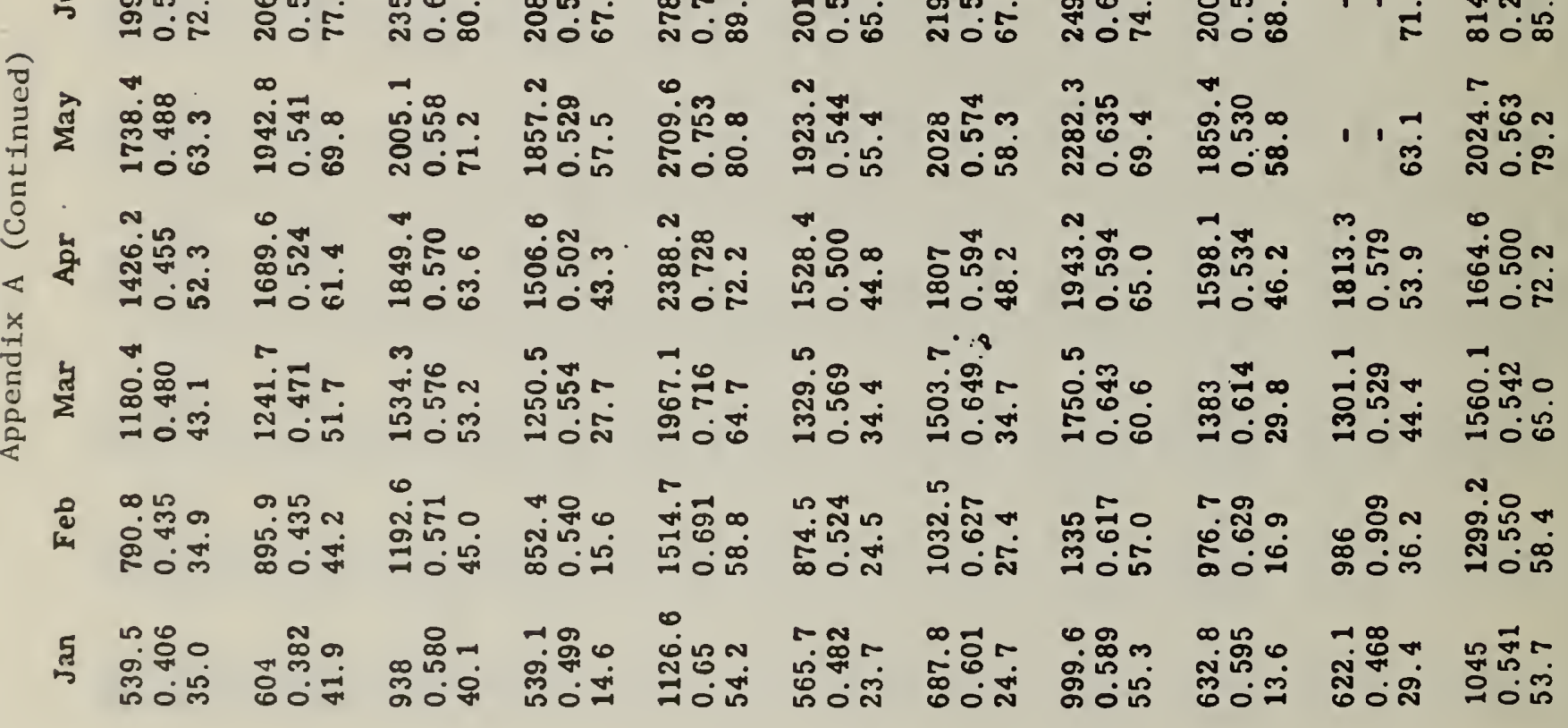

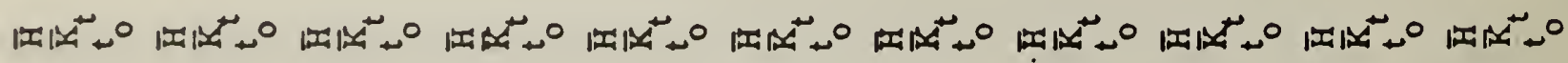

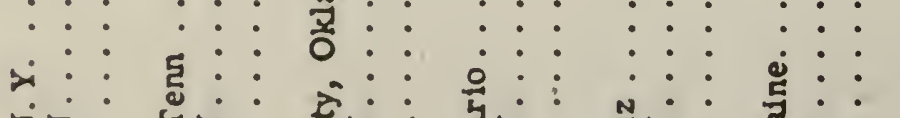

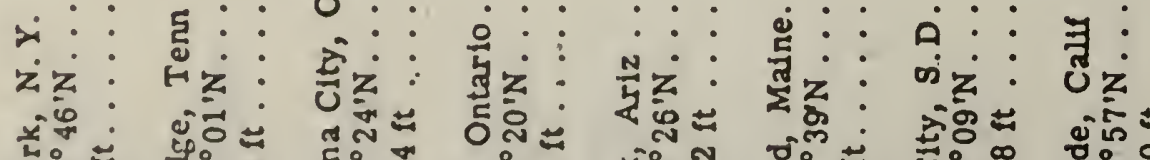

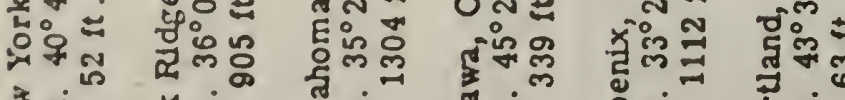

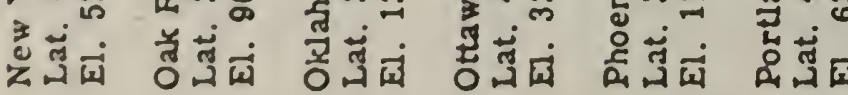

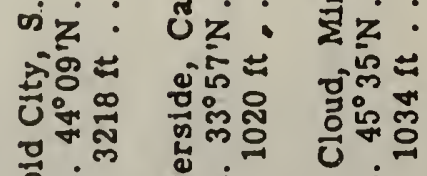

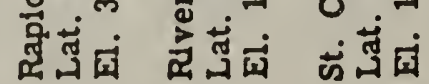

รేं:

ร:: Uัँ 격유뉴

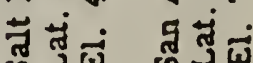




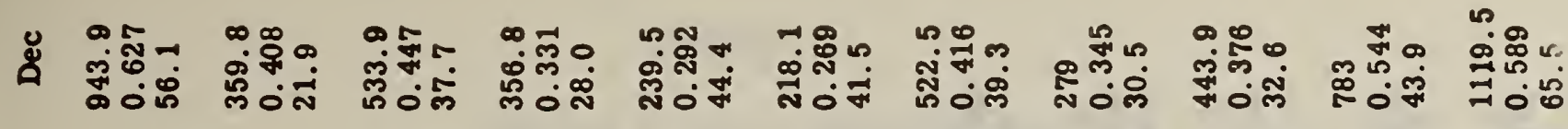

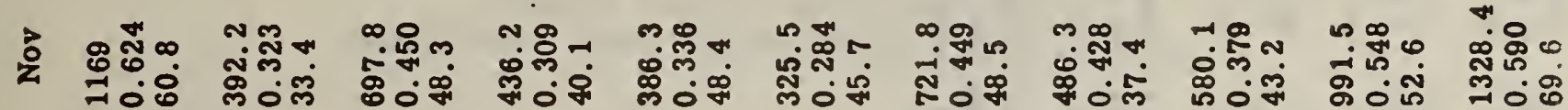
ப

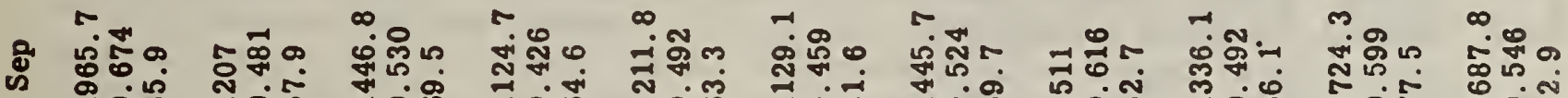

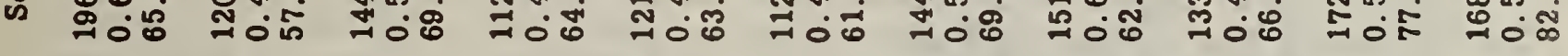

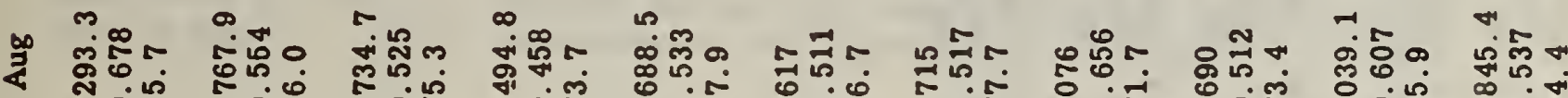
ส้ำ

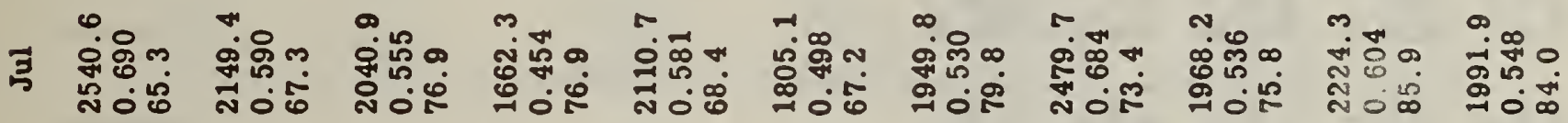

5 节

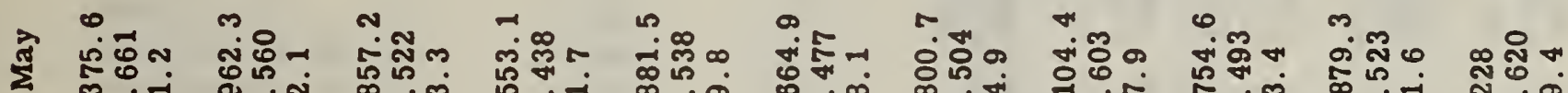

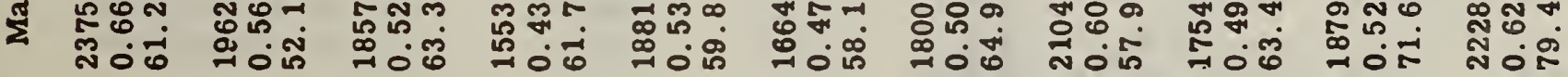
द厶

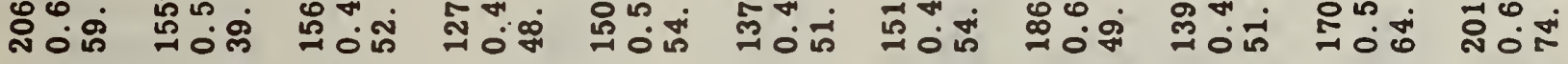

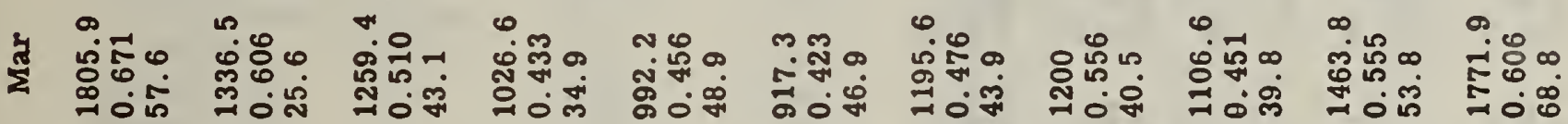

离

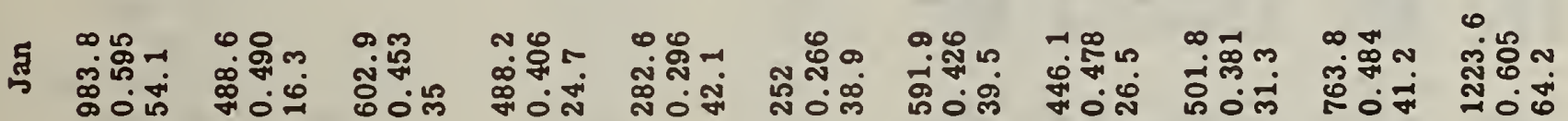

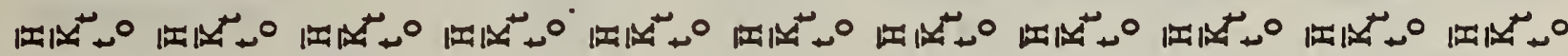

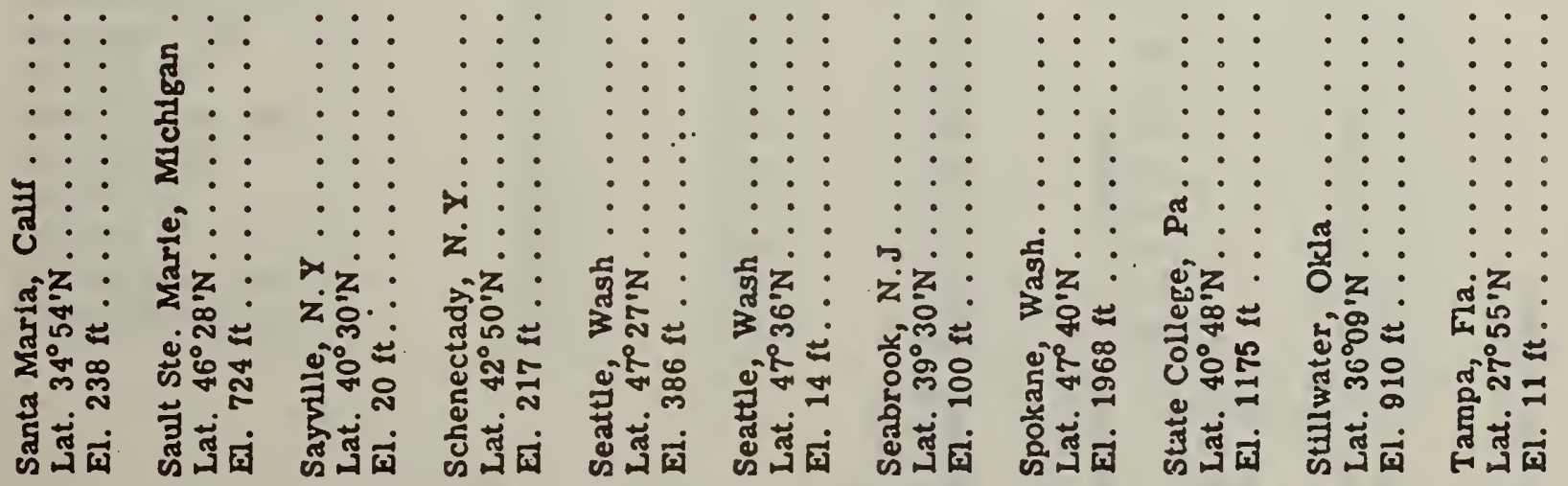




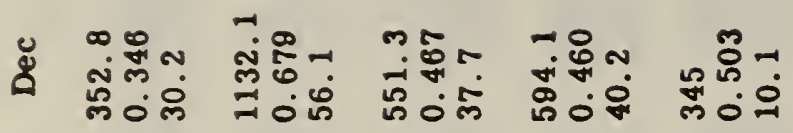

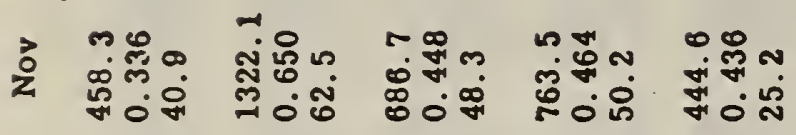

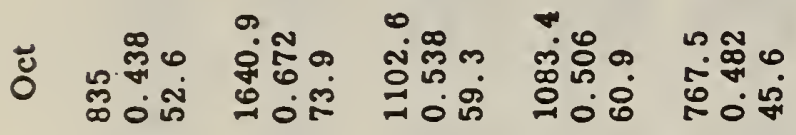

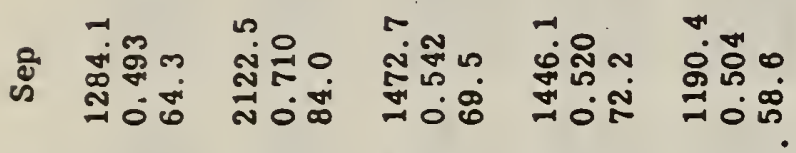

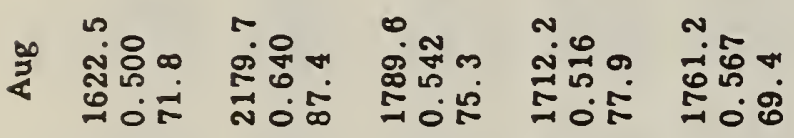

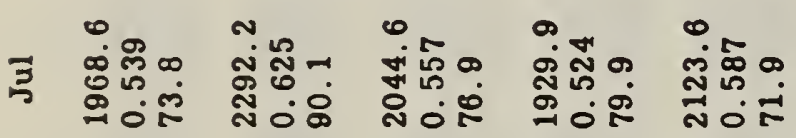

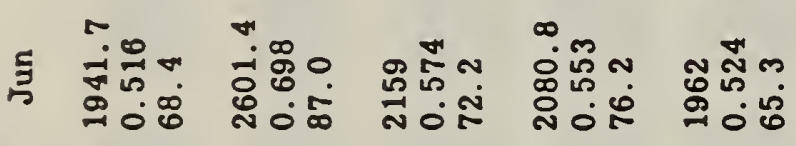

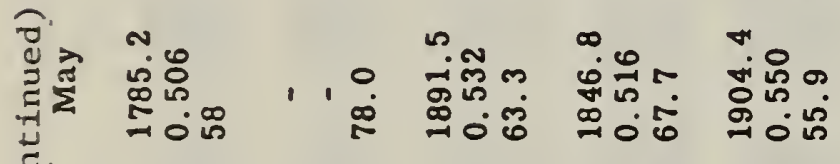

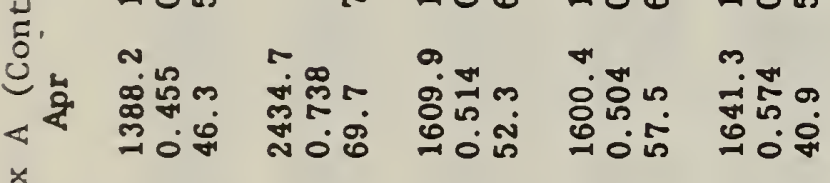

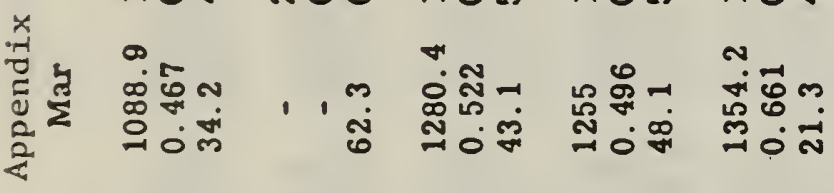

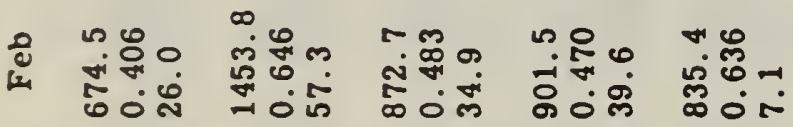

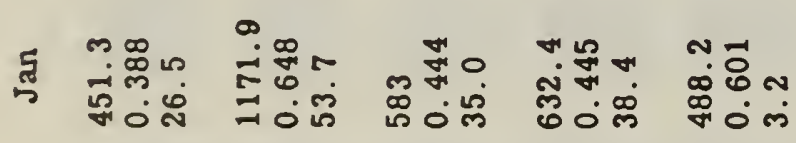

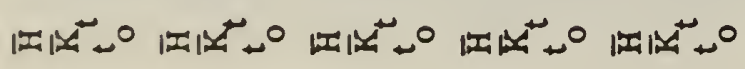

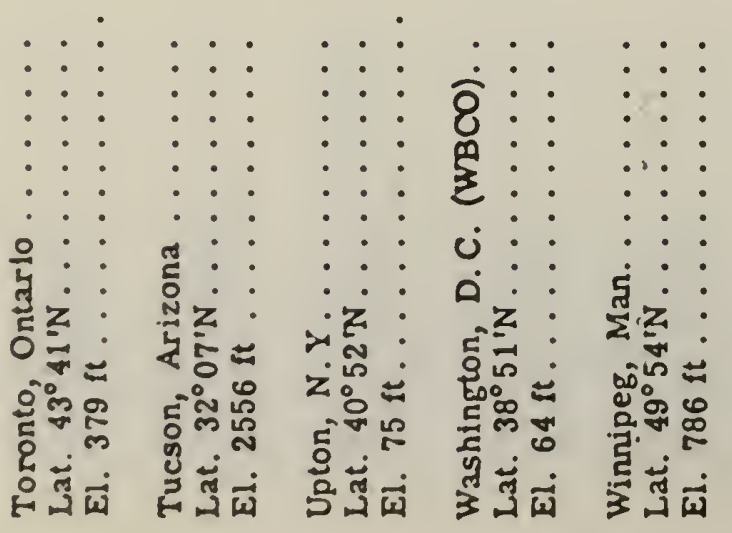




\section{AVERAGE EARTH TEMPERATURE FOR UNDERGROUND HEAT DISTRIBUTION SYSTEM DESIGN}

The following list presents the average earth temperature from 0 to 10 feet below the surface for the four seasons of the year and for the whole year for the indicated locals. The temperatures were computed on the basis of the method described in the 1965 ASHRAE technical paper entitled "Earth Temperature and Thermal Diffusivity at Selected Stations in the United States" by T. Kusuda and P. R. Achenbach (in ASHRAE Transactions, Volume 71, Part I, p. 61, 1965) using the monthly average air temperatures published by the U.S. Weather Bureau for the listed localities in the United States. Earth temperatures are expressed in fahrenheit degrees.

\begin{tabular}{lrrrrr} 
& & Winter & Spring & Summer & Autumn Annual \\
\hline
\end{tabular}

Alabama

Anniston AP $^{a}$

Birmingham AP

Mobile AP

Mobile $\mathrm{CO}^{\mathrm{b}}$

Montgomery AP

Montgomery CO

Arizona

Bisbee COOPC

Flagstaff AP

Ft Huachuca (proving ground)

Phoenix AP

Phoenix CO

Prescott AP

Tucson AP

Winslow AP

Yuma AP

Arkansas

Fort Smith AP

Little Rock AP

Texarkana AP

California

Bakersfield AP

Beaumont $\mathrm{CO}$

Bishop AP

Blue Canyon AP

Burbank AP

Eureka CO

Fresno AP

Los Angeles AP

Los Angeles CO
55.

54.

61 .

61.

58.

59.

55.

35 .

55.

60.

61.

46.

59.

45.

65 .

52.

53.

56.

56.

53.

47.

43.

58.

50.

54.

58.

60 .
58.

58.

63.

64.

61.

62.

58.

39.

58.

64.

65.

49.

62.

49.

69.

56.

57.

60 .

60.

56.

51.

46.

60.

51.

58.

59.

61.
70.

71.

74.

75.

73.

74.

70.

54.

71.

79.

80.

65.

76.

65.

84.

72.

72.

74.

74.

67.

65.

58.

68.

54.

72.

64.

68.
67.

68.

71.

72.

70 .

71.

67.

50.

62.

45.

68.

63.

75.69.

76.70.

61. 55 .

73.68.

61.55.

80 . 75 .

68.

62.

$68 . \quad 62$.

$71 . \quad 65$.

$\begin{array}{ll}70 . & 65 . \\ 64 . & 60 .\end{array}$

61. 56.

55.550.

66.63.

54.552.

68.63.

$63 . \quad 61$.

66. 64. 


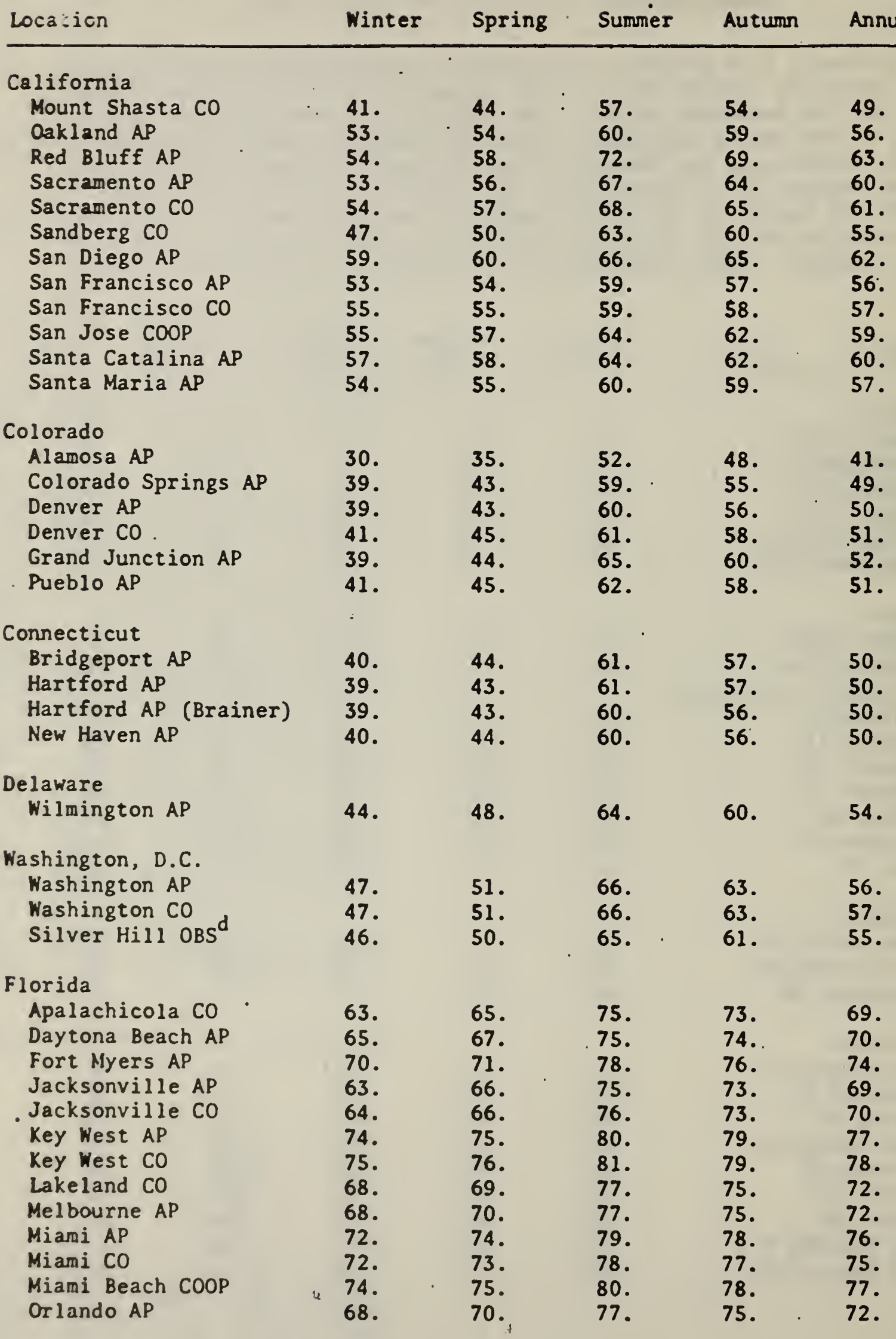




\section{Florida \\ Pensacola CO \\ Tallahassee AP \\ Tampa AP \\ West Palm Beach}

\section{Georgia}

Albany AP

Athens AP

Atlanta AP

Atlanta CO

Augusta AP

Columbus AP

Macon AP

Rome AP

Savannah AP

Thomasville CO

Valdosta AP

\section{Idaho}

Boise AP

Idaho Falls $46 \mathrm{~W}$

Idaho Falls $42 \mathrm{~N} \mathrm{~W}$

Lewiston AP

Pocatello AP

Salmon $C O$

\section{Illinois}

Cairo CO

Chicago AP

Joliet AP

Moline AP

Peoria AP

Springfield AP

Springfield CO

\section{Indiana}

Evansville AP

Fort Wayne AP

Indianapolis AP

Indianapolis $C O$

South Bend AP

Terre Haute AP

Iowa

Burlington AP

Charles City CO

Davenport CO

Des Moines AP

Des Moines C.O
62.

61.

68.

71.

60.

54.

54.

54.

56.

56.

58.

53.

60.

62.

61.

40.

30 .

28.

42.

35.

32.

49.

38.

37.

38.

39.

41.

43.

47.

39.

41.

43.

38.

42.

39.

33.

39.

37.

38.
64.

64.

69.

73.

63.

58.

57.

57.

59.

59.

61.

56.

63.

64.

64.

44.

35.

33.

46.

40.

37.

53.

43.

42.

43.

44.

45.

47.

51.

43.

46.

48.

42.

47.

44.

38.

44.

42.

43.
74.

74.

77.

79.

75.

71.

70.

70.

72.

72.

74.

70.

74.

74.

74.

62.

55.

54.

63.

59.

56.

70.

62.

61.

62.

63.

64.

66.

67.

61.

64.

65.

61.

65.

64.

60.

64.

63.

64.
72.

72.

75.

77 .

68.

68.

72.

75.

67.

63.

62.

62.

64.

64.

66.

61.

67.

68.

68.

72.

72.

58.

51.

42.

41 .

49.

59.

55.

52.

52.

47.

44.

66.

60.

57.

56.

58.

58.

60.

62.

50.

49.

50.

51.

52.

54.

57.

50.

52.

54.

49.

53.

56.

60.

51.

46.

51 .

50.

51 . 


\begin{tabular}{|c|c|c|c|c|c|}
\hline Location & Winter & Spring & Summer & Autumn & Annu \\
\hline \multicolumn{6}{|l|}{ Iowa } \\
\hline $\begin{array}{l}\text { Dubuque AP } \\
\text { Sioux City AP } \\
\text { Waterloo AP }\end{array}$ & $\begin{array}{l}34 \\
35 \\
35\end{array}$ & $\begin{array}{l}39 . \\
40 . \\
40 .\end{array}$ & $\begin{array}{l}60 . \\
62 . \\
61\end{array}$ & $\begin{array}{l}55 . \\
57 . \\
56 .\end{array}$ & $\begin{array}{l}47 . \\
49 . \\
48\end{array}$ \\
\hline \multicolumn{6}{|l|}{ Kansas } \\
\hline $\begin{array}{l}\text { Concordia CO } \\
\text { Dodge City AP } \\
\text { Goodland AP } \\
\text { Topeka AP } \\
\text { Topeka CO } \\
\text { Wichita AP }\end{array}$ & $\begin{array}{l}42 . \\
43 . \\
38 \\
43 . \\
44 \\
45\end{array}$ & $\begin{array}{l}47 . \\
48 . \\
43 . \\
47 . \\
49 . \\
50 .\end{array}$ & $\begin{array}{l}67 . \\
67 . \\
62 . \\
66 . \\
68 . \\
68 .\end{array}$ & $\begin{array}{l}62 . \\
62 . \\
57 . \\
62 . \\
63 . \\
64\end{array}$ & $\begin{array}{l}54 . \\
55 \\
50 \\
55 \\
56 \\
57\end{array}$ \\
\hline \multicolumn{6}{|l|}{ Kentucky } \\
\hline $\begin{array}{l}\text { Bowling Green AP } \\
\text { Lexington AP } \\
\text { Louisville AP } \\
\text { Louisville CO }\end{array}$ & $\begin{array}{l}47 . \\
44 \\
46 \\
47\end{array}$ & $\begin{array}{l}51 . \\
48 . \\
50 . \\
51\end{array}$ & $\begin{array}{l}67 . \\
65 \\
67 \\
67\end{array}$ & $\begin{array}{l}63 . \\
61 . \\
63 . \\
64 .\end{array}$ & $\begin{array}{l}57 . \\
54 \\
56 \\
57\end{array}$ \\
\hline \multicolumn{6}{|l|}{ Louisiana } \\
\hline $\begin{array}{l}\text { Baton Rouge AP } \\
\text { Burrwood CO } \\
\text { Lake Charles AP } \\
\text { New Orleans AP } \\
\text { New Orleans CO } \\
\text { Shreveport AP }\end{array}$ & $\begin{array}{l}61 . \\
65 \\
61 \\
63 \\
64 \\
58\end{array}$ & $\begin{array}{l}63 . \\
67 . \\
64 . \\
65 . \\
66 . \\
61 .\end{array}$ & $\begin{array}{l}74 . \\
77 \\
75 \\
75 \\
77 . \\
75\end{array}$ & $\begin{array}{l}72 . \\
74 . \\
73 . \\
73 . \\
74 . \\
72 .\end{array}$ & $\begin{array}{l}67 . \\
71 . \\
68 \\
69 \\
70 \\
66\end{array}$ \\
\hline \multicolumn{6}{|l|}{ Maine } \\
\hline $\begin{array}{l}\text { Caribou AP } \\
\text { Eastport CO } \\
\text { Portland AP }\end{array}$ & $\begin{array}{l}24 . \\
33 \\
33\end{array}$ & $\begin{array}{l}29 . \\
37 \\
38\end{array}$ & $\begin{array}{l}50 . \\
51 . \\
56 .\end{array}$ & $\begin{array}{l}45 \\
48 \\
51\end{array}$ & $\begin{array}{l}37 . \\
42 \\
44\end{array}$ \\
\hline Maryland & ; & & - & & \\
\hline $\begin{array}{l}\text { Baltimore AP } \\
\text { Baltimore CO } \\
\text { Frederick AP }\end{array}$ & $\begin{array}{l}45 . \\
47 . \\
44 .\end{array}$ & $\begin{array}{l}49 . \\
51 . \\
48 .\end{array}$ & $\begin{array}{l}65 \\
67 \\
65\end{array}$ & $\begin{array}{l}61 . \\
63 \\
61\end{array}$ & $\begin{array}{l}55 \\
57 \\
55\end{array}$ \\
\hline \multicolumn{6}{|l|}{ Massachusetts } \\
\hline $\begin{array}{l}\text { Boston AP } \\
\text { Nantucket AP } \\
\text { Pittsfield AP } \\
\text { Worcester AP }\end{array}$ & $\begin{array}{l}41 . \\
41 . \\
34 . \\
36 .\end{array}$ & $\begin{array}{l}44 . \\
44 . \\
38 . \\
40 .\end{array}$ & $\begin{array}{l}61 . \\
57 \\
55 \\
58\end{array}$ & $\begin{array}{l}57 . \\
54 . \\
51 \\
54\end{array}$ & $\begin{array}{l}51 \\
49 \\
44 \\
47\end{array}$ \\
\hline \multicolumn{6}{|l|}{ Michigan } \\
\hline $\begin{array}{l}\text { Alpena CO } \\
\text { Detroit Willow Run AP } \\
\text { Detroit City AP } \\
\text { Escanaba CO } \\
\text { Flint AP } \\
\text { Grand Rapids AP }\end{array}$ & $\begin{array}{l}33 . \\
38 . \\
38 . \\
30 . \\
36 . \\
36\end{array}$ & $\begin{array}{l}37 . \\
42 . \\
43 . \\
35 . \\
40 . \\
40 .\end{array}$ & $\begin{array}{l}54 . \\
60 . \\
60 . \\
53 . \\
58 . \\
58 .\end{array}$ & $\begin{array}{l}50 . \\
56 . \\
56 . \\
49 . \\
54 . \\
54 .\end{array}$ & $\begin{array}{l}43 . \\
49 . \\
49 \\
42 . \\
47 \\
47\end{array}$ \\
\hline
\end{tabular}




\section{Michigan}

Grand Rapids CO

East Lansing CO

Marquette CO

Muskecon AP

Sault Ste Marie AP
Minnesota

Crookston COOP

Duluth AP

Duluth CO

International Falls

Minneapolis AP

Rochester AP

Saint Cloud AP

Saint Paul AP

Mississippi

. Jackson AP

Meridian AP

Vicksburg CO

Missouri

Columbia AP

Kansas City AP

Saint Joseph AP

Saint Louis AP

Saint Louis CO

Springfield AP

\section{Montana}

Billings AP

Butte AP

Glasgow AP

Glasgow CO

Great Falls AP

Harve $\mathrm{CO}$

Helena AP

Helena $C O$

Kalispell AP

Miles City AP

Missoula AP

Nebraska

Grand Island AP

Lincoln AP

Lincoln CO University

Norfolk AP

North Platte AP

Onaha AP
38.

36.

31.

36.

28.

42.

40.

35 .

40.

32 .

25.

25.

26.

22.

32 .

31.

28.

32 .

57

57.

58.

43.

44 .

42 .

45 .

46 .

45 .

35.

27.

27.

28.

34.

31.

31.

32.

32 .

32.

33.

38.

39.

40.

35 .

37.

39.

31.

30.

31.

27.

37.

36.

33.

37.

61.

60.

61.

48.

49.

47.

49.

50.

49.

40.

31.

33.

34.

38.

36.

36.

36.

37.

37.

37.

43.

44.

45.

40 .

42.

44.
60.

58.

53.

57.

51.

73.

72.

74.

55.

52.

52.

51.

60 .

58.

56.

60.

66.

68.

67.

67.

68.

66.
56.

54.

49.

53.

47.

49.

47.

42 .

47.

39.

$\begin{array}{ll}49 . & 40 . \\ 47 . & 38 . \\ 47 . & 39 . \\ 45 . & 36 . \\ 54 . & 46 . \\ 53 . & 44 . \\ 51 . & 42 . \\ 54 . & 46 .\end{array}$

70.

69.

65.

64.

71.

66.

62.

64.

62.

63.

64.

62.

55.

56.

54.

56.

57.

56.

$\begin{array}{lll}59 . & 55 . & 47 . \\ 50 . & 45 . & 38 .\end{array}$

56.52.

$57.52 . \quad 43$.

56.52.

$57 . \quad 52 . \quad 44$.

55.53.

55.53.

54.50 .43$.

59.54.

56.51.

$\begin{array}{lll}64 . & 59 . & 51 . \\ 64 . & 60 . & 52 .\end{array}$

65.61 .53$.

62.57.

62. $57 . \quad 49$.

$65 . \quad 60 . \quad 52$. 


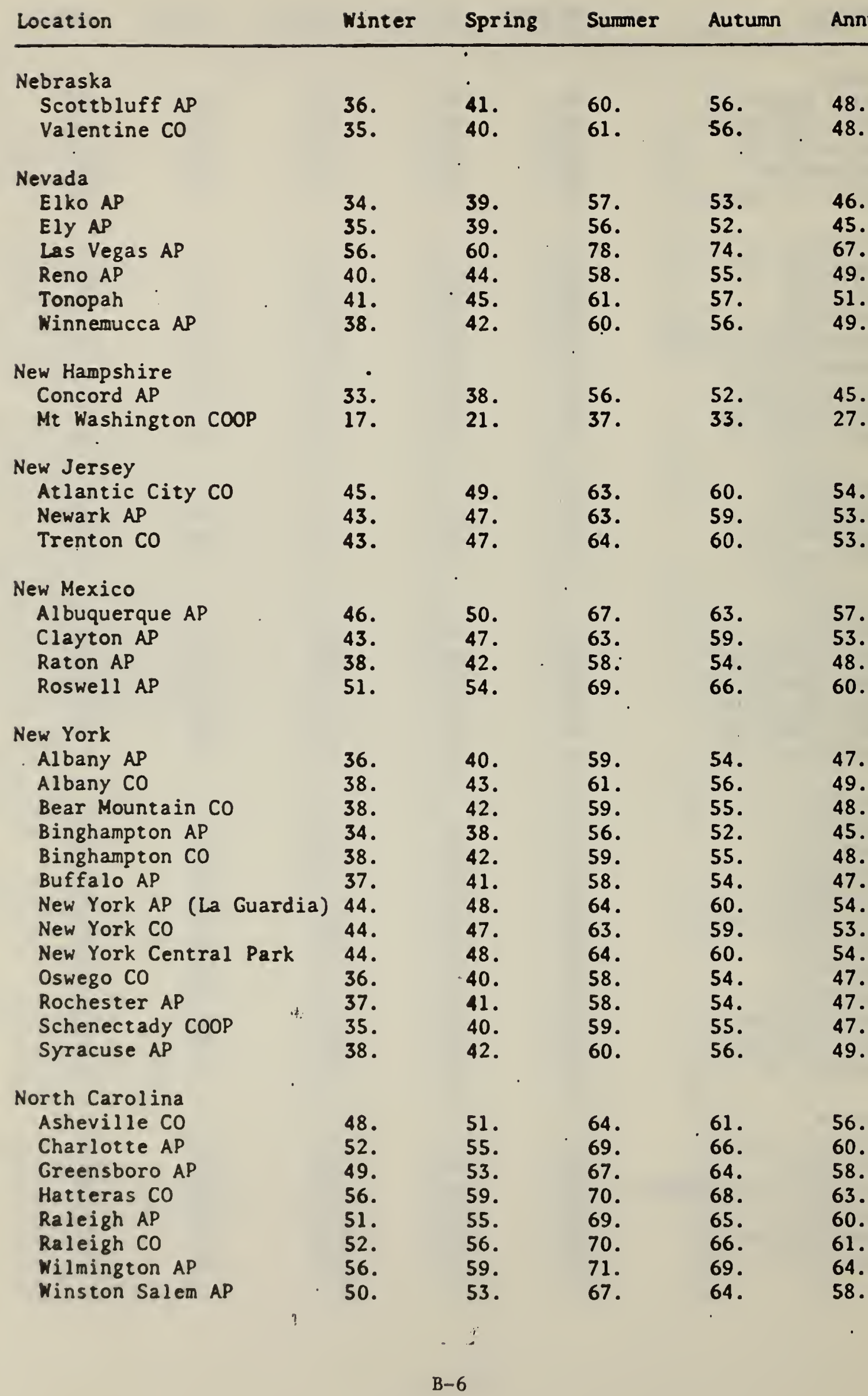


North Dakota

Bismarck AP

Devils Lake CO

Fargo AP

Minot AP

Williston $C O$

Ohio

Akron-Canton AP

Cincinnati AP

Cincinnati CO

Cincinnati ABBE OBS

Cleveland AP

Cleveland $C O$

Columbus AP

Columbus CO

Dayton AP

Sandusky CO

Toledo. AP

Youngstown AP

Oklahona

Oklahoma City AP

Oklahoma City CO

Tulsa AP.

Oregon

Astoria AP

Baker CO

Burns CO

Eugene AP

Meacham AP

Medford AP

Pendelton AP

Portland AP

Portland CO

Roseburg AP

Roseburg $\mathrm{CO}$

Salem AP

Sexton Summit

Troutdale AP

\section{Pennsylvania}

Allentown AP

Erie AP

Erie CO

Harrisburg AP

Park Place CO

Philadelphia AP

Philadelphia CO

Pittsburgh Allegheny
27.

24.

26.

25.

27.

39.

43.

46.

45.

40.

41.

41.

43.

42.

41.

38.

39.

50.

50.

50.

47.

36.

36.

46.

34.

46.

42.

46.

48.

47.

48.

46.

42.

45.

40.

38.

40.

43.

36.

44.

46.

42.
33.

29.

32.

31.

33.

43.

47.

50.

49.

44.

45.

46.

47.

46.

45.

43.

43.

54.

55.

54.

48.

40.

40.

48.

38.

49.

46.

49.

50.

49.

51.

49.

44.

48.

44.

42.

44.

47.

40.

48.

50.

46.
56.

54.

56.

54.

56.

60.

64.

66.

65.

61.

62.

62.

64.

63.

62.

60.

60.

71.

71.

71.

67.

68.

67.

60.

63.

61.

57.

58.

59.

60.

59.

58.

56.

56.

50

54.

56.

55.

51.

51.

52.

53.

52.

51.

49.

50.

60.

61.

61.

56.

56.

58.

59.

52.

62.

63.

60.

61.

60.

61.

60.

55.

59.

54.

52.

54.

57.

49.

59.

59.

57.

59.

57.

59.

57.

52.

57.

51.

46.

47.

52.

43.

54.

53.

53.

55.

53.

55.

53.

48.

52.

62.

58.

60.

63.

57.

64.

66.

62.
58.

55.

56.

59.

53.

61.

62.

58.
51.

48.

50.

53.

46.

54.

56.

52. 


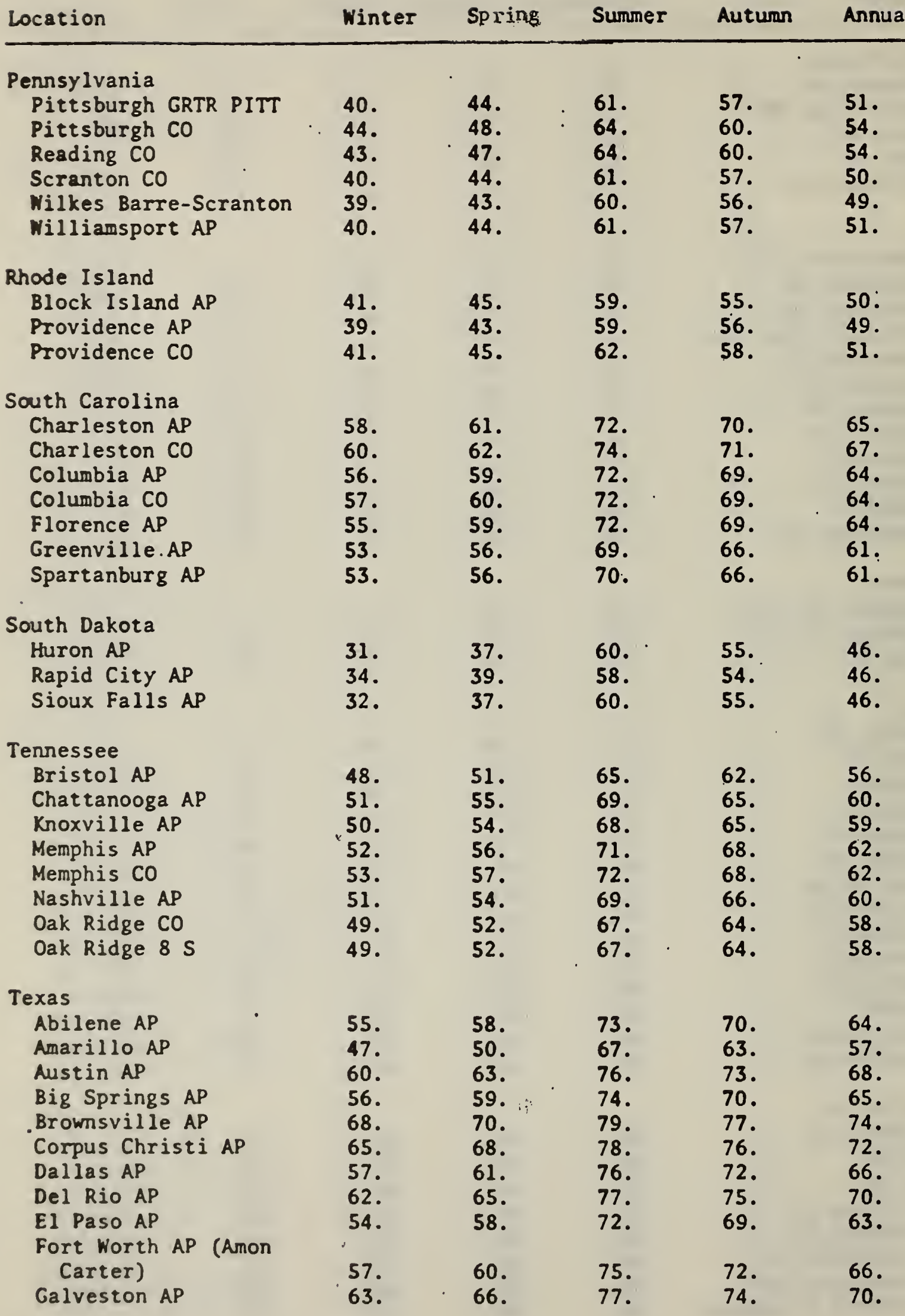


Texas

Galveston CO

Houston AP

Houston CO

Laredo AP

Lubbock AP

Midland AP

Palestine CO

Port Arthur AP

Port Arthur CO

San Angelo AP

San Antonio AP

Victoria AP

Waco AP

Wichita Falls AP

Utah

Blanding $\mathrm{CO}$

Milford AP

Salt Lake City AP

Salt Lake City CO

\section{Vermont}

Burlington AP

\section{Virginia}

Cape Henry CO

Lynchburg AP

Norfolk AP

Norfolk CO

Richmond AP

Richmond CO

Roanoke AP

\section{Washington}

Ellensburg AP

Kelso AP

North Head L H RESVN

Olympia AP

Omak $2 \operatorname{mi~} N$

Port Angeles AP

Seattle AP (Boeing Field)

Seattle CO

Seattle-Tacoma AP

Spokane AP

Stampede Pass

Tacoma $\mathrm{CO}$

Tattosh Island CO

Walla Walla CO

Yakima AP
63.

62.

63.

67.

50.

55.

58.

61.

63.

58.

61 .

64.

58.

53.

39.

37.

40 .

41.

32.

51.

48.

51.

52.

48.

50.

48.

37.

45.

47.

44.

36.

45.

46.

47.

44.

37.

32.

46.

46.

44.

40.
66.

65.

66.

70.

54.

59.

62.

64.

65.

61.

64.

67.

62.

57.

43.

42.

44.

46.

37.

57.

60.
61.
63
65

60.
61.
63.
65.

60.
61.
63.
65.

76.

77.

81.

69.

73.

74.

75.

76.

74.

77.

78.

76.

73.

56.

56.

59.

60.

52.

44.

55.

68.

66.

68.

69.

67.

68.

66.

51.

41.

47.

49 .

46.

40.

46.

48.

50.

47.

41.

35.

48.

47.

48.

44.

59.

57.

54.

56.

59.

53.

65.

60.

62.

57.

64.

59.

66.

61.

63.

58.

64.

59.

62.57.

50.

51.

53.

58.

59.

57.

58.

48.

58 .

52.

65.

55.

48.

54.551 .

53.551 .

54.50.

55.47.

52.49 .

61.

56.

57.

52.

51.

54.47.

45.40 .

55.552.

51.49.

61.54.

57.55. 
West Virginia

Charleston AP

Elkins AP

Huntington $\mathrm{CO}$

Parkersburg CO

Petersburg CO

Wisconsin

Green Bay AP

La Crosse AP

Madison AP

Madison $C O$

Milwaukee AP

Milwaukee CO

Wyoming

Casper AP

Cheyenne AP

Lander AP

Rock Springs AP

Sheridan AP

Hawa $i$

Hilo AP

Honolulu AP

Honolulu CO

Lihue AP

\section{Alaska}

Anchorage AP

Annette AP

Barrow AP

Bethel AP

Cold Bay AP

Cordova AP

Fairbanks AP

Galena AP

Gambell AP

Juneau AP

Juneau $C O$

King Salmon AP

Kotzebue AP

McGrath AP

Nome AP

Northway AP

Saint Paul Island AP

Yakutat AP

West Indies

Ponce Santa Isabel AP 75.

San Juan AP
47.

41.

48.

45 .

44.

31.

32.

34.

34.

35.

36 .

34.

35 .

31.

31.

33.

72.

74.

74.

72.

25.

40 .

4.

18.

33.

32.

14.

13.

15.

34.

36.

25.

10 .

14.

16.

12.

31.

33.

75.
77.
50.

45.

52.

49.

48.

36.

38.

39.

39.

40.

41.

38.

39.

35.

35.

37.

72.

75.

74.

73.

56.

60.

59.

60.

58.

59.

57.

55.

56.

54.

56.

74.

77.

77.

76.

46.

51.

16.

41.

43.

45.

38 .

37.

34.

47.

49.

44.

31 .

37.

37.

32.

40.

45.

36.

76.

77.
78.

79.
61.

56.

63.

61.

60.

56.

50.

57.

55.

54.

51. 44.

$55 . \quad 46$.

54.47.

$55 . \quad 47$.

54.

47.

55 .

48.

52.

45.

51.45 .

51.43 .

50.42.

$52 . \quad 44$.

74.

73.

76.

76.75.

$75 . \quad 74$.

35.

46.

$\begin{array}{ll}14 . & \\ 37 . & 30 .\end{array}$

$41 . \quad 38$.

$43 . \quad 39$.

34.26.

33.25 .

30.24.

45.41.

46.42.

40.34.

27.21.

33.25.

33.26.

29.22.

$38 . \quad 35$.

$43 . \quad 39$.

$i$

78.

77.

79.

78 . 


\begin{tabular}{|c|c|c|c|c|c|}
\hline Location & Winter & Spring & Surumer & Autumn & Annual \\
\hline $\begin{array}{l}\text { West Indies } \\
\text { San Juan Co } \\
\text { Swan Island }\end{array}$ & $\begin{array}{l}77 . \\
80 .\end{array}$ & $\begin{array}{l}77 . \\
80 .\end{array}$ & $\begin{array}{l}79 . \\
82 .\end{array}$ & $\begin{array}{l}79 . \\
81\end{array}$ & $\begin{array}{l}78 . \\
81\end{array}$ \\
\hline $\begin{array}{l}\text { Virgin Islands } \\
\text { St Croix, V.I. AP }\end{array}$ & 78. & 78. & 81. & $\begin{array}{l}80 . \\
.\end{array}$ & 79. \\
\hline $\begin{array}{l}\text { Pacific Islands } \\
\text { Canton Island AP } \\
\text { Koror } \\
\text { Ponape Island AP } \\
\text { Truk Moen Is land } \\
\text { Wake Island AP } \\
\text { Yap }\end{array}$ & $\begin{array}{l}83 . \\
81 . \\
81 . \\
81 . \\
79 . \\
81 .\end{array}$ & $\begin{array}{l}84 . \\
81 . \\
81 . \\
81 . \\
79 . \\
81 .\end{array}$ & $\begin{array}{l}84 . \\
81 . \\
81 . \\
81 . \\
81 . \\
82 .\end{array}$ & $\begin{array}{l}84 . \\
81 . \\
81 . \\
81 . \\
81 . \\
82 .\end{array}$ & $\begin{array}{l}84 . \\
81 . \\
81 . \\
81 . \\
80 . \\
82 .\end{array}$ \\
\hline \multicolumn{6}{|c|}{$\begin{array}{l}{ }^{a} A P=\text { Airport data. } \\
{ }^{b} C O=\text { City office data. } \\
{ }^{c} \text { COOP = Cooperative weather station. } \\
{ }^{d_{O B S}}=\text { Observation station. }\end{array}$} \\
\hline
\end{tabular}



Append1x C

Fortran Listing of the Computer Program 
MAIN

HCLD

SOLDAT

ZD

F

SAT

ATTIC

CRAWL

GF

SLABR

GAMMAR

BSMT

QECHG

QG

INFIL

QI

DBRH

PVSF

QR

HLHG

THTCX

HCRT

SEU

EREQ

HWHREQ
Main program

C-1

Heating and cooling load determination

$\mathrm{C}-3$

Solar radiation data (Liu-Jordan)

C-15

A subroutine of SOLDAT

C-18

Slab-on-grade perimeter heat loss (unused)

C-19

Sol-air temperature

C-20

Attic air temperature

$C-21$

Crawl space air temperature

C-22

Ground floor heat loss

C-23

Slab-on-grade thermal resistance

C-24

A subroutine of SLABR

C-26

Basement temperature

C-27

Opaque envelope (wall, roof) heat transfer

C-28

Window heat gain

C-29

Infiltration rate

C-30

Infiltration heat gain

C-31

A psychrometric routine

C-32

A psychrometric routine

C-33

Internal heat gain

C-34

Building heat loss and heat gain

C-35

Thermal time constant

C-38

Heating and cooling requirement

C-39

Solar energy utilization

C-40

Energy requirement

C-41

Hot water heating requirement 
Subroutine

Name

CSDUPI

ASDUPI

BMDUPI

OSDUPI

ZKDN

PSY2

WBF

DEGDAY

LINT

MAX

MIN
Subroutine

Description
Page

C-44

C-45

C-46

C-47

C-48

C-49

A psychrometric routine $\quad$ C-40

Energy analysis by the degree day method C-51

Linear interpolation subroutine C-52

Maximum value $\quad$ C-53

$\begin{array}{ll}\text { Minimum value } & C-54\end{array}$

Sample run

C-55 

舅
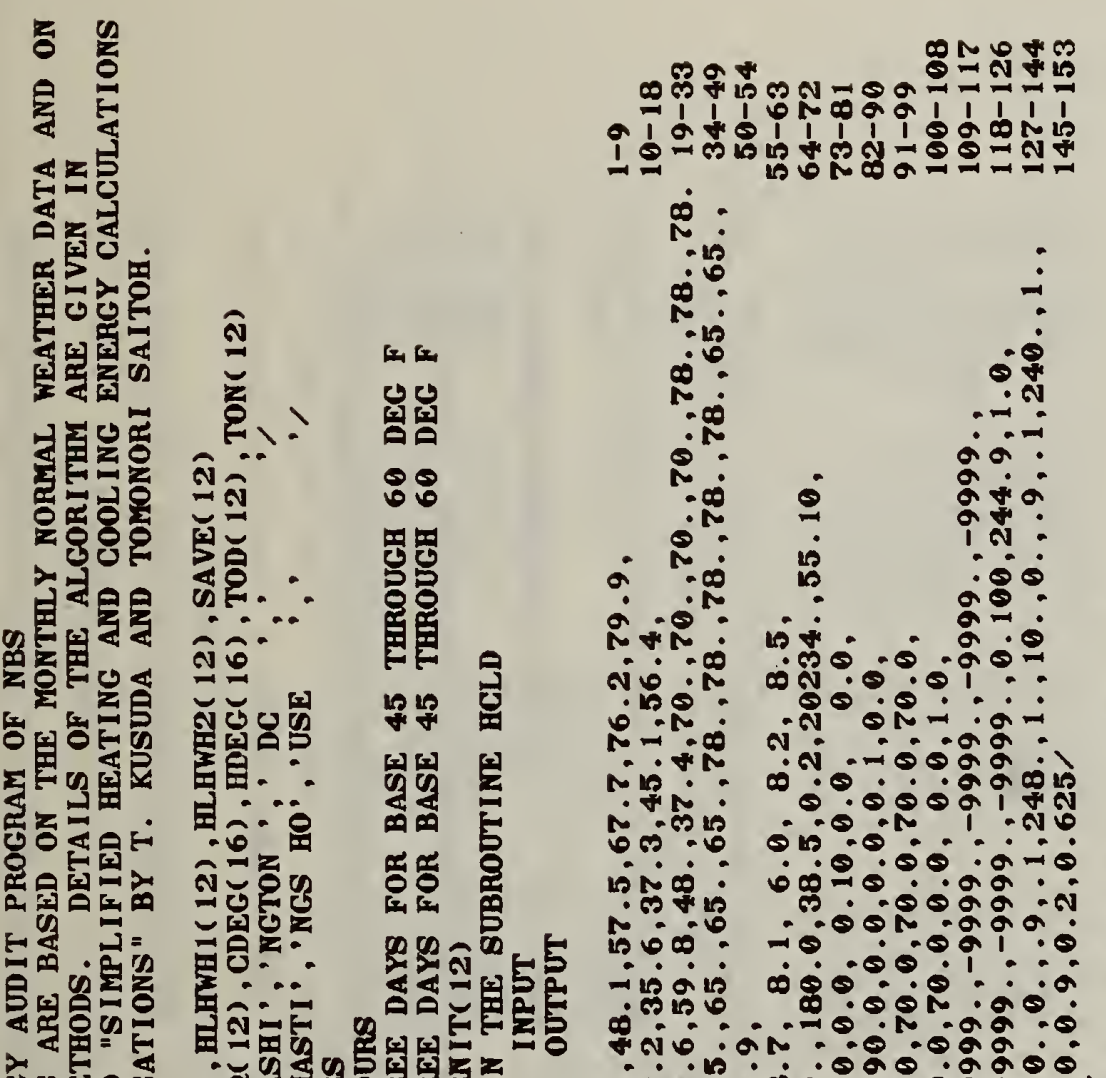

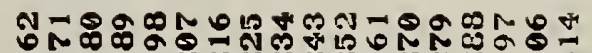

-

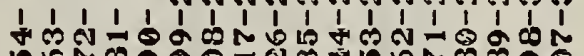

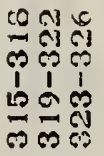

$\dot{0}$

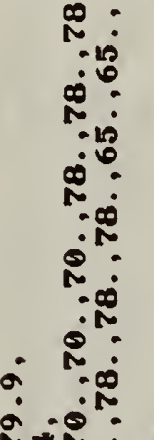

ก-

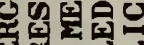

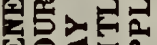

의의

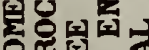

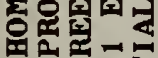

능옹을

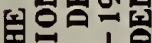

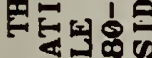

กิด

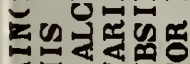

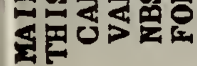

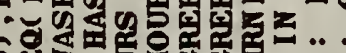
6.

10

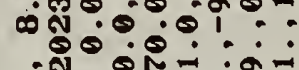

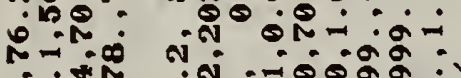

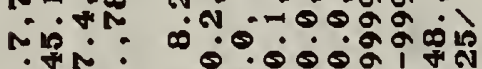

ก. म

का

01000.000

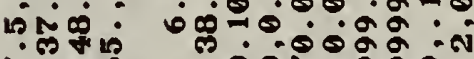

ก.

$-00 \pi 0200$.

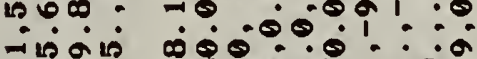

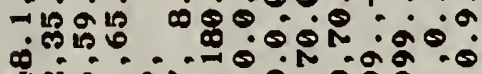

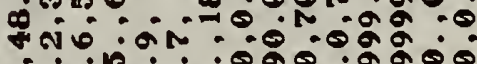

0000000000000000 น - J ใิ

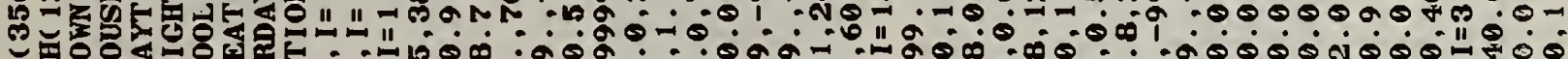

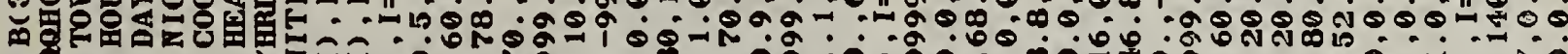
z $\quad$ Z Z

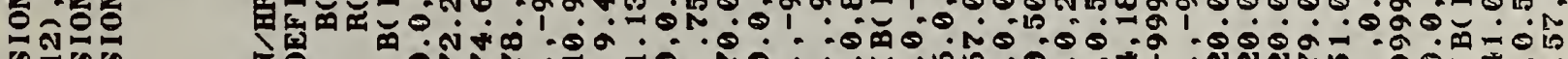
nJy

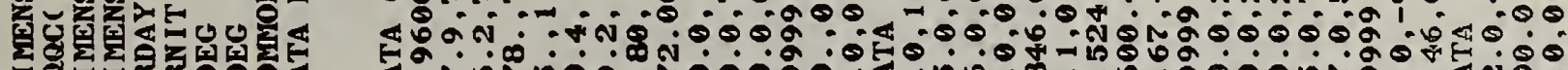

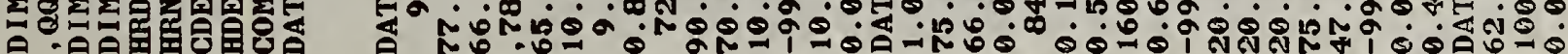

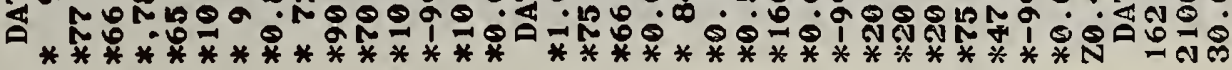

0000000

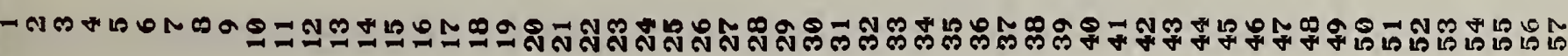


잃
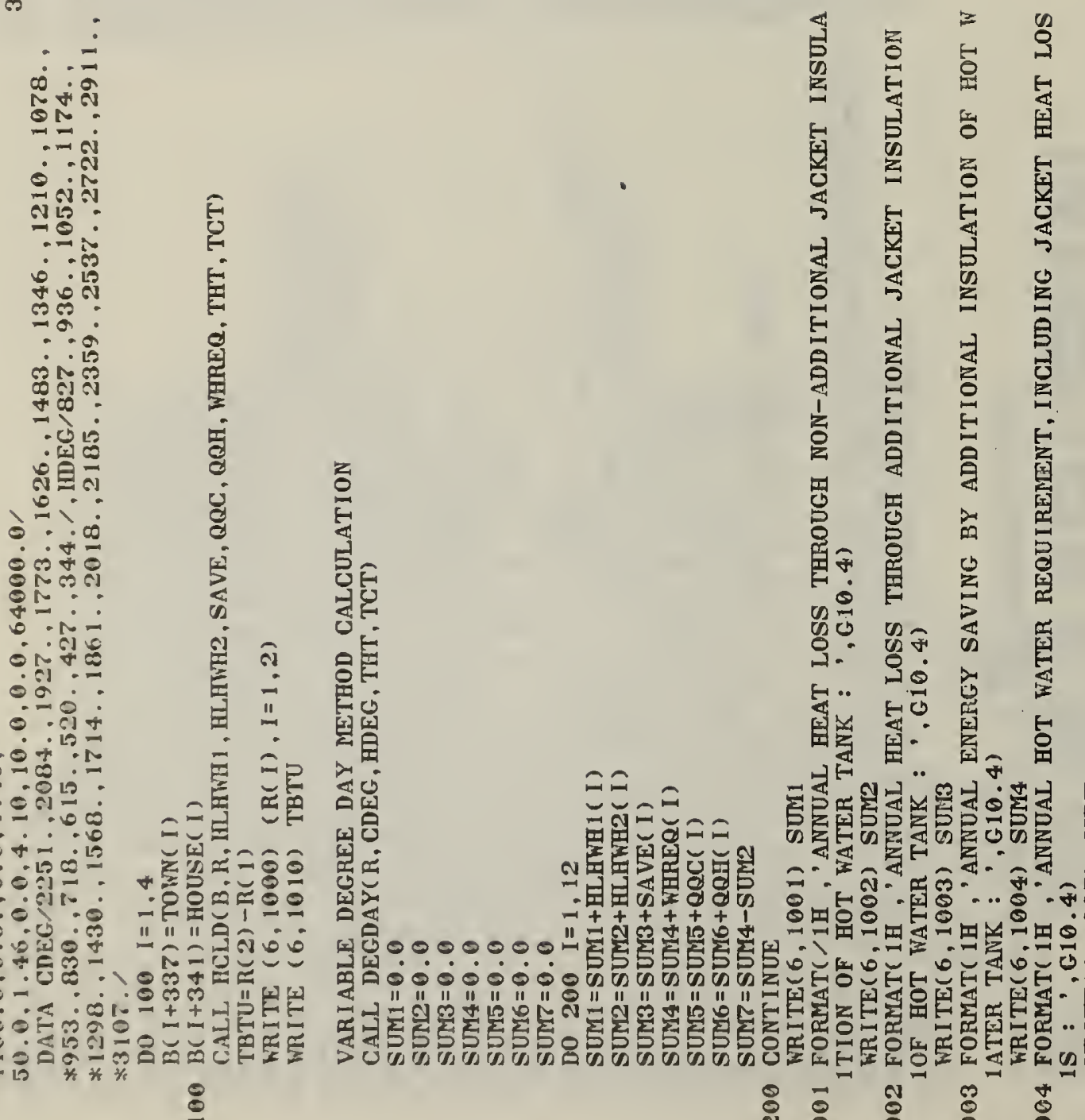

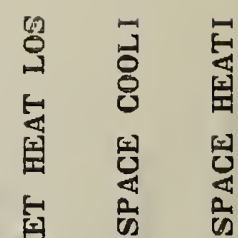

苗 葛

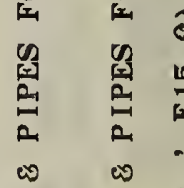

$\infty$

点

点

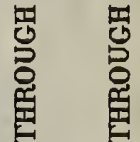

0
0
10
0
0
0
0

(2)

is

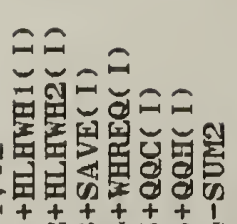

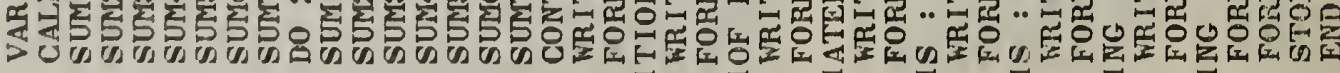

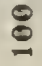

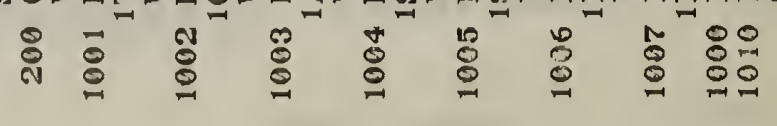



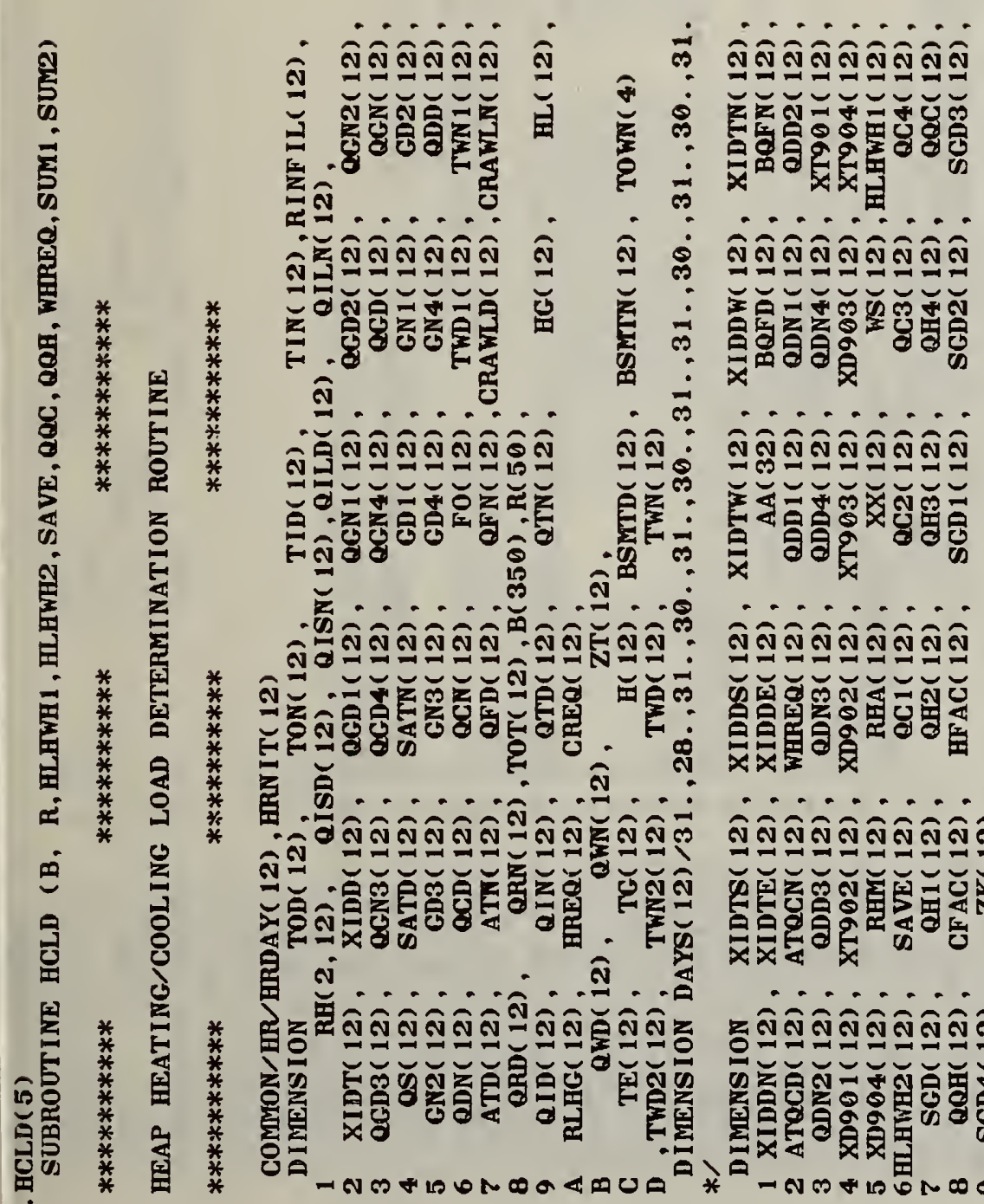

政

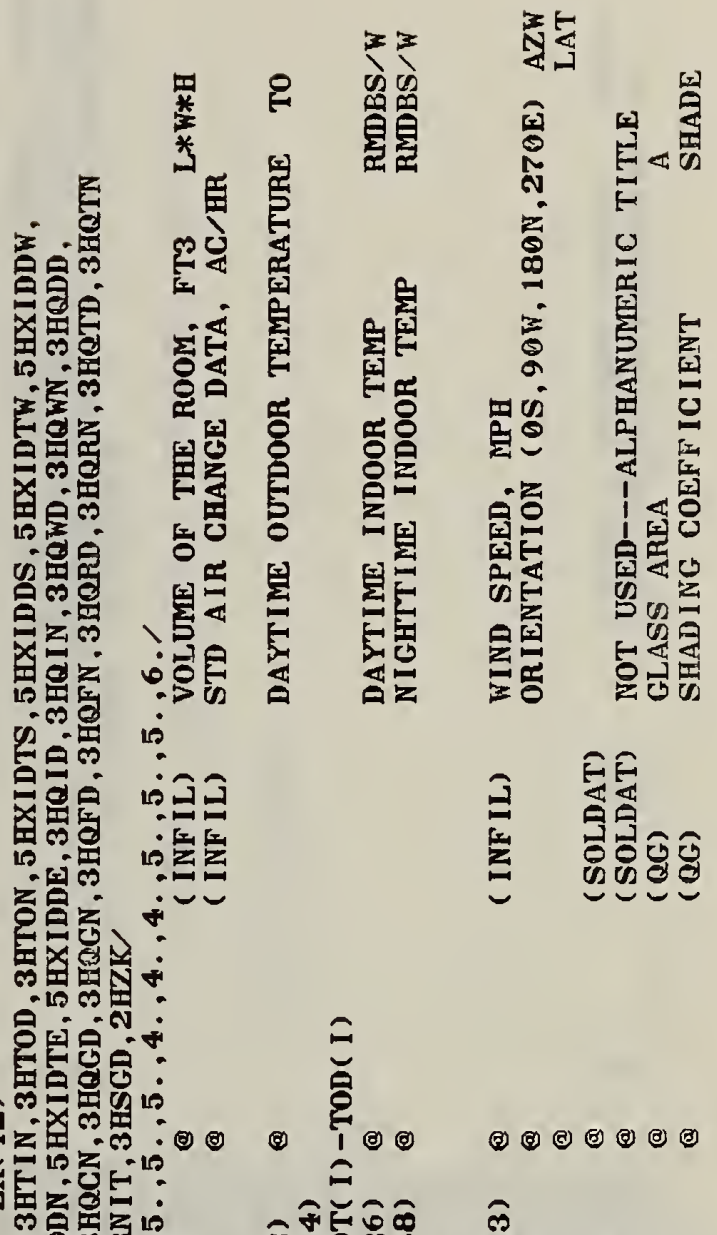

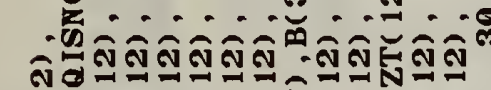

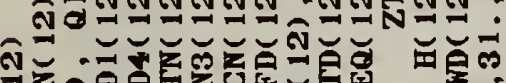

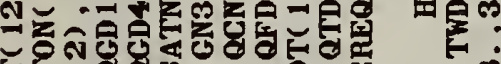

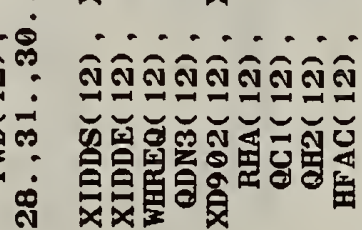
รัด ลิ ก

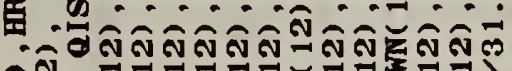

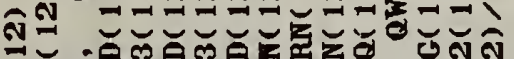

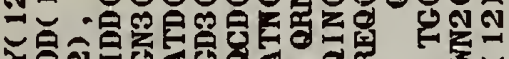

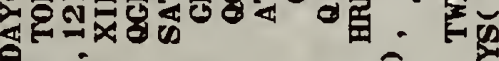

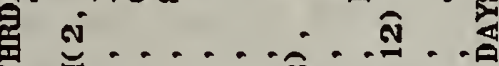
ย้ว

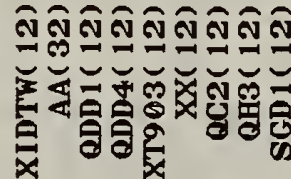
...........

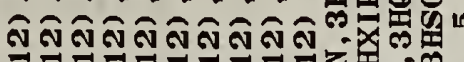

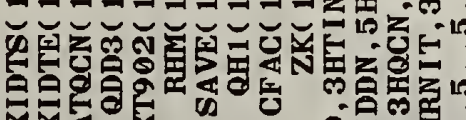

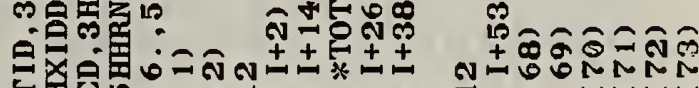

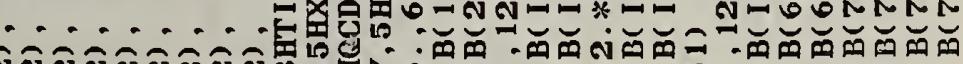

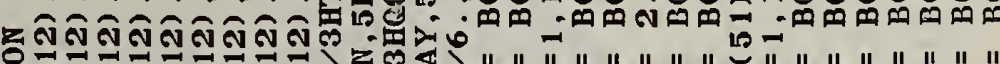

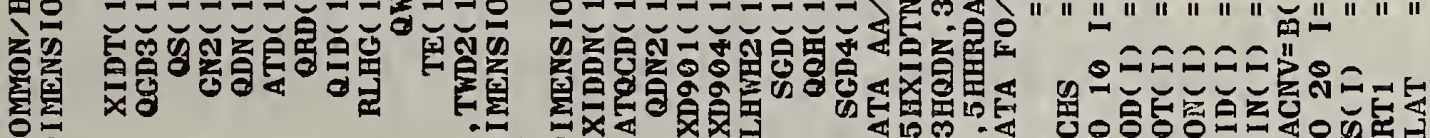
百 ${ }^{a}$ 
D
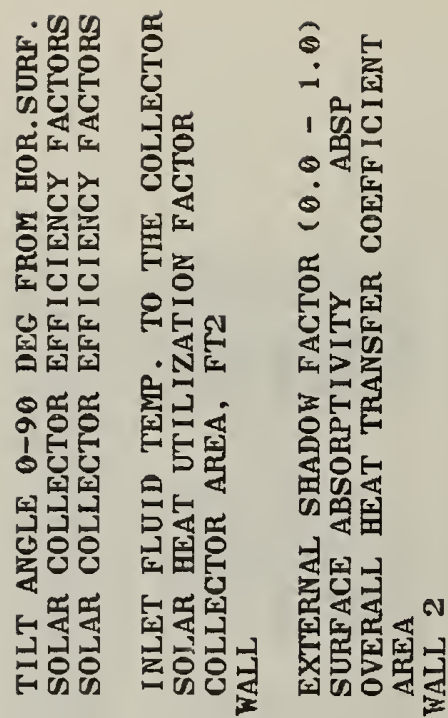

호읠

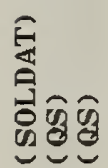<smiles>[Li][As]=[As]=[Ca]</smiles>

等s.

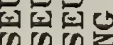

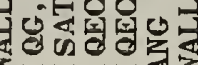

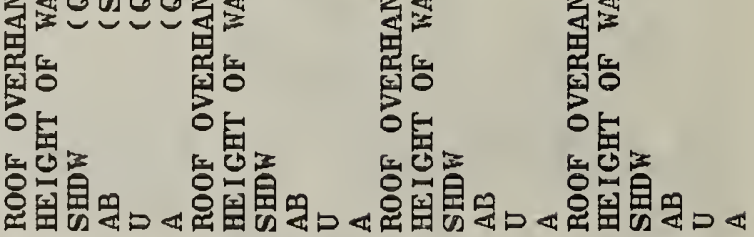

(6)

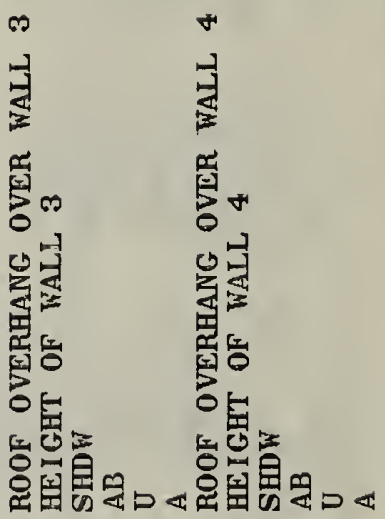

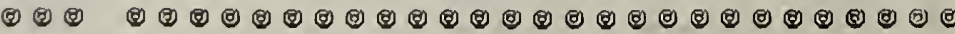

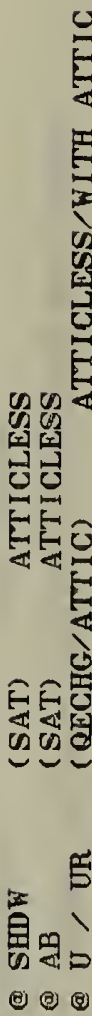

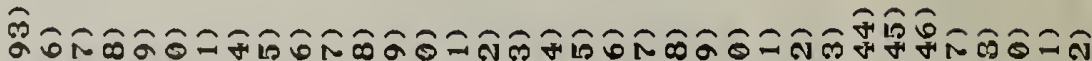

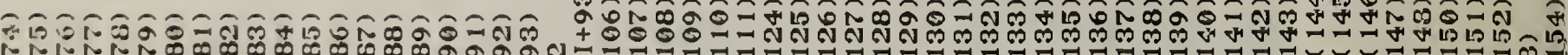

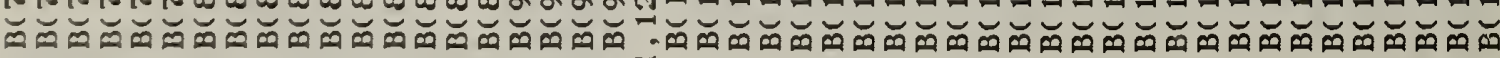

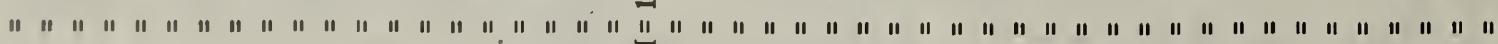
๑ோ

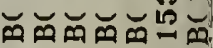

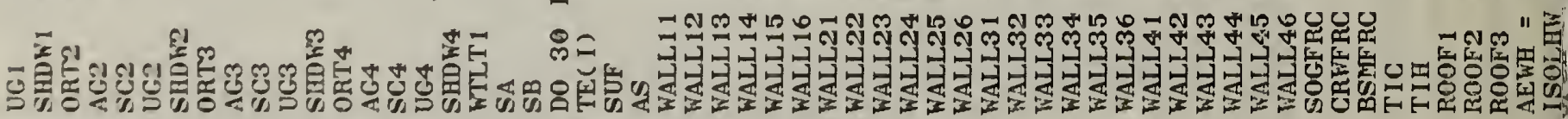

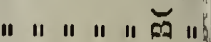
\%

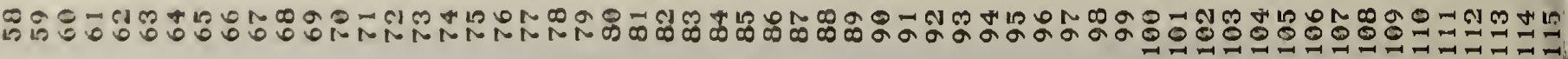




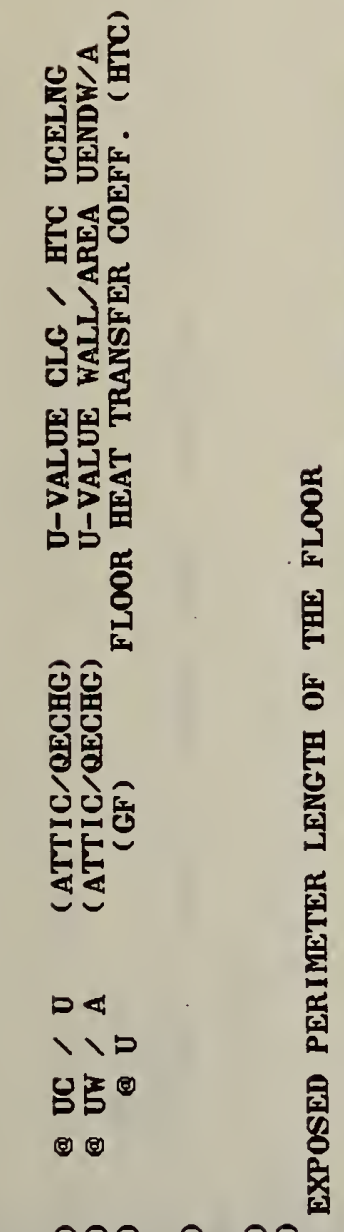

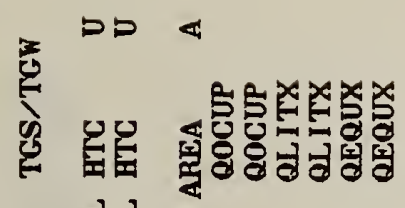

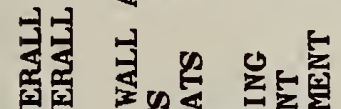

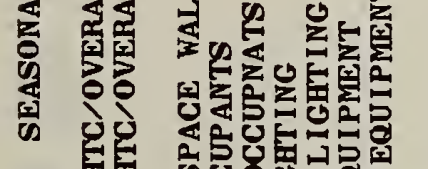

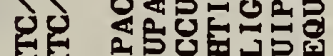

호

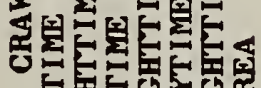

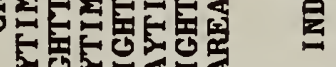

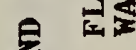

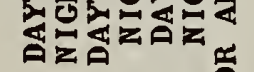

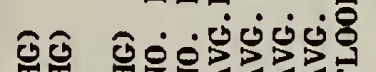

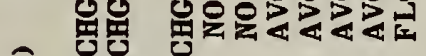

웡

害

过过

金

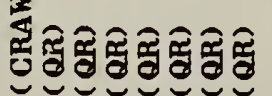

空

采

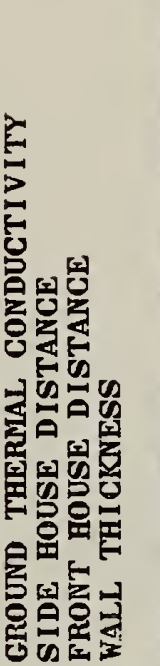

㿣

닌

苍

菑

द्ध

ह

峕

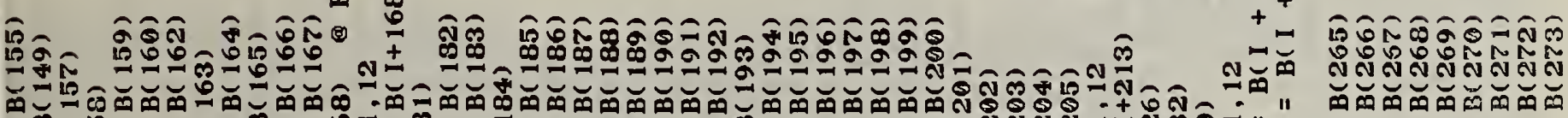

$$
\begin{aligned}
& 00< \\
& 11 \\
& 554
\end{aligned}
$$

总㽣

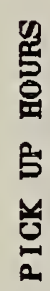

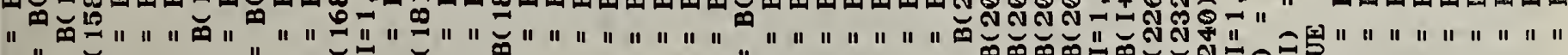

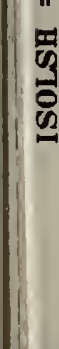

"

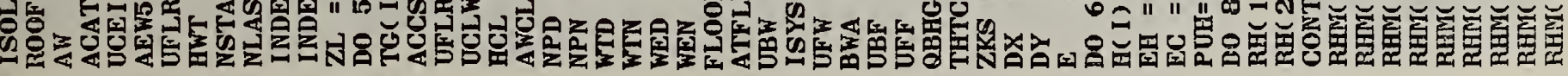

온

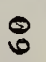

$\$$ 


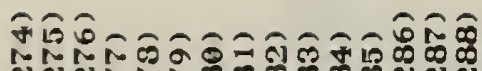

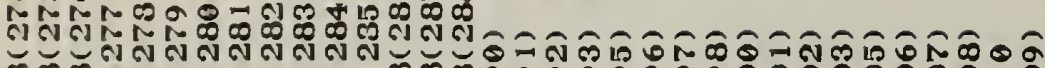
12.7.

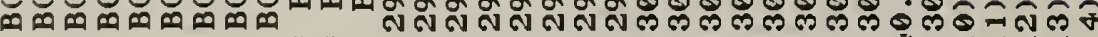

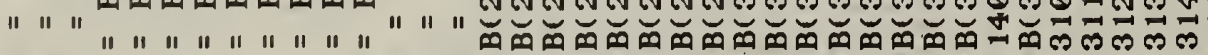

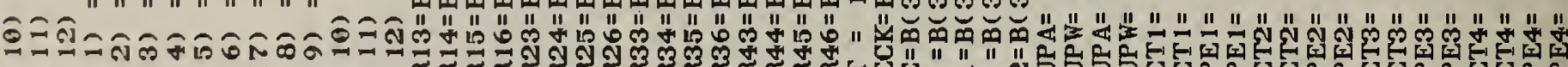

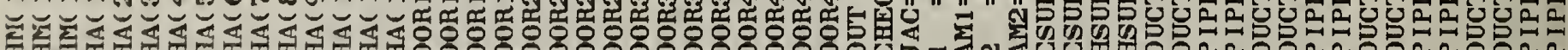

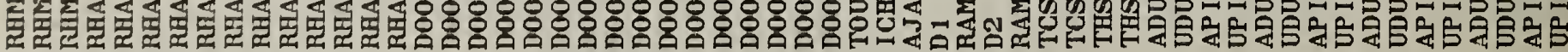

"1 10.1-

C $\underline{6}$ 


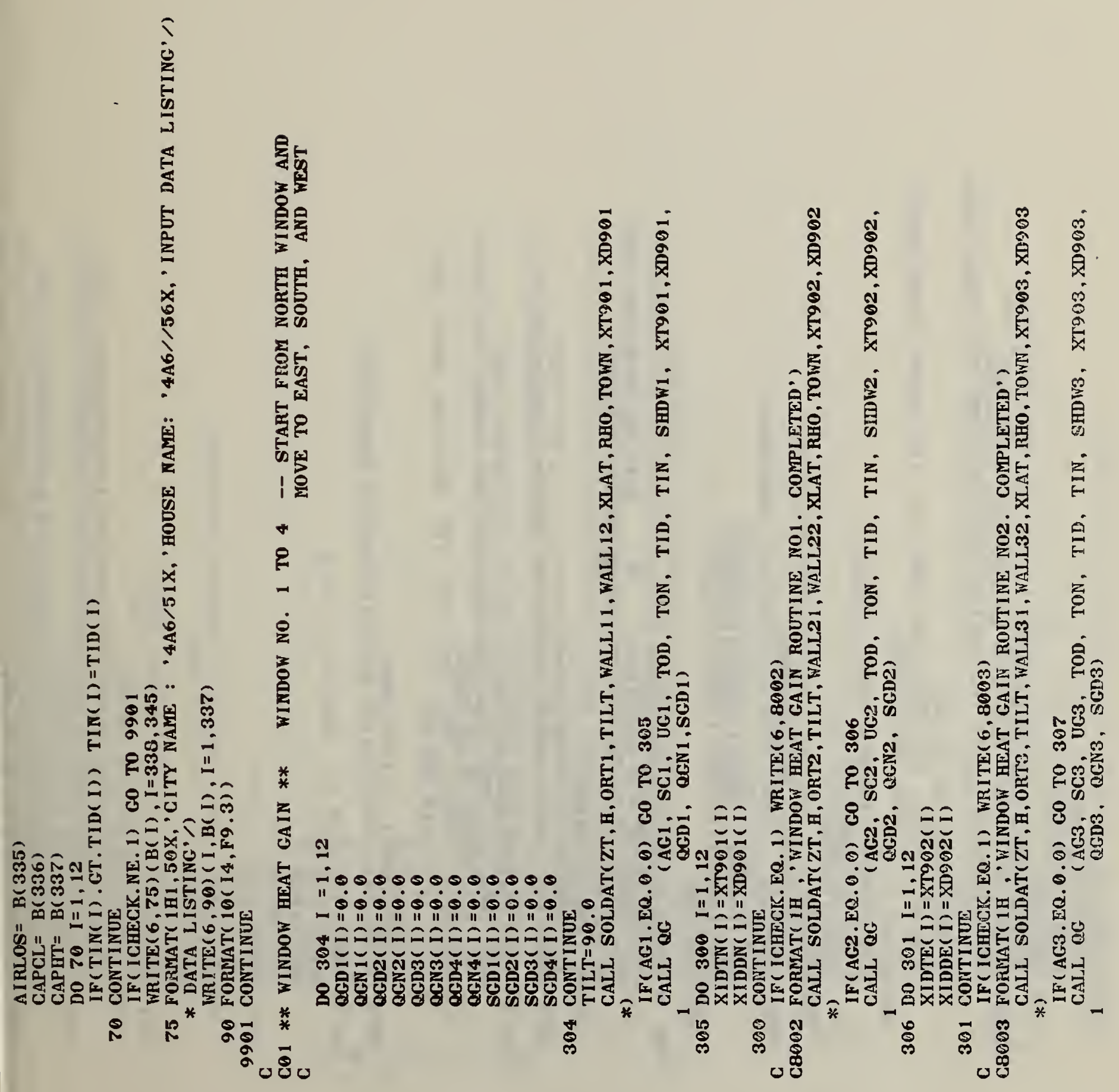

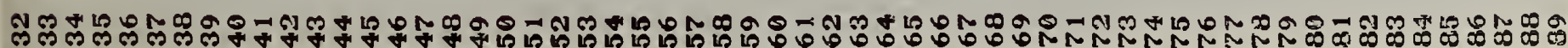
为ส 


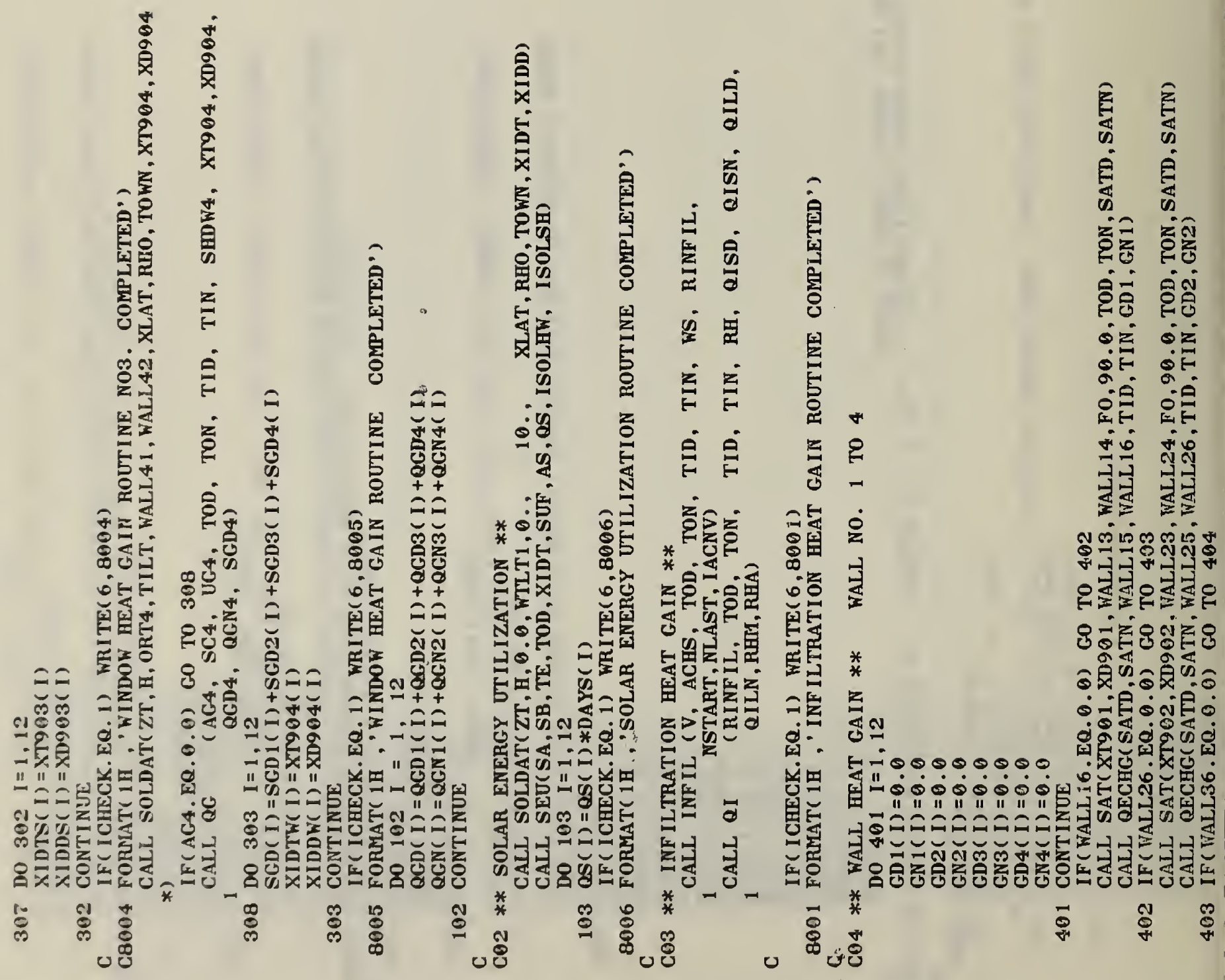

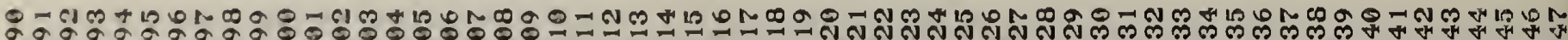

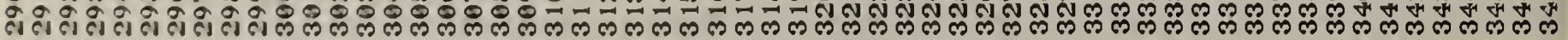




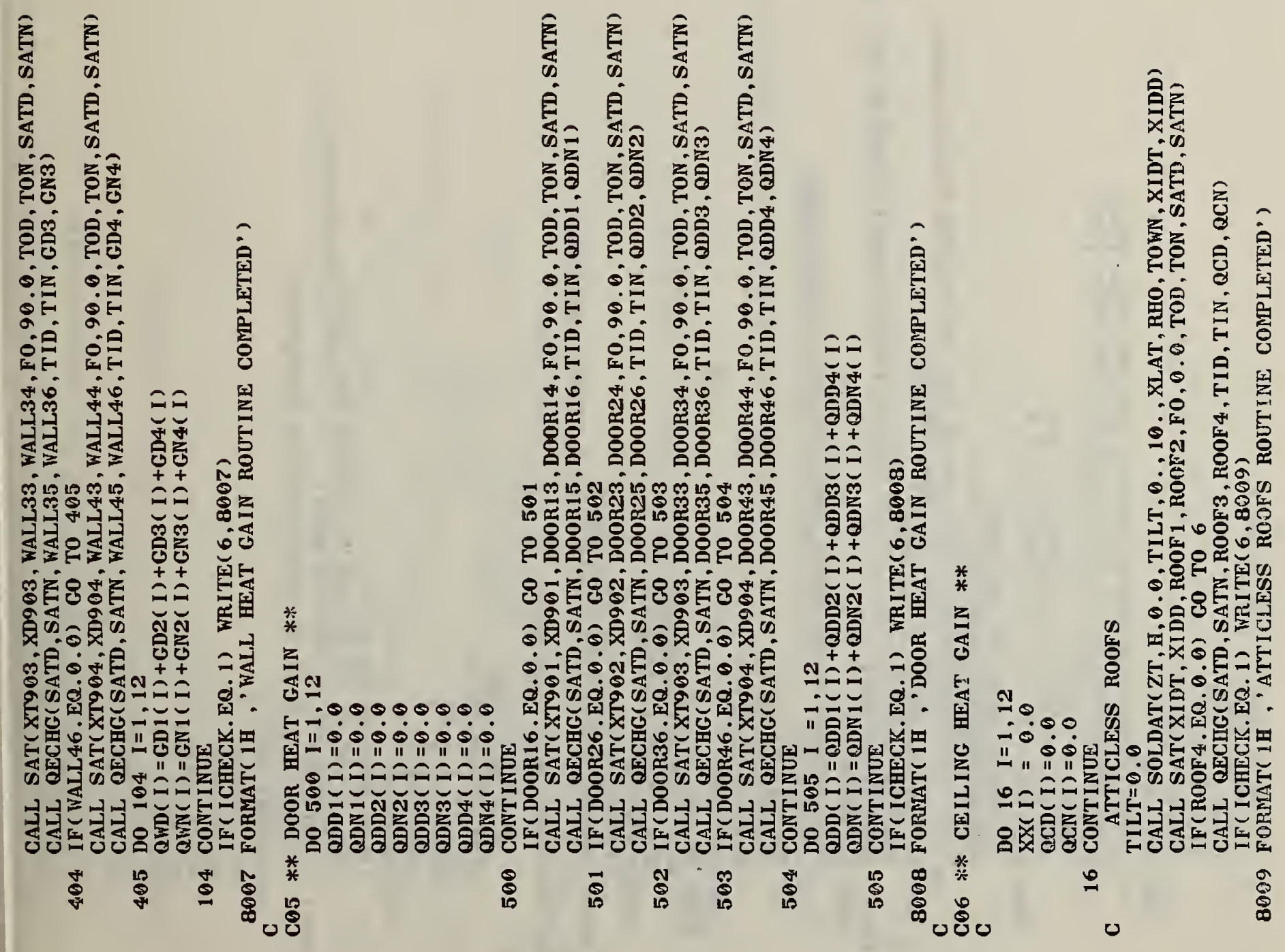

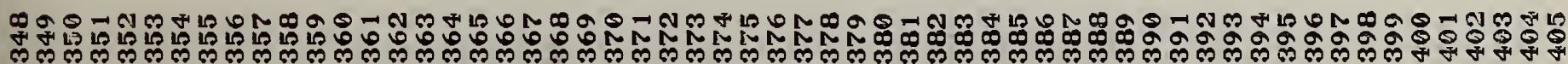




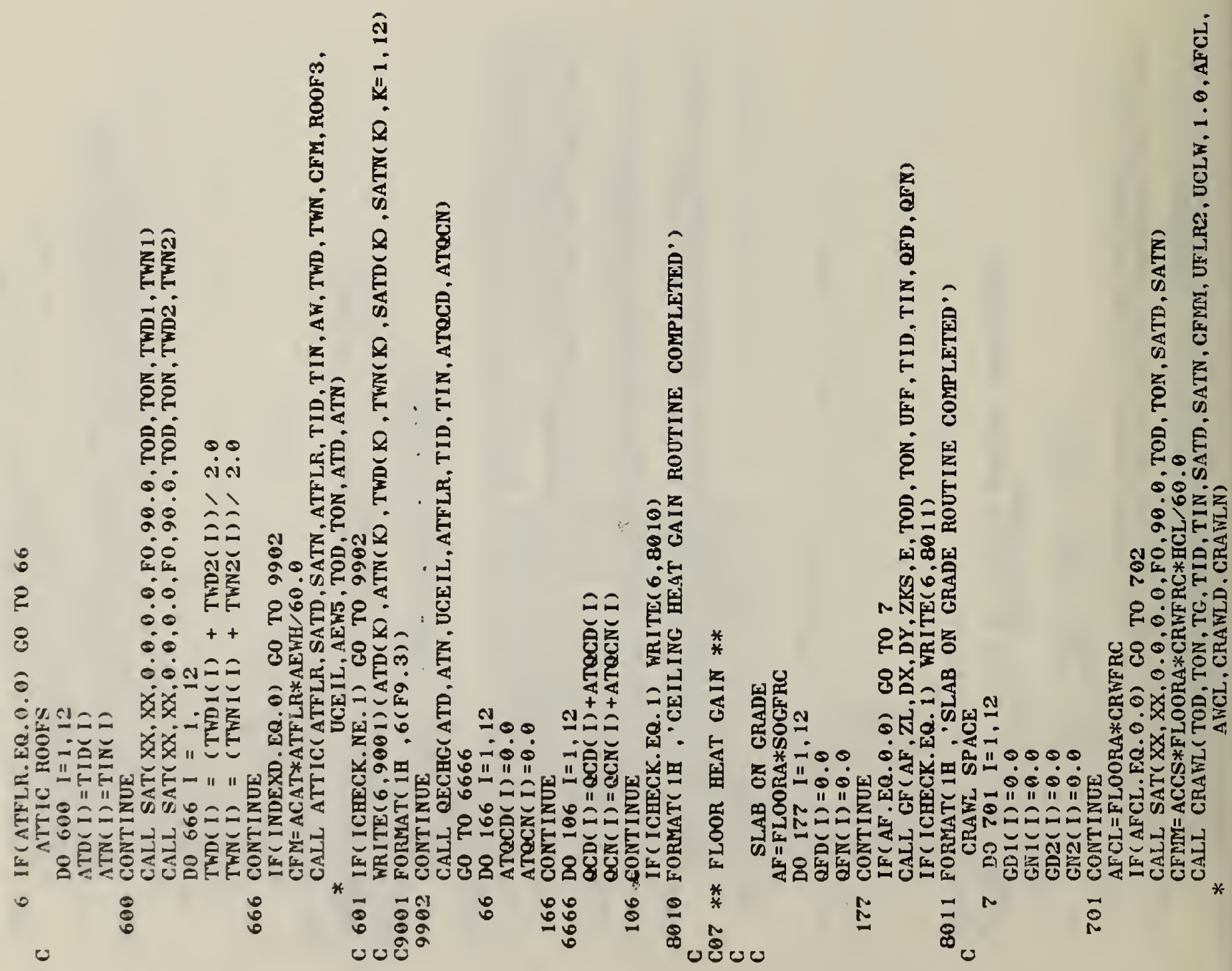

01. D0 -

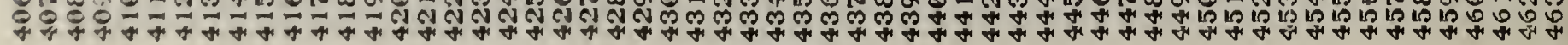




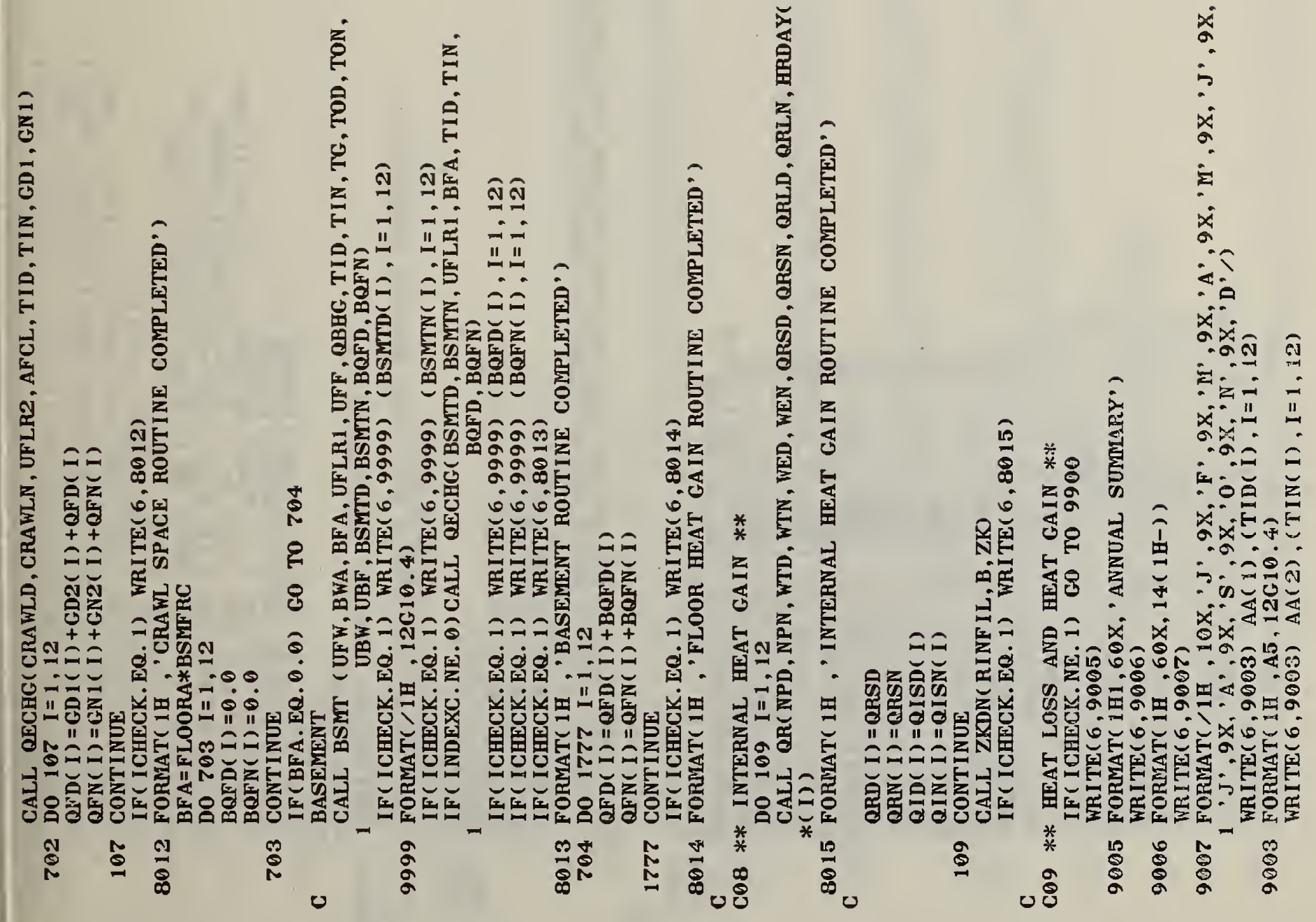

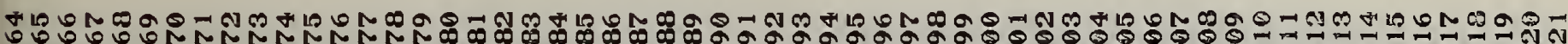

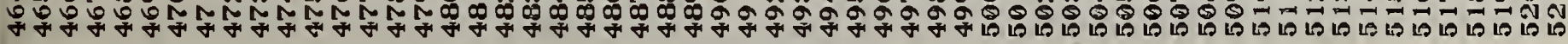




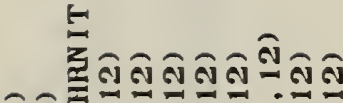

ลิลิำ

"1

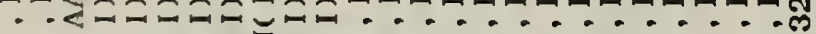
ニニンั幺

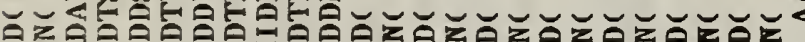

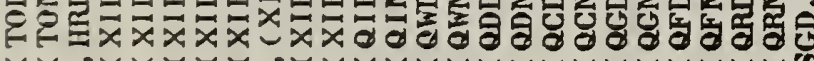
$\because$ ?...

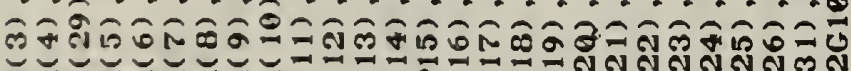

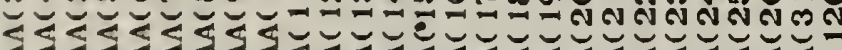

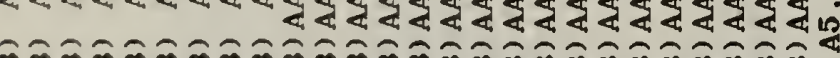
ติ \$.

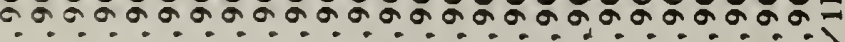

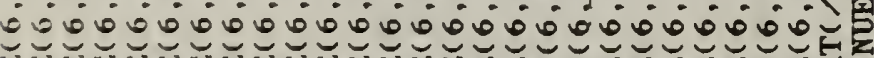

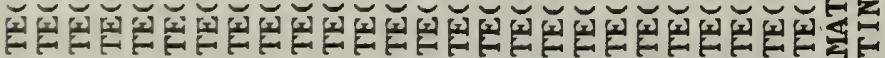

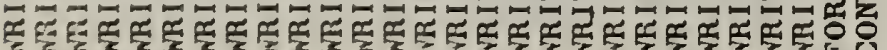

象

ชู่

运完

is

을

送

它

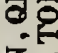

运

पुछ

它

a

zo

桨

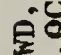

\%

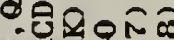
\%

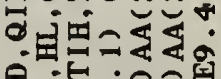

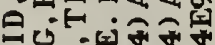

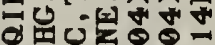

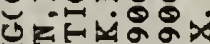

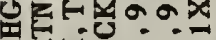

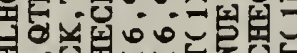

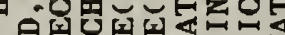

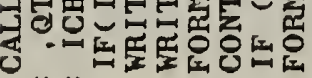
**

6ร)

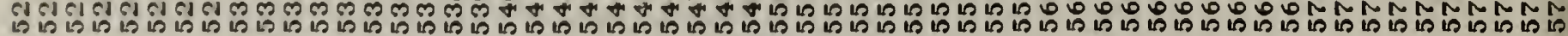



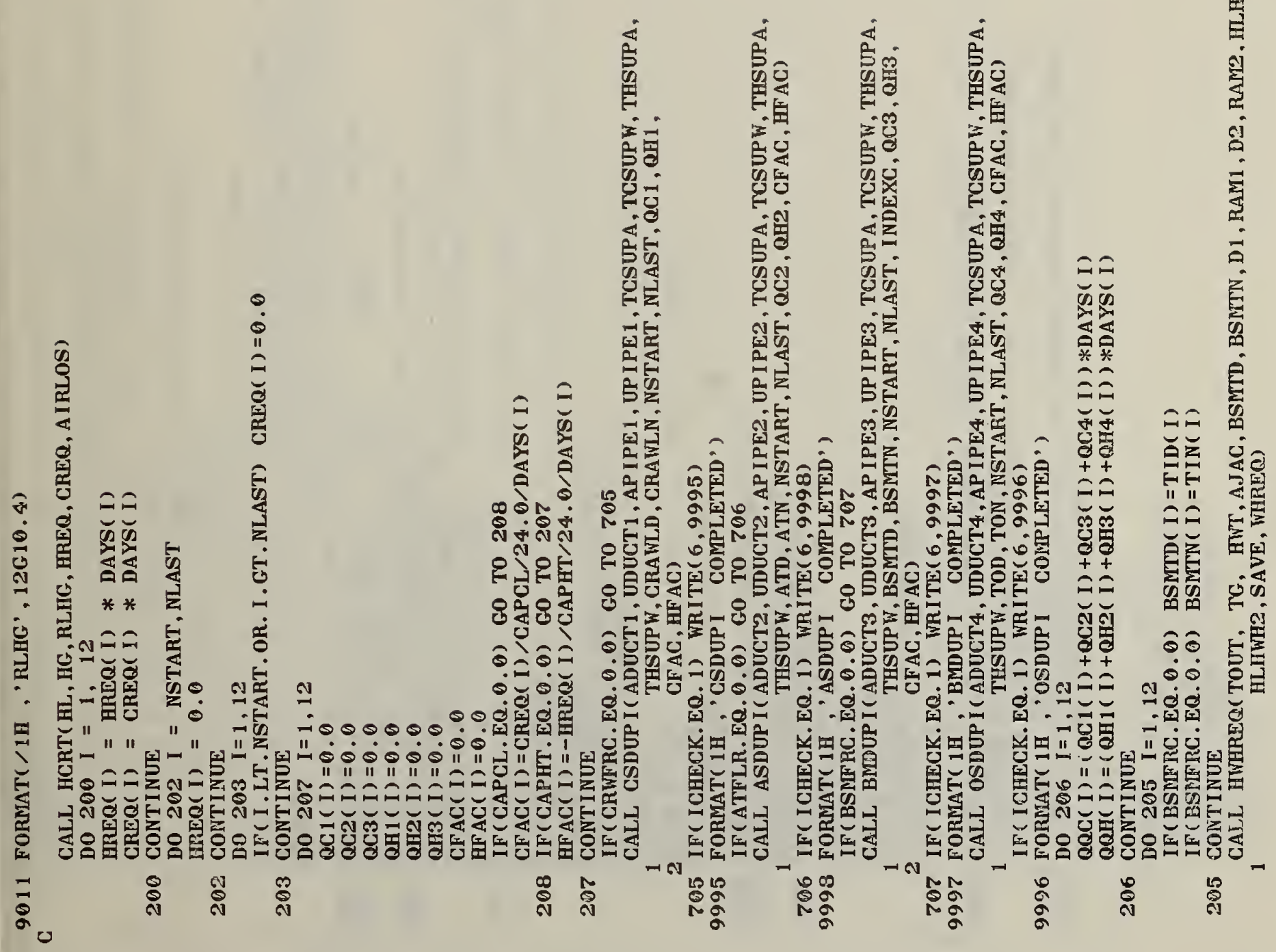

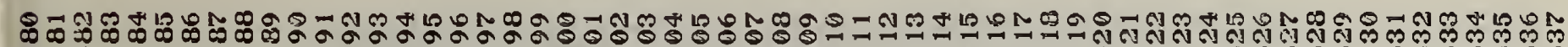
๓ัต 


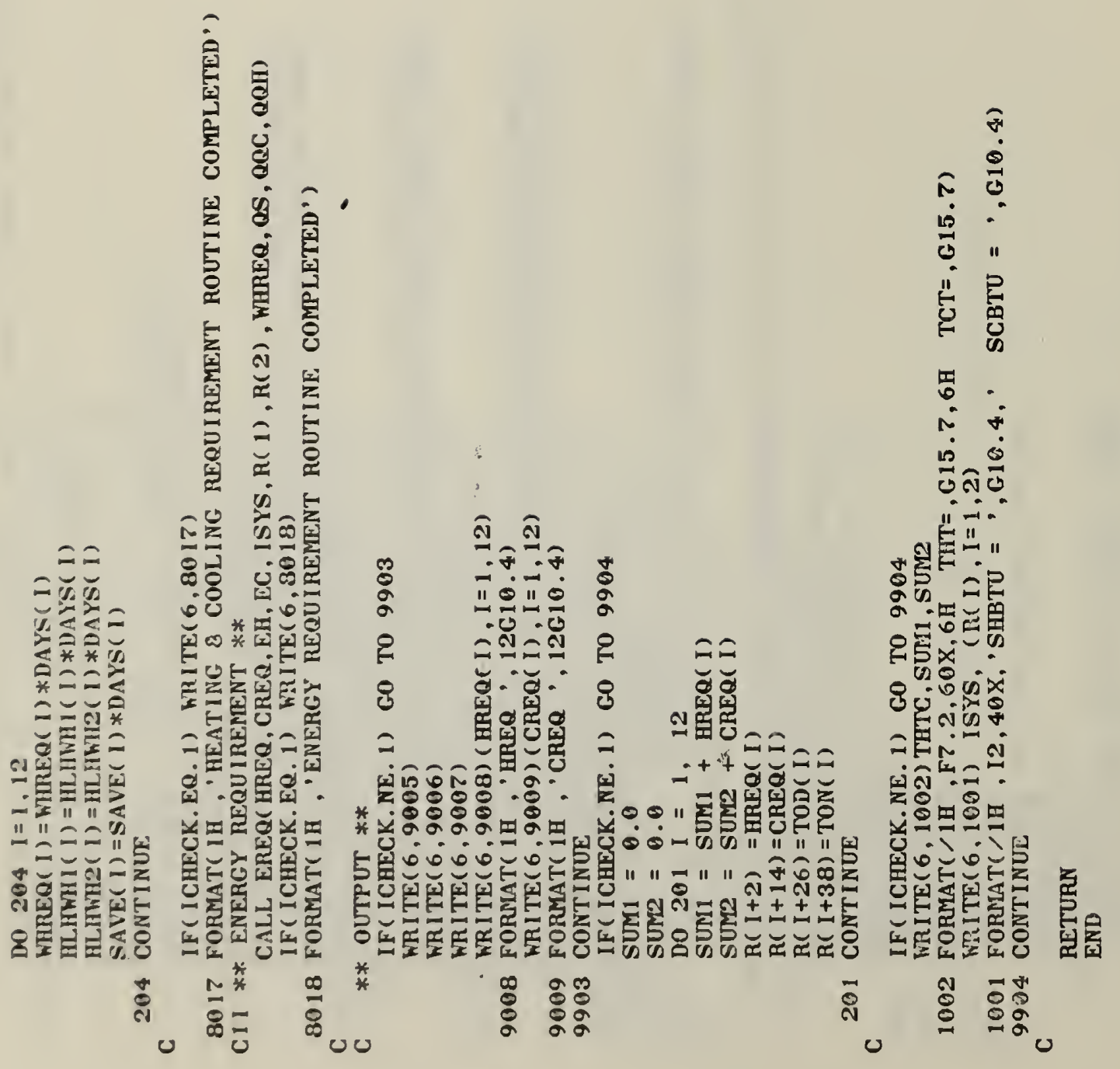

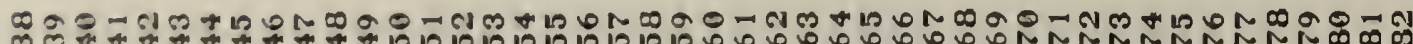

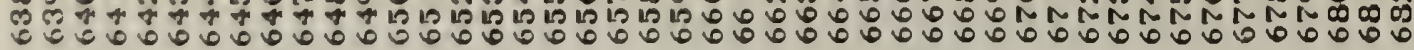



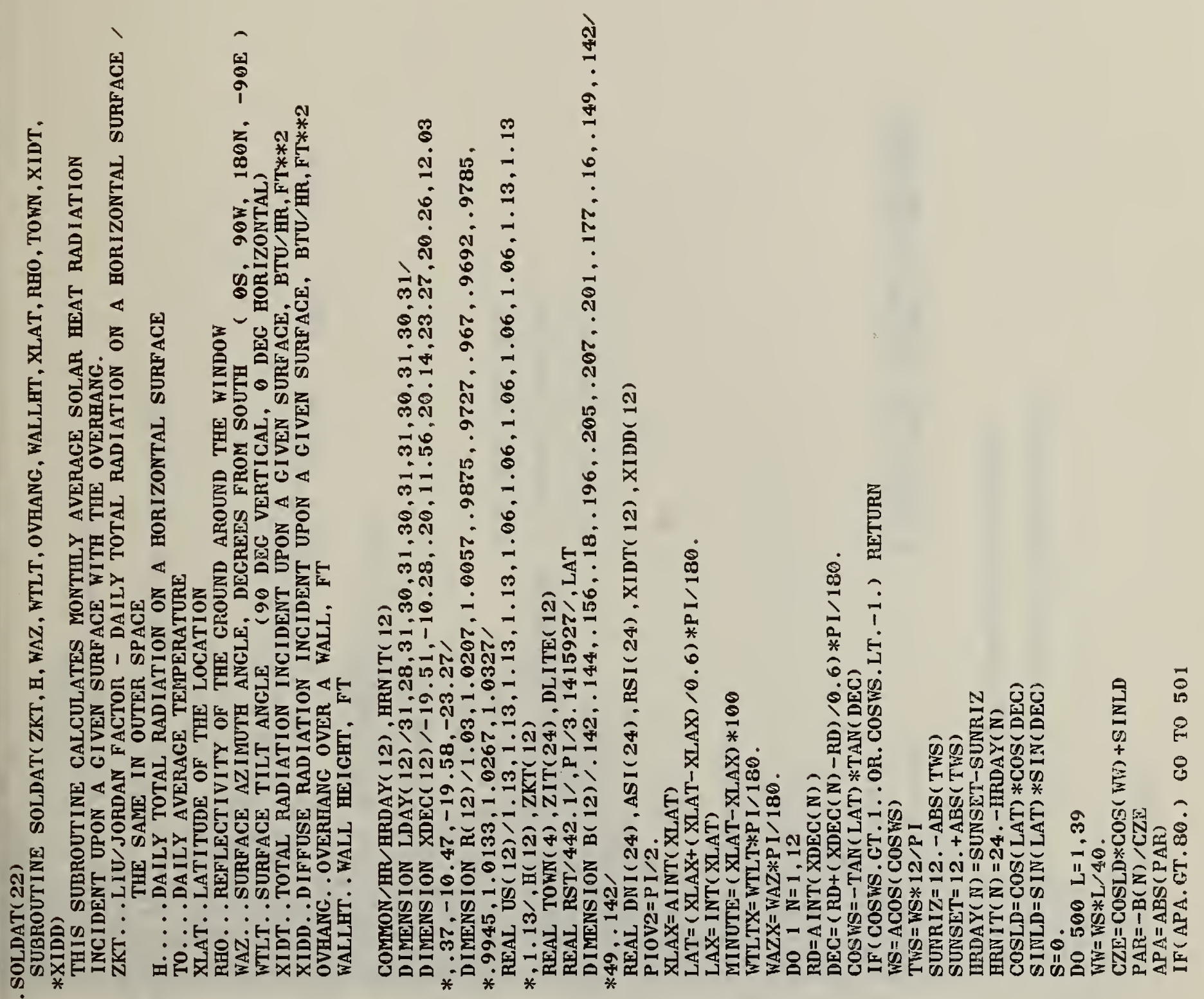

000000000000000

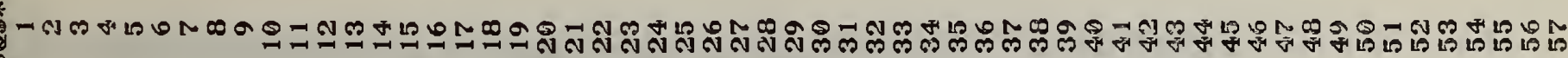




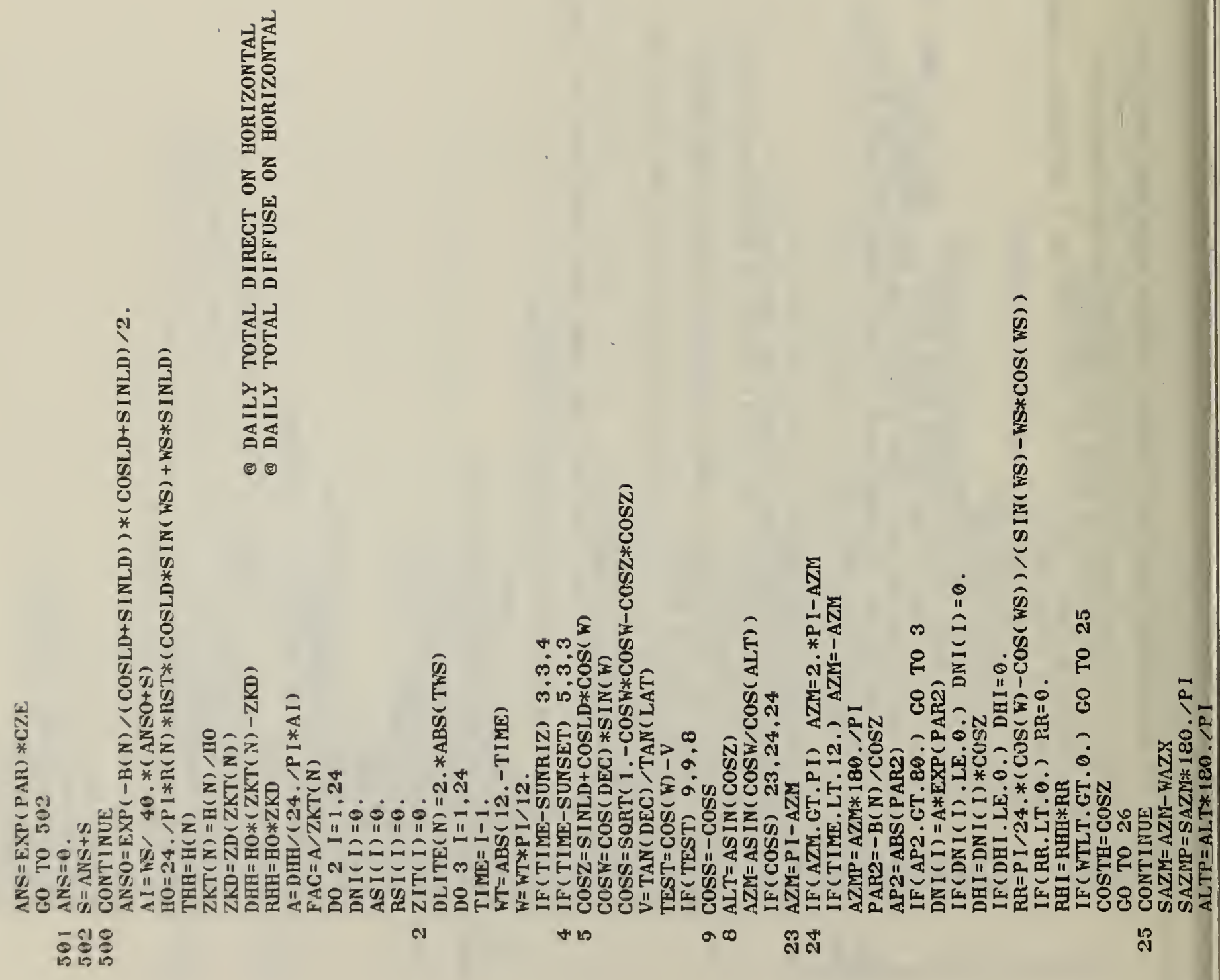

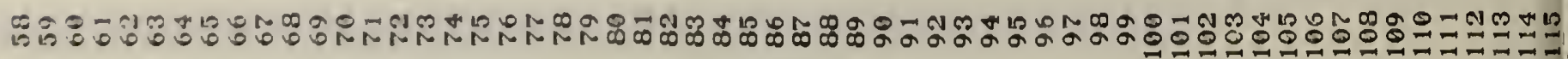

C 16 


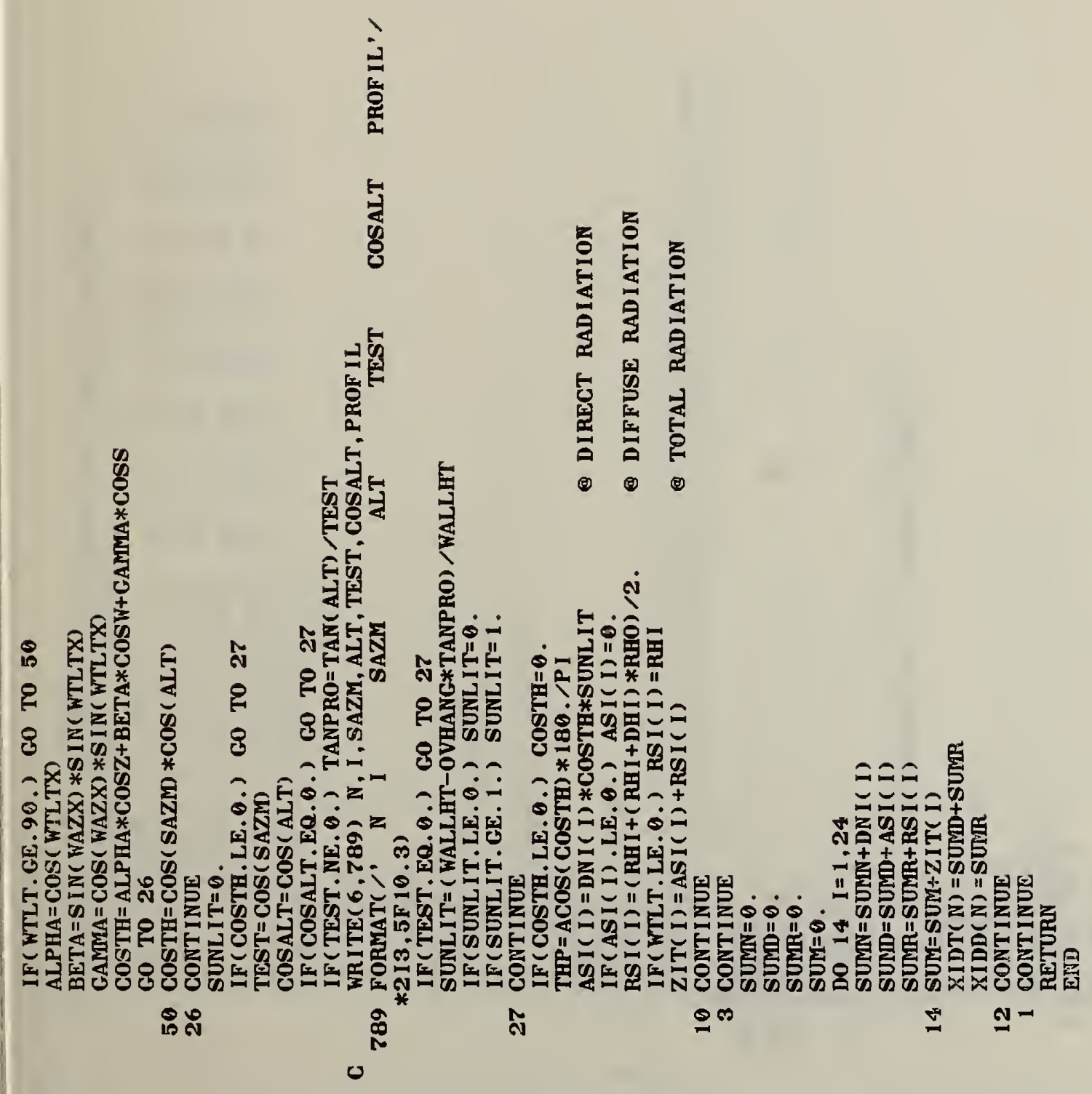

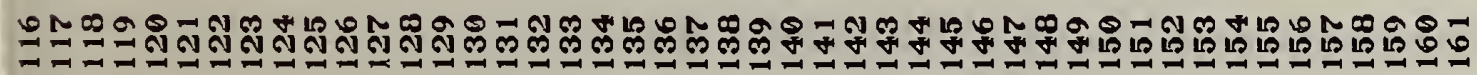




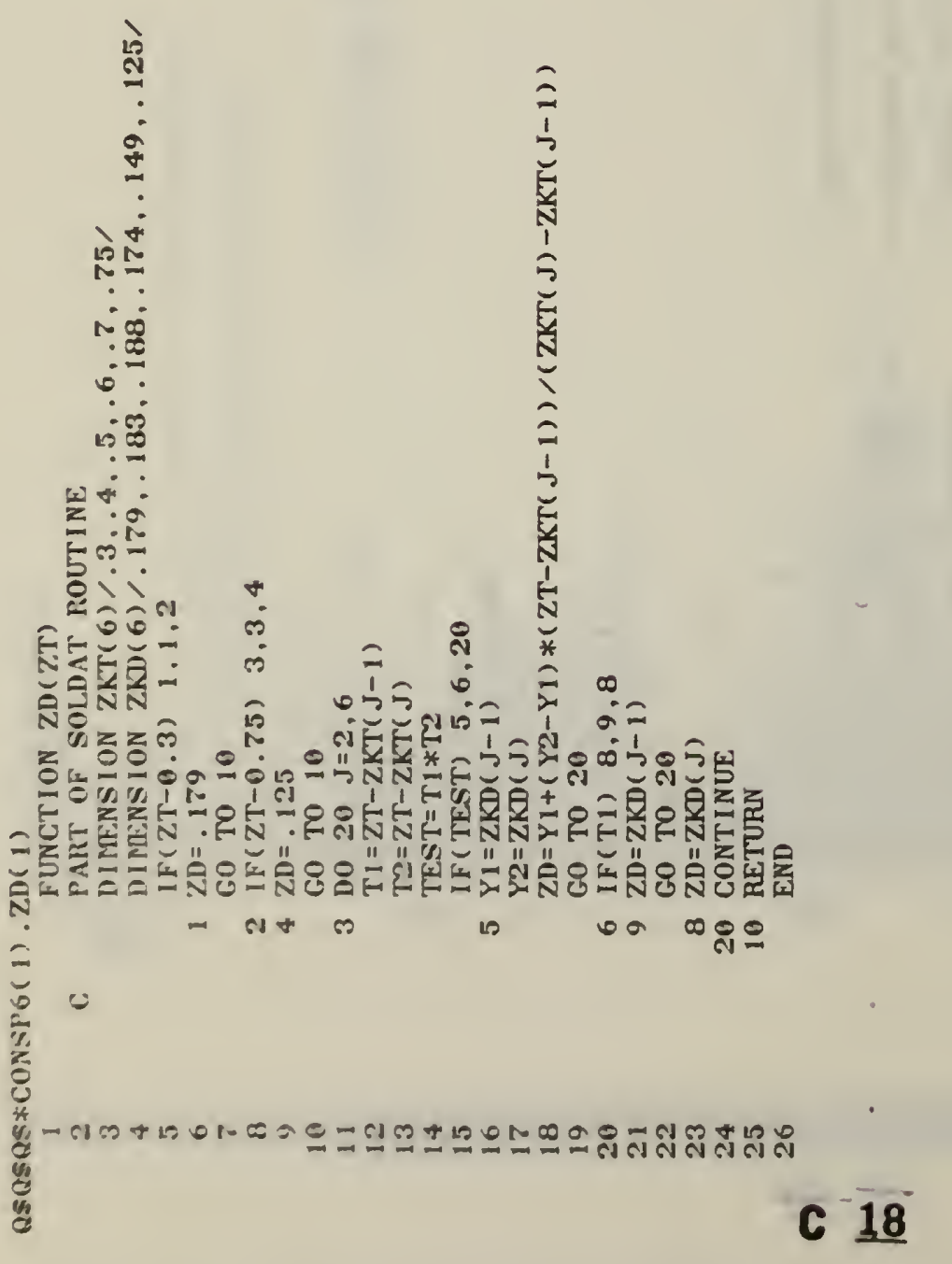




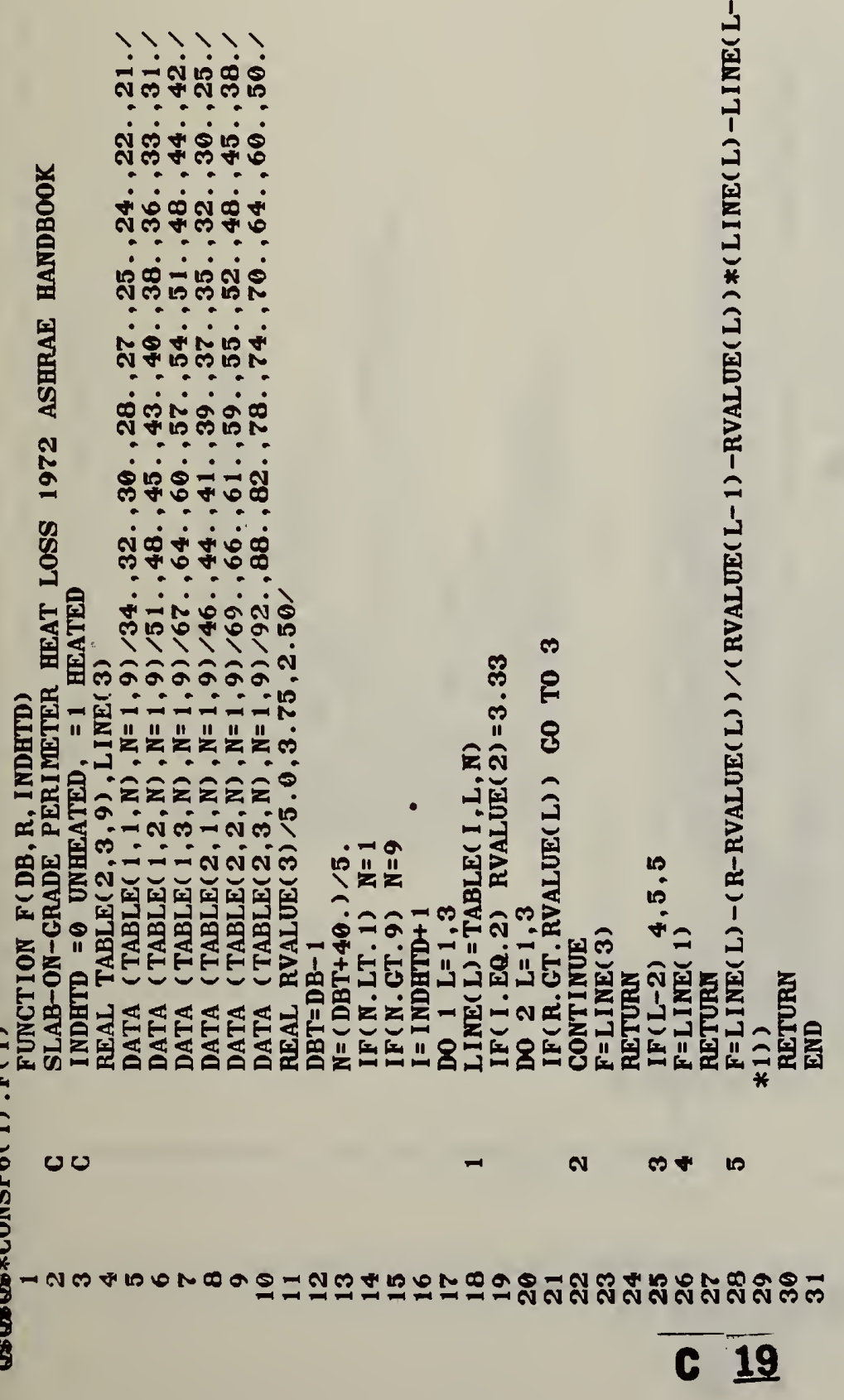




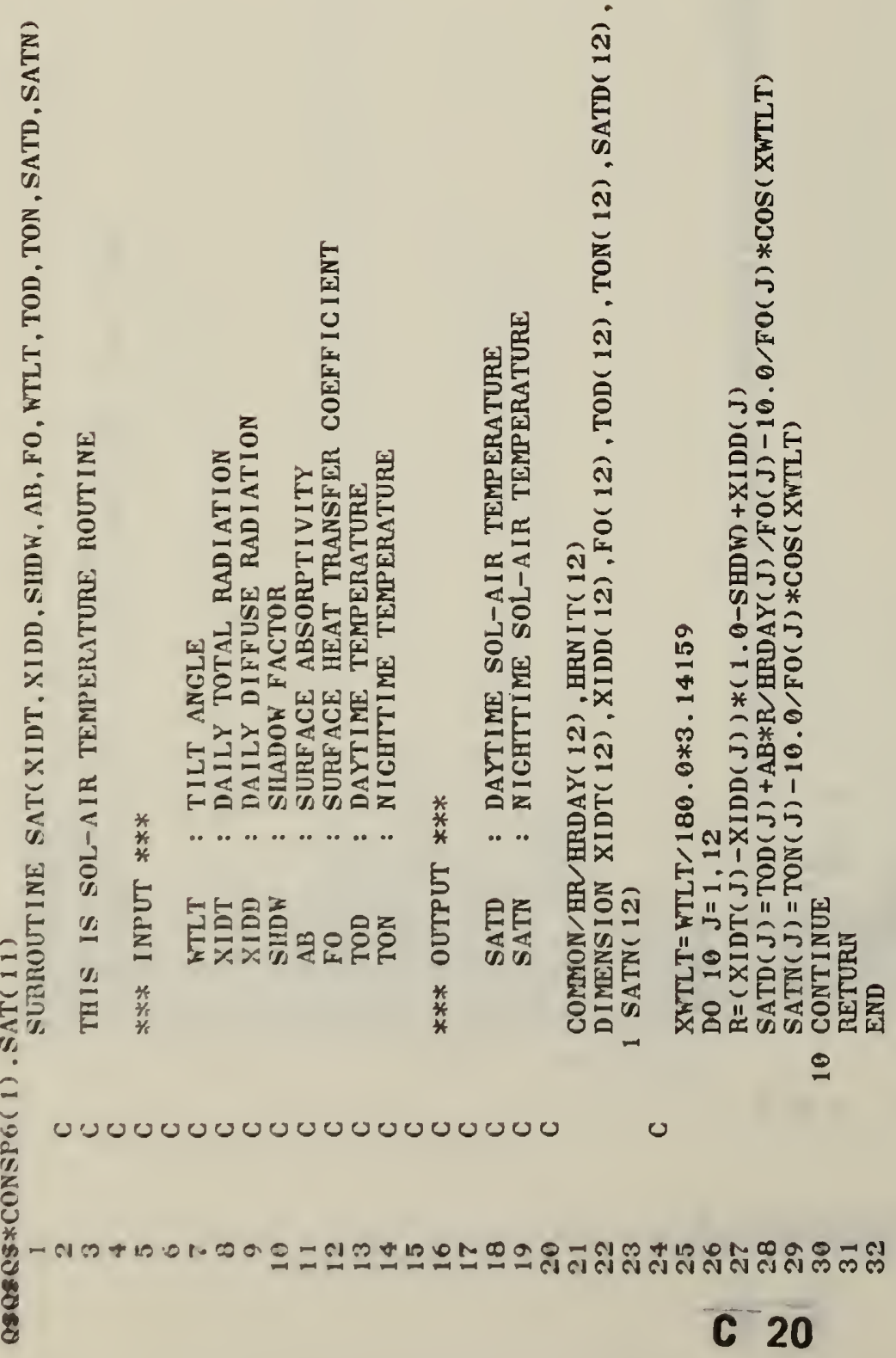




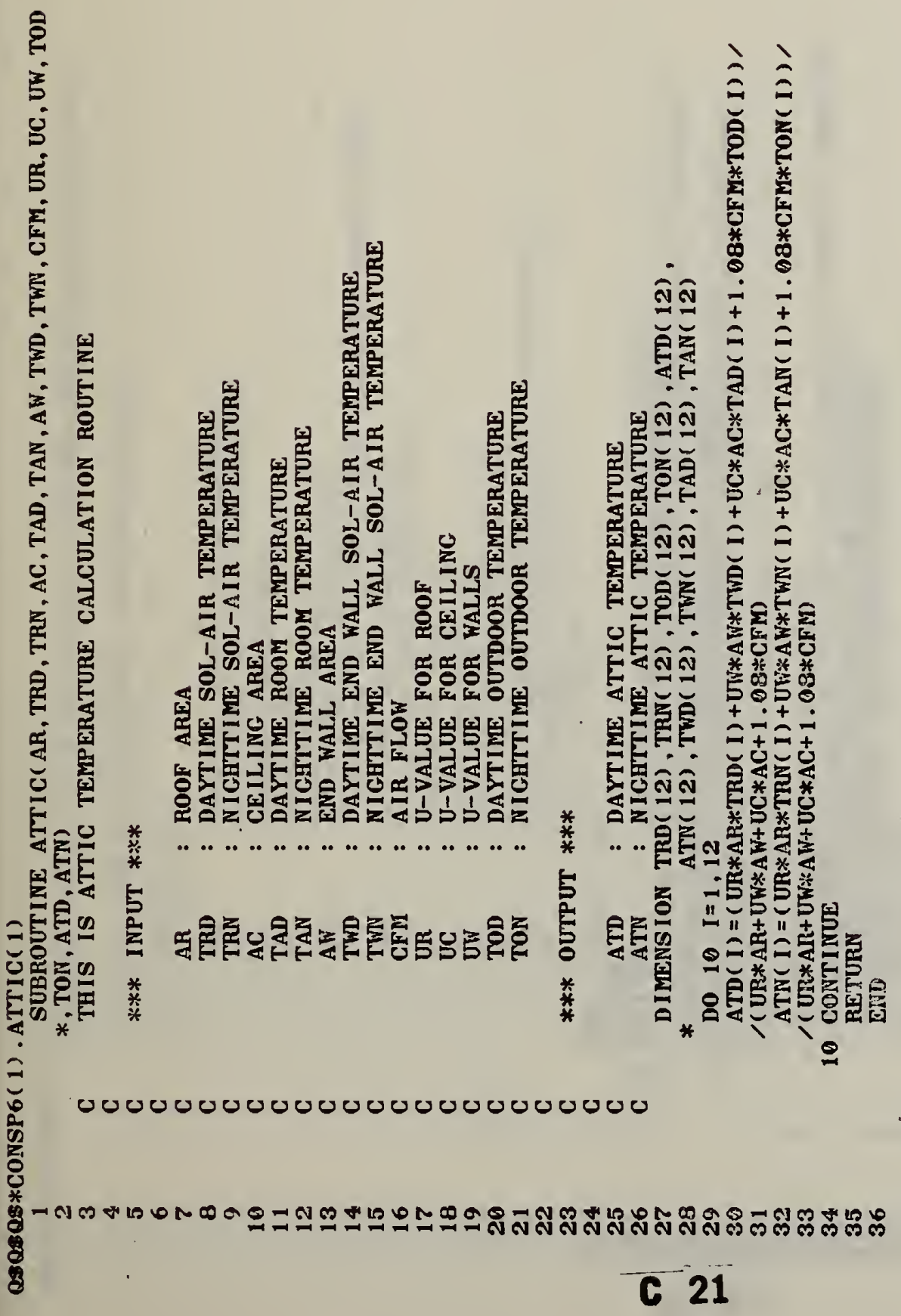




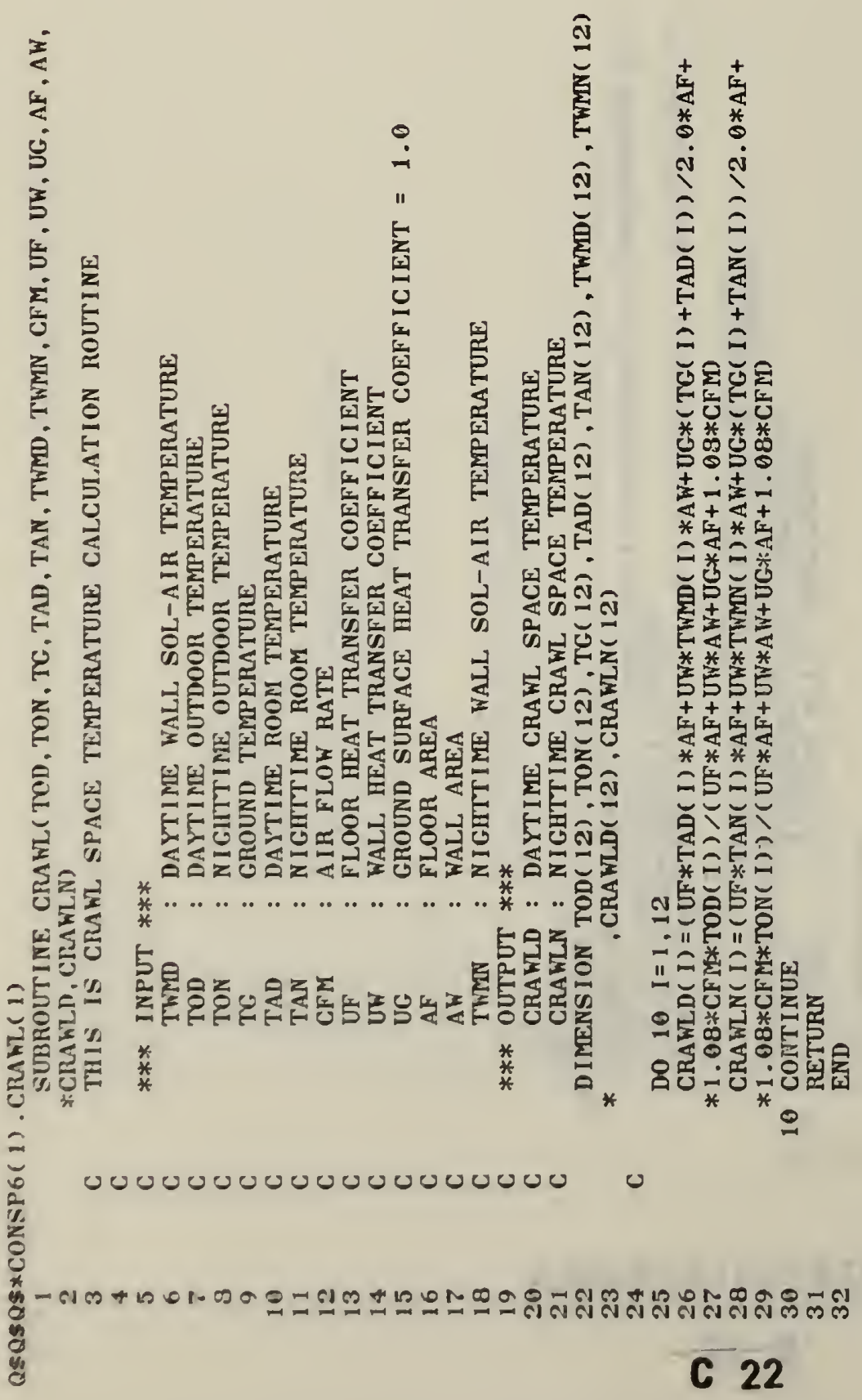




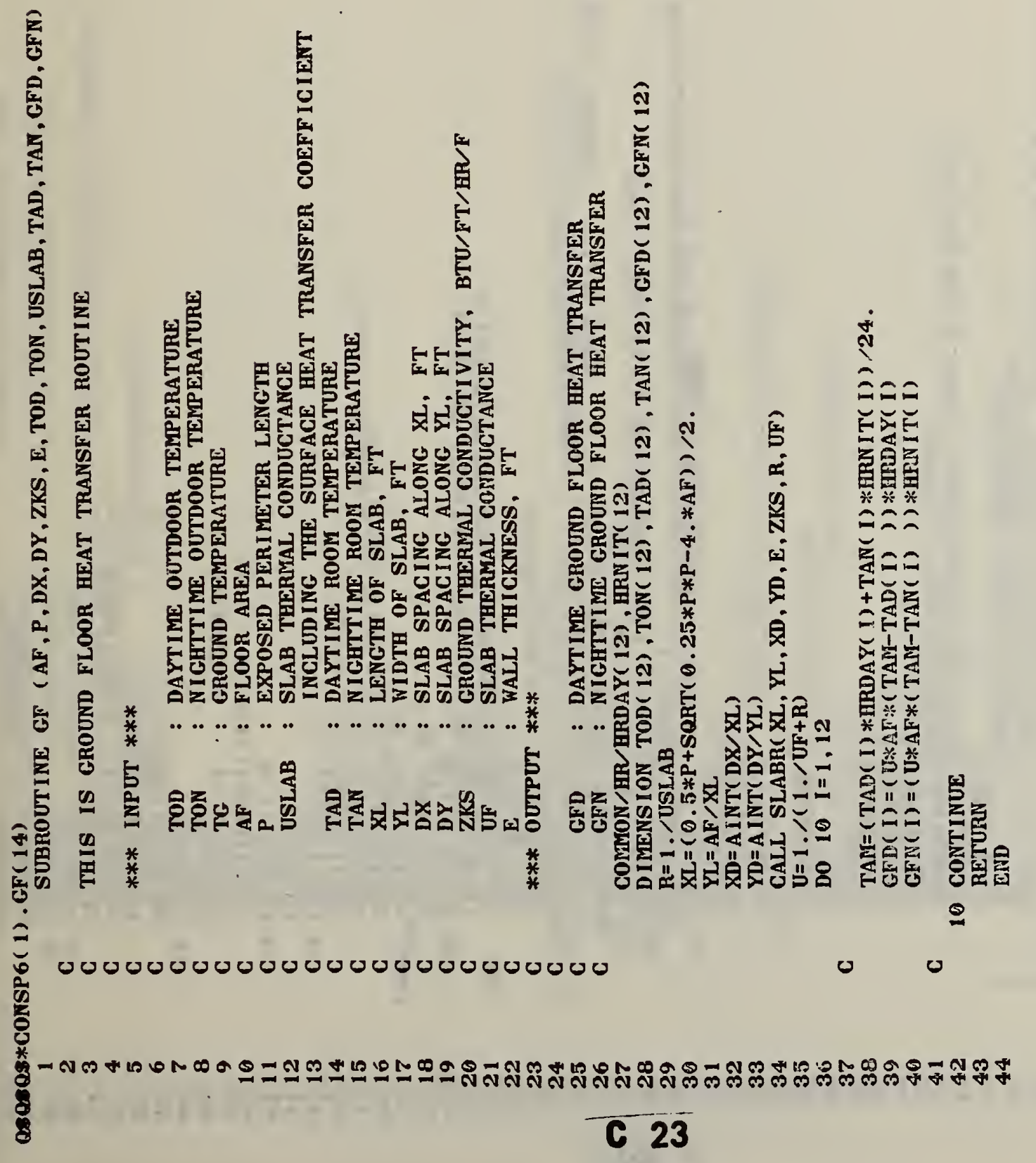



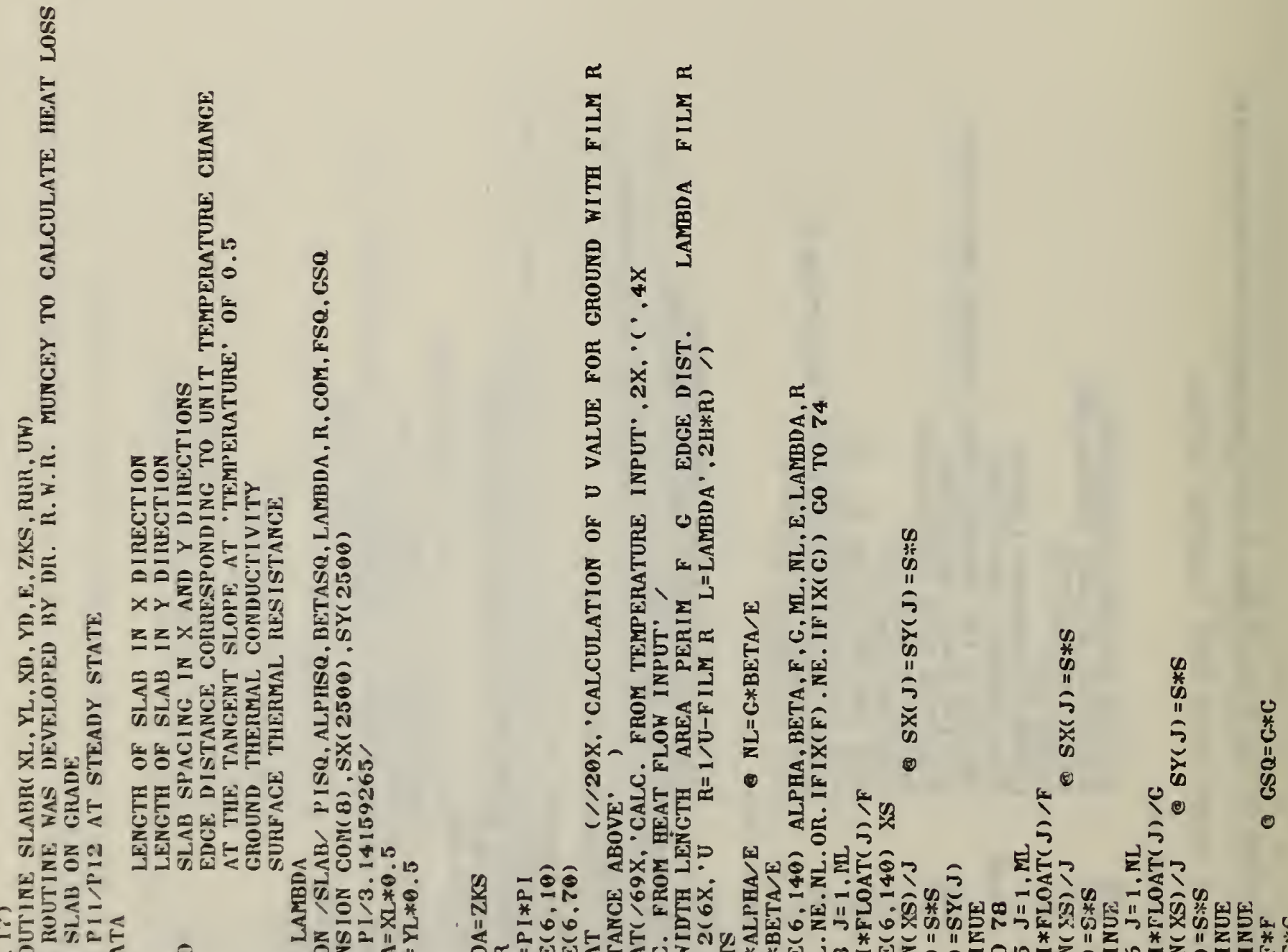
造
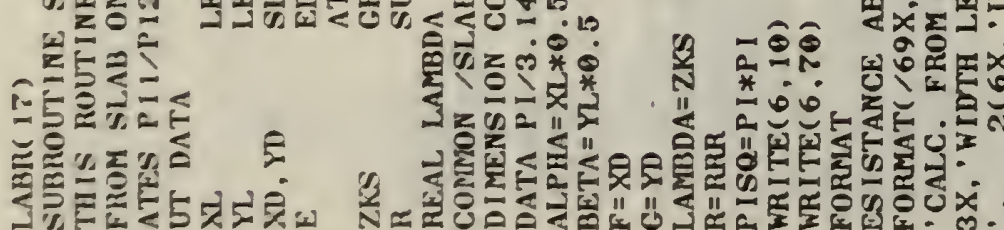

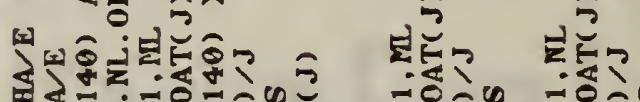

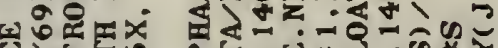

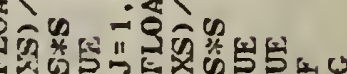

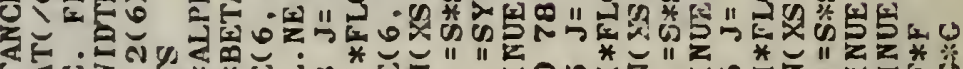

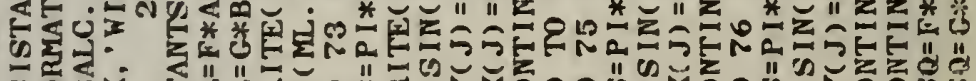

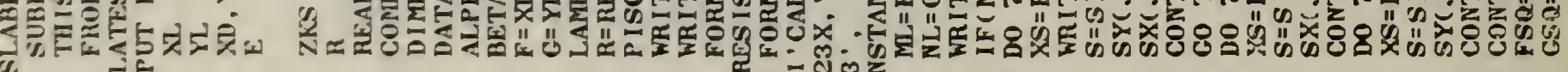
Do 


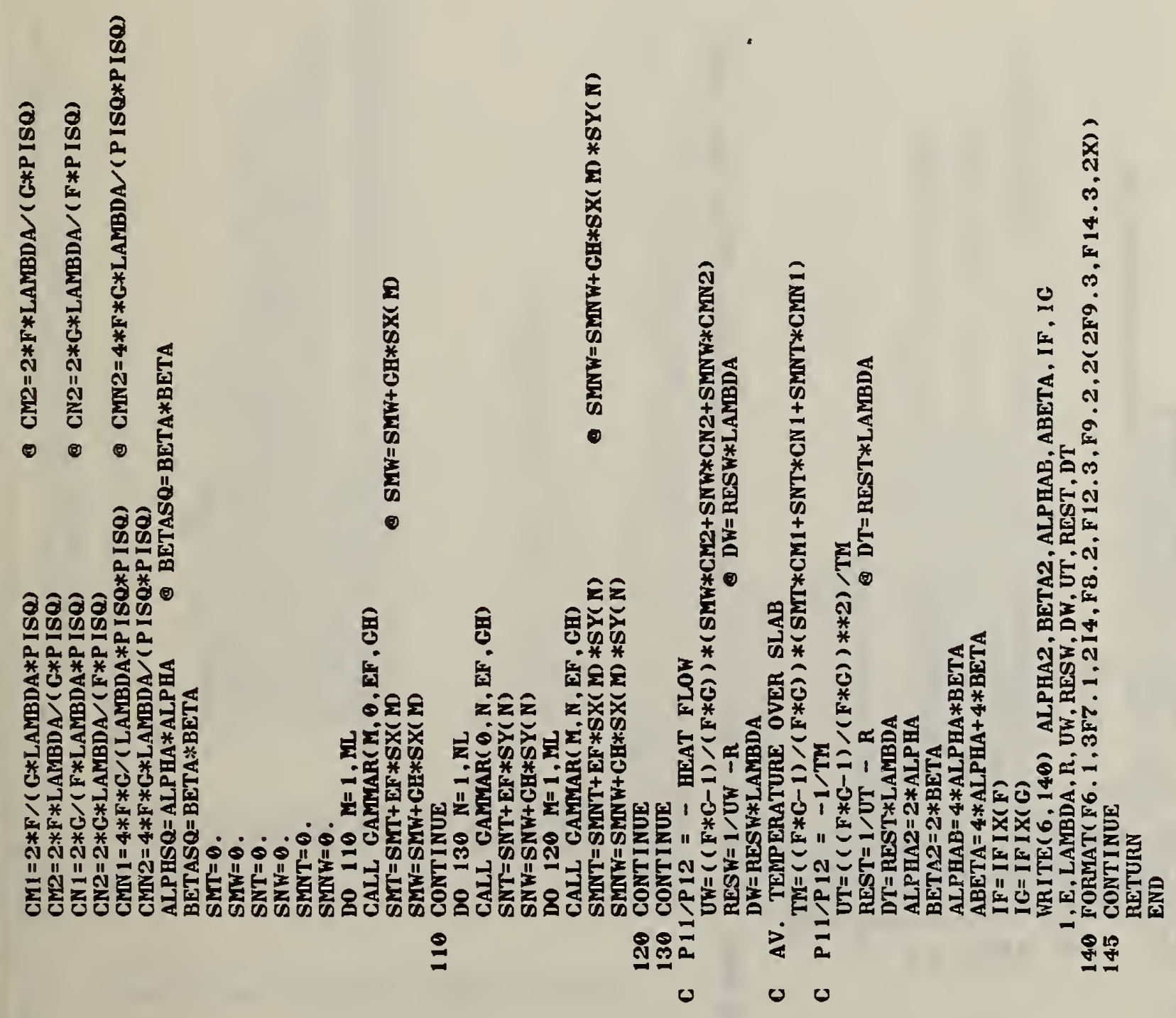

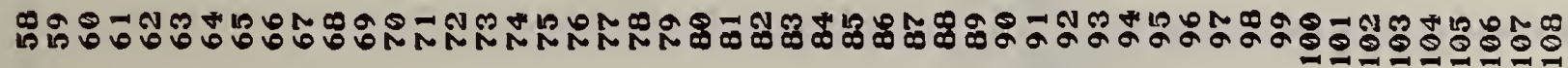




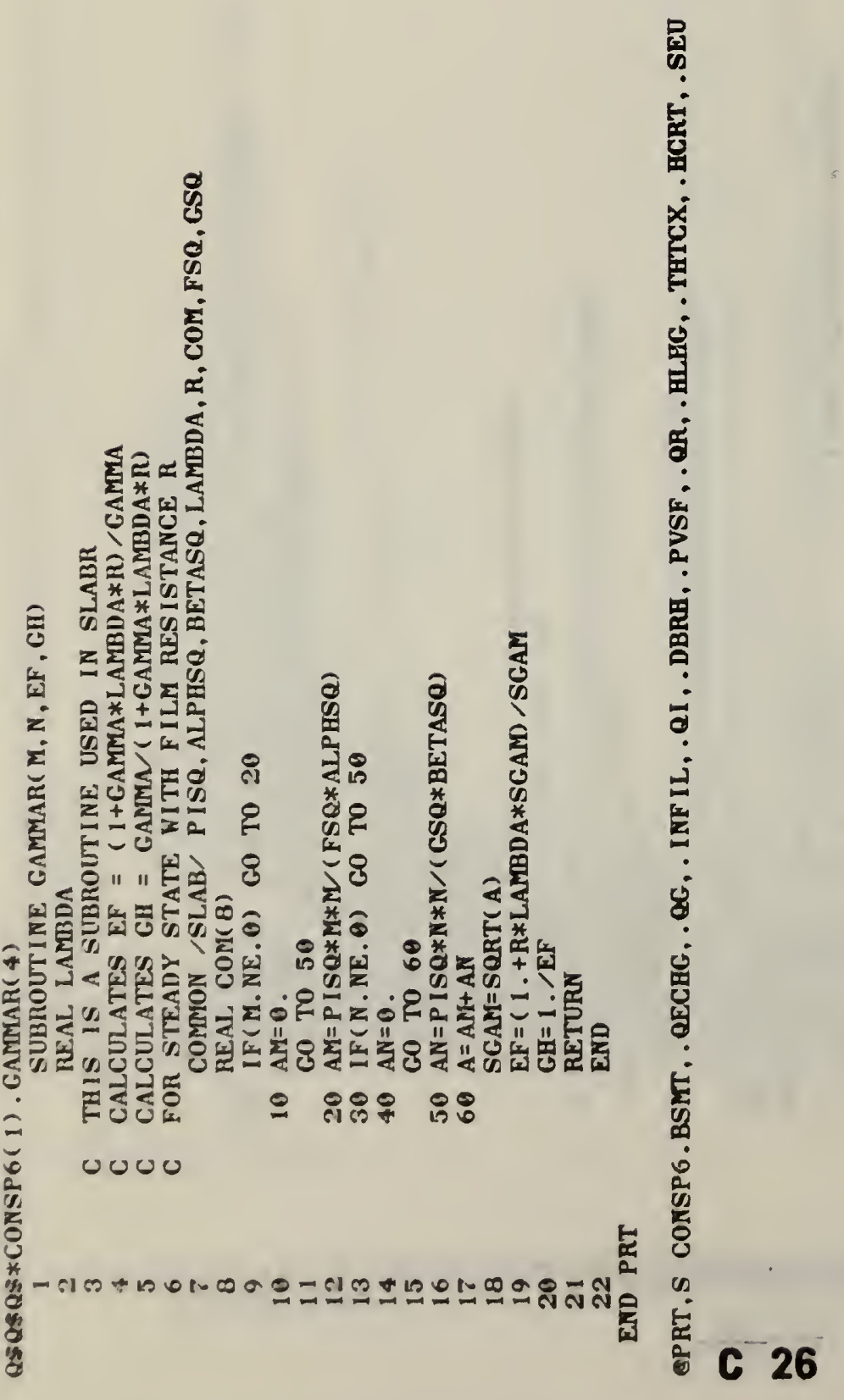




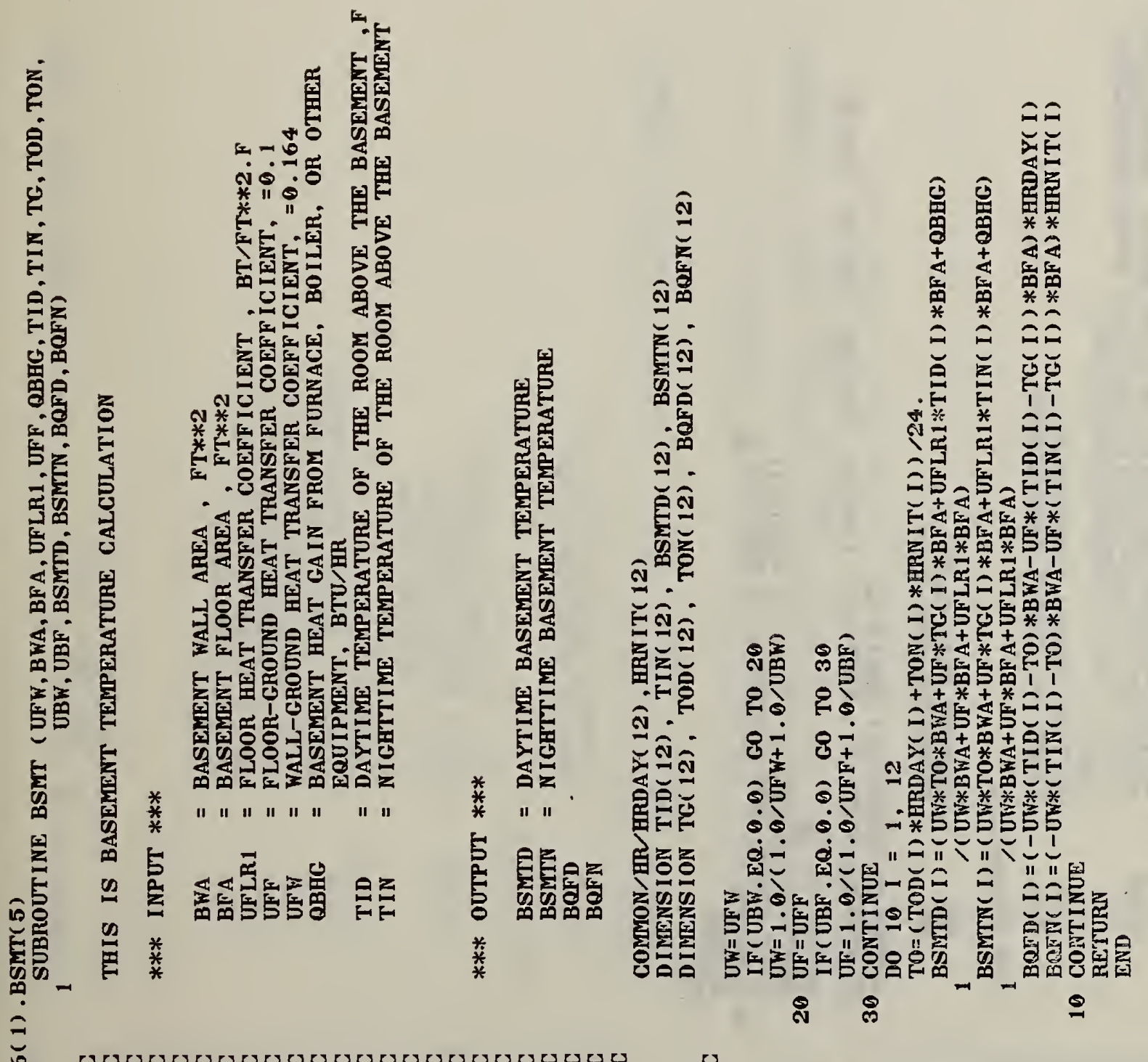




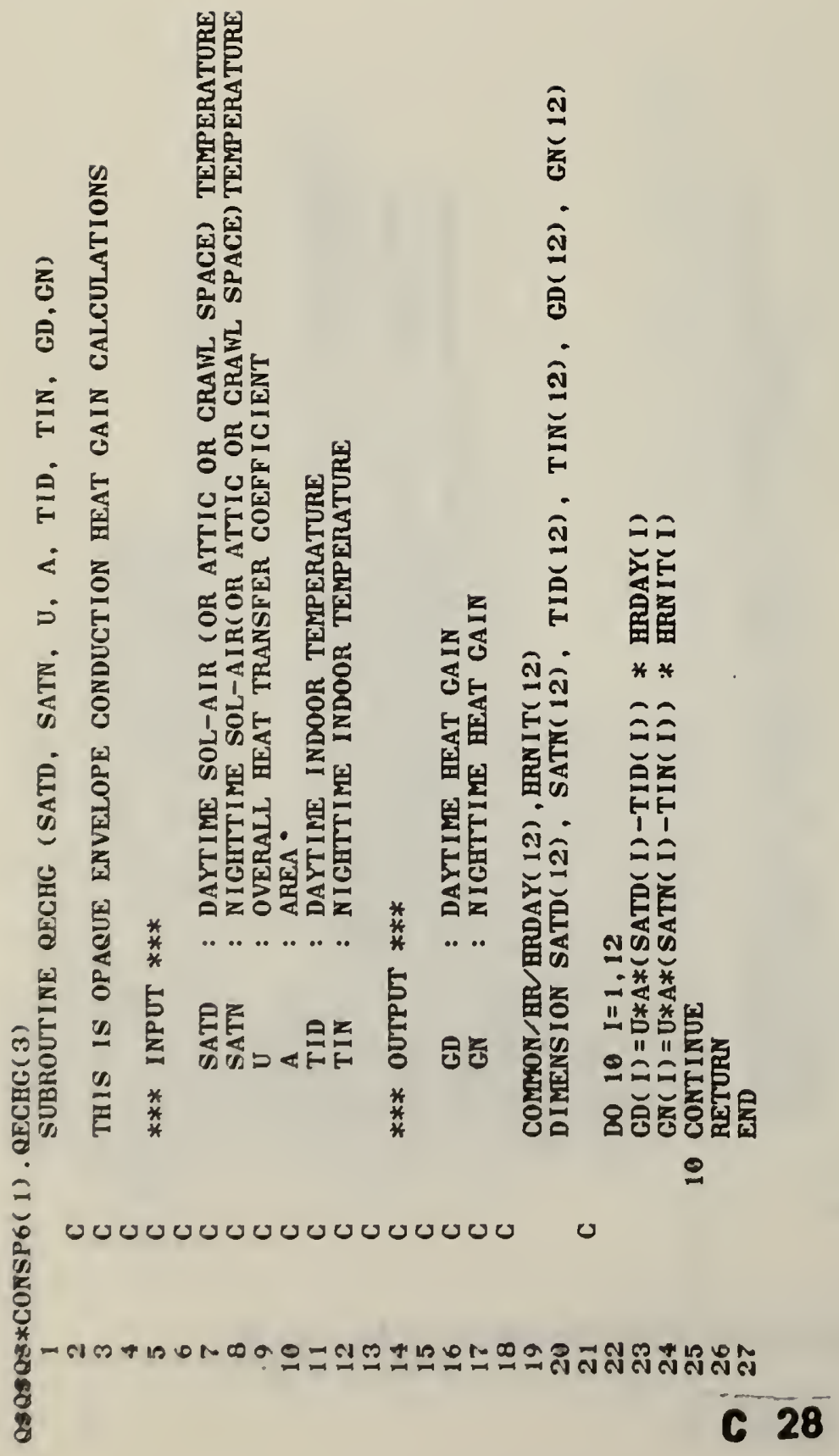




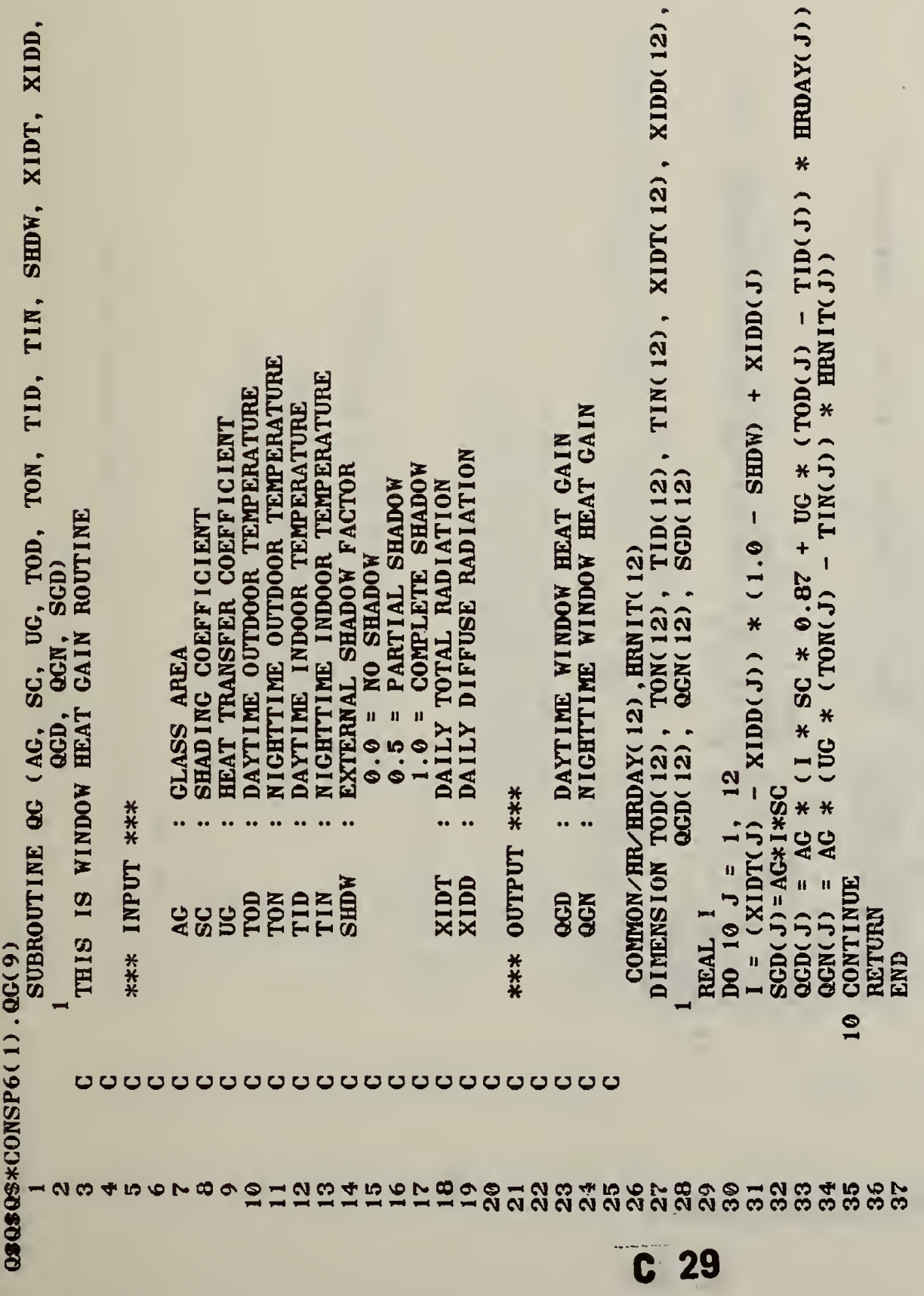




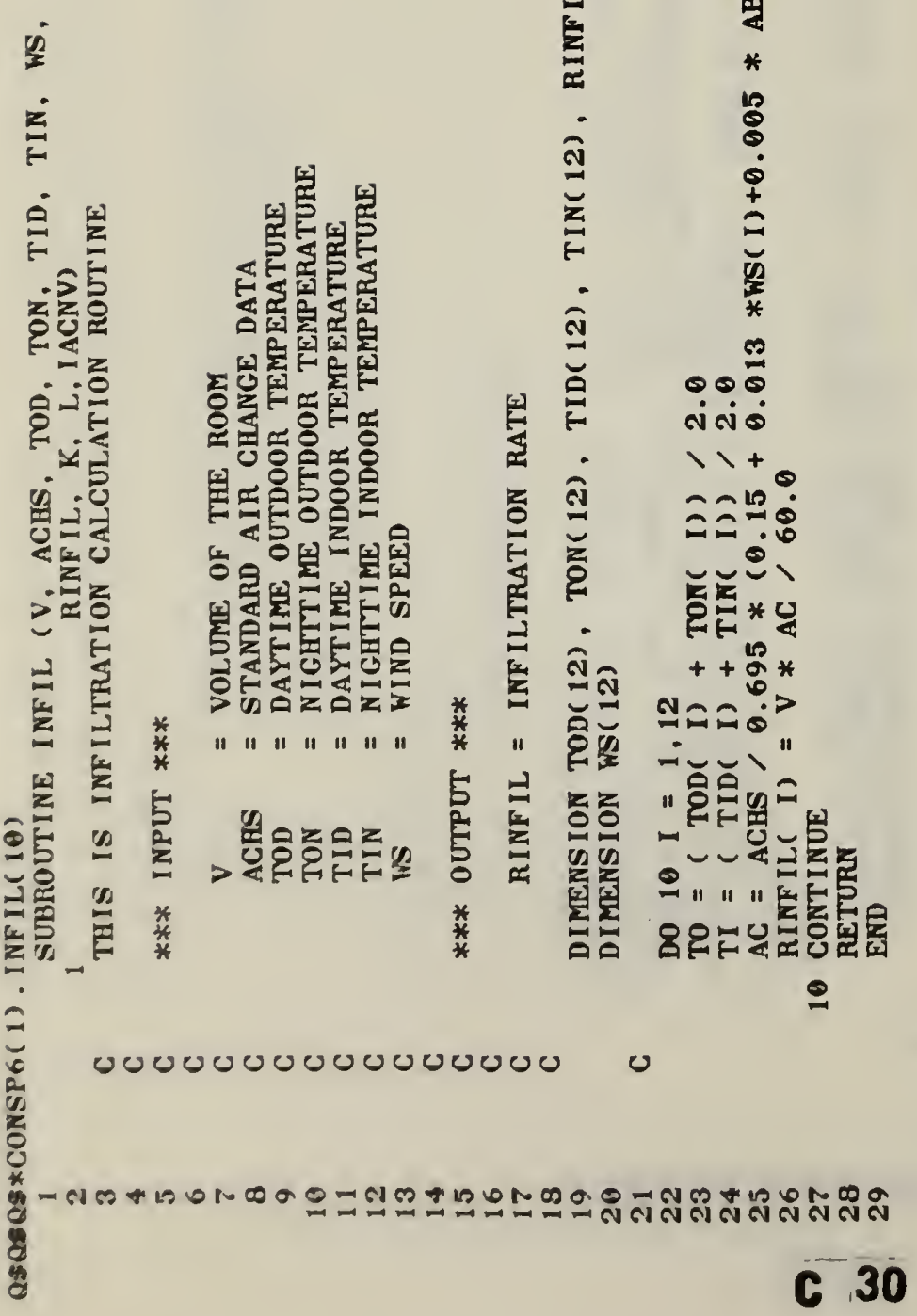




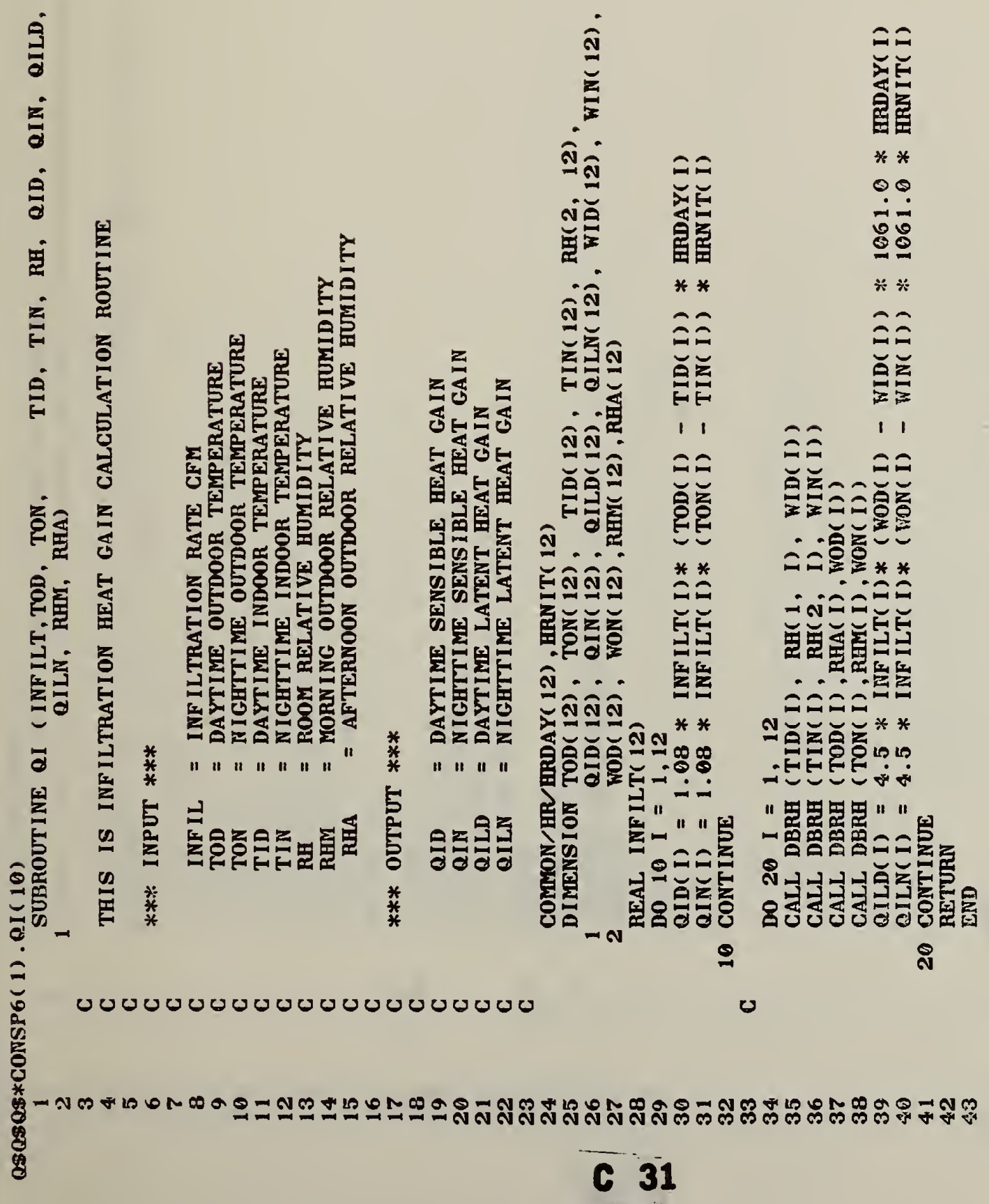




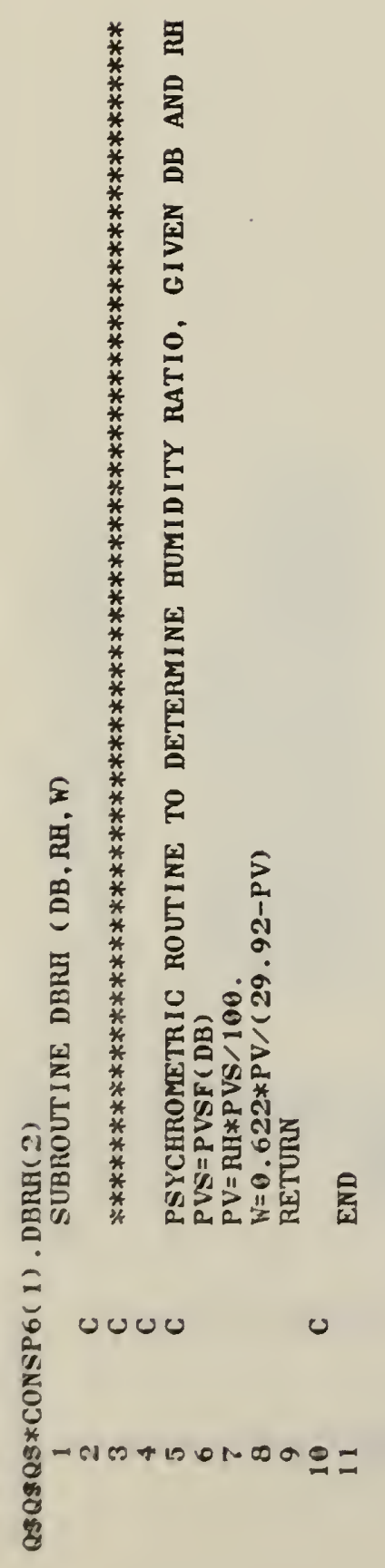




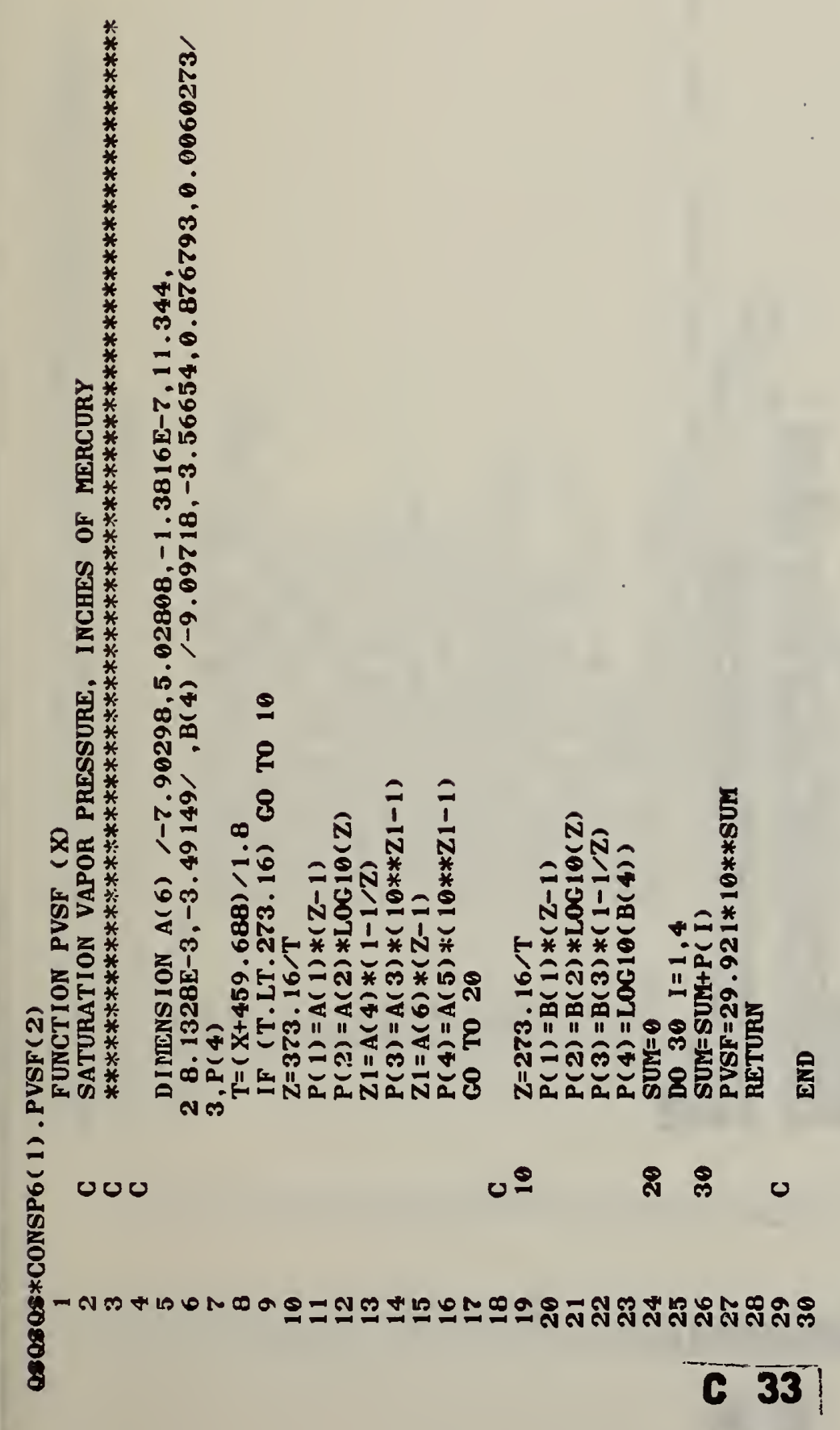




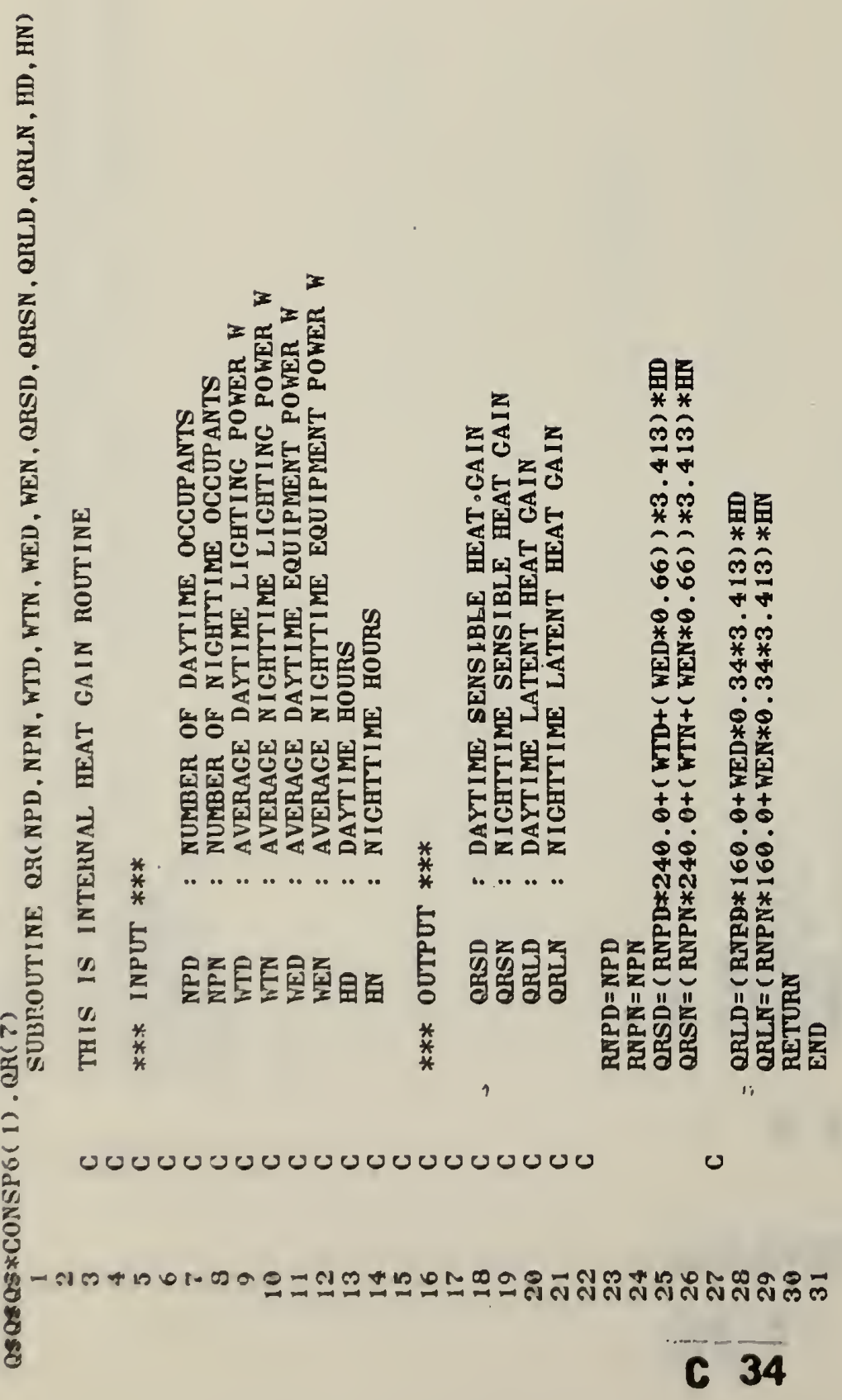


窟

国要

造密

부요

स्थ

悉

농

畄窎

它官

急

s.

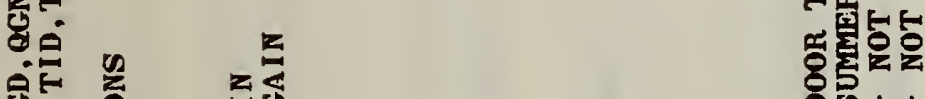

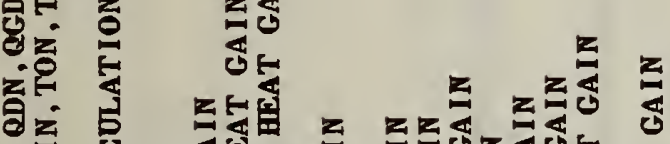

8

:

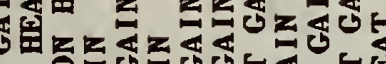

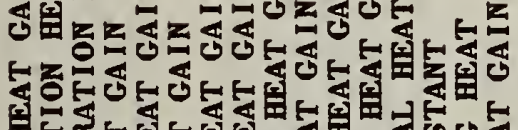

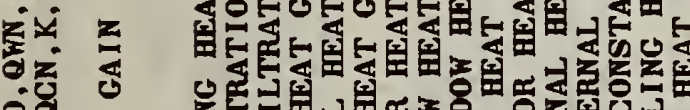

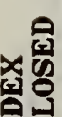

客是

I

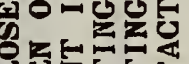

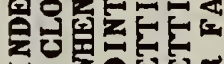

运氞四

중

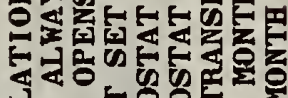

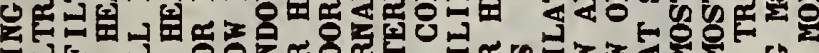

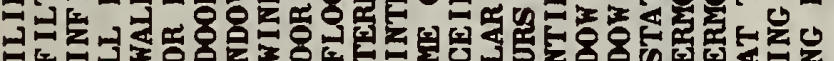

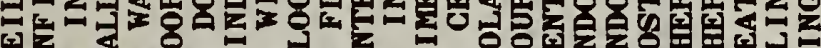

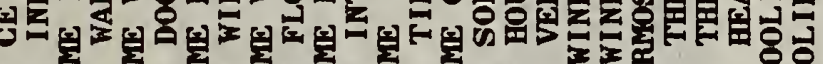

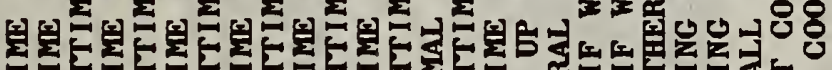

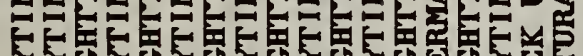

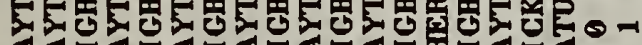

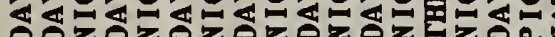

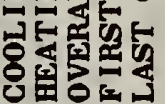

氜

国完

*

될웡

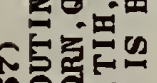

is ô.

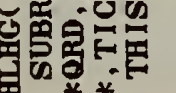

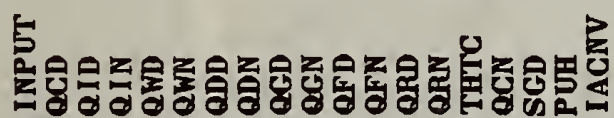
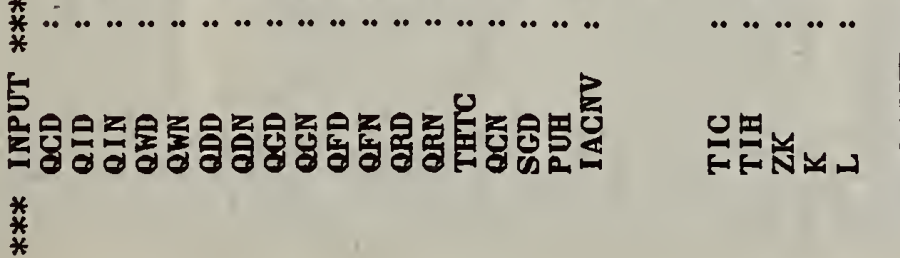

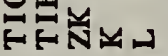

원

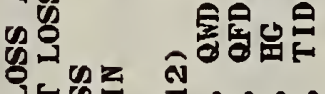

N

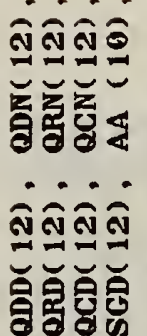

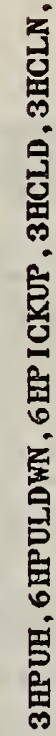
$\rightarrow$

5

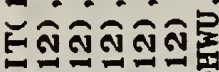

서순

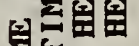

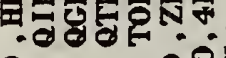

要为

대열

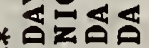

ลิ … ลิ

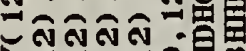

ここここ栗

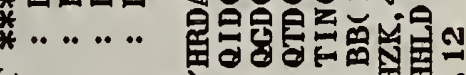

:

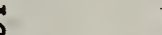

通总

\ڤ

응동협

*

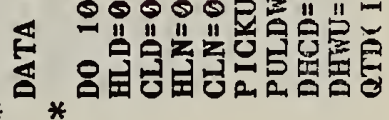
$* * * *$

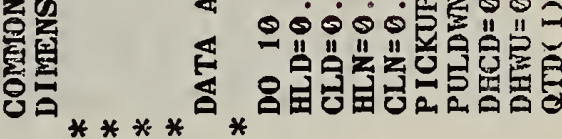

000000000000000000000000000000000000

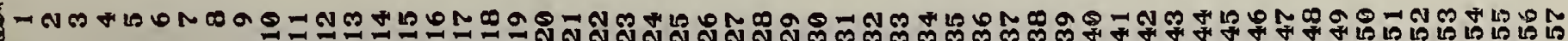




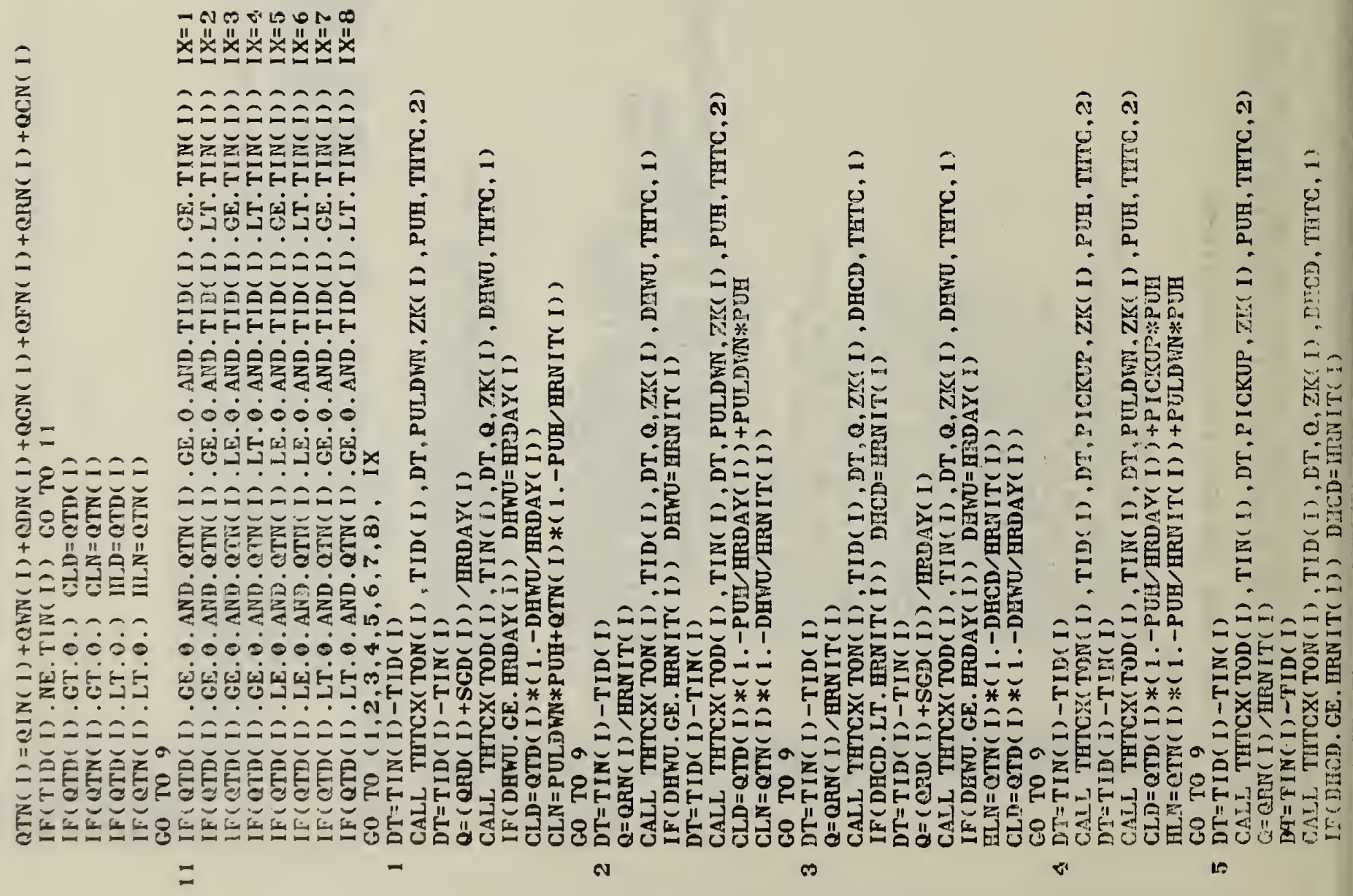

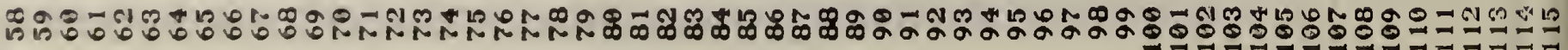




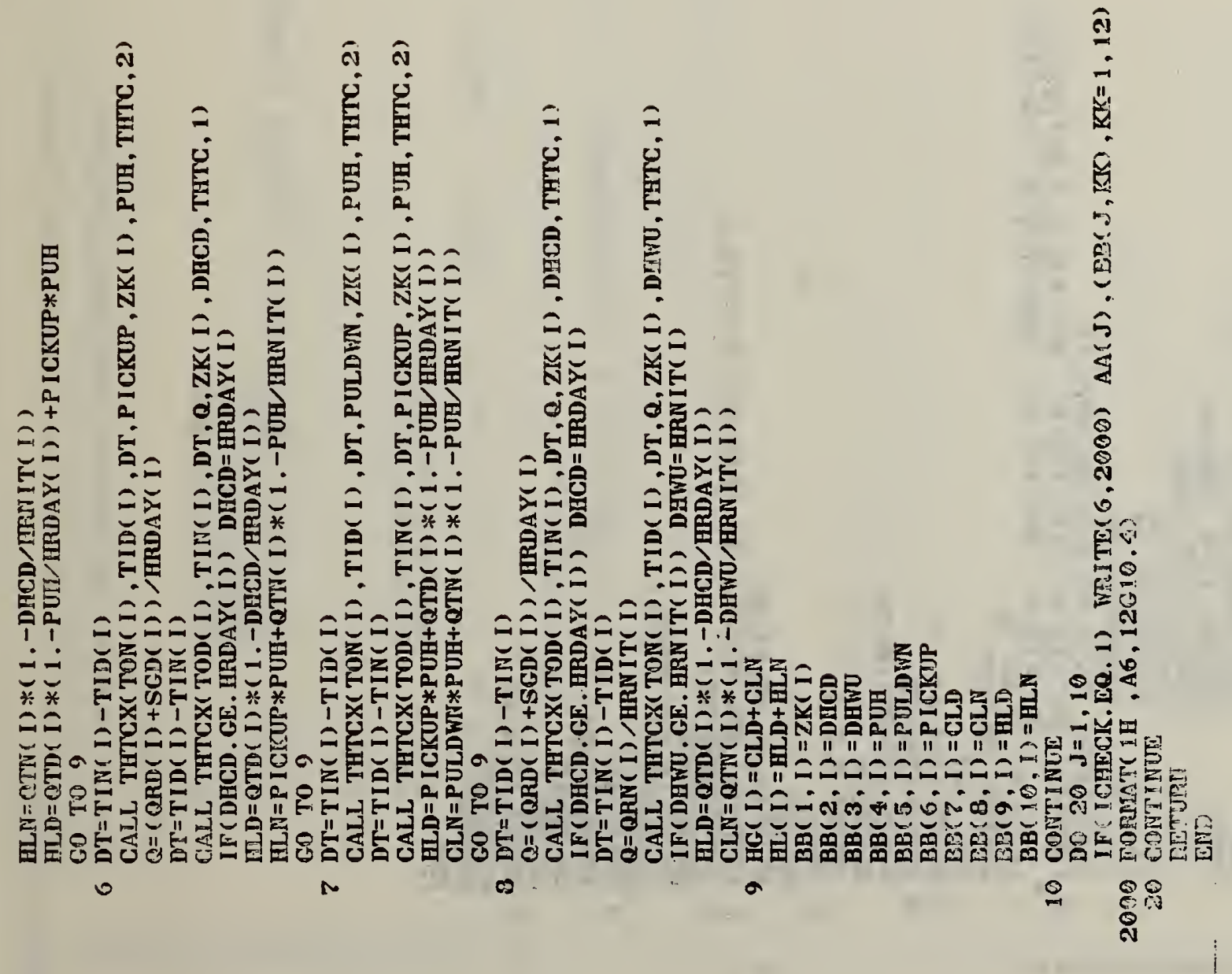

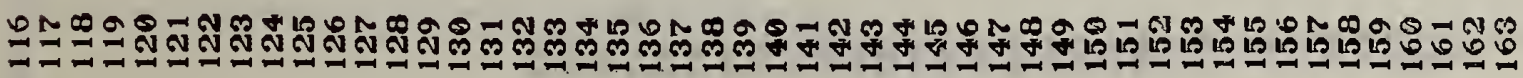




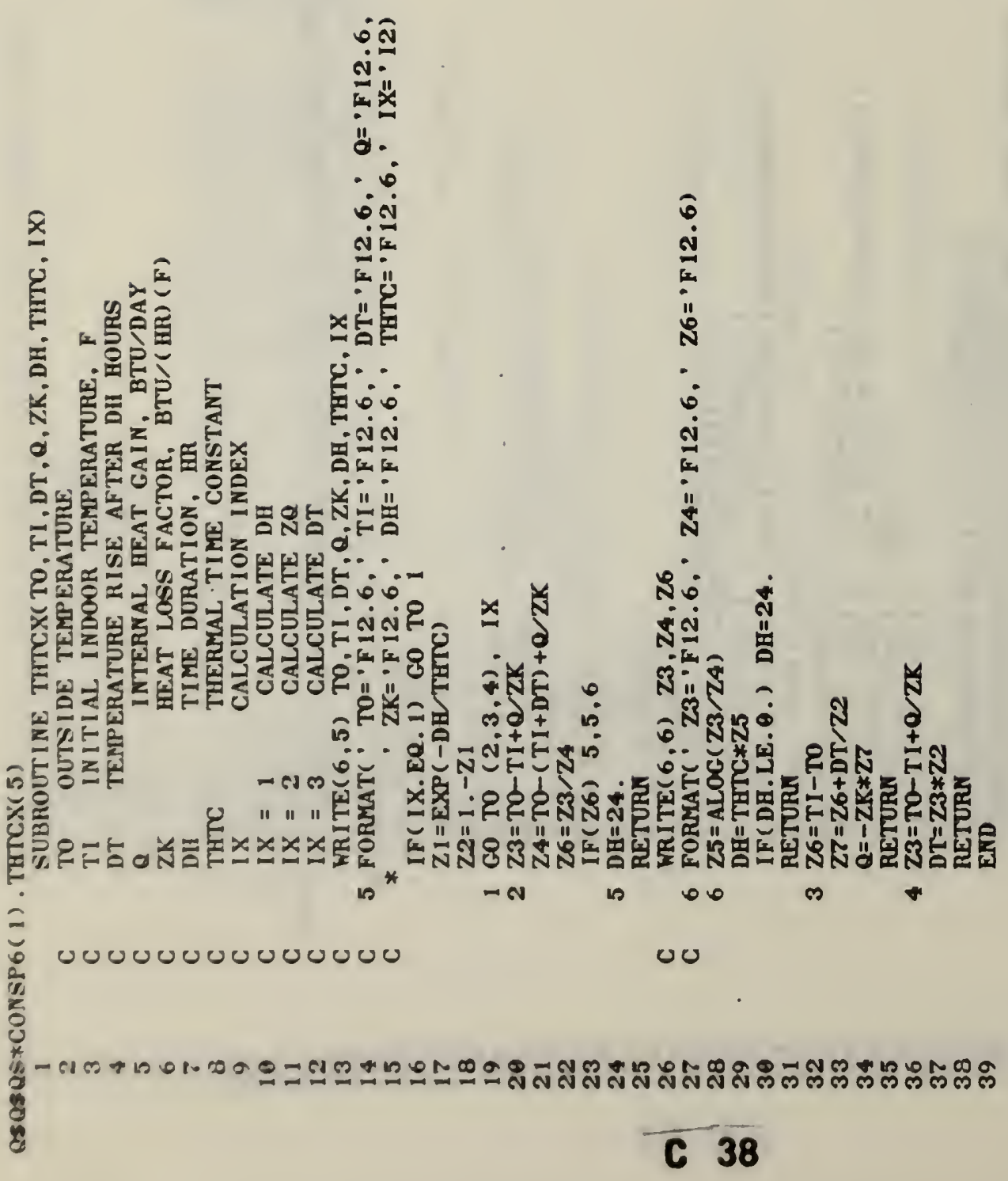




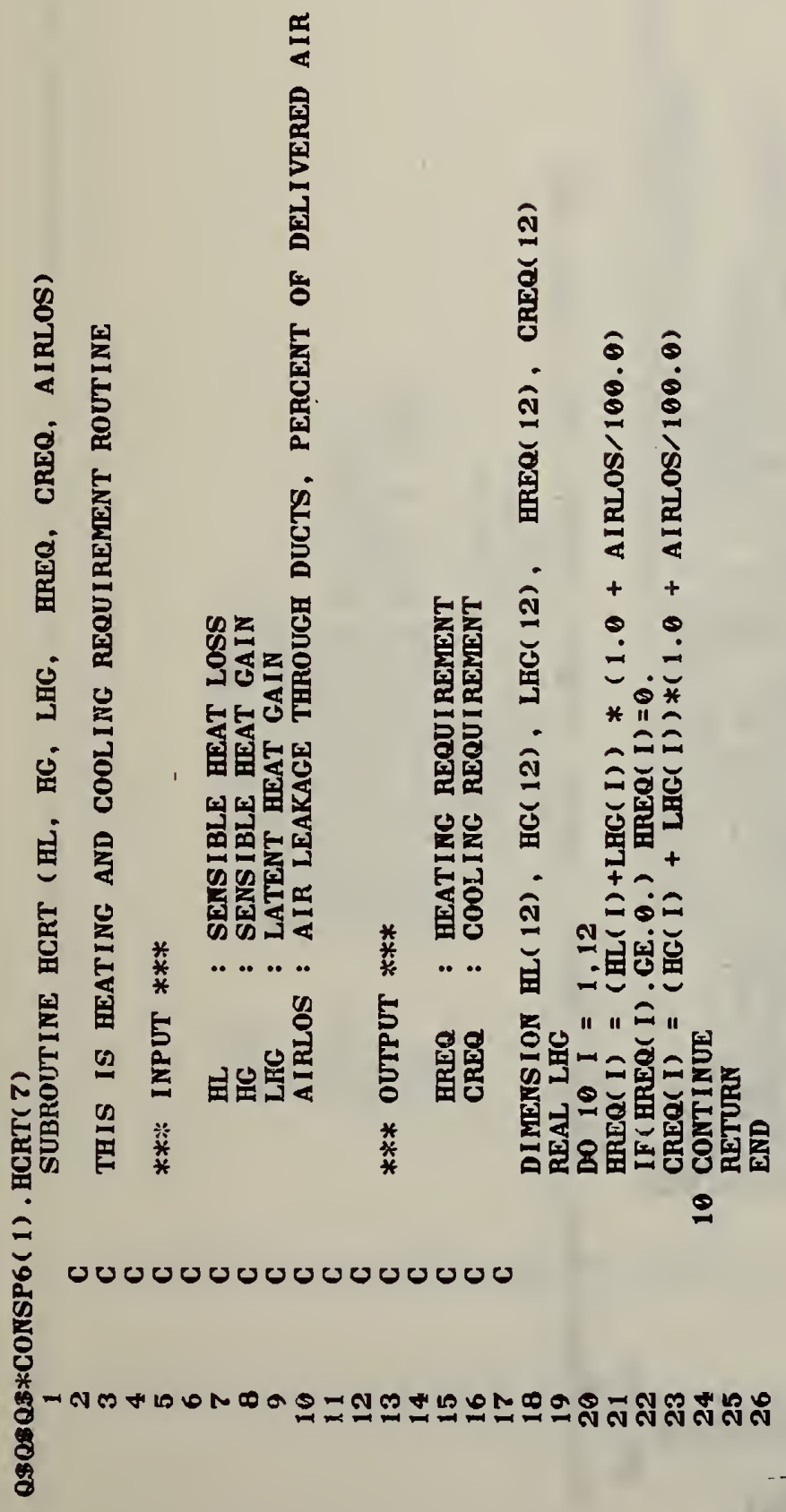




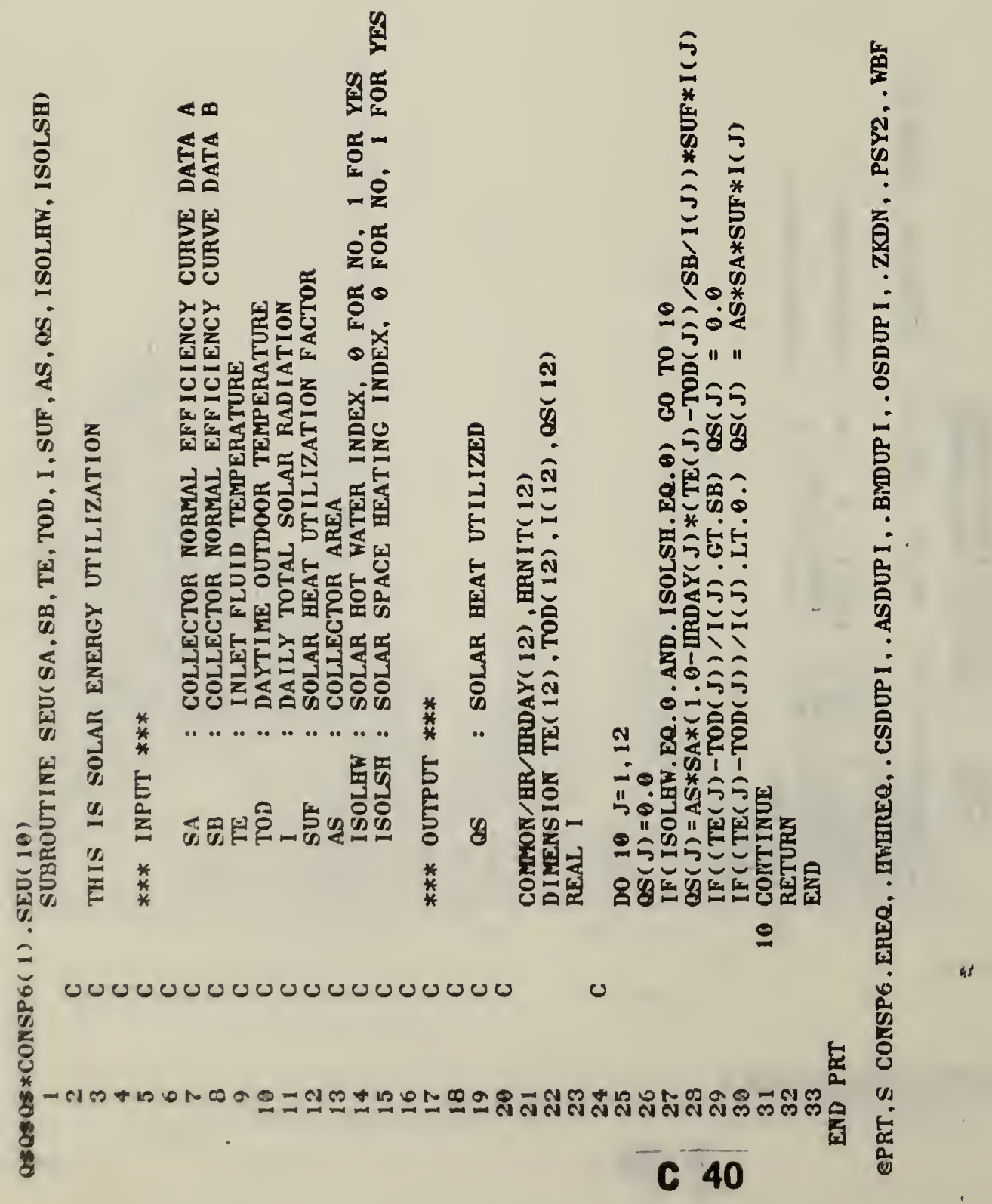




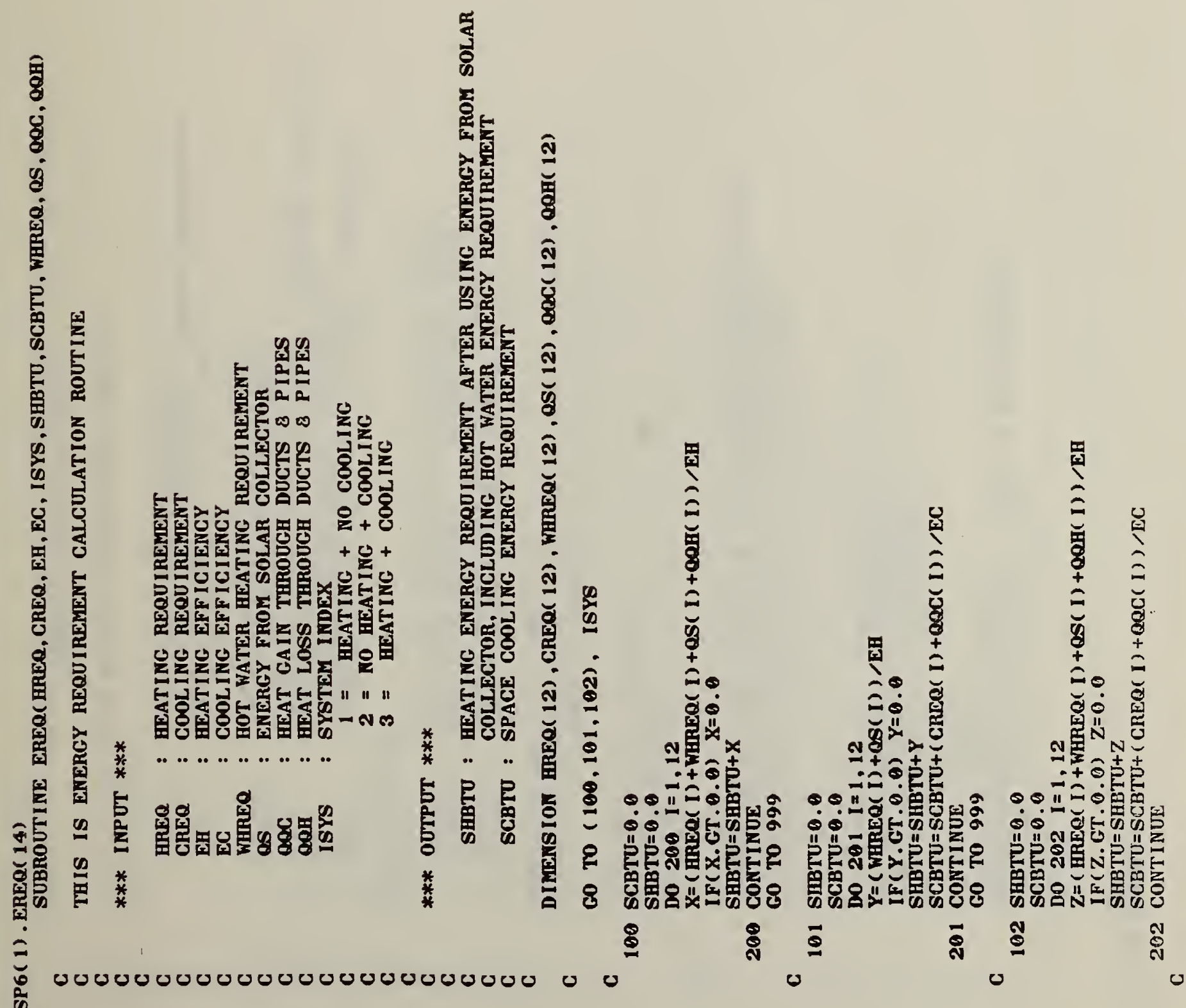




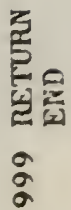

ต็ำ

C 42 


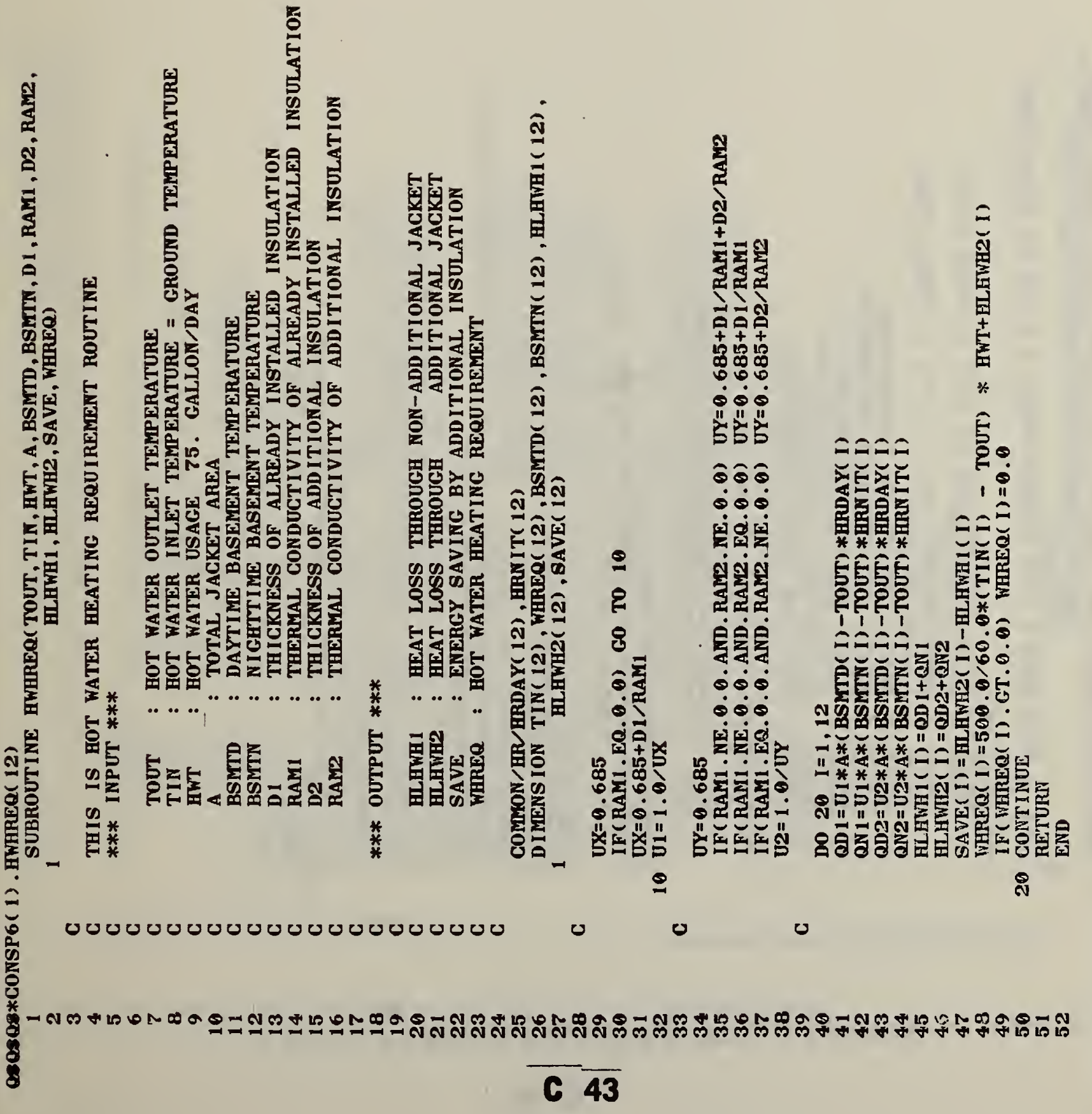




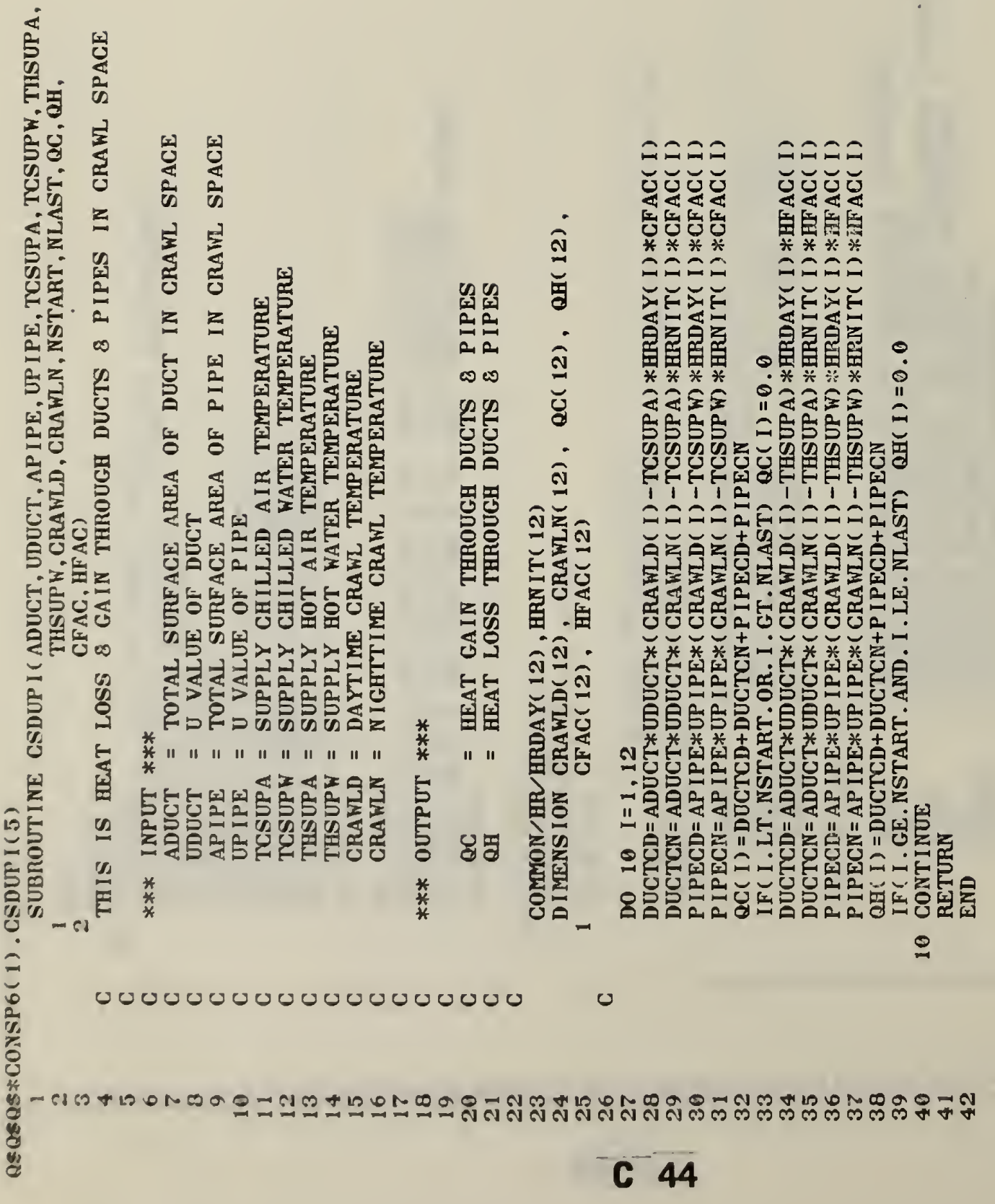




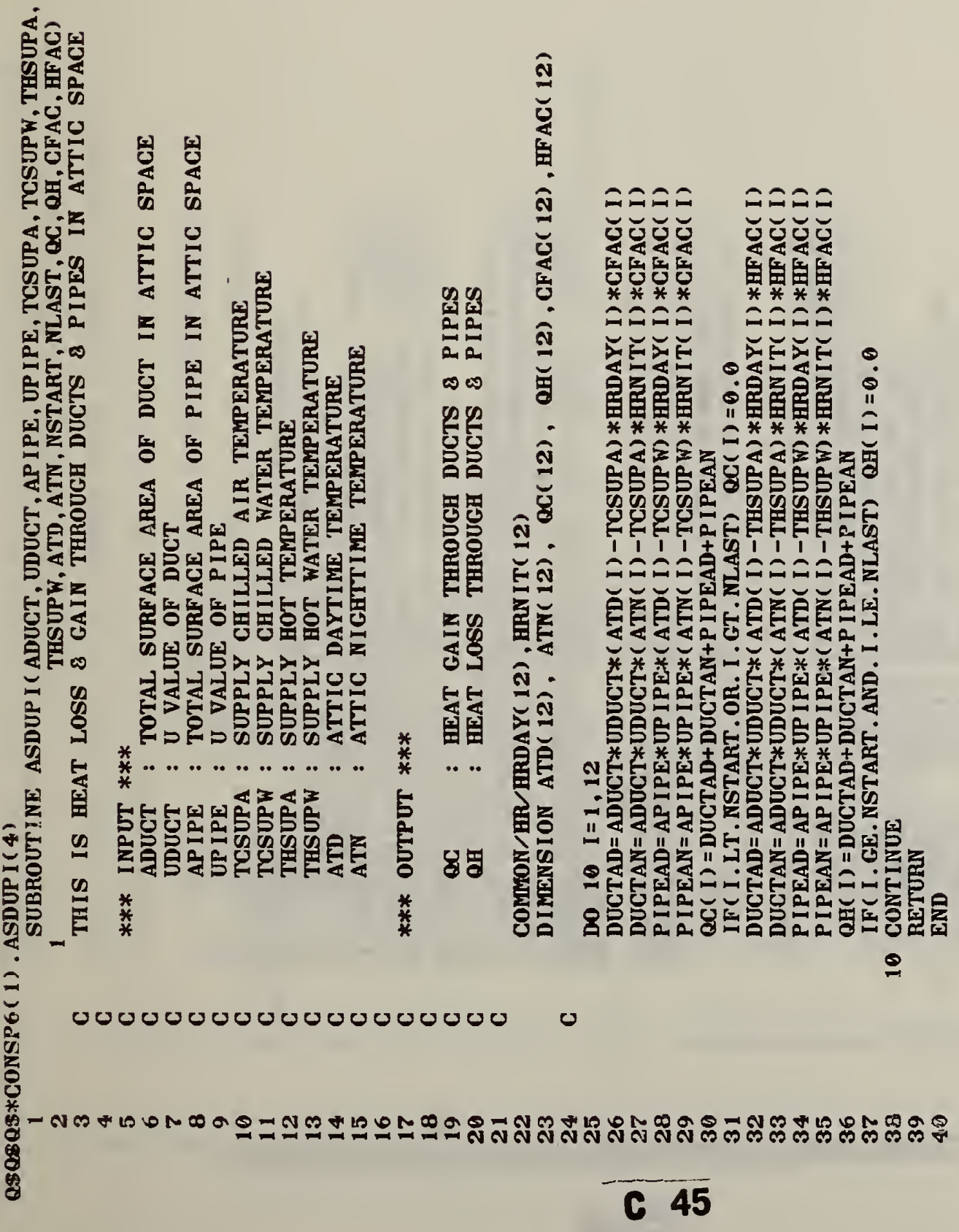



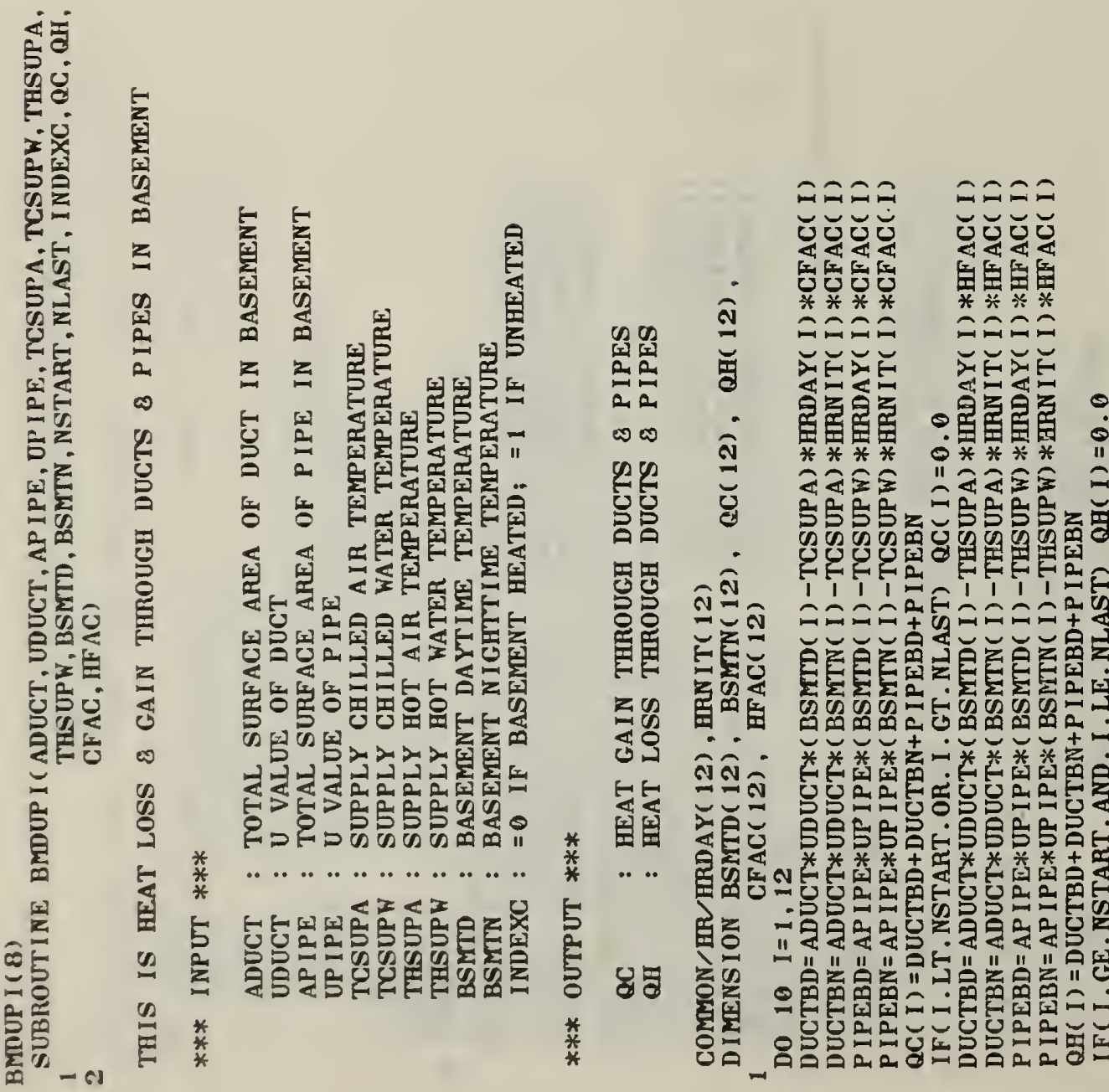

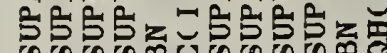

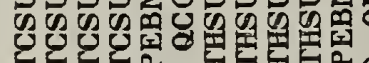

붕 ลิง

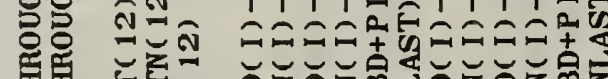

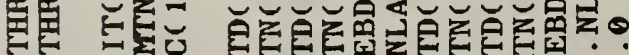

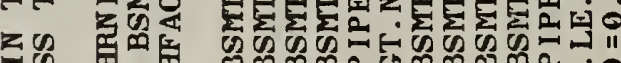

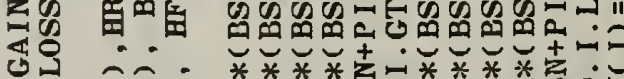

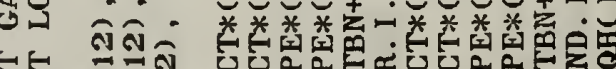

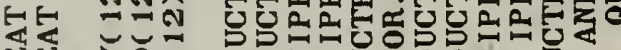

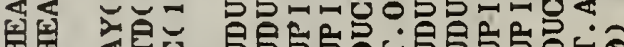
TU OSS

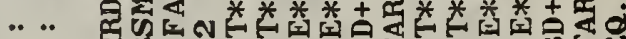

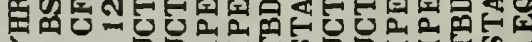

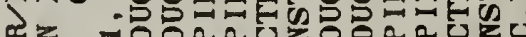
息各 ชำ

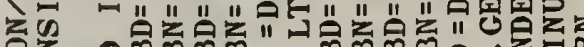
혼 올

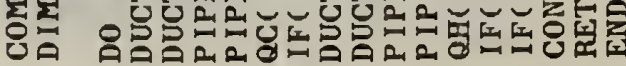

0000000000000000000000 

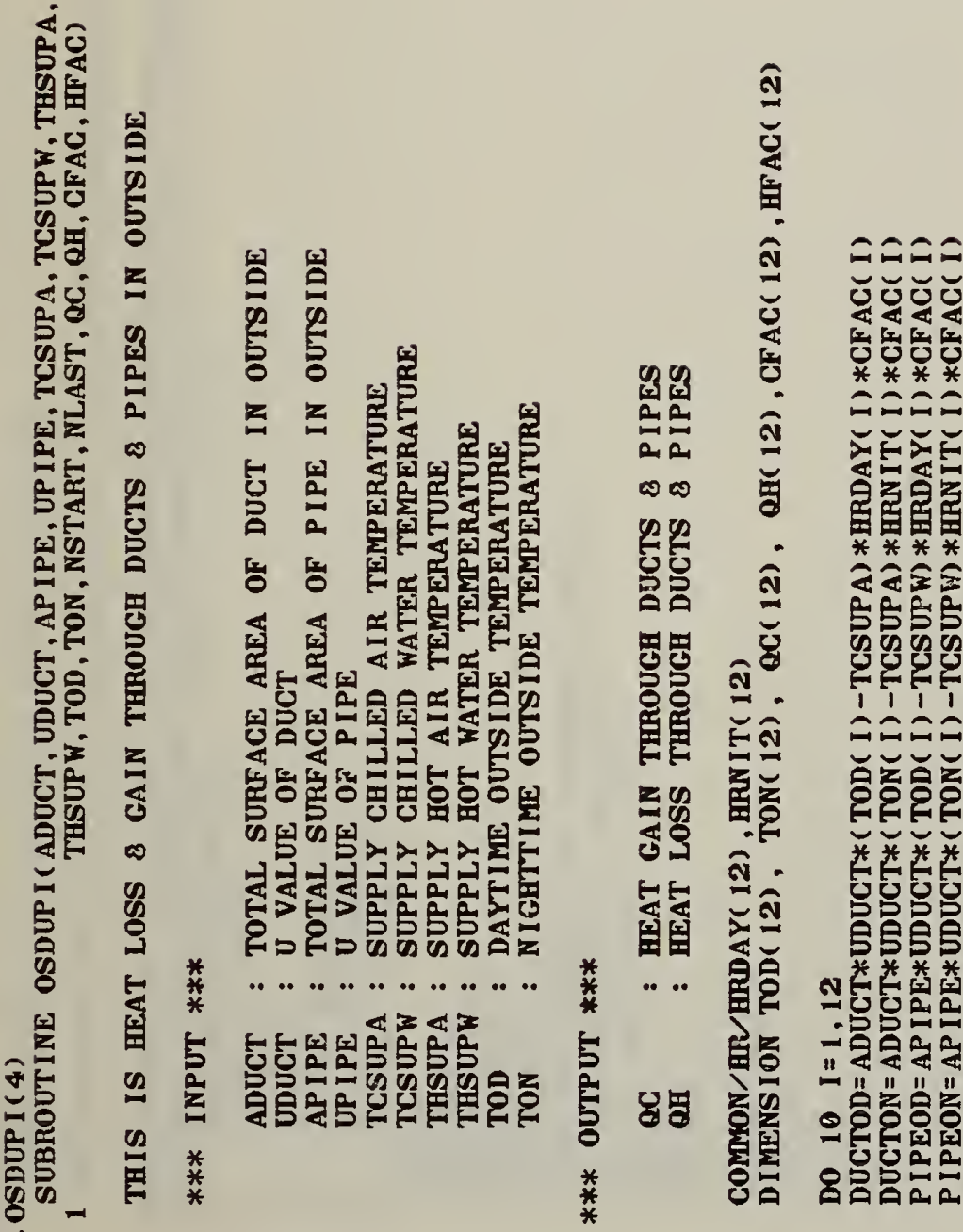

ニลลこ ชัญญ气

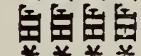

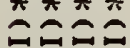
๑こここ

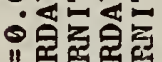
"둘⿷ㄹ 二*****十

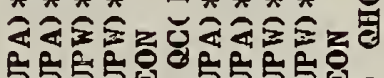

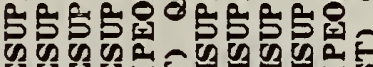

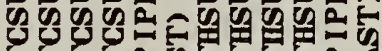

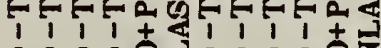

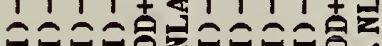

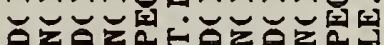

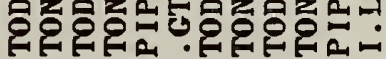

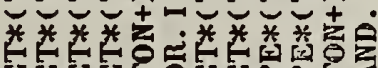

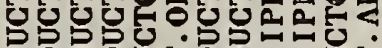

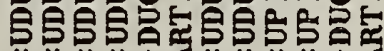

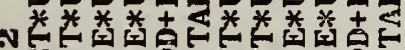

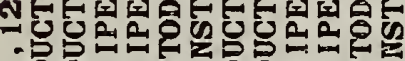

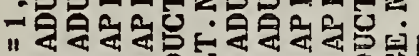
"1

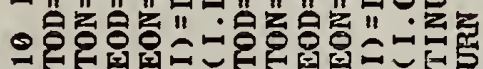

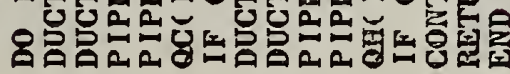

0 


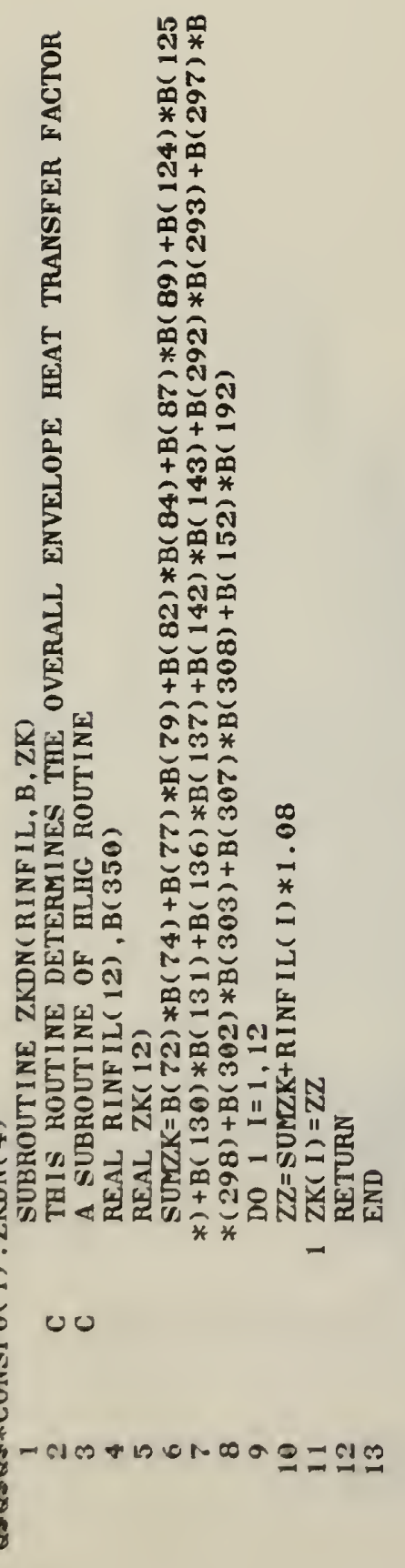




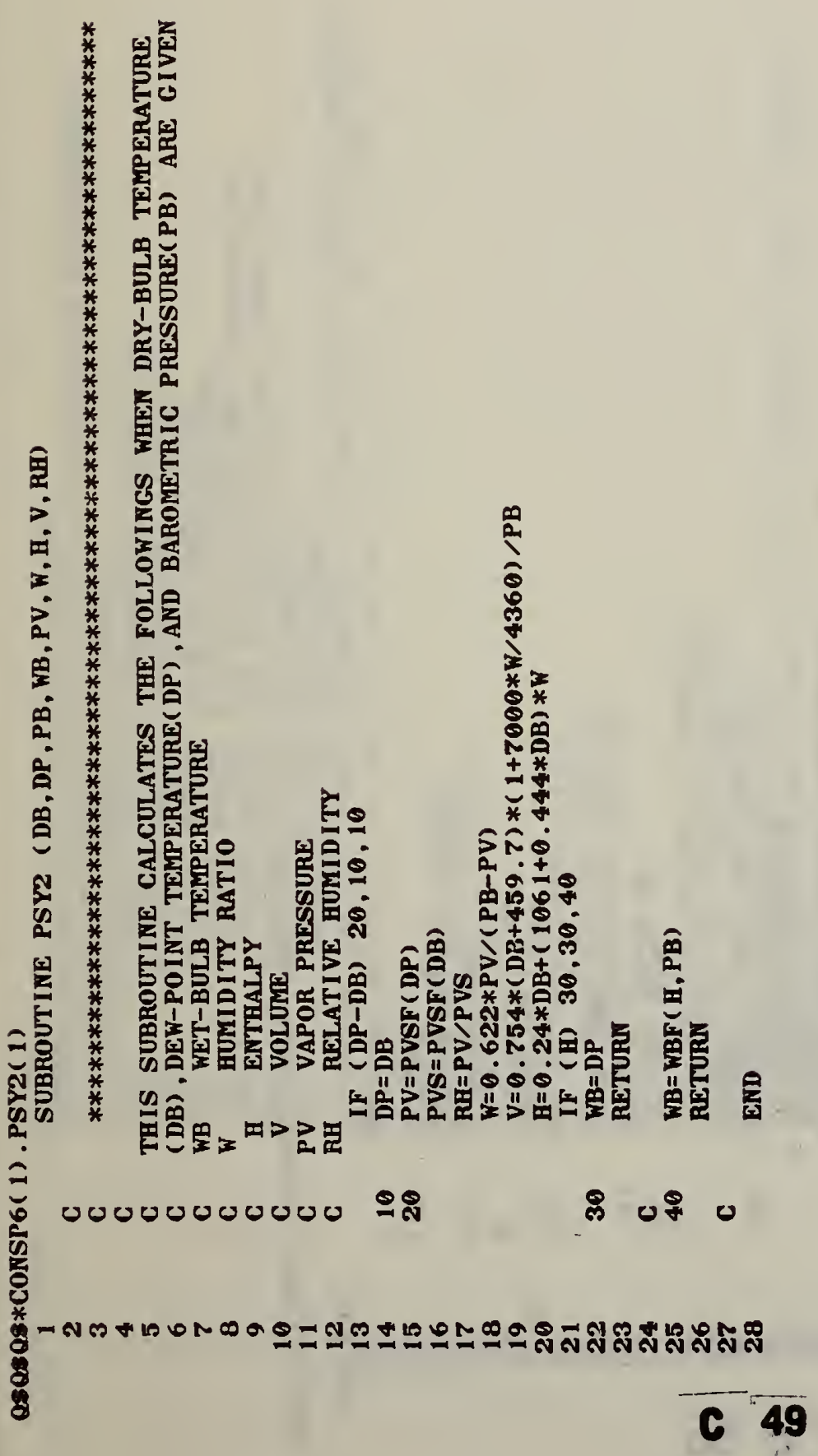




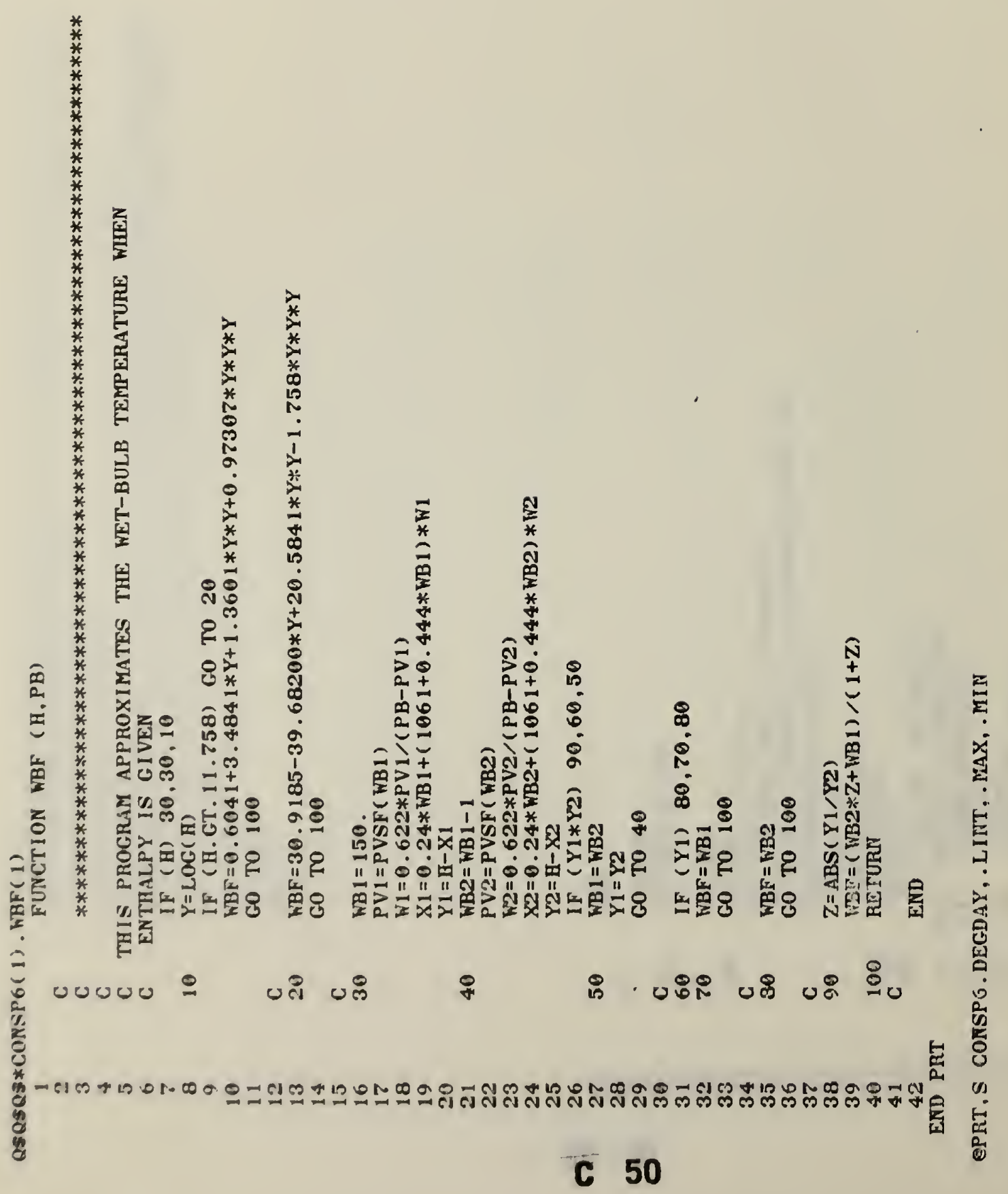




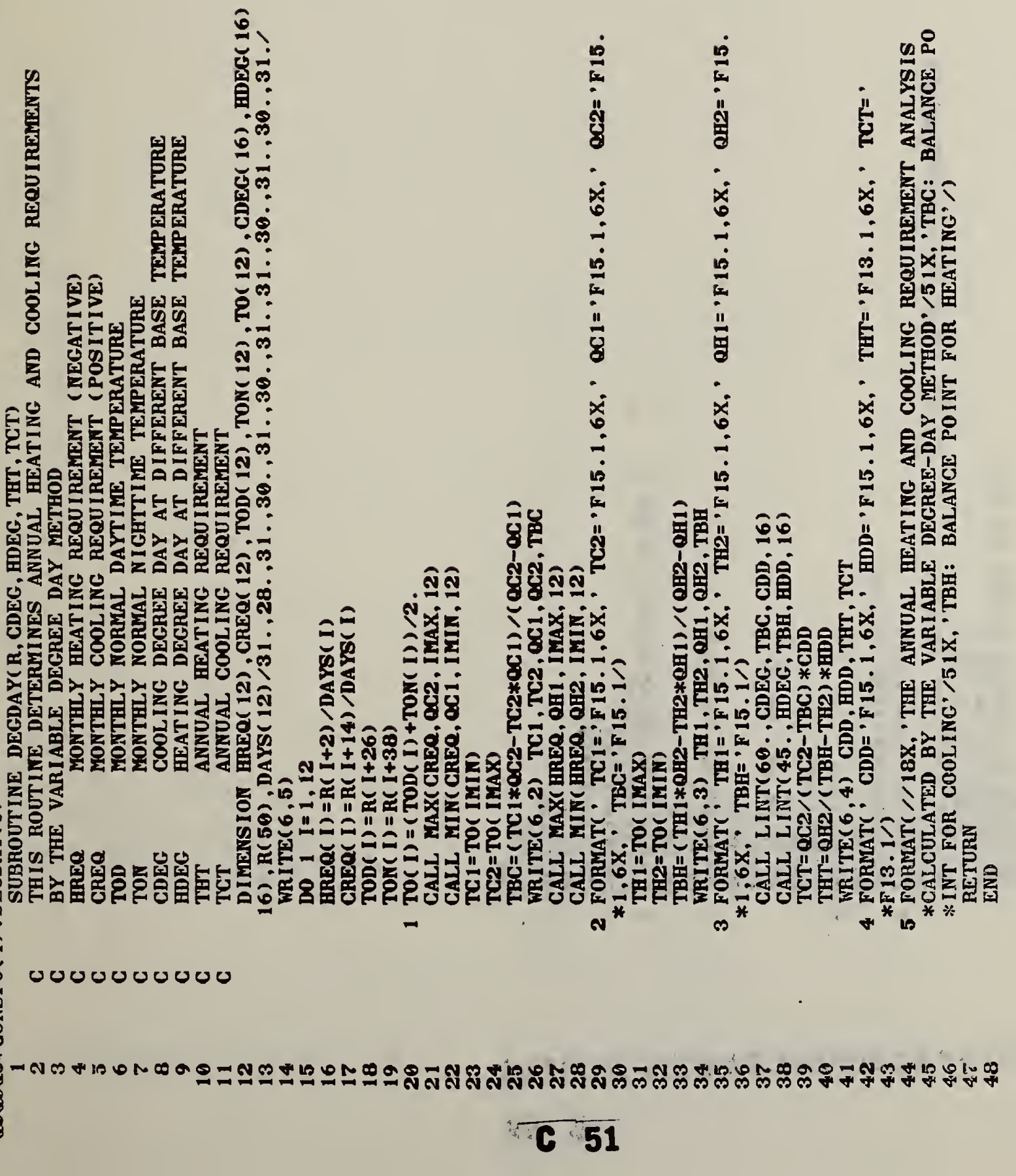




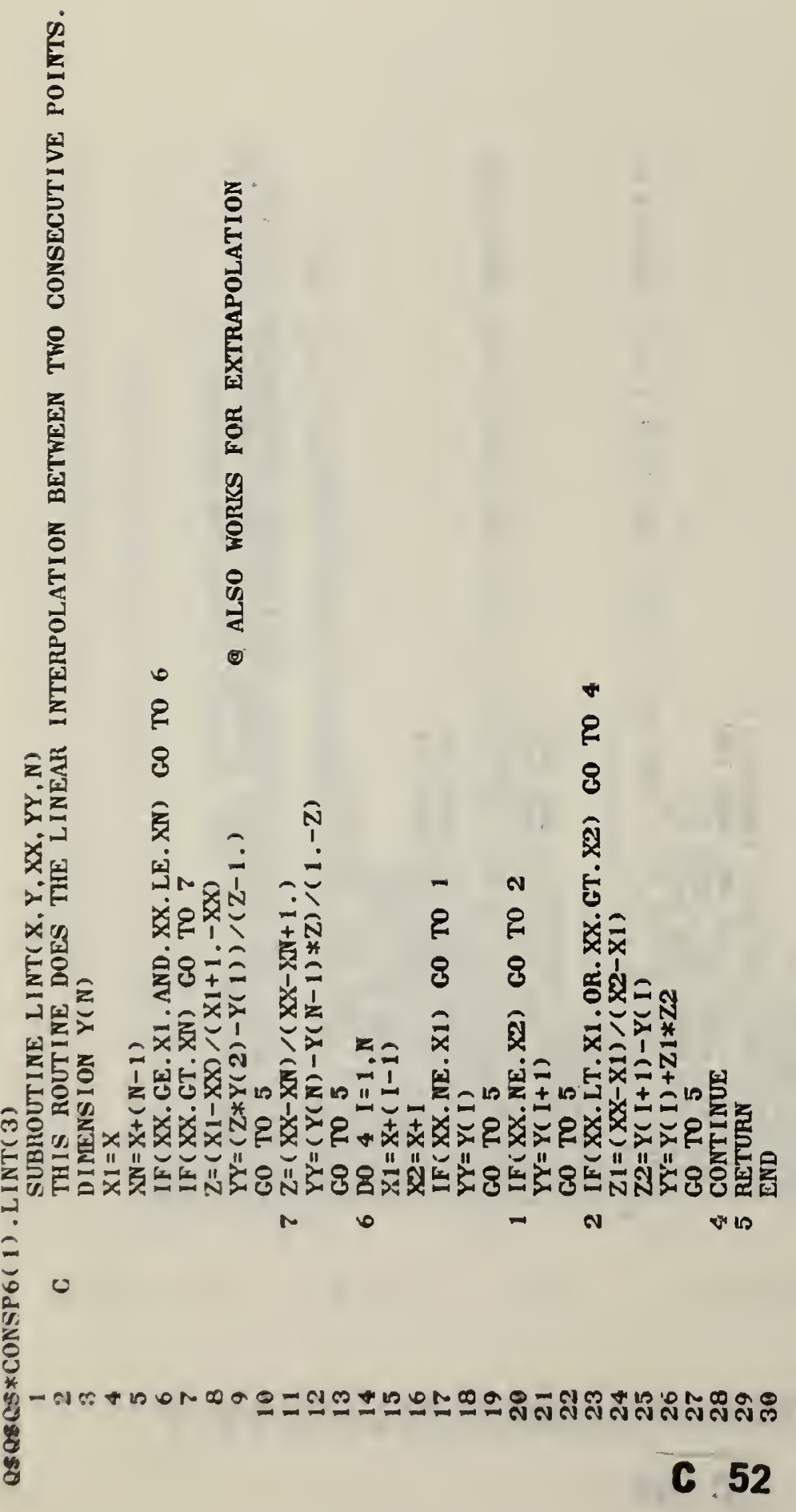


窇

量

罗

在

茼

4 is 8

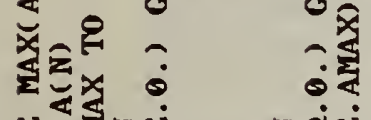

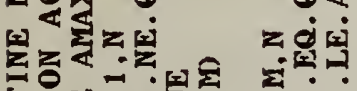

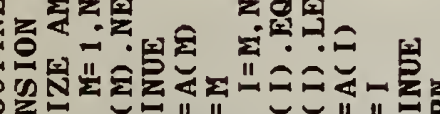

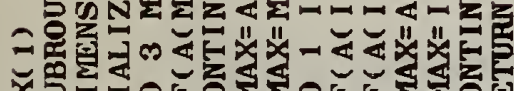

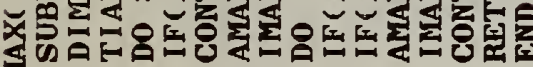

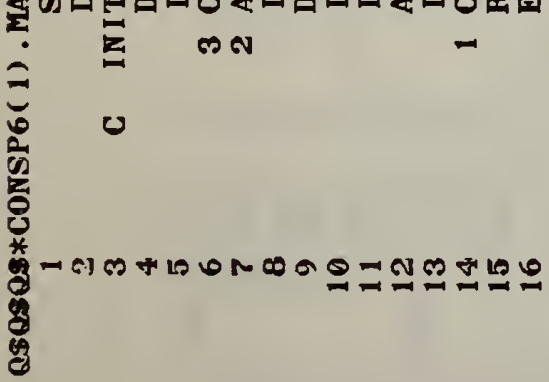


葛

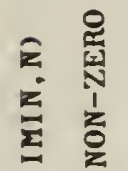

कิ

完告

$-\overline{0}$

\& 8

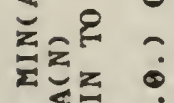

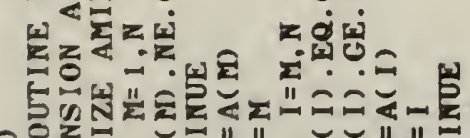

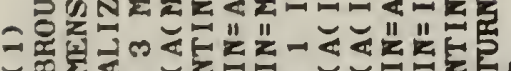

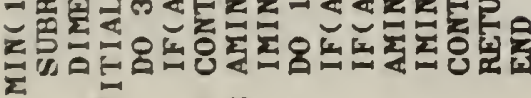

Z
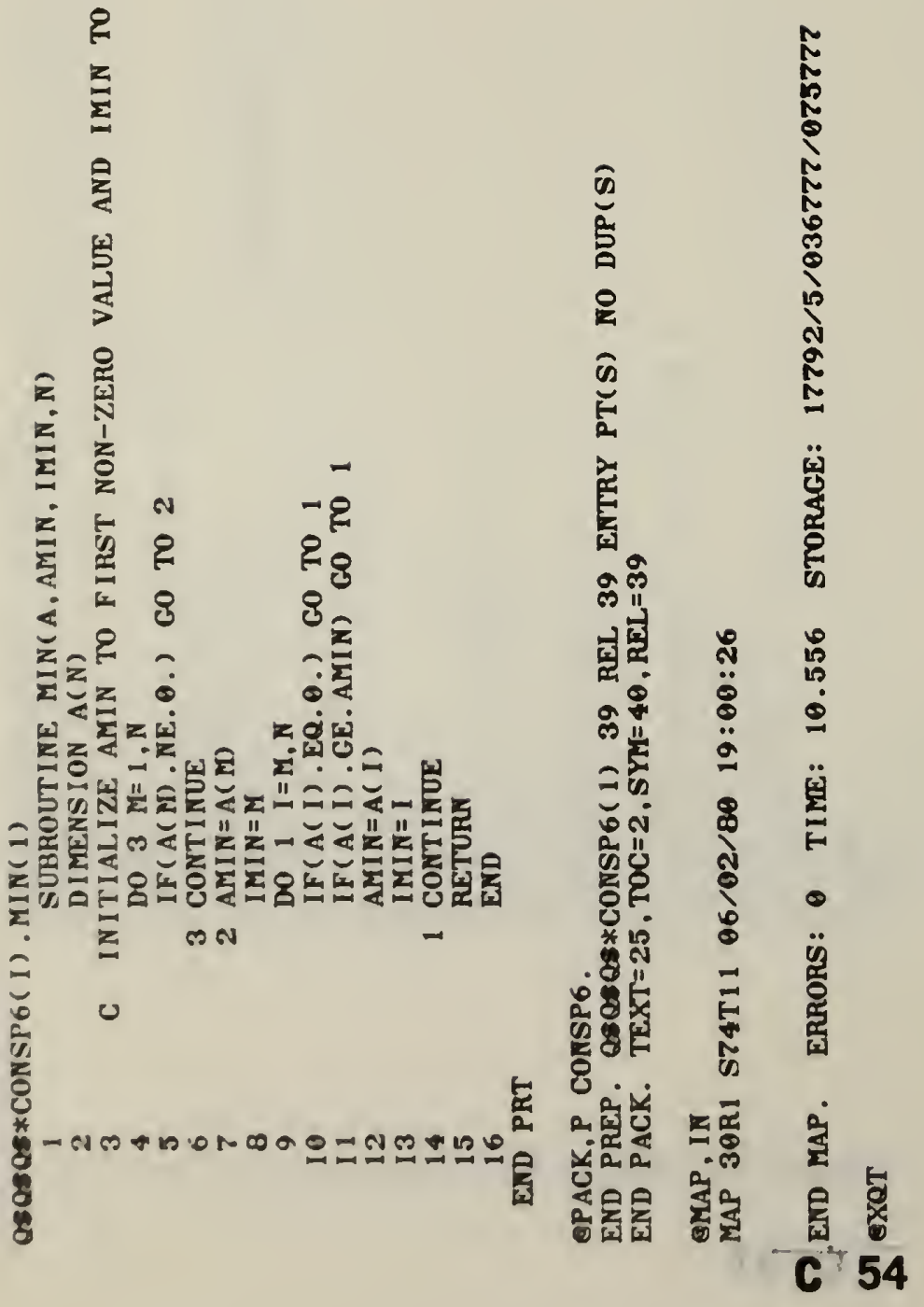


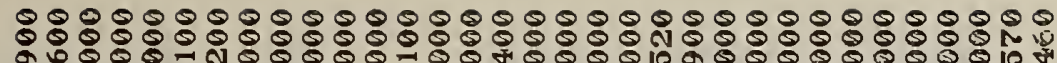

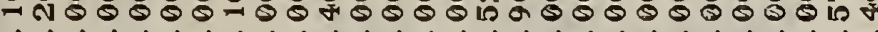
N 00000000000 iे 000000000 की 00000000

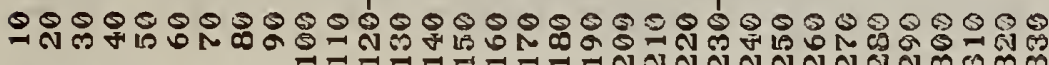

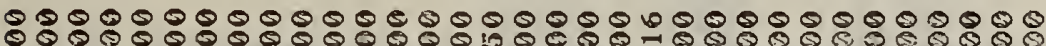
สสษ \& Niginம N

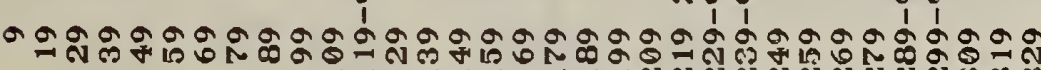

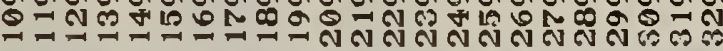

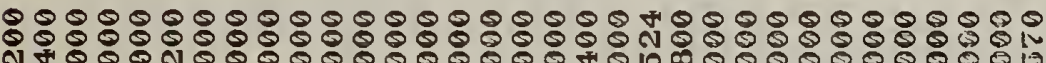
H. 눙요

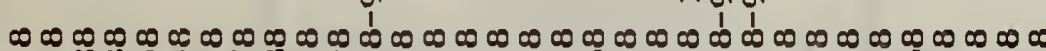
- ล

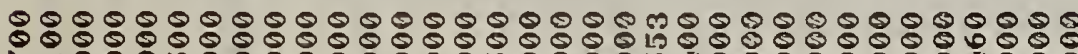

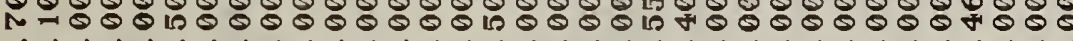

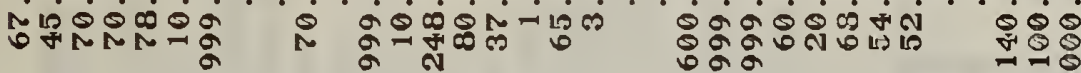
i $i \quad$ i

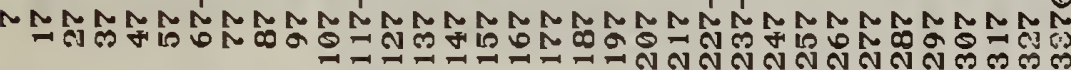

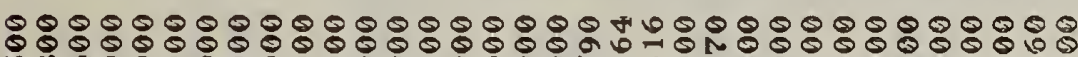
й L

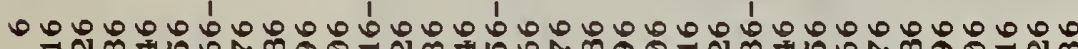
政

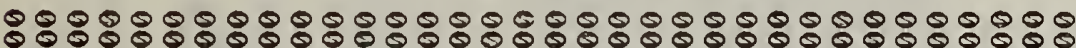

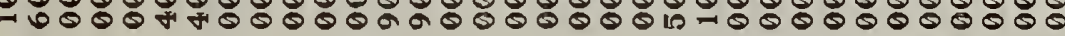

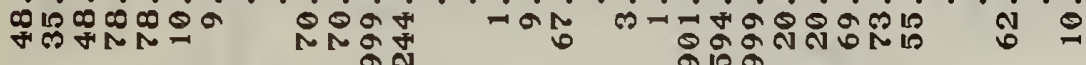

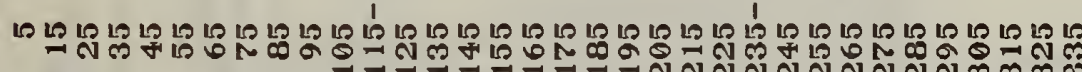

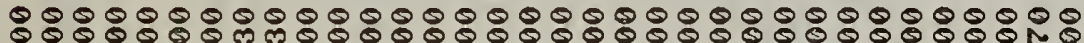

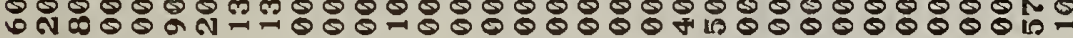

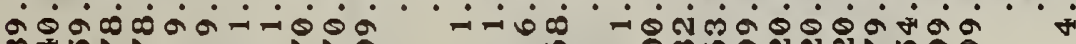
intin 숑 बे เด i नू. कू

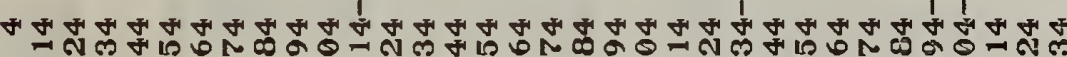

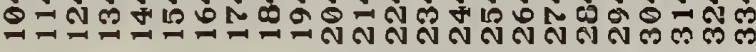

00000000000110000000000000000 hido

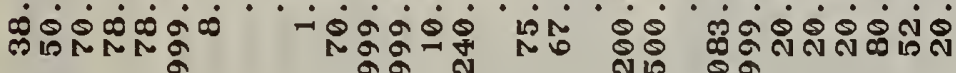

$$
\text { ล NGू̆ }
$$

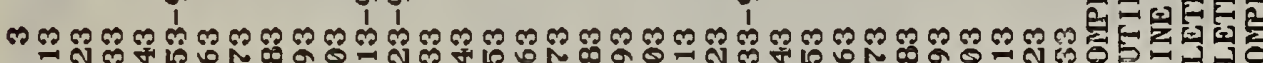
-

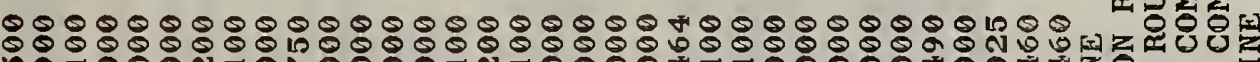
LA

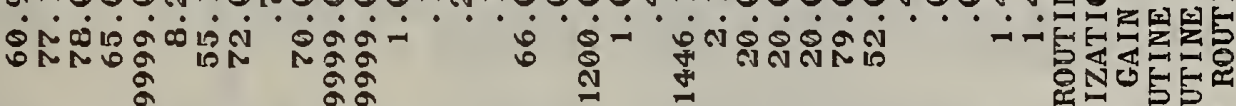
ก N

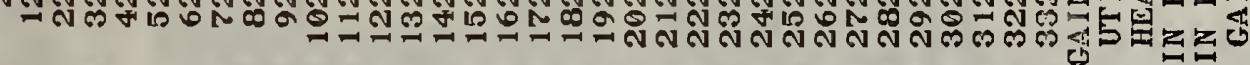

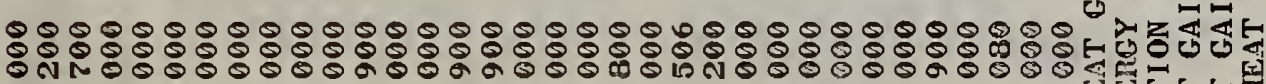
\%n.

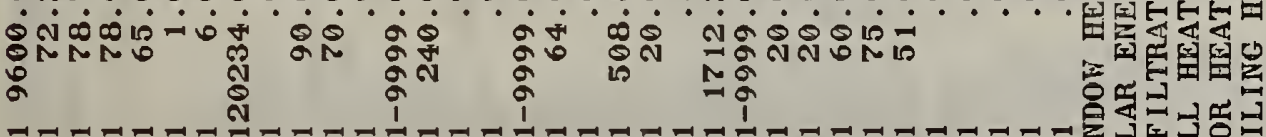

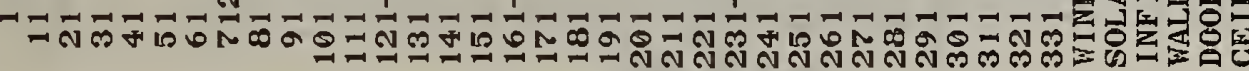

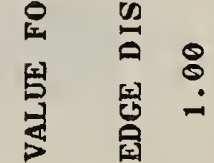

톨

㦼些

古

电先

ड़

를

里聍

$$
\text { অ. }
$$$$
\text { . }
$$$$
\begin{aligned}
& + \\
& \vdots \\
& \vdots \\
& \vdots \\
& \vdots \\
& \vdots \\
& \vdots \\
& +
\end{aligned}
$$$$
\text { 急 } 8
$$$$
\text { 옹 }
$$

耐

$$
\text { 口 }
$$

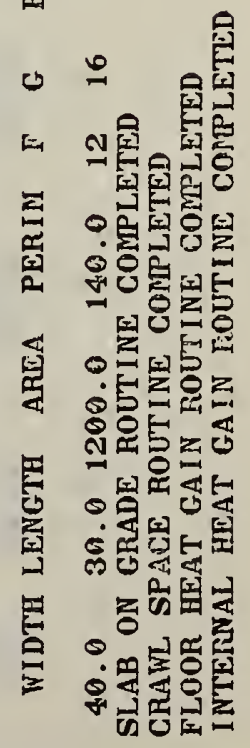




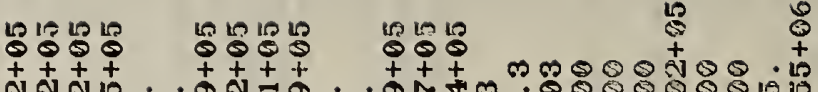

$=3$

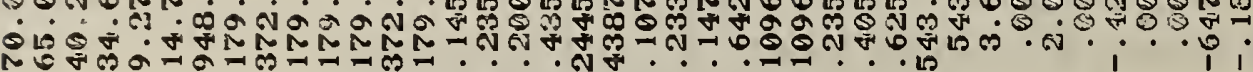
NA

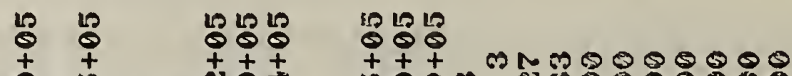

z 8ㅇำ

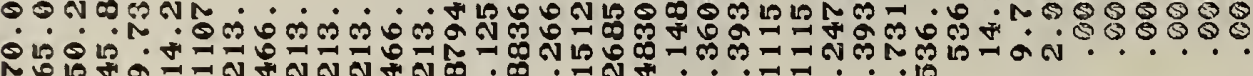

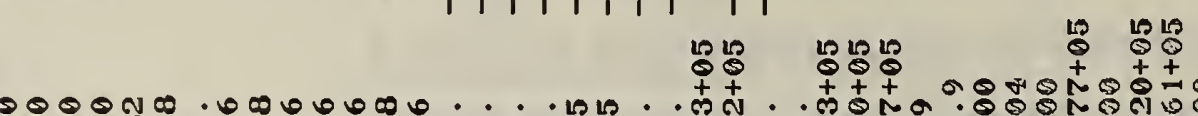

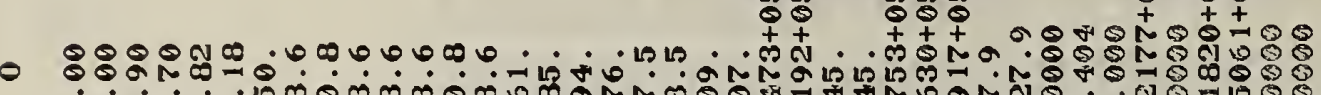

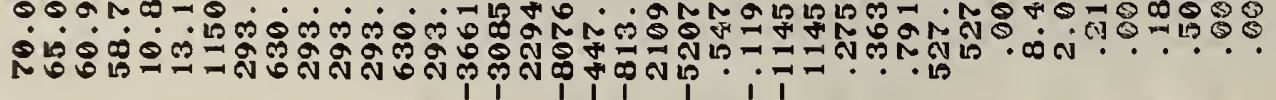

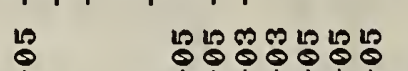

19

t+1

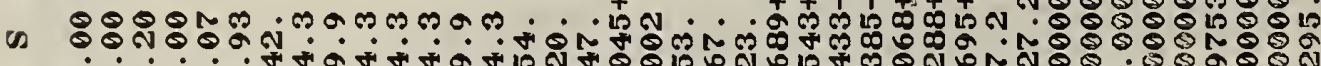
象N

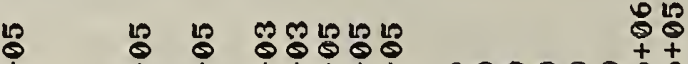

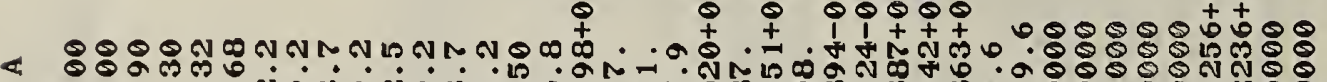

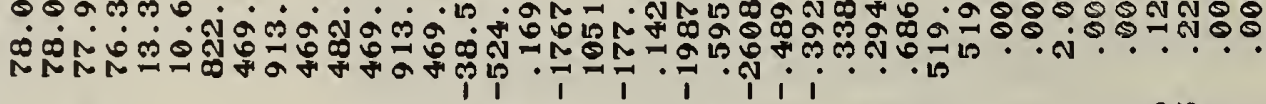

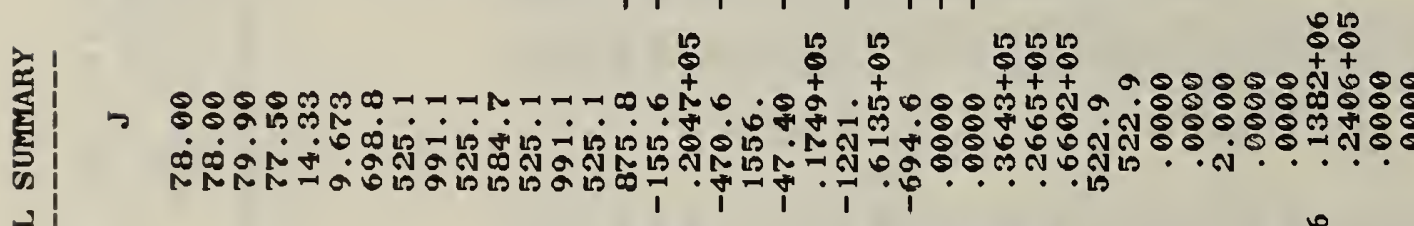

농

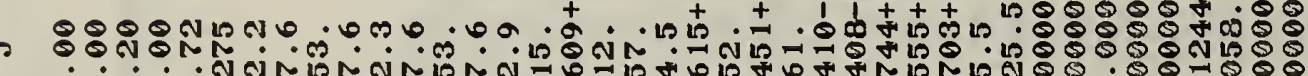

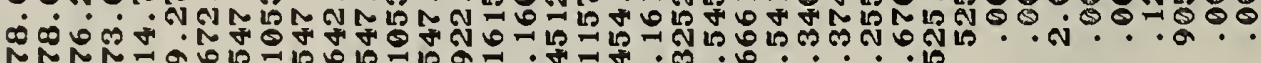

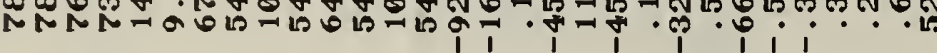

4h

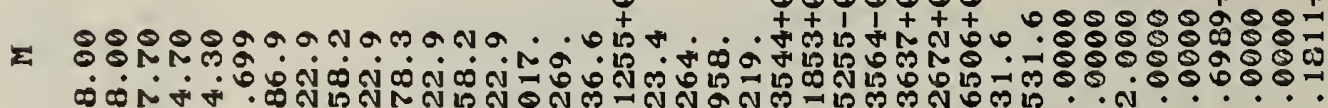
NNG

L

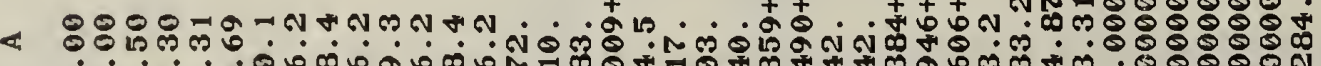

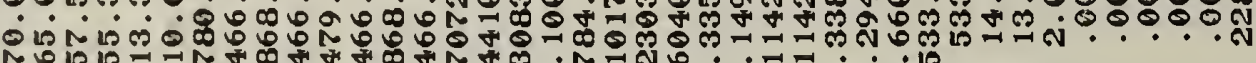

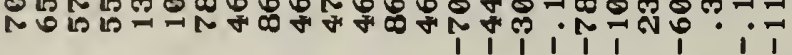

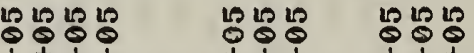

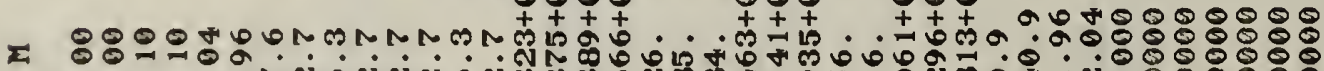
Q

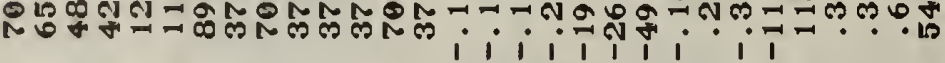

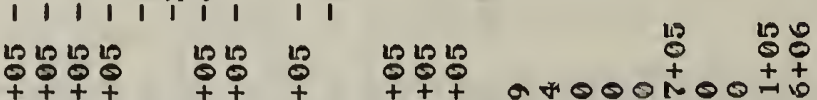

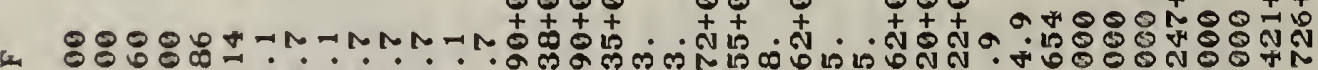

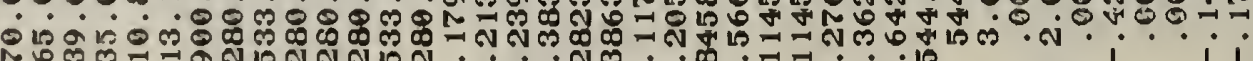

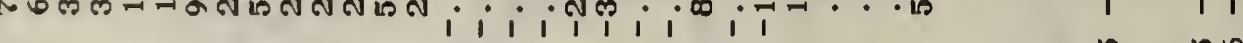

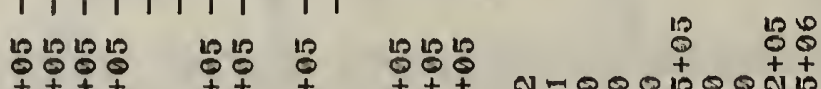

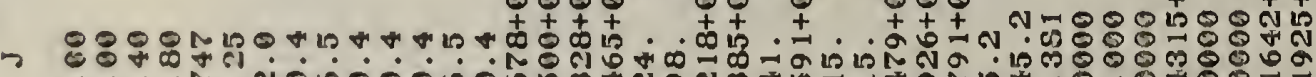
$\dot{0} \omega \dot{1}^{n}$. B.

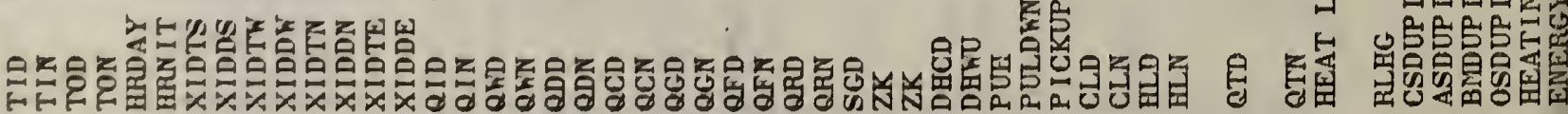

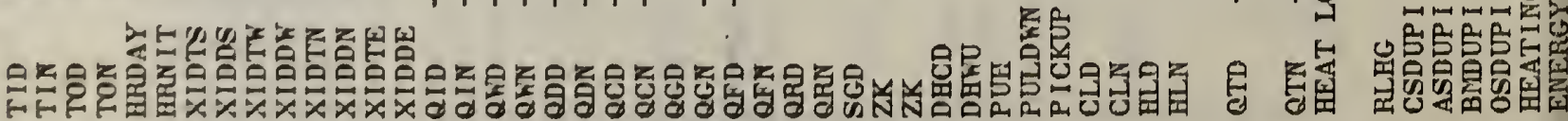




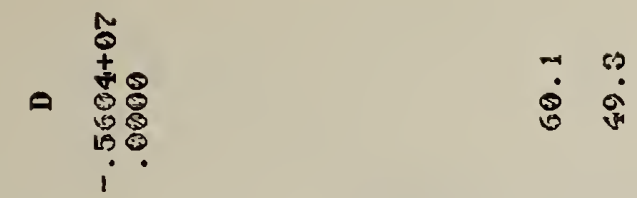

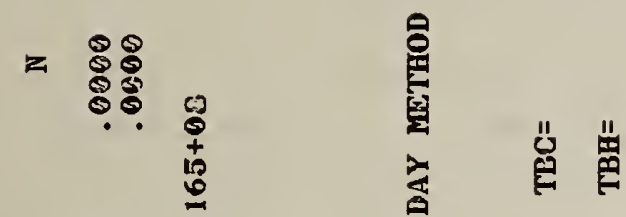

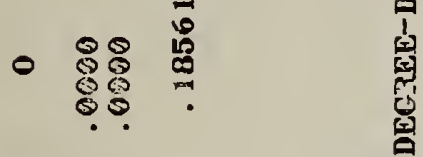

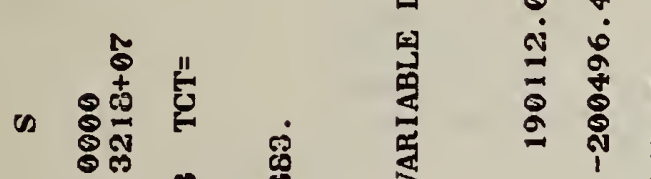

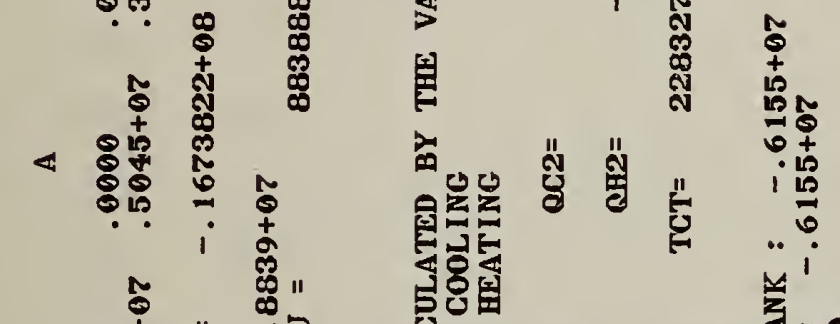

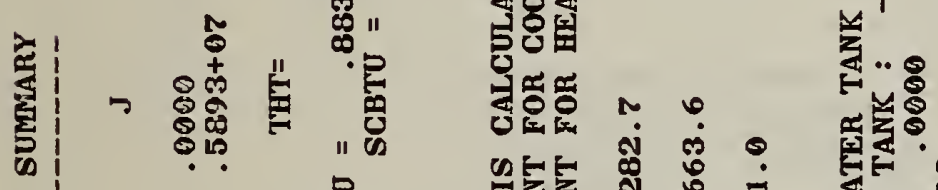

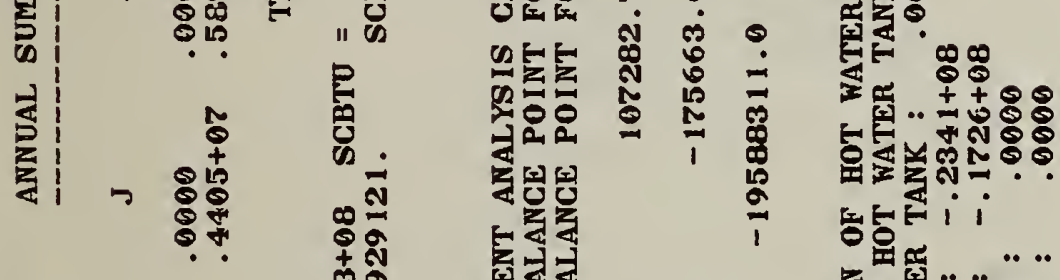

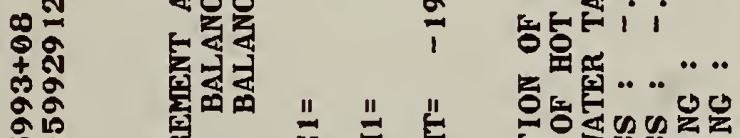

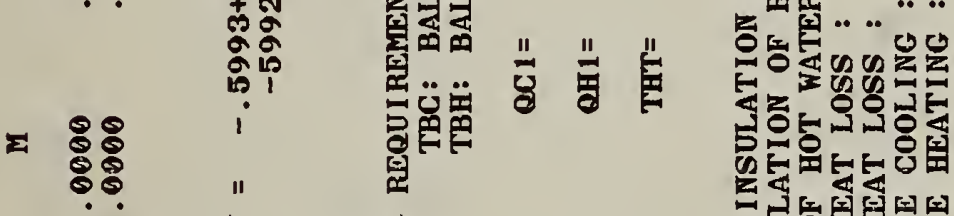

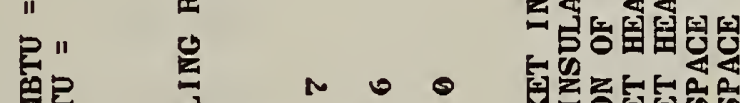

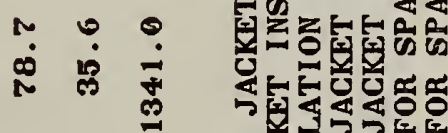

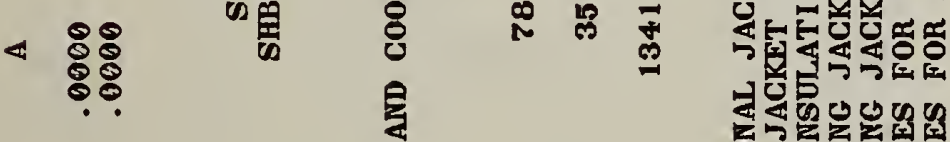

$$
\begin{aligned}
& \text { 은 } \\
& \text { = } 8.8 \text {. }
\end{aligned}
$$

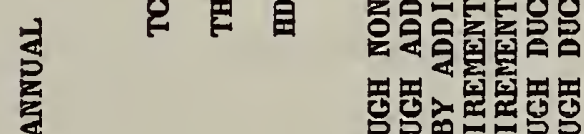

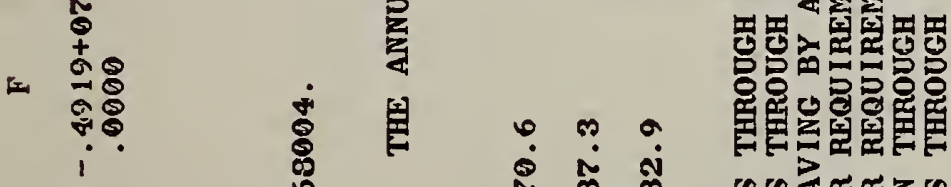

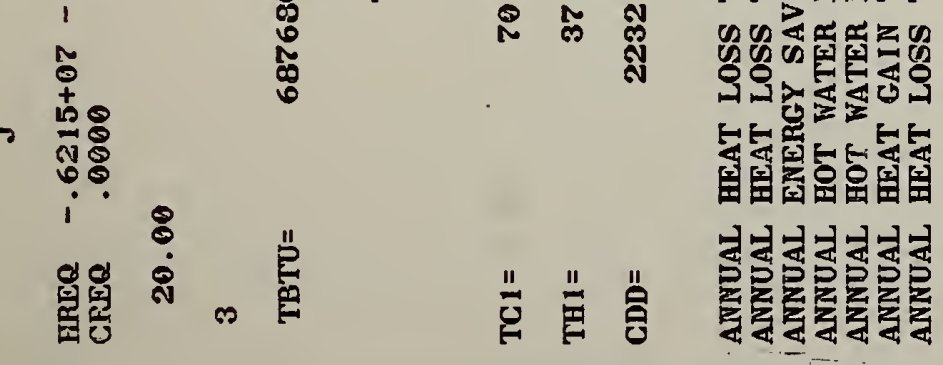

$$
\begin{aligned}
& \text { C } 57
\end{aligned}
$$





\begin{tabular}{|c|c|c|c|c|c|}
\hline Number* & Variable & Type & Comments & Units & Meaning \\
\hline$B(1)$ & V & $\mathrm{F}$ & & $f t^{3}$ & $\begin{array}{l}\text { Volume }(\mathrm{L} * \mathrm{~W} * \mathrm{H}) \text { of Heated Living } \\
\text { Area }\end{array}$ \\
\hline$B(2)$ & ACRM & $\mathrm{F}$ & $\begin{array}{l}\text { Tight }=.5 \\
\text { Average }=1.0 \\
\text { Leaky }=1.5 \\
\text { Very Leaky }=2.0\end{array}$ & ACihr & Standard Air Leakage Data \\
\hline$B(3-14)$ & $\operatorname{TOD}(\mathrm{X})$ & $F(12)$ & & $\operatorname{deg} F$ & Daytime Outdoor Temperature (Month) \\
\hline$B(15-26)$ & $\operatorname{TOT}(\mathrm{X})$ & $F(12)$ & & $\operatorname{deg} F$ & Daily Temperature (Month) \\
\hline$B(27-38)$ & $\operatorname{TID}(\mathrm{X})$ & $F(12)$ & 1 & $\operatorname{deg} F$ & Daytime Indoor Temperature (Month) \\
\hline$B(39-50)$ & $\operatorname{TIN}(\mathrm{X})$ & $F(12)$ & & $\operatorname{deg} F$ & Nighttime Indoor Temperat ure (Month) \\
\hline$B(51)$ & IACNV & I & $\begin{array}{l}\text { 0-Never open windows } \\
1 \text {-0pen windows in summer } \\
\text { when temp. < thermostat } \\
\text { setting } \\
\text { Default }=0\end{array}$ & & \\
\hline$B(52)$ & $\mathrm{X} 1$ & $\mathrm{~F}$ & Unused & & \\
\hline$B(53)$ & $\mathrm{X} 2$ & $\mathrm{~F}$ & Unused & . & \\
\hline$B(54-65)$ & WS $(X)$ & $F(12)$ & & $\mathrm{mph}$ & Wind Speed \\
\hline$B(66)$ & $\times 3$ & $\mathrm{~F}$ & Unused & & \\
\hline$B(67)$ & $\mathrm{X} 4$ & $\mathrm{~F}$ & Unused & & \\
\hline $\begin{array}{l}B(68) \\
B(69)\end{array}$ & ORT1 & $\mathrm{F}$ & $0.0-359.0$ & $\operatorname{deg}$ & $\begin{array}{l}\text { Orientation from south of window/ } \\
\text { wall/door No. } 1 \\
\text { Latitude (North) }\end{array}$ \\
\hline
\end{tabular}

* Number shows position of element at data statement in main program. 


\begin{tabular}{|c|c|c|c|c|c|}
\hline Number & Variable & Type & Comments & Units & Meaning \\
\hline$B(70)$ & RHO & $\mathrm{F}$ & $\begin{array}{l}0.2=\text { Dark } \\
0.4=\text { Medium } \\
0.6=\text { Light }\end{array}$ & --- & Ground Surface Reflectance \\
\hline$B(71)$ & $\mathrm{ZIP}$ & I & & & Zip Code \\
\hline$B(72)$ & $\mathrm{AGl}$ & $\mathbf{F}$ & & $\mathrm{ft}^{2}$ & Window 1 Area \\
\hline$B(73)$ & $\mathrm{sCl}$ & F & $\begin{array}{l}\text { Default }=0.55 \text { If } \\
\text { Shades Else } 0\end{array}$ & --- & Window 1 Shading Coefficient \\
\hline$B(74)$ & UG1 & F & $\begin{array}{l}1.13=\text { Single Glaze } \\
0.55=\text { Double Glaze } \\
\text { Default }=1.13\end{array}$ & Btuh $^{*}$ & Window $1 \mathrm{U}$ Value \\
\hline$B(75)$ & SHADW1 & F & $\begin{array}{l}1.0=\text { All Shadow } \\
0.5=\text { Part Shadow } \\
0.0=\text { No Shadow } \\
\text { Default }=0.0\end{array}$ & -- & Window 1 Shadow \\
\hline$B(76)$ & ORT2 & F & $0.0-359.0$ & $\operatorname{deg}$ & $\begin{array}{l}\text { Orientation from South of Window/ } \\
\text { Wall/Door No. } 2\end{array}$ \\
\hline$B(77)$ & $\mathrm{AG} 2$ & F & & $\mathrm{ft} \mathrm{t}^{2}$ & Window 2 Area \\
\hline$B(78)$ & $\mathrm{sc2}$ & F & $\begin{array}{l}\text { Default }=0.55 \text { if } \\
\text { Shades Else } 0\end{array}$ & --- & Window 2 shading coefficient \\
\hline$B(79)$ & UG2 & $\mathbf{F}$ & $\begin{array}{l}1.13=\text { Single Glaze } \\
0.55=\text { Double Glaze } \\
\text { Default }=1.13\end{array}$ & Btuh & Window $2 \mathrm{U}$ value \\
\hline$B(80)$ & SHADW2 & $\mathbf{F}$ & $\begin{array}{l}1.0=\text { All Shadow } \\
0.5=\text { Part Shadow } \\
0.0=\text { No Shadow } \\
\text { Default }=0.0\end{array}$ & --- & Window 2 Shadow \\
\hline$B(81)$ & ORT3 & $\mathrm{F}$ & $0.0-359.0$ & $\operatorname{deg}$ & $\begin{array}{l}\text { Orientation from South of Window/ } \\
\text { Wall/Door No. } 3\end{array}$ \\
\hline$B(82)$ & AG3 & $\mathrm{F}$ & & $\mathrm{ft}^{2}$ & Window 3 Area \\
\hline$B(83)$ & sc3 & F & $\begin{array}{l}\text { Default }=0.55 \text { If } \\
\text { Shades Else } 0\end{array}$ & -- & Window 3 Shading Coefficient \\
\hline$B(84)$ & UGE & $\mathbf{F}$ & $\begin{array}{l}1.13=\text { Single Glaze } \\
0.55=\text { Double Glaze } \\
\text { Default }=1.13\end{array}$ & Btuh & Window $3 \mathrm{U}$ Value \\
\hline
\end{tabular}

* Btuh $=$ Btu/hr ft ${ }^{2} \mathrm{~F}$

all the $U$ values hereafter will be expressed in this unit 


\begin{tabular}{|c|c|c|c|c|c|}
\hline Number & Variable & Ty pe & Comments & Units & Meaning \\
\hline$B(85)$ & SHADW3 & $\mathrm{F}$ & $\begin{array}{l}1.0=\text { All Shadow } \\
0.5=\text { Part Shadow } \\
0.0=\text { No Shadow } \\
\text { Default }=0.0\end{array}$ & $-\infty$ & Window 3 Shadow \\
\hline$B(86)$ & ORT4 & $F$ & $0.0-359.0$ & $\operatorname{deg}$ & $\begin{array}{l}\text { Orientation from South of Window/ } \\
\text { Wall/Door No. } 4\end{array}$ \\
\hline $\mathrm{B}(87)$ & AG4 & $F$ & $0.0-359.0$ & $f t^{2}$ & Window 4 Area \\
\hline $\mathrm{B}(88)$ & $\mathrm{sC} 4$ & $\mathrm{~F}$ & $\begin{array}{l}\text { Default }=0.55 \text { If } \\
\text { Shades Else } 0\end{array}$ & --- & Window 4 Shading Coefficient \\
\hline$B(89)$ & UG4 & $\mathrm{F}$ & $\begin{array}{l}1.13=\text { Single Glaze } \\
0.55=\text { Double Glaze } \\
\text { Default }=1.13\end{array}$ & Btuh & Window $4 \mathrm{U}$ Value \\
\hline$B(90)$ & SHDW4 & $\mathrm{F}$ & $\begin{array}{l}1.0=\text { All Shadow } \\
0.5=\text { Part Shadow } \\
0.0=\text { No Shadow } \\
\text { Default }=0.0\end{array}$ & --- & Window 4 Shadow \\
\hline$B(91)$ & WT ILTI & $\mathrm{F}$ & Default $=50.0$ & $\begin{array}{l}\text { deg from } \\
\text { horiz }\end{array}$ & Solar Collector Tilt Angle \\
\hline$B(92)$ & SA & $\mathrm{F}$ & $\begin{array}{l}\text { High Performance }=0.8 \\
\text { Medium Performance }=0.75 \\
\text { Low Performance }=0.7 \\
\text { Default }=0.7\end{array}$ & $-\cdots$ & $\begin{array}{l}\text { Solar Collector Efficiency (Y Axis) } \\
\text { (Absorption Factor From Glass) }\end{array}$ \\
\hline$B(93)$ & $\mathrm{SB}$ & $\mathrm{F}$ & $\begin{array}{l}\text { High Performance }=1.2 \\
\text { Medium Performance }=1.0 \\
\text { Low Performance }=0.8 \\
\text { Default }=0.8\end{array}$ & -- & $\begin{array}{l}\text { Solar Collector Efficiency (X Axis) } \\
\text { (Water Temp - Outdoor Temp)/Solar } \\
\text { Radiation }\end{array}$ \\
\hline$B(94-105)$ & $\mathrm{TE}(\mathrm{X})$ & $F(12)$ & Default $=70.0$ & $\operatorname{deg} F$ & $\begin{array}{l}\text { Inlet Fluid Temperature to Solar } \\
\text { Collector (Ionth) }\end{array}$ \\
\hline$B(106)$ & SUF & F & Default $=1.0$ & -- & Sollar Collector Utilization \\
\hline $\mathrm{B}(107)$ & AS & $\mathrm{F}$ & Default $=0.0$ & $\mathrm{ft}^{2}$ & $\begin{array}{l}\text { Solar Collector Area } \\
=0 \text { to Signal No Sollar Collector }\end{array}$ \\
\hline$B(108)$ & $\mathrm{X} 5$ & F & Default $=1.0$ & ft & $\begin{array}{l}\text { Roof overhang projection over } \\
\text { wa } 111\end{array}$ \\
\hline$B(109)$ & $\mathrm{X} 6$ & $\mathrm{~F}$ & Default $=10.0$ & ft & Height of wall 1 \\
\hline$B(110)$ & WALL13 & F & $\begin{array}{l}\text { Much }=1.0 \\
\text { Part }=0.5 \\
\text { None }=0.0 \\
\text { Default }=0.0\end{array}$ & -- & Wall 1 Shadow Factor \\
\hline
\end{tabular}




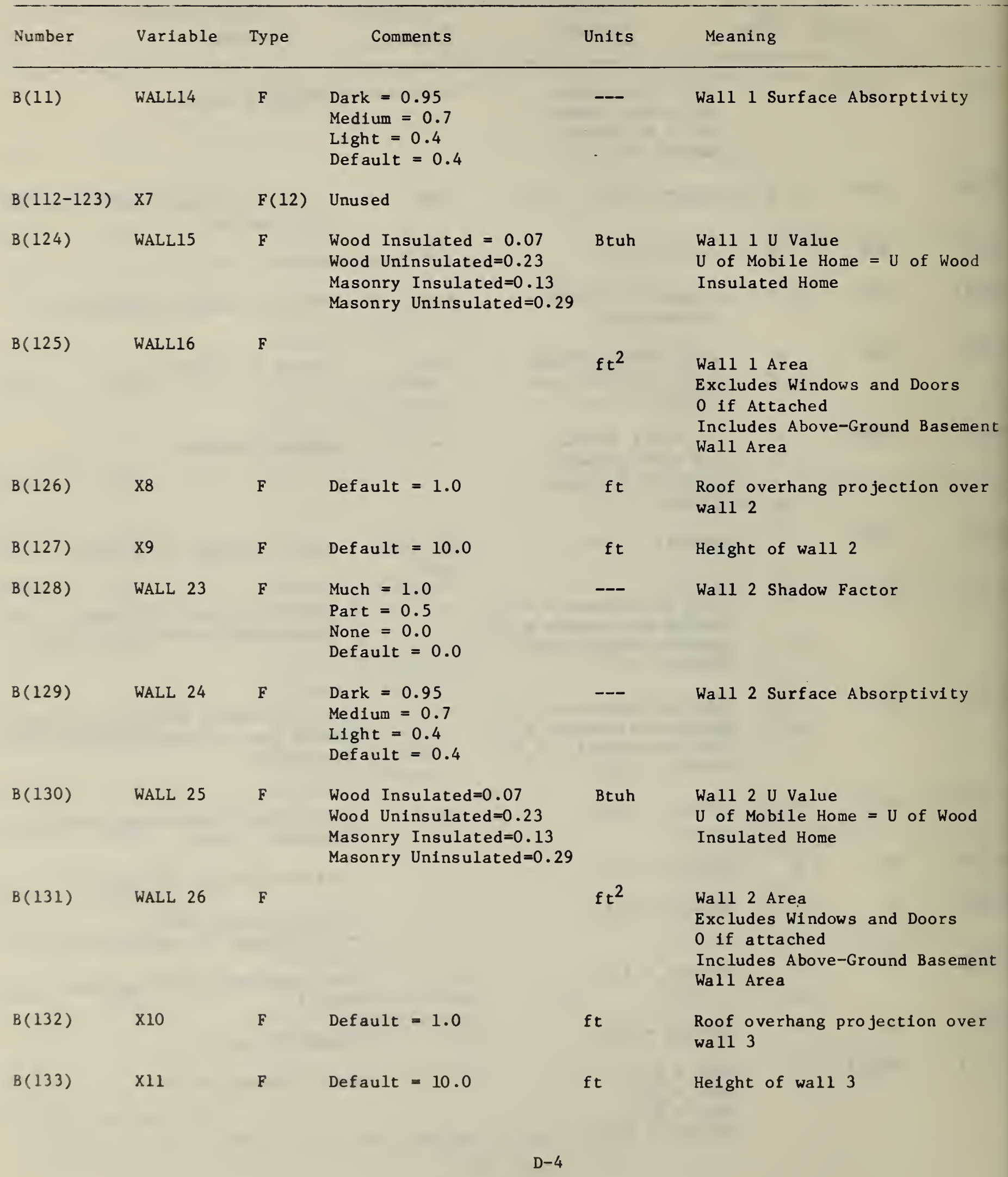




\begin{tabular}{|c|c|c|c|c|c|}
\hline Number & Variable & Type & Comments & Units & Meaning \\
\hline$B(134)$ & WALL 33 & $\mathbf{F}$ & $\begin{array}{l}\text { Much }=1.0 \\
\text { Part }=0.5 \\
\text { None }=0.0 \\
\text { Default }=0.0\end{array}$ & -- & Wal1 3 Shadow Factor \\
\hline$B(135)$ & WALL 34 & $\mathbf{F}$ & $\begin{array}{l}\text { Dark }=0.95 \\
\text { Medium }=0.7 \\
\text { Light }=0.4 \\
\text { Default }=0.4\end{array}$ & -- & Wa11 3 Surface Absorptivity \\
\hline$B(136)$ & WALL 35 & $\mathbf{F}$ & $\begin{array}{l}\text { Wood Insulated }=0.07 \\
\text { Wood Uninsulated }=0.23 \\
\text { Masonry Insulated }=0.13 \\
\text { Masonry Uninsulated }=0.29\end{array}$ & Btuh & $\begin{array}{l}\text { Wall } 3 \text { U Value } \\
U \text { of Mobile Home }=U \text { of Wood } \\
\text { Insulated Home }\end{array}$ \\
\hline B (137) & WALL 36 & $\mathbf{F}$ & & $f t^{2}$ & $\begin{array}{l}\text { Wall } 3 \text { Area } \\
\text { Excludes Windows and Doors } \\
0 \text { if Attached } \\
\text { Includes Above-Ground Basement } \\
\text { Wall Area }\end{array}$ \\
\hline$B(138)$ & $\mathrm{X} 12$ & $\mathbf{F}$ & Default $=1.0$ & ft & $\begin{array}{l}\text { Roof overhang projection over } \\
\text { wall } 4\end{array}$ \\
\hline$B(139)$ & $\mathrm{X} 13$ & $\mathbf{F}$ & Default $=10.0$ & ft & Height of wall 4 \\
\hline$B(140)$ & WALL 43 & $\mathbf{F}$ & $\begin{array}{l}\text { Much }=1.0 \\
\text { Part }=0.5 \\
\text { None }=0.0 \\
\text { Default }=0.0\end{array}$ & $-\cdots$ & Wall 4 Shadow Factor \\
\hline$B(141)$ & WALL 44 & $\mathbf{F}$ & $\begin{array}{l}\text { Dark }=0.95 \\
\text { Medium }=0.7 \\
\text { Light }=0.4 \\
\text { Default }=0.4\end{array}$ & -- & Wall 4 Surface Absorptivity \\
\hline$B(142)$ & WALL 45 & $\mathbf{F}$ & $\begin{array}{l}\text { Wood Insulated }=0.07 \\
\text { Wood uninsulated }=0.23 \\
\text { Masonry Insulated }=0.13 \\
\text { Masonry Uninsulated }=0.29\end{array}$ & Btuh & $\begin{array}{l}\text { Wall } 4 \mathrm{U} \text { Value } \\
\mathrm{U} \text { of Mobile Home }=\mathrm{U} \text { of Wood } \\
\text { Insulated Home }\end{array}$ \\
\hline$B(144)$ & SOGFRC & $\mathbf{F}$ & $\begin{array}{l}0.0-1.0(\text { SUM B }(144-146) \\
=1)\end{array}$ & -- & Fraction of Floor Which is SOG \\
\hline
\end{tabular}

$$
\text { D-5 }
$$




\begin{tabular}{|c|c|c|c|c|c|}
\hline Number & Variable & Type & Comments & Units & Meaning \\
\hline$B(145)$ & CRWFRC & $\mathrm{F}$ & $\begin{array}{l}0.0-1.0(\text { SUN } B(144-146) \\
=1)\end{array}$ & -- & $\begin{array}{l}\text { Fraction of Floor Which is } \\
\text { Crawl Space }\end{array}$ \\
\hline$B(146)$ & BSMFRC & F & $\begin{array}{l}0.0-1.0(\text { SUM } B(144-146) \\
=1)\end{array}$ & -- & $\begin{array}{l}\text { Fraction of Floor Which is } \\
\text { Basement }\end{array}$ \\
\hline$B(147-148)$ & $\mathrm{X} 14$ & $F(2)$ & Unused & & \\
\hline$B(149)$ & $\begin{array}{l}\text { ROOF } 4 \\
\text { (ANATT) }\end{array}$ & $\mathrm{F}$ & Default $=0.0$ & $\mathrm{ft}^{2}$ & $\begin{array}{l}\text { Non-Attic Roof Area } \\
(\text { AFLOOR - ATFLR) }\end{array}$ \\
\hline$B(150)$ & ROOF1 & F & $\begin{array}{l}\text { Default }=0.0 \\
1.0=\text { Al } 1 \text { Shadow } \\
0.5=\text { Part Shadow } \\
0.0=\text { No Shadow }\end{array}$ & --- & Roof Shadow Factor \\
\hline$B(151)$ & ROOF 2 & F & $\begin{array}{l}\text { Default }=0.9 \\
\text { Dark }=0.95 \\
\text { Medium }=0.7 \\
\text { Light }=0.4\end{array}$ & --- & Roof Absorptivity \\
\hline$B(152)$ & ROOF 3 & F & $\begin{array}{l}\text { Default }=0.2 \\
0.55 \text { With Vented or } \\
\text { No Attic } \\
0.2 \text { With Unvented Attic }\end{array}$ & Btuh & Roof U Value \\
\hline$B(153)$ & AEWH & F & Default $=4.0$ & ft & Attic End Wall Height \\
\hline$B(154)$ & SOLHW & I & $\begin{aligned} 0= & \text { Not Used for Hot } \\
& \text { Water } \\
1= & \text { Is Used }\end{aligned}$ & $\cdots$ & $\begin{array}{l}\text { Use of Solar Collector for Hot } \\
\text { Water Heating }\end{array}$ \\
\hline$B(155)$ & SOLSH & I & $\begin{aligned} 0= & \text { Not Used for llot } \\
& \text { Heating } \\
1= & \text { Is Used }\end{aligned}$ & -- & $\begin{array}{l}\text { Use of Solar Collector For } \\
\text { Space Heating }\end{array}$ \\
\hline$B(156)$ & $\times 23$ & I & Unused & 1 & \\
\hline$B(157)$ & AW & $\mathrm{F}$ & 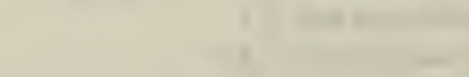 & $\mathrm{ft}^{2}$ & Attic End Wall Area \\
\hline$B(158)$ & ACAT & F & $\begin{aligned} & 20.0= \text { Attic Fan } \\
& 6.0= \text { Soffit Vent and } \\
& \text { Ridge Vent } \\
& 3.0= \text { Cable Vent } \\
& 0.0=\text { No vent } \\
& \text { Default }=3.0\end{aligned}$ & $\mathrm{AC} / \mathrm{hr}$ & Air Change per Hour \\
\hline $\mathrm{B}(159)$ & UCEIL & F & Default $=0.1$ & Btuh & $\begin{array}{l}\text { Celling U Value - Only when } \\
\text { There is an Attic }\end{array}$ \\
\hline
\end{tabular}




\begin{tabular}{|c|c|c|c|c|c|}
\hline Number & Variable & Type & Comments & Units & Meaning \\
\hline$B(160)$ & AEW5 & $\mathbf{F}$ & $\begin{array}{l}\text { Default }=0.25 \\
\text { Same as Wall U B(124) }\end{array}$ & Bt uh & Attic End Wall U Value \\
\hline$B(161)$ & $\mathrm{X} 15$ & $\mathbf{F}$ & Unused & 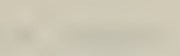 & 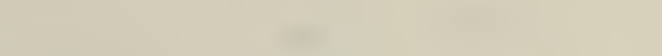 \\
\hline$B(162)$ & UFLRI & $\mathbf{F}$ & Default $=0.30$ & Btuh & $\begin{array}{l}\text { Floor U Value (Floor Above } \\
\text { Basement) }\end{array}$ \\
\hline$B(163)$ & HWT & $\mathbf{F}$ & Default $=75.0$ & gal/day & Hot Water Usage \\
\hline$B(164)$ & NSTART & I & $1-12$ & --- & First Month of Cooling \\
\hline$B(165)$ & NLAST & I & $1-12$ & -- & Last Month of Cooling Season \\
\hline$B(166)$ & INDEXES & I & $\begin{array}{l}\text { 0-Attic is Temp Controlled } \\
\text { 1-Attic Not Temp Controlled } \\
=1 \text { If There is an Attic } \\
\text { Else } 0\end{array}$ & -- & Attic Temperature Control Index \\
\hline$B(167)$ & INDEXC & I & $\begin{array}{l}0 \text { - Basement Heated } \\
1 \text { - Basement Unheated }\end{array}$ & --- & Basement Temperature Control Index \\
\hline$B(168)$ & ZL & $\mathbf{F}$ & & ft & Exposed Perimeter Length of SOG \\
\hline$B(169-180)$ & $\operatorname{TG}(\mathrm{X})$ & $F(12)$ & & $\operatorname{deg} F$ & Ground Temperature (Month) \\
\hline$B(181)$ & ACCS & $\mathbf{F}$ & $\begin{array}{l}0.0=\text { Unvented } \\
3.0=\text { Vented }\end{array}$ & $\begin{array}{r}\mathrm{AC} / \mathrm{hr} \\
\cdots\end{array}$ & Crawl Space Air Change/Hour \\
\hline$B(182)$ & UFLR2 & $\mathbf{F}$ & Default $=0.30$ & Btuh & $\begin{array}{l}\text { Crawl Space Floor U Value (Floor } \\
\text { Above Crawl Space) }\end{array}$ \\
\hline$B(183)$ & UCLW & $F$ & Default $=0.25$ & Btuh & Crawl Space Wall U Value \\
\hline$B(184)$ & $\mathrm{HCL}$ & $\mathbf{F}$ & & $\mathrm{ft}$ & Crawl Space Height \\
\hline$B(185)$ & AWCL & $\boldsymbol{F}$ & & $\mathrm{ft}^{2}$ & Craw1 Space Wall Area \\
\hline$B(186)$ & NPD & I & Default $=3$ & -- & Daytime Occupancy \\
\hline$B(187)$ & NPN & I & Default $=3$ & --- & Nightime Occupancy \\
\hline$B(188)$ & WTD & $\mathbf{F}$ & Default $=0.097 * \mathrm{ft}^{2}$ & watt & Average Daytime Lighting \\
\hline$B(189)$ & WTN & F & Default $=0.217 * \mathrm{ft}^{2}$ & watt & Average Nighttime Lighting \\
\hline
\end{tabular}




\begin{tabular}{|c|c|c|c|c|c|}
\hline Number & Variable & Type & Comments & Units & Meaning \\
\hline$B(190)$ & WED & $\mathbf{F}$ & Default $=0.705 * \mathrm{ft}^{2}$ & watt & $\begin{array}{l}\text { Average Daytime Electric Equipment } \\
\text { For Gas Appliance, Use Electric } \\
\text { Equivalent Value }\end{array}$ \\
\hline$B(191)$ & WEN & $\mathbf{F}$ & Default $=0.424 * \mathrm{ft}^{2}$ & watt & $\begin{array}{l}\text { Average Nighttime Electric } \\
\text { Equipment For Gas Appliance, Use } \\
\text { Electric Equivalent Value }\end{array}$ \\
\hline$B(192)$ & FLOORA & $\mathbf{F}$ & Default $=1200.0$ & $f t^{2}$ & $\begin{array}{l}\text { Floor Area (Flat Projection } \\
\text { of House) }\end{array}$ \\
\hline$B(193)$ & ATFLR & $\mathbf{F}$ & Default $=1200.0$ & $f t^{2}$ & Area of Attic Floor \\
\hline$B(194)$ & UBW & $\mathbf{F}$ & Default $=1.0$ & Btuh & Basement Wall Heat Conductance \\
\hline$B(195)$ & ISYS & I & $\begin{array}{l}1=\text { Heat, No Cool } \\
2=\text { Cool, No Heat } \\
3=\text { Heat + Cool }\end{array}$ & --- & System Index \\
\hline$B(196)$ & UFW & $\mathbf{F}$ & Default $=0.164$ & Btuh & Ground Heat Conductance for Wall \\
\hline$B(197)$ & BWA & $\mathbf{F}$ & & $f t^{2}$ & Basement Wall Area \\
\hline$B(198)$ & UBF & $\mathbf{F}$ & Default $=1.0$ & Btuh & Basement Floor Heat Conductance \\
\hline$B(199)$ & UFF & $\mathbf{F}$ & Default $=0.1$ & Btuh & Ground Heat Conductance for Floor \\
\hline$B(200)$ & QBHG & $\mathbf{F}$ & Default $=0.0$ & Btuh & $\begin{array}{l}\text { Basement Heat Gain From Furnace } \\
\text { and Other Equipment }\end{array}$ \\
\hline$B(201)$ & THTC & $\mathbf{F}$ & $\begin{array}{l}\text { Table on page E-2 } \\
\text { Default }=15.0\end{array}$ & hr & Thermal Time Constant \\
\hline$B(202)$ & ZKS & $\mathbf{F}$ & Default $=1.0$ & Btuh-ft & Ground Thermal Conductivity \\
\hline$B(203)$ & $\mathrm{DX}$ & $F$ & Default $=500$ & ft & Side Distance from Adjacent House \\
\hline$B(204)$ & DY & $\mathbf{F}$ & Default $=500$ & ft & Front to Back Distance from Adjacent House \\
\hline$B(205)$ & $\mathbf{E}$ & $\mathbf{F}$ & Default $=0.5$ & ft & Wall Thickness \\
\hline$B(206-213)$ & & & unused & & \\
\hline$B(214-225)$ & $H(x)$ & $P(12)$ & & $\mathrm{Btu} / \mathrm{day} / \mathrm{ft}^{2}$ & $\begin{array}{l}\text { Total Horizontal Solar } \\
\text { Insolation (Month) }\end{array}$ \\
\hline$B(226)$ & EH & $\mathbf{F}$ & $\begin{array}{l}\text { Value }=\text { F(Fuel EFF, Mod } \\
\text { Factor) }\end{array}$ & -- & Heating Efficiency \\
\hline $8(227-231)$ & $x(16)$ & $F(5)$ & Unused & & \\
\hline
\end{tabular}




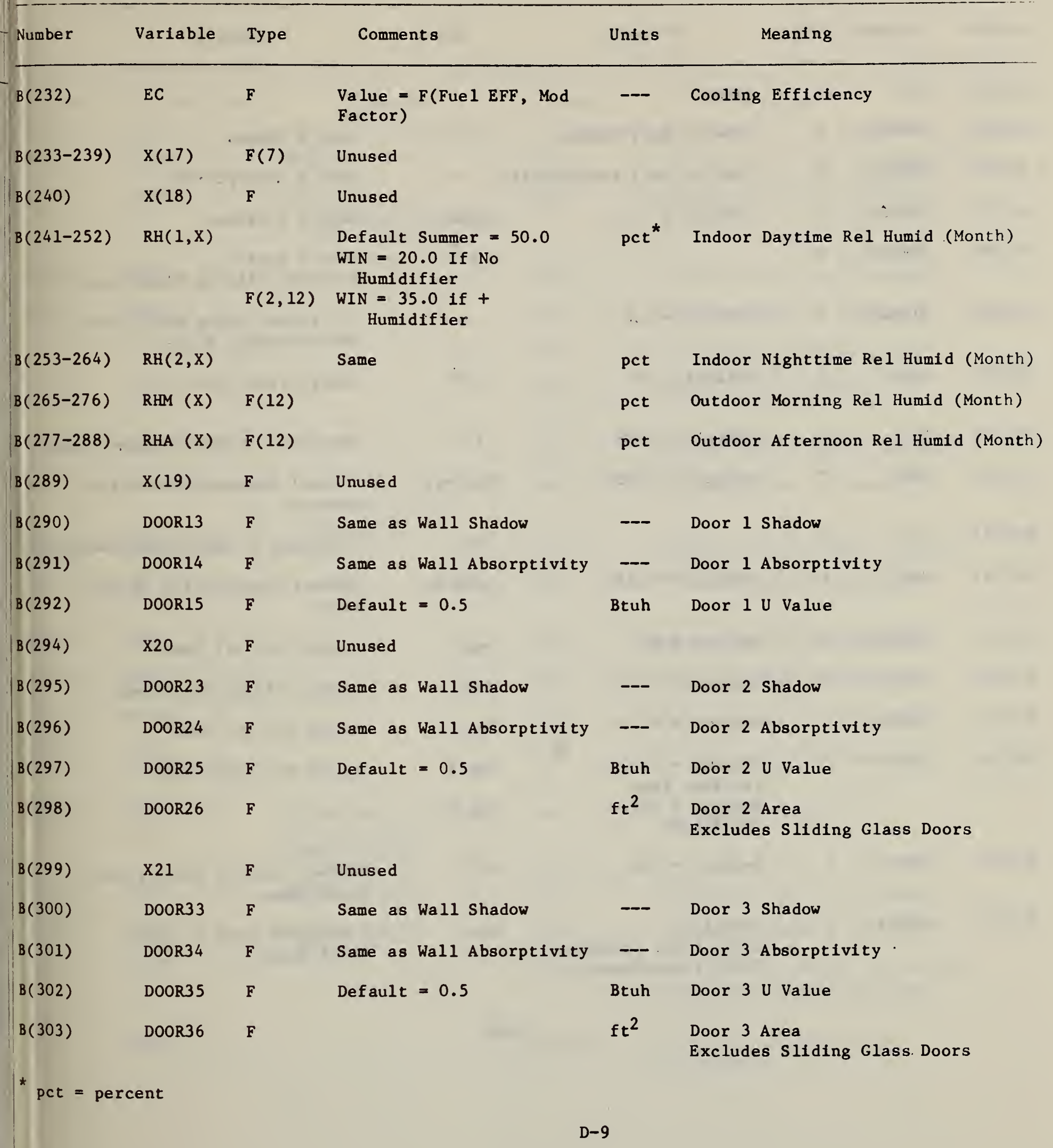




\begin{tabular}{|c|c|c|c|c|c|}
\hline Number & Variable & Type & Comments & Un1ts & Meanting \\
\hline$B(304)$ & $\mathrm{X} 22$ & $\mathbf{F}$ & Unused & & \\
\hline$B(305)$ & DOOR43 & $\mathbf{F}$ & Same as Wall Shadow & -- & Door 4 Shadow \\
\hline$B(306)$ & DOOR44 & $\mathbf{F}$ & Same as Wall Absorptivity & -- & Door 4 Absorptivity \\
\hline$B(307)$ & DOOR45 & $\mathbf{F}$ & Default $=0.5$ & Btuh & Door $4 \mathrm{U}$ Value \\
\hline$B(308)$ & DOOR46 & $\mathrm{F}$ & & $f t^{2}$ & $\begin{array}{l}\text { Door } 4 \text { Area } \\
\text { Excludes Sllding Glass Doors }\end{array}$ \\
\hline$B(309)$ & ICHECK & $\mathbf{F}$ & Default $=0.0$ & - & $\begin{array}{l}\text { = } 1 \text { To Get De bug Output From } \\
\text { Thermodynam1c Model }\end{array}$ \\
\hline$B(310)$ & AJAC & $\mathbf{F}$ & Default $=40$ & $f t^{2}$ & Total Jacket Area \\
\hline$B(311)$ & D1 & $\mathbf{F}$ & Default $=0.08$ & ft & Thickness of Existing Insulation \\
\hline$B(312)$ & RAMl & $F$ & Default $=0.025$ & Btuh-ft & $\begin{array}{l}\text { Thermal Conductivity of the } \\
\text { Above }\end{array}$ \\
\hline$B(313)$ & D2 & $\mathbf{F}$ & & ft & Th1 ckness of Additional Insulation \\
\hline$B(314)$ & RAM2 & F & Default $=0.025$ & Btuh-ft & $\begin{array}{l}\text { Thermal Conductivity of the } \\
\text { Above }\end{array}$ \\
\hline$B(315)$ & TCSUPA & $\mathbf{F}$ & Default $=62$ & $\operatorname{deg} F$ & Supply Cold Air Temp. \\
\hline$B(316)$ & TCSUPW & F & Default $=41.0$ & $\operatorname{deg} F$ & Supply Chilled Water Temp. \\
\hline$B(317)$ & THSUPA & $\mathbf{F}$ & Default $=95.0$ & $\operatorname{deg} F$ & Supply Hot Alr Temp. \\
\hline$B(318)$ & THSUPW & $\mathbf{P}$ & $\begin{array}{l}\text { Default }=113.0 \\
\text { for Heat Pump } \\
\text { Default }=176.0 \\
\text { for Boller }\end{array}$ & $\begin{array}{l}\operatorname{deg} F \\
\operatorname{deg} F\end{array}$ & Supply Hot Water Temp. \\
\hline$B(319)$ & ADUCT I & $\mathbf{F}$ & Default $=100$ & $f t^{2}$ & $\begin{array}{l}\text { Surface Area of Duct in the } \\
\text { Crawl Space }\end{array}$ \\
\hline$B(320)$ & UDUCT1 & $F$ & $\begin{array}{l}\text { Default }= \\
1.46 \text { If Not Insulated } \\
0.15 \text { If Insulated }\end{array}$ & Btuh & $\begin{array}{l}\text { U Value of Duct in the } \\
\text { Crawl Space }\end{array}$ \\
\hline
\end{tabular}




\begin{tabular}{|c|c|c|c|c|c|}
\hline Number & Variable & Type & Comments & Units & Meaning \\
\hline$B(321)$ & APIPE1 & $\mathbf{F}$ & Default $=1.5$ & $\mathrm{ft}^{2}$ & Surface Area of Pipe in Crawl Space \\
\hline$B(322)$ & UPIPE1 & $\mathbf{F}$ & $\begin{array}{l}\text { Default = } \\
1.46 \text { If Not Insulated } \\
0.15 \text { If Insulated }\end{array}$ & Btuh & U Value of P1pe In Crawl Space \\
\hline$B(323)$ & ADUCT 2 & $\mathbf{F}$ & & $\mathrm{ft}^{2}$ & Surface Area of Duct in Attic \\
\hline$B(324)$ & UDUCT2 & $\mathbf{F}$ & & Btuh & U Value of Duct In Attic \\
\hline & & & & $f t^{2}$ & Surface Area of Pipe in Attic \\
\hline$B(326)$ & UPIPE2 & $\mathbf{F}$ & & Btuh, & U Value of Duct in Attic \\
\hline$B(327)$ & ADUCT 3 & $\mathbf{F}$ & & $f t^{2}$ & Surface Area of Duct in Basement \\
\hline$B(328)$ & UDUCT3 & $\mathbf{F}$ & Same as the Craw 1 & Btuh & U Value of Duct in Basement \\
\hline$B(329)$ & APIPE3 & $\mathbf{F}$ & Space & $\mathrm{ft}^{2}$ & Surface Area of Pipe in Basement \\
\hline$B(330)$ & UPIPE3 & $\mathbf{F}$ & & Btuh & U Value of Pipe in Basement \\
\hline$B(331)$ & ADUCT4 & $\mathbf{F}$ & & $f t^{2}$ & Surface Area of Outdoor Duct \\
\hline$B(332)$ & UDUCT4 & $\mathbf{F}$ & & Btuh & U Value of Duct Outdoors \\
\hline$B(333)$ & APIPE4 & $\mathbf{F}$ & & $f t^{2}$ & Surface Area of Outdoor Pipe \\
\hline$B(334)$ & UPIPE 4 & $\mathbf{F}$ & & Btuh & U Value of Pipe Outdoors \\
\hline$B(335)$ & AIRLOS & $\mathbf{F}$ & $\begin{array}{l}\text { Percentage To Total } \\
\text { Air Flow Rate; } \\
\text { Default }=10.0\end{array}$ & pct & Air Leakage Through Duct \\
\hline$B(336)$ & CAPCL & $\mathbf{F}$ & Default $=24000$ & $\mathrm{Btu} / \mathrm{h}$ & Capacity of Cooling Equipment \\
\hline$B(337)$ & CAPHT & $\mathbf{F}$ & Default $=64000$ & $\mathrm{Btu} / \mathrm{h}$ & Capacity of Heating Equipment \\
\hline $\mathrm{R}(1)$ & SHBTU & $F$ & & Btu/yr & $\begin{array}{l}\text { Annual Heating Energy Requirement } \\
\text { After Using Energy From Solar } \\
\text { Collector }\end{array}$ \\
\hline$R(2)$ & SCBTU & $\mathbf{F}$ & & Btu/yr & $\begin{array}{l}\text { Annual Space Cooling Energy } \\
\text { Requirement }\end{array}$ \\
\hline
\end{tabular}





\section{APPENDIX E}

\section{Thermal Time Constant and Its Application}

The thermal time constant of a building is a parameter to indicate the speed of indoor temperature response to a sudden change of building heating and cooling operation. The heavier the thermal mass of a building, the slower its response, compared to a lighter building, to cool down or heat up when the building heating system is turned off and on, respectively. The thermal time constant is defined as a ratio between the equivalent thermal mass of the building and the building overall heat transfer factor. Whereas the overall heat transfer factor may be approximated by the heat transfer coefficients, U value, multiplied by the areas, A, of all the elements, such as walls, doors, windows, roof and floors, and the air leakage rate multiplied by the specific heat of air, the equivalent building thermal mass is rather difficult to ascertain. The building mass is distributed in a complex manner, with respect to its size and shape, position in the insulated structure, and floor interface with the earth.

Although difficult to calculate, the overall building thermal time constant can readily be determined by a simple cool-down test during a heating season based upon the following mathematical relationship.

When the heating system and all the heat sources in a house are suddenly shut off during a steady cold night (outdoor temperature of To), its temperature would decay from the initial setpoint of $\mathrm{T}_{1}$ according to the following equation:

$$
M C * \frac{d T}{d H}=-K^{*}(T-T o)
$$

where

$$
\begin{aligned}
\mathrm{MC} & =\text { overall thermal mass, } \mathrm{Btu} /{ }^{\circ} \mathrm{F} \\
\mathrm{K} & =\text { overall heat transfer factor, Btu/hr, }{ }^{\circ} \mathrm{F} \\
\mathrm{H} & =\text { hour }
\end{aligned}
$$

The thermal time constant, THTC, is defined as

$$
\text { THTC }=\frac{M C}{K} \text {, in the unit of hour }
$$

The differential equation $\mathrm{E}-(1)$ becomes then

$$
\frac{\mathrm{dT}}{\mathrm{T}-\mathrm{To}}=-\frac{\mathrm{dH}}{\mathrm{THTC}} \text {, }
$$


which has a following solution:

$$
\text { THTC }=\frac{H}{\ln \left(\frac{T_{i}-T_{0}}{T-T_{0}}\right)}
$$

Thus by measuring a logarithmic decay of the building temperature, from initial value of $\mathrm{T}_{1}$ to $\mathrm{T}$ during a time span of $\mathrm{H}$ hours, one can readily calculate the value of the thermal time constant.

According to Nash's datal/, typical THTC for residences are:

\begin{tabular}{cccc} 
& $\begin{array}{l}\text { Light } \\
\text { Weight }\end{array}$ & $\begin{array}{c}\text { Medium } \\
\text { Weight }\end{array}$ & $\begin{array}{l}\text { Heavy } \\
\text { Weight }\end{array}$ \\
\hline $\begin{array}{c}\text { One-story } \\
\text { house }\end{array}$ & 10 & 15 & 20 \\
\hline $\begin{array}{c}\text { Two-story } \\
\text { house }\end{array}$ & 30 & 35 & 40 \\
\hline
\end{tabular}

When a building heat transfer process is simulated by a simple thermal capacity model, its temperature change may similarly be represented by the following first order differential equation

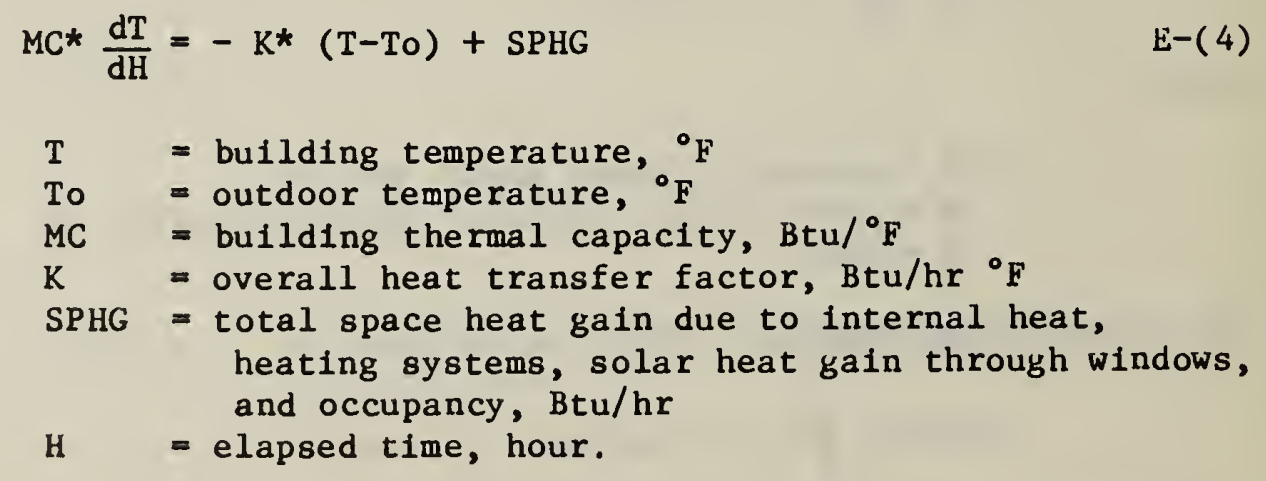


General solution to the above equation is

where

$$
\frac{\mathrm{Q}-\mathrm{T}_{1}+\mathrm{To}_{0}}{\mathrm{Q}-\mathrm{T}+\mathrm{To}}=\mathrm{e}^{\frac{\mathrm{H}}{\mathrm{THTC}}}
$$

$$
\begin{aligned}
\mathrm{Q} & =\frac{\mathrm{SPHG}}{\mathrm{K}}=\text { heat source constant, }{ }^{\circ} \mathrm{F} \\
\text { THTC } & =\frac{\mathrm{MC}}{\mathrm{K}}=\text { thermal time constant, } \mathrm{hr} \\
\mathrm{T}_{1} & =\text { value of } \mathrm{T} \text { when } \mathrm{H}=0,{ }^{\circ} \mathrm{F} .
\end{aligned}
$$

Equation E-(5) permits, for example, the determination of the duration, $\mathrm{DH}$, for which the house temperature reaches from the daytime set point TID to the nighttime set point TIN, which is usually lower.

Since $Q$ is very small during that period, referring to Figure E-(1),

$$
\mathrm{DH}=\mathrm{THTC}^{*} \ell \mathrm{n}\left[\frac{\mathrm{TID}-\mathrm{TON}}{\mathrm{TIN}-\mathrm{TON}}\right]
$$

Likewise equation $\mathrm{E}-(5)$ may be used to determine the early morning pickup heating load (or the early evening pull-down cooling load), MPUL, by specifying the required temperature recovery time or pick-up time, PUH, (or pull down time, PHD) as follows

$$
\frac{\frac{\text { MPUL }}{\mathrm{K}}-\mathrm{TIN}+\text { TOD }}{\frac{\text { MPUL }}{\mathrm{K}}-\mathrm{TID}+\mathrm{TOD}}=\mathrm{e}^{\frac{\mathrm{PUH}}{\mathrm{THTC}}}
$$

By rearranging the term, MPUL can be determined by

$$
\text { MPUL } \left.=K^{*}[\text { (TIN-TOD })+\frac{\text { TID-TIN }}{1-e^{-P U H / T H T C}}\right]
$$

Another example of the use of THTC is to approximate the benefit of excess solar heat gain during a sunny winter day to offset the heat loss during the night.

The procedure used is first to determine the indoor temperature rise Tk, due to the excess heat gain, above the daytime indoor temperature setpoint TID by the following equation 

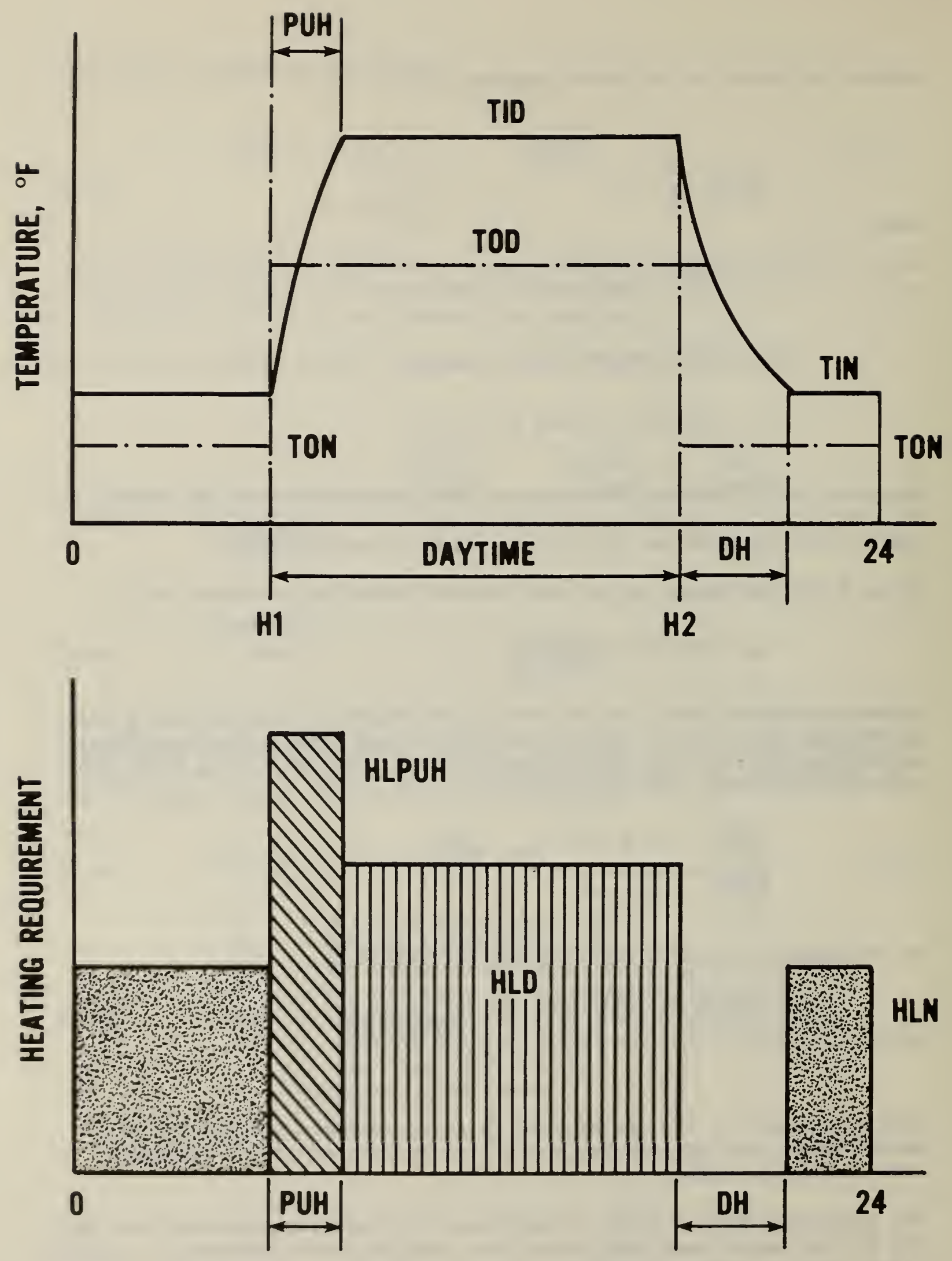

E1gure E-1. Temperature and heating requirement profile during the nighttime thermostat setback. 


$$
\mathrm{TR}=\frac{\mathrm{QTD}}{\mathrm{K}^{*} 12} *\left[1-\mathrm{e}^{\frac{-\left(\mathrm{H}_{2}-\mathrm{H}_{1}\right)}{\mathrm{THTC}}}\right]
$$

where QTD is the excess daytime heat gain during hour from $\mathrm{H}_{1}$ to $\mathrm{H}_{2}$, which is the balance of heat gain above what is required to cancel. the envelope heat loss.

The equation E-(6) will now be used to determine the "off" period of the heating system except that TID in equation (6) is now replaced by the new starting temperature TID + TR.

A similar concept may be used to determine the effect of night heat loss during the cooling season to offset the daytime cooling requirement as follows:

The temperature drop of the room air from the set point of TIN during the cool night due to the excess heat loss QTN is

$$
\mathrm{TD}=\frac{\mathrm{QTN}}{\mathrm{K} * 12} *\left(1-\mathrm{e}^{-\frac{\mathrm{HN}}{\mathrm{THTC}}}\right)
$$

where HN is the nighttime hours

The period when the air-conditioning system could be off due to this night cooling is then

$$
\mathrm{DH}=\mathrm{THTC} * \ln \left(\frac{\frac{\mathrm{QTD}}{\mathrm{K} * 12}-\mathrm{TIN}+\mathrm{TD}+\mathrm{TOD}}{\frac{\mathrm{QTD}}{\mathrm{K} * 12}-\mathrm{TID}+\mathrm{TOD}}\right)
$$

provided that $(T I N-T D)<T I D$.

Figure E-2 depicts indoor temperatures, cooling and heating periods, and other notations such as $\mathrm{DH}, \mathrm{PDH}, \mathrm{PUH}$ and TD in cooling season. Figure $\mathrm{E}-2$ (a) shows indoor temperatures and cooling period in a day when QTD $\geq 0$ and QTN $\geq 0$. The daytime indoor temperature rises from TIN to TID during early morning pickup hours, DH, while the cooling system is turned off. After this period, the temperature is maintained at TID during daytime, followed by a pull down to TID at the beginning of nighttime for a period of PHD hours. The cooling system is, therefore, assumed to be running all day except for the period of $\mathrm{DH}$.

Figure E-2(b) shows the case of QTV $\geq 0$ and QTN $\geq 0$. In this case, the nighttime indoor temperature decreases from TIN to TIN-TD according to the nighttime heat losses, while the cooling system is turned on during a period of $\mathrm{PDH}$. Because of the night heat loss the indoor temperature 
is lower than TIN by TU at the beginning of daytime. Uuring an early morning period of $\mathrm{DH}$, the temperature naturally rises to TIV because of the daytime heat gains. Consequently, the cooling system continues to operate throughout the day except periods $\mathrm{DH}$ and PDH.

There is a limitation on input of daytime and nighttime indoor temperatures, TID and TIN, in that TID is always equal to or higher than I'IN. The reason of this limitation is to avoid algorithmic complexities.

Figures E-2(c) and (d) depict indoor temperatures profile during the heating period.

Figure $E-2(c)$ shows indoor temperatures and heating period in a day when $\mathrm{QTD}>0$ and $\mathrm{QTN} \leq 0$. The daytime indoor temperature goes up to TID $+\mathrm{TD}$ at the end of daytime because the cooling system is not running in spite of QTD > 0 during the daytime. The nighttime indoor temperature goes down from TID + TR to TIN during a period of $\mathrm{PH}$ because QTN $\leq 0$ and the heating system is turned off. After the temperature reached to IIN, the heating system is turned on.

Figure E-2(d) shows indoor temperatures and heating period in a day when QTD $\leq 0$ and $\mathrm{QTN} \leq 0$. The nighttime indoor temperature decreases to TIN from TID because of night setback. during a period of DH, the heating system is turned off. PUH is pick-up time, during which the indoor temperature goes up to TID from TIN because of the heating system.

If there is a case of QTD $\leq 0$ and QTN $\geq 0$, it is neglected, meaning that the heating and cooling requirements should be equal to zero because the case should seldom occur in the cooling season.

The heating and cooling requirement are both set equal to zero during the heating season when the daytime and nighttime heat balance, QTU and QTN, are both positive. Likewise QTD and QTN are both set equal to zero during the cooling season if QTD and QTN are both negative. 


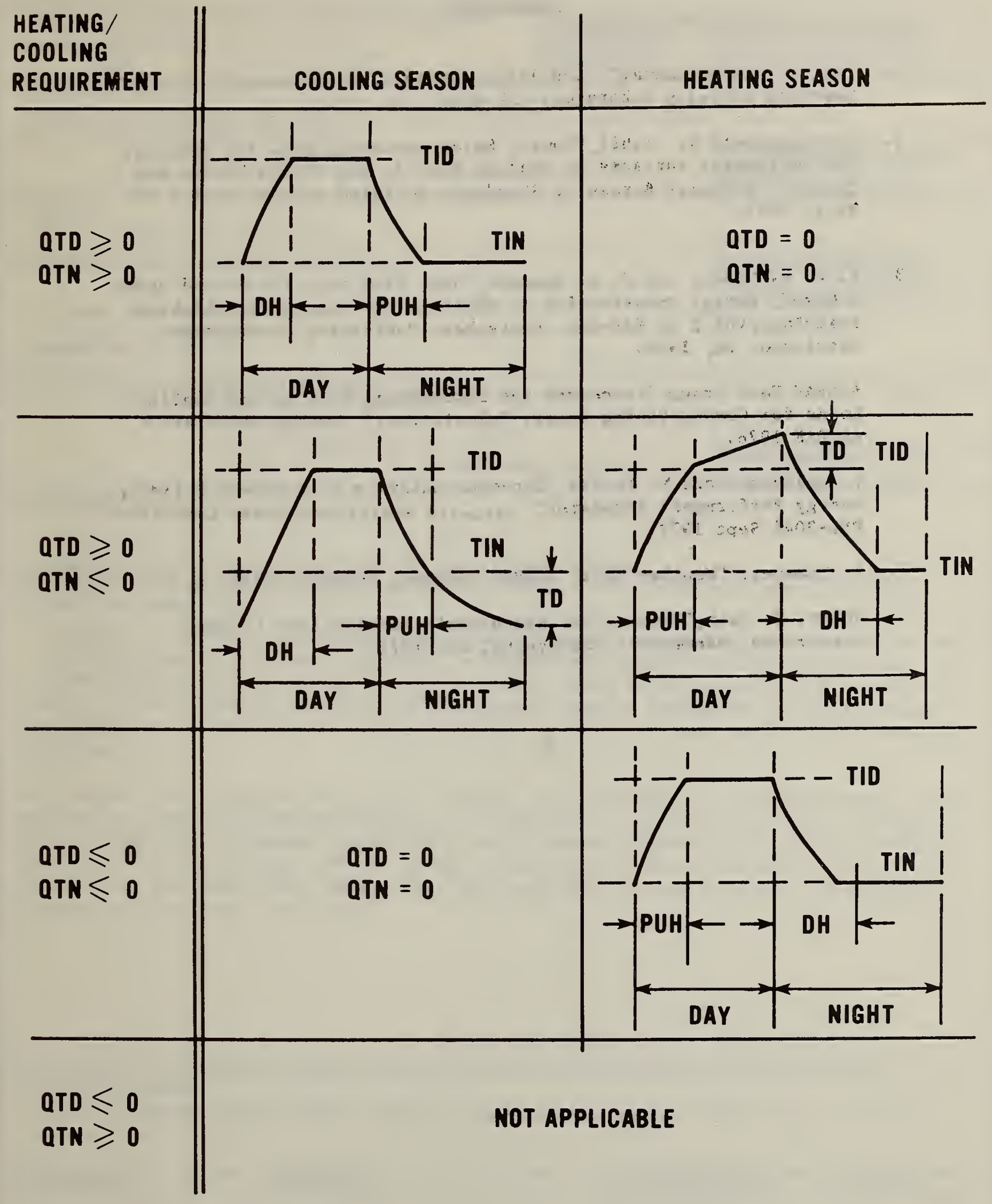

Figure E-2. Temperature profiles for various modes of heating and cooling operations. 
1. "DOE-2 Program Manual," Los Alamos Scientific Laboratory LA-7688-17, and Lawrence Berkeley Laboratory LBL-8705, Feb 1979.

2. T. Kusuda and K. Ish11, "Hourly Solar Radiation Data for Vertical and Horizontal Surfaces on Average Days in the United States and Canada" National Bureau of Standards Building Science Series 96, Apri1 1977.

3. R. W. R. Muncey and J.W. Spencer, "Heat Flow into the Ground under a Home". Energy Conservation in Heating, Cooling and Ventilating Buildings, Vol 2 pp 649-660. Hemisphere Publishing Corporation Washington DC, 1978 .

4. ASHRAE Task Group "Procedure for Determining Heating and Cooling Loads for Computerizing Energy Calculations" Energy Calculation 1 ASHRAE 1976.

5. D. Goldstein and M. Levine, "Economic Analysis of Proposed Building Energy Performance Standards" Battelle Pacific Northwest Laboratory PNL-3044 Sept 1979.

6. E. Stamper, "Weather Data" ASHRAE Journal, February 1977, p. 47.

7. Robert T. Nash, "Thermal and Hygroscopic Fluctuations in Small Structures": Vanderb11t Univers1ty, Dec 1975. 
NBS-IIAA IREV. 0.78)

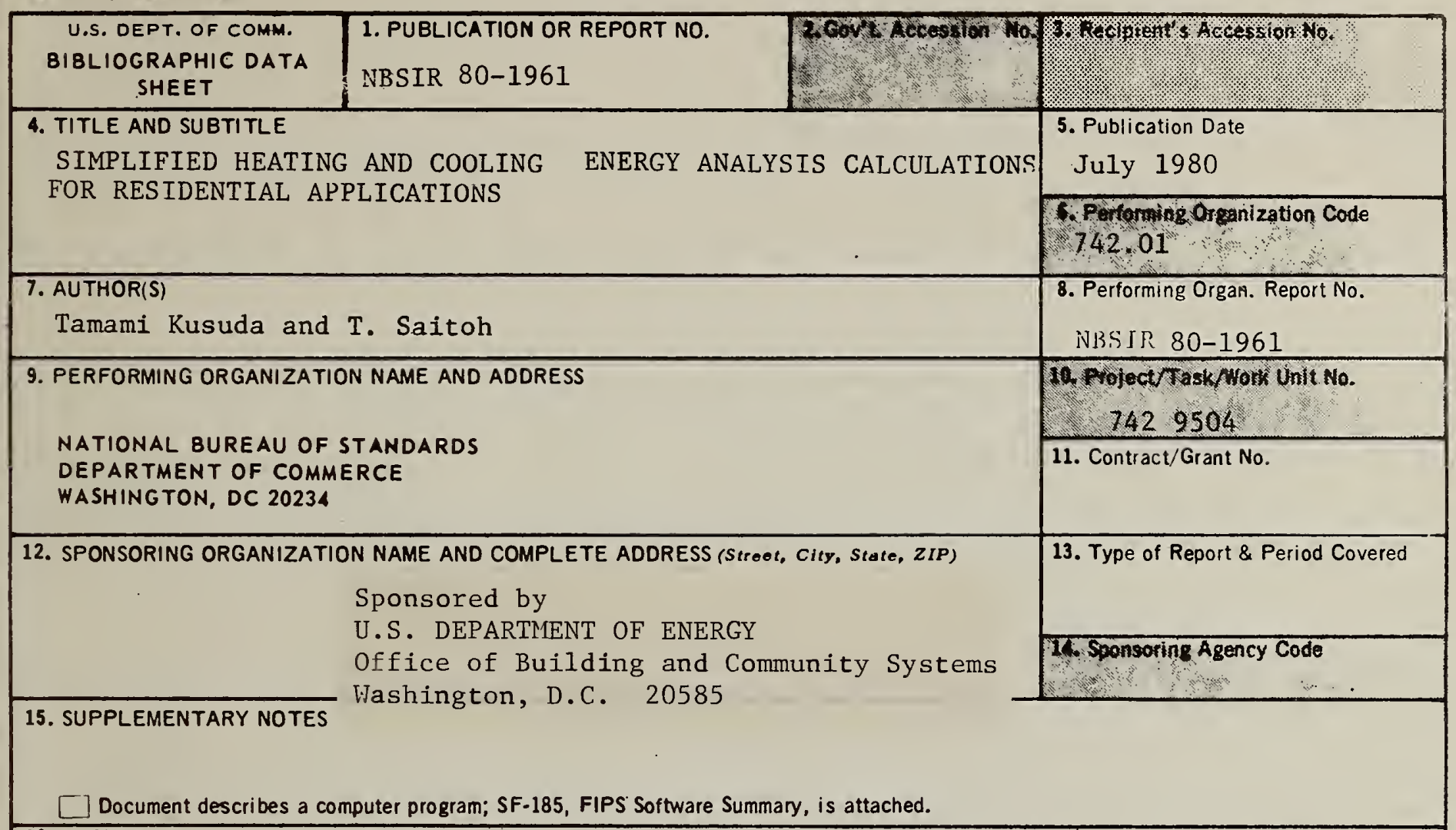

16. ABSTRACT (A 200-word or less fectual summary of most aignificant information. If document includes a significant bibliography or literature survey, mention it here.)

In order to shorten the lengthy computational labor and cost common to most existing hourly simulation computer programs, a simplified energy calculation procedure was developed for the evaluation of energy conservation effectiveness of home retrofitting. The procedure utilizes monthly normal weather parameters such as temperature, humidity, wind data, and solar radiation, in lieu of the traditional cegree-day procedure.

The thermal time constant was used to account for the effect of building thermal mass on seasonal heat transfer performance. In addition to standard retrofit procedures such as addition of thermal insulation, use of storm windows, and sealing of cracks, included in the procedure are the energy conservation effects due to the use of solar collectors, hot water tank insulation, and insulation around the heat distribution systems such as ducts and pipes.

17. KEY WORDS (six to twolve ontrien; alphabetical order; capitalixe only the firet lotter of the first key word unless a proper name; separated by amicolons)

Energy analysis calculation; energy retrofit; home audit; thermal time constant.
18. AVAILABILITY
X. Unlimited

For Official Distribution. Do flot Release to NTIS

] Order From Sup. of Doc., U.S. Government Printing Office, Wasinington, DC 20402, SD Stock No. SNO03-003-

[X] Order From National Technical Information Service (NTIS), Springfield, VA. 22161

\begin{tabular}{|c|c|}
\hline $\begin{array}{l}\text { 19. SECURITY CLASS } \\
\text { (THIS REPORT) }\end{array}$ & $\begin{array}{l}\text { 21. NO. OF } \\
\text { PRINTED PAGES }\end{array}$ \\
\hline UNCLASSIFIED & 135 \\
\hline $\begin{array}{l}\text { 20. SECURITY CLASS } \\
\text { (THIS PAGE) }\end{array}$ & 22. Price \\
\hline UNCLASSIFIED & $\$ 10.00$ \\
\hline
\end{tabular}




